\title{
OVER-THE-ROAD TESTS OF NUCLEAR MATERIALS PACKAGE RESPONSE TO NORMAL ENVIRONMENTS
}

\author{
K. W. Gwinn \\ Applied Mechanics Division 1544
}

R. E. Glass

Transportation System Technology Division 6322

K. R. Edwards

Transportation System Development Division 6323

Sandia National Laboratories

Albuqusrque, New Mexico

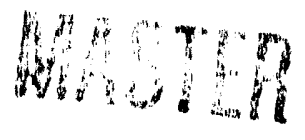


TTC- 1072

SAND91-0079

Unlimited Release

OVER-THE-KOAD TESTS OF NOCLEAR MATERIALS
PACKAGE RESPONSE TO NORKAL ENVTROMERTS*

\author{
K. W. Gwinn \\ Applied Mechanics Division 1544 \\ R. E. Glass \\ Transportation System Technology DIvision 6322 \\ K. R. Edwards \\ 'rransportation System Development Division 6323 \\ Sandla National Laboratorles** \\ Albuquerque, New Mexico 87185
}

\begin{abstract}
In support of the development of Amexican Wational Standards Institute standards for the transport of radloactive materials, Sandia has a program to characterize the normal transport environment. This program includes both analytical modeling of package and trailer responses, and over-the road tests to asure those responses. This paper presents the results of a series of over-the-rosd tests performed using Chem-Nuclear equipment in the Barnwell, SC, area.

The test events included a varfety of road types such as rough concrete, shock events such as rallroad grade crossings, and driver responses such as sharp tirns. The response of the package and trailer to these events was measured with acceleromaters at various locations to determine the inertial loads. Elther load cells or strain gages were used to measur tledown response. These accelerations and loads were measured on systems with flexlble and "rigid" tledowns.

The results indicated that while significant accelerations occur on the trafler bed, these do not translate into equivalent loads in either the package 01 the tledown system. This indicates that trailer-bed response should not be used in determining the load factor for fatigue calculations of the package components or in determining design loads for tiedowns.
\end{abstract}

*This work performed at Sandia National Laboratories, Albuquerque, New Mexico, supported by the U.S. Department of Fnergy under contract DE-ACO476 DP00789.

**A United States Department of Energy facility. 


\section{Acknowledgment}

The authors would like to thank Burl G. Fauchier of Chem*Nucleax Systems, Inc., for his assistance in performing these tests, and James W. Doggett of Sandia's Experimental Mechanics Division III for providing and operating the data acquisition system. . 


\section{Contents}

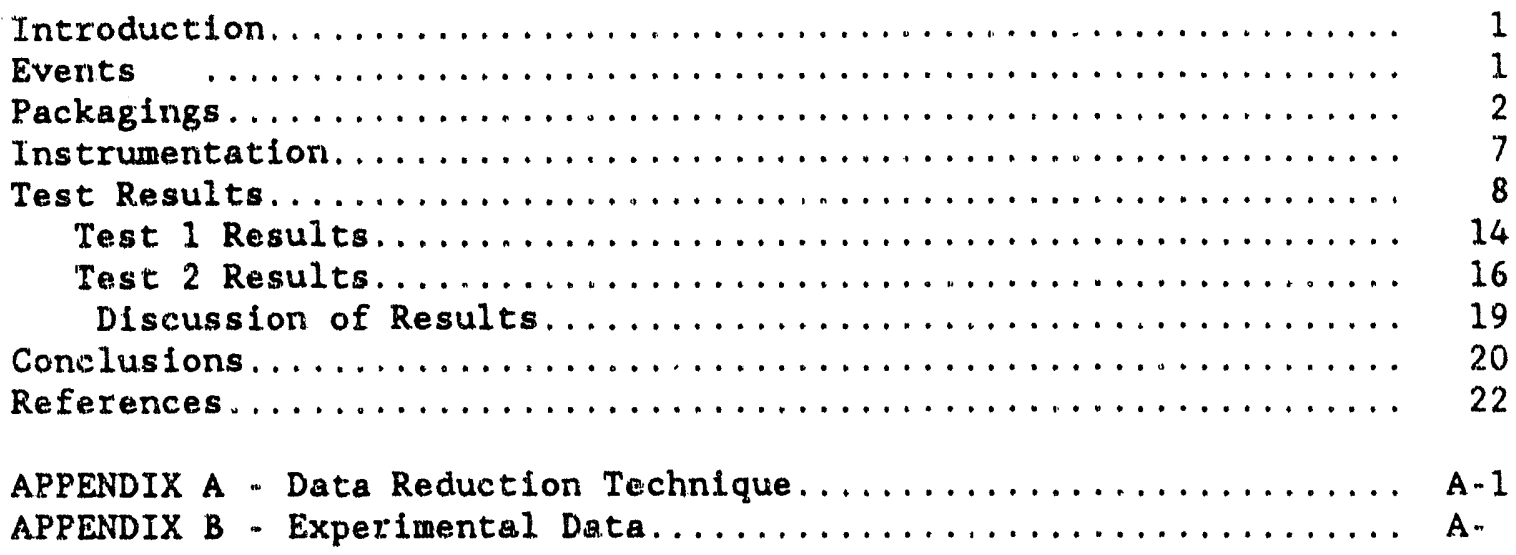

\section{Flgures}

1 Smooth Asphalt Primary Road......................

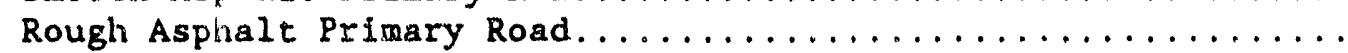

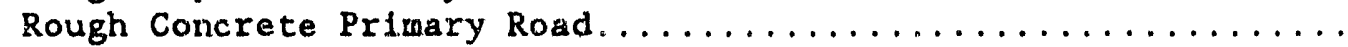

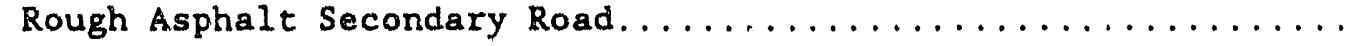

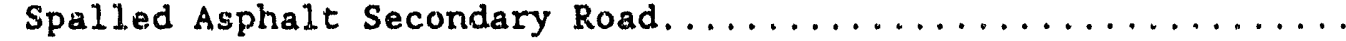

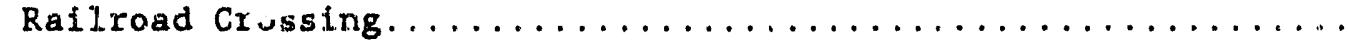

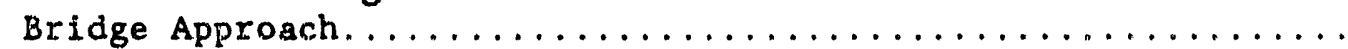

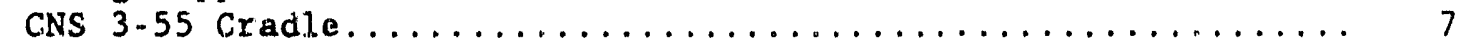

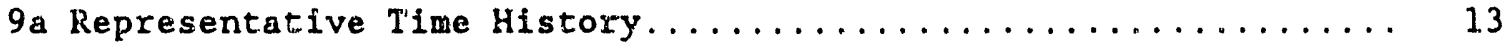

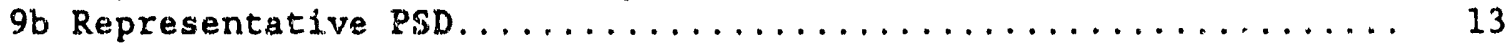

\section{Tables}

I Events.................................. 2

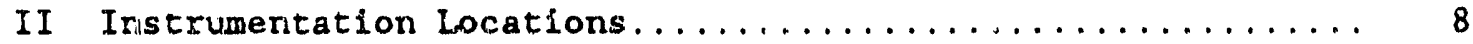

III Peak Accelerations for Shock and vibration Events,........ 9

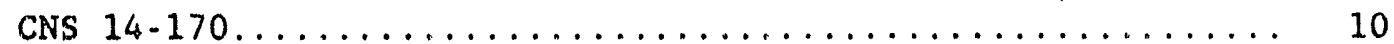

IV RMS Accelerations for Vibration Events, CNS $14-170 \ldots \ldots \ldots 10$

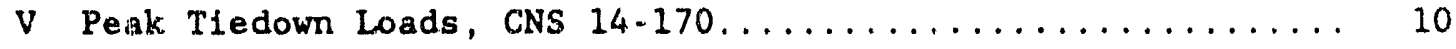

VI Peak Accelerations for Shock and Vibration Events, CNS $3-55 \ldots \ldots \ldots \ldots \ldots \ldots \ldots \ldots \ldots \ldots$

VII RMS Accelerations for Vibration Events, CNS $3-55 \ldots \ldots \ldots \ldots$

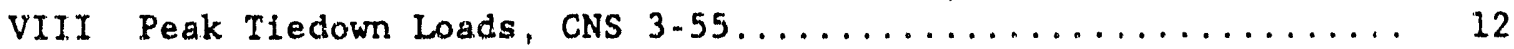

IX. Event Dependence of Vertical Accelerometer Response with Respect to Rall Crossing Response.................. 21

X Spatial Dependence of Vertical Accelerometer Response Normalized with Respect to the Trailer Bed Front Response... 21 
This page intentionally left blank 


\section{Introduction}

Sandia Natfonal Laboratories has an ongoing program to characterize the normal environments encountered during the transport of radioactive materials. This effort consists of obtaining experimental data from both road simulator and over-the-road tests and of analyzing the data to obtain numerical models to simulate those environments (1-3).

Following discussions with the Nuclear Regulatory Agency, further test activities were added to the completed tests (1-3). These included: over-the-road testing with a system incorporating a rigid tiedown system (CNS 3-55), (2) hard braking, and (3) hard turning. The results of these rigid tiedown system tests agreed with these previous test results, in that al1 tiedown loads were well below design limits established in draft ANSI standards and by the Department of Transportation. Package response during any given test is specific to that package and trailer. Based on the full range of over-the-road tests, road simulator tests, and analyses, the current tests provide additional data to support the response envelopes previously presented (3).

These data and models are currently being used in definirg the design basis for resistance to shock and vibration and in defining the requirements for tiedowns for truck transported radioactive materials. This work is in confunction with the American National Standards Institute development of national standards.

This report provides the data from a series of over"the-road tests performed with Chem-Nuclear Systems, Inc equipment near Barnwell, South Carolina. The data include responses of the packaging to driving over varlous road types as well as measurements of the response of the packaging and trailer to hard braking and turning events. The data include the responses of both flexible and rigid tiedown systems. The results indicate that the forces in tledowns for these tests were less than $0.05 \mathrm{~g}$ based on package weight.

\section{Events}

The trailer and packagings were subjected to nine separate events to determine both the acceleration and tiedown loads experienced during normal transport. These are summarized in Table 1. Five types of roads were used: (1) smooth asphalt primary (Figure 1); (2) rough asphalt primary (Figure 2); (3) rough concrete primary (Figure 3); (4) rough asphalt secondary (Figure 4); and (5) spalled asphalt secondary (Figure 5). The roads provided a vibrational environment for the packaging. To subject the packaging to a shock environment, a railroad crossing (Figure 6) and bridge approach (Figure 7) were selected. Finally, to determine the package's response to maneuvering, a hard turn and a stop were executed.

The speed driven for each event was the lesser of either the posted legal speed limit or the fastest speed consistent with safe operation of the tractor. 
For each event, approximately 15 seconds of data were recorded. This provides 15,000 samples per data channel. This is adequate time, as can be seen in the data in the Appendices, to capture shock events, such as the rail crossing plus damping back to the random vibration state. For the random vibration events, such as smooth asphalt roads, it provides a representative sampling. This is demonstrated in the frequency content of the packaging where the lowest fxequency response is between 1 and $2 \mathrm{~Hz}$, so that a 15 second record captures 15 to 30 response cycles.

\section{Packagings}

Two packagings were tested: the CNS $14-170$ and the CNS 3-55, selected on the basis of weight and tiedown type.

The CNS 14-170 is a lead and steel. Type A package used to ship dewatered or solidified waste material, and has an empty package weight of 33,800 lbs. with a payload weight of 14,000 lbs. The package is transported vertically and has a flexible tiedown system.

Table 1: Events

\begin{tabular}{cll} 
Event & Primary Load Type & \multicolumn{1}{c}{ Description } \\
1 & Vibration & Smooth Asphalt Primary \\
2 & Shock & Railroad Grade Crossing \\
3 & Vibration & Rough Asphalt Primary \\
4 & Shock & Bridge Approach \\
5 & Vibration & Rough Concrete Primary \\
6 & Rigid Body & Turn \\
7 & Rigid Body & Stop \\
8 & Vibration & Rough Asphalt Secondary \\
9 & Vibration & Spalled Asphalt Secondary
\end{tabular}

The CNS 3-55 is a steel-encased lead-shielded Type package. The empty package weight is 56,912 lbs. with a payload capacilis of 9,220 lbs. The package is transported horizontally in the cradle replesentative of "rigid" tiedown systems (Figure 8 ). 


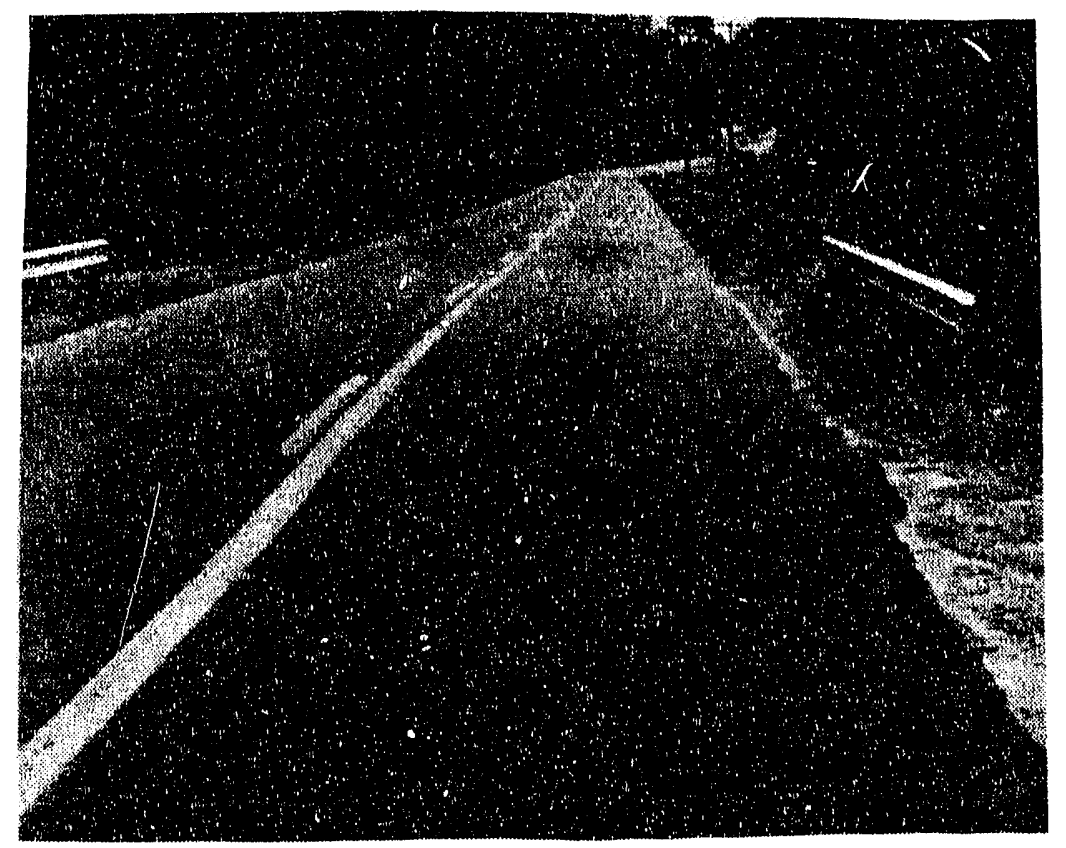

Figure 1. Smooth Asphalt Primary Road

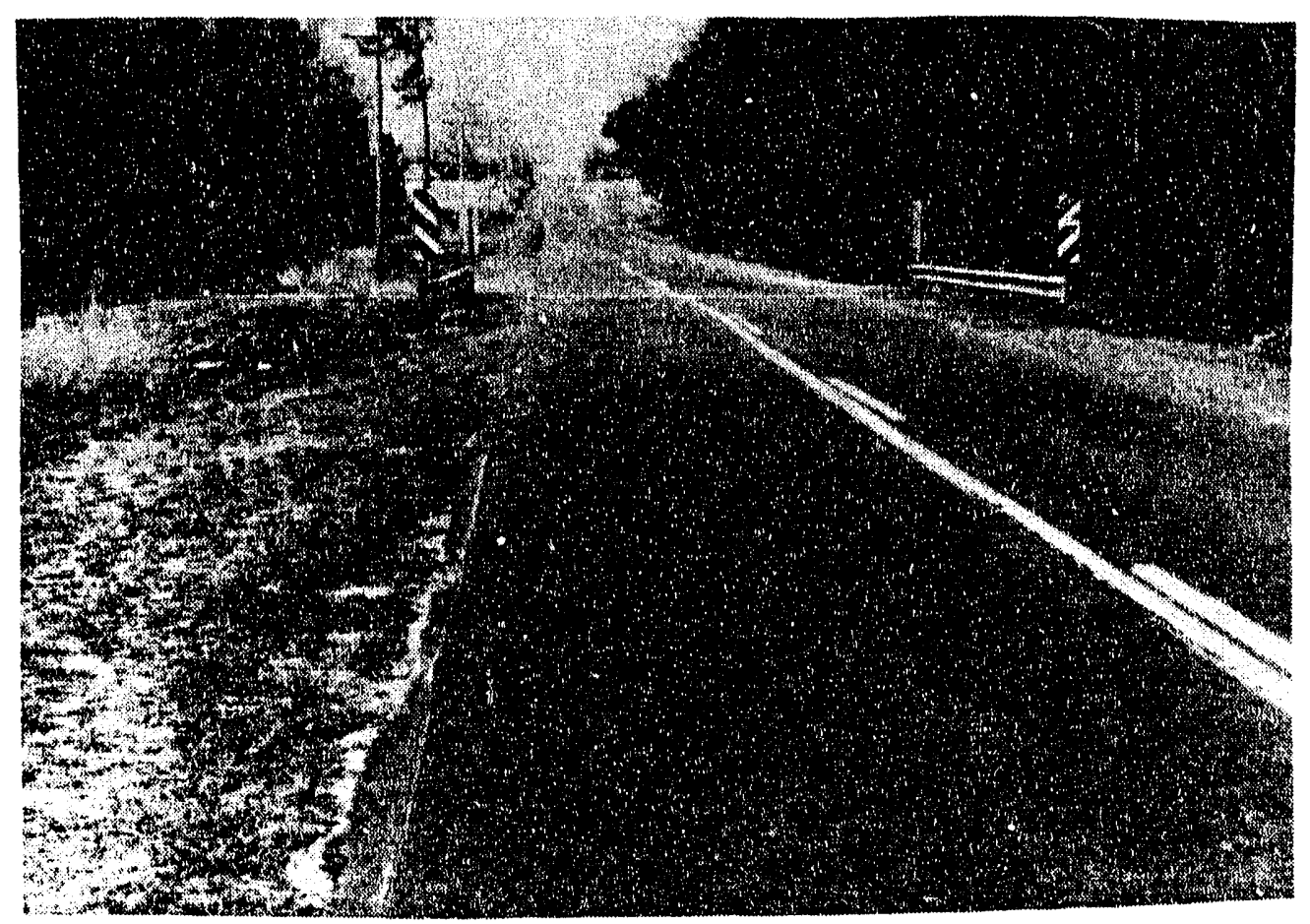

Figure 2. Rough Asphalt Primary Road 


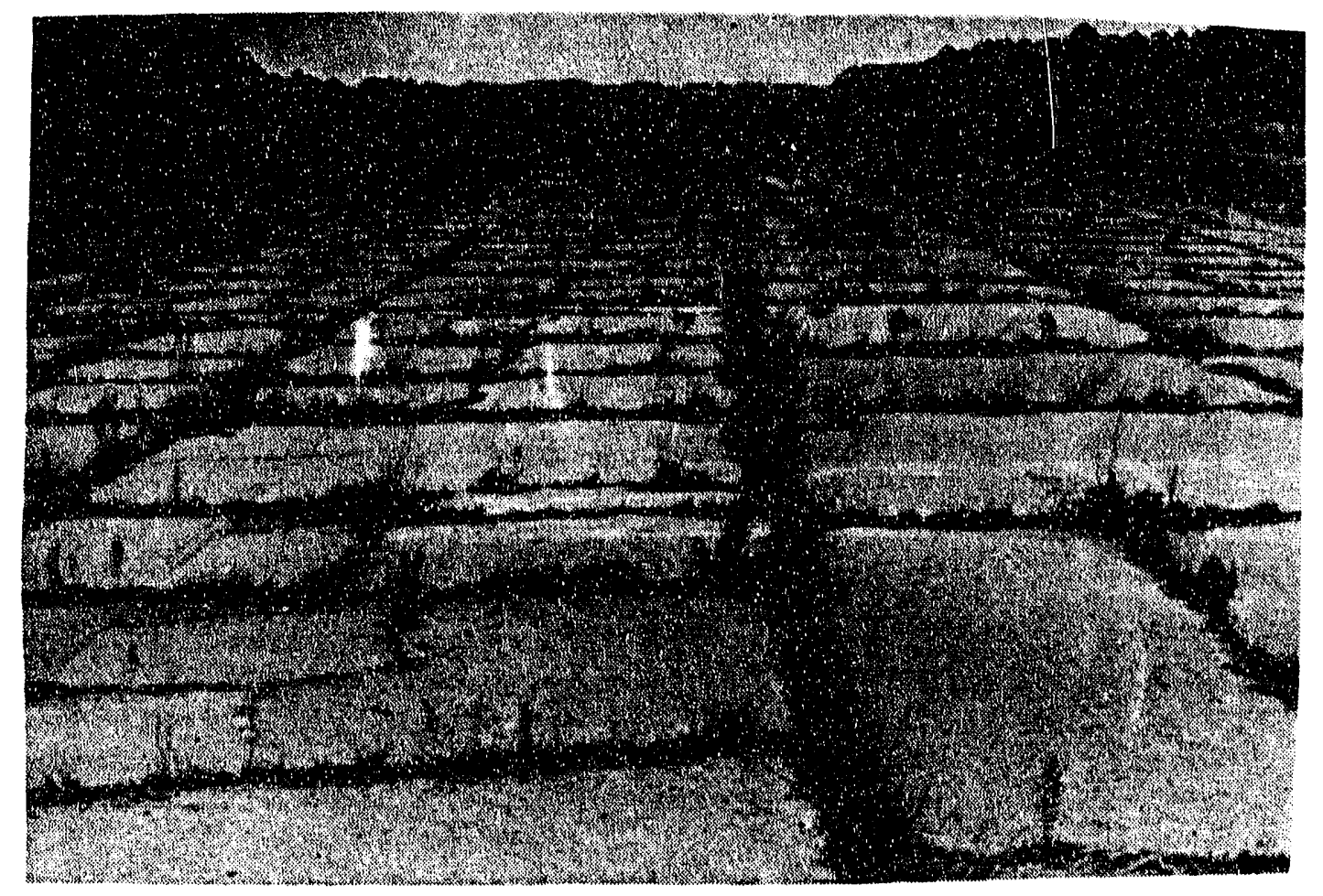

Figure 3. Rough Concrete Primary Road

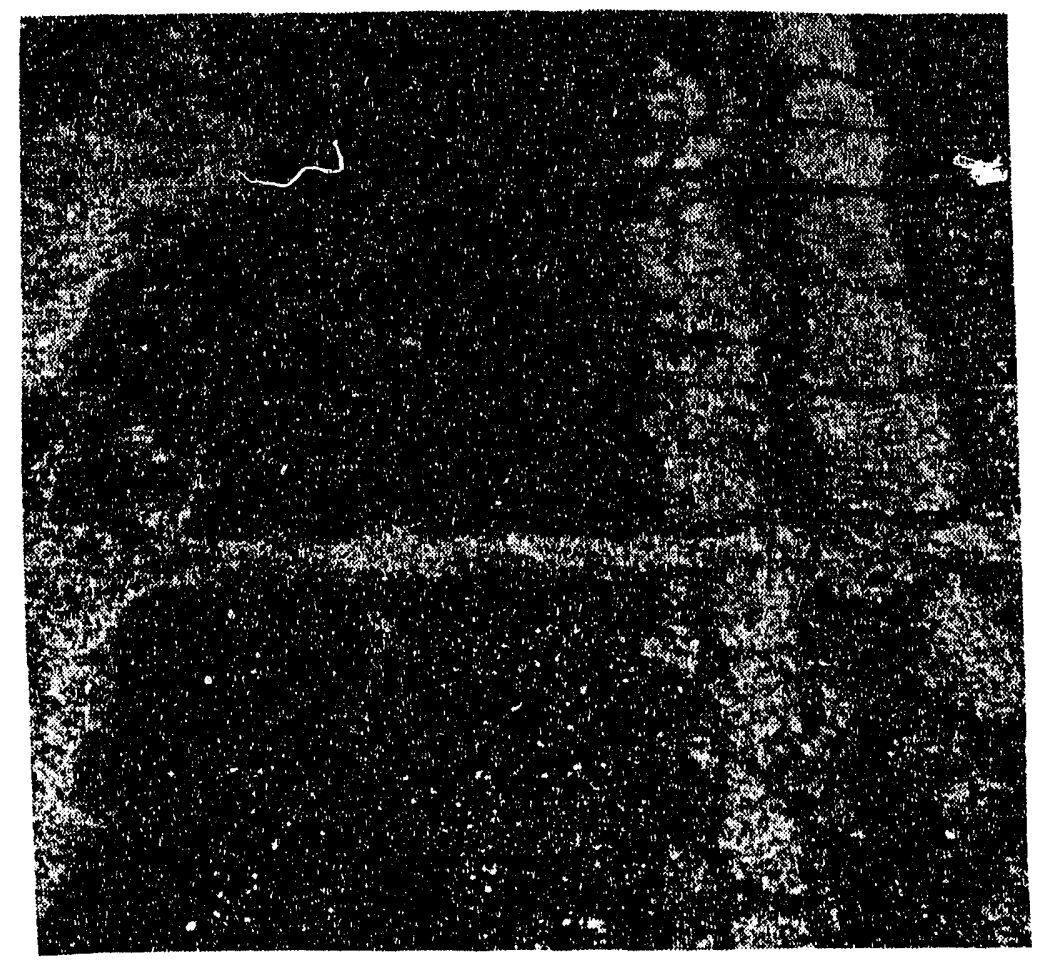

Figure 4. Rough Asphalt Secondary Road 


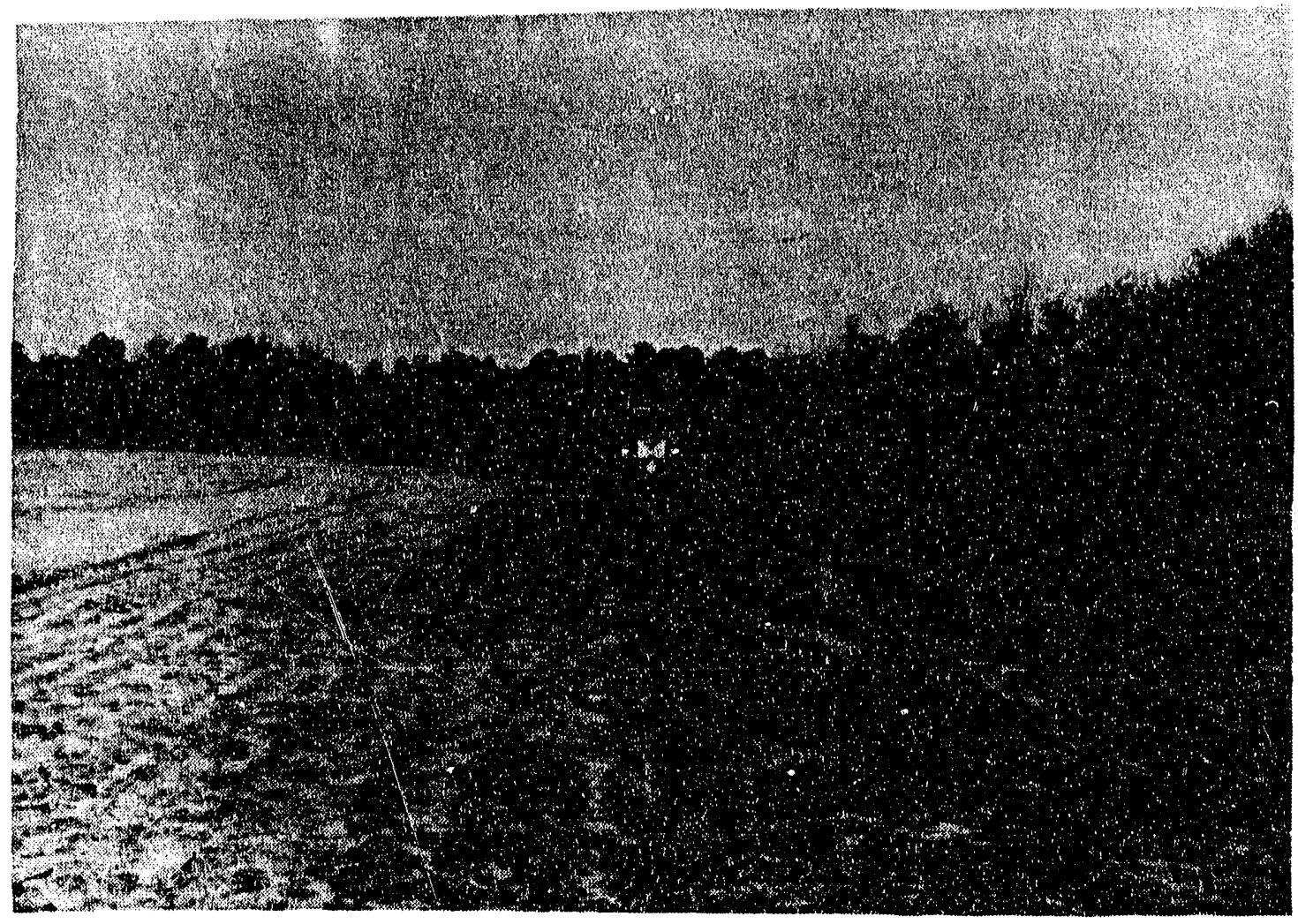

Figure 5. Spalled Asphalt Secondary Road 




Figure 6. Railroad Crossing



Figure 7. Bridge Approach 


\section{Instrumentation}

The primary role of the instrumertation was to obtain the acceleration at various points on the trailer and package, and to either directly measure forces in the flexible tiedown, or to measure strains in the cradle which can be used to determine forces acting on the tiedown. The locations and measurements obtained from each instrument are given in Table 2. A total of nine instruments were used in each test.

A triaxial accelerometer was placed on the package's center top to measure the package response along each axis. The stiffness of the package made this measurement representative of the entire package. At the same longitudinal location, an accelerometer measured the trailer's vertical acceleration. The maximum accelerations on trailer are obtained at its front and rear. Longitudinal and vertical accelerometers were placed on the trailer bed over the rear axle, and a vertical accelerometer placed on the traller over the kingpin. The combination of vertical accelerometers at these three trailer locations allowed the bounce, pitch, and bending modes to be detected. The longitudinal and transverse accelerometers were useful in detecting the effects of braking and turning.

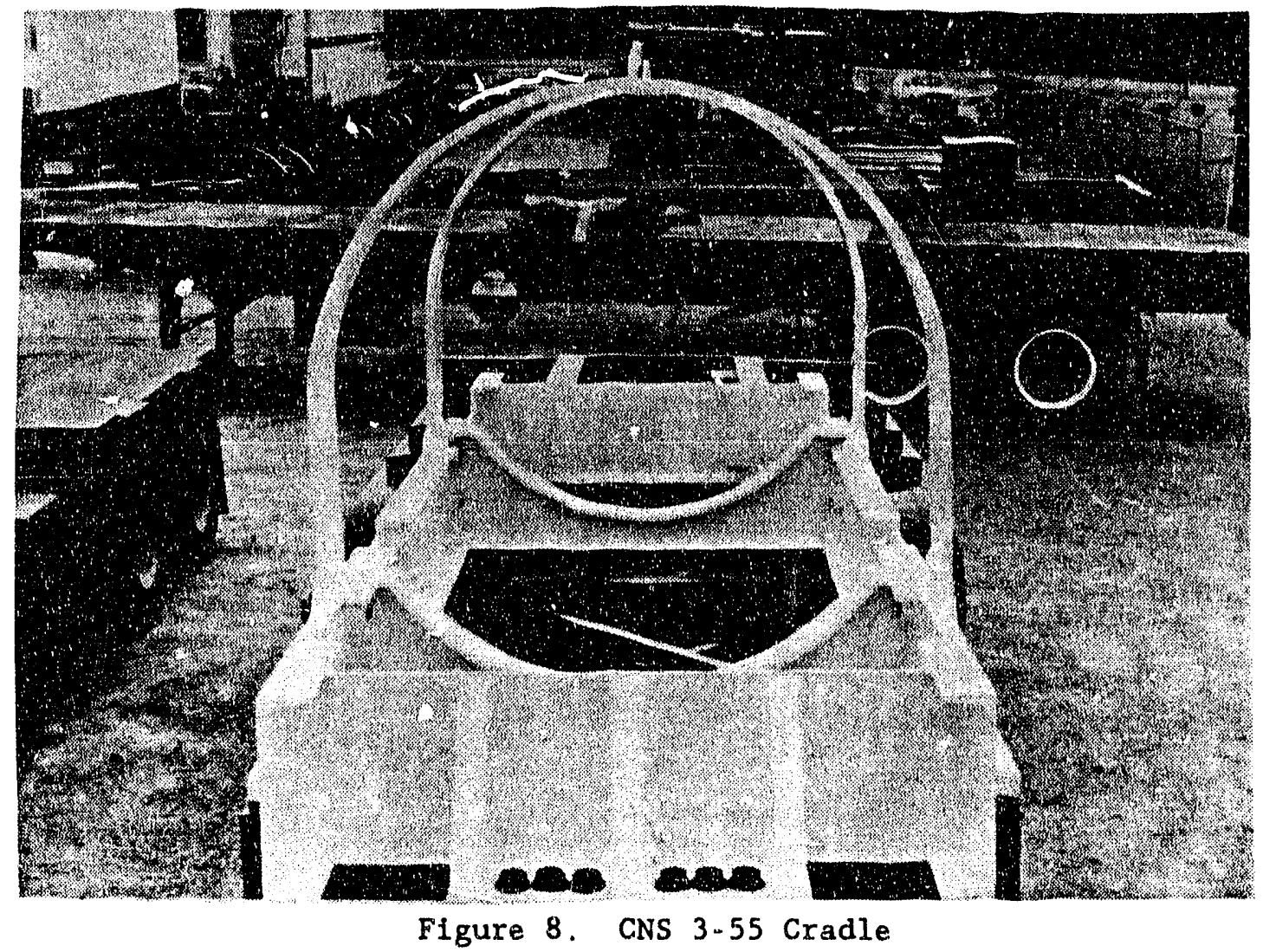




\section{Table 2: Instrumentation Locntions}

$\begin{array}{cc}\text { Lecation } & \text { Test } \\ 1 & 1,2 \\ 2 & 1,2 \\ 3 & 1,2 \\ 4 & 1,2 \\ 5 & 1,2 \\ 6 & 1,2 \\ 7 & 1,2 \\ 13 & 1 \\ 14 & 1 \\ 13 & 2 \\ 14 & 2\end{array}$

\section{Lecrition}

Package Top

Package Top

Package Top

Traller Center

Trafler Rear

Trailex Rear

Trailer Front

Front Tledown

Rear Tledown

Front Tiedown Strap

Rear Tledown Strap
Measurement

Transverse Acceleration

Vertical Acceleration

Longitudinal Acceleration

Vertical Acceleration

Vertical Acceleration

Longitudinal Acceleration

Vertical Acceleration

Separation Force

Separation Force

Vertical Strain

Vertical strain

The response of the tledown systems was determined from load cells in the links between attachant points on the CNS 14-170 and with strain gages mounted on the cradle straps for the CNS 3-55. The load cel. was zeroed after preloading so that only transport-induced loads are measured. The strain gages were arranged in a bridge to remove the effects of bending and hence only measure the strain in the direction of the strap.

The uncertainty that can be expected in the data $15 \pm 15$ percent (4) based on uncertainty analyses of data acquisition systems, data reduction techniques, and transducers at Sandia. This uncertainty exceeds manufacturer's published uncertainty values for each type of transducer, since it includes the spectrum of activitizs required to obcain, analyze, and present data.

\section{Test Resul.t:}

This section descrlbes the results for the over-the-roal tests. Because of the volune of information acquired from tests of this type, the actual time histories and resultant power spectral densities (FSD) are located in the appendices. The resules for Test 1 are located in Appendix $A$, and the results for Test 2 are located in Appendix $B$. The plot of measured time history and the derived PSD for each transducer are grouped by event in the appendices. Appendix A also contains a description of the date reduction technique.

Shock events, such as the rallroad grade crossing and bridge apprusch, axe not stationary events, and hence PSD calculations are not appropriate. Rigld body events, such as the turn and hard stop, were performed to determine the response magnitude only, independent of frequency response.

It is frow these data that the results are sumarized. The time histories provide the mean-to-peak response at the different locations. From these time histories, the auto spectral density (PSD) is generated. The PSD transforms the time history data into the frequency domain to 
relate how the response energy varles as a function of frequency. From this data, it is determined which modes of vibration are contributing to the overall response, and the root-mean square response (RMS) can also be calculated.

Table 3 sumwarizes the peak acceleration results for Test 1 . The RMS responses are presented in Table 4. The tiedown responses are given in Table 5. The results of Test 2 are presented in Tables 6,7 , and 8 .

Table 3: I ik Accelerations for Shock and Vibration Event\& (8), CNS 14-170?

Accelerometer ${ }^{1}$

$\begin{array}{llllllll} & 1 & 2 & 3 & 4 & 5 & 8 & 9 \\ 1 & 0.17 & 0.16 & 0.21 & 0.28 & 0.12 & 0.13 & 0.22 \\ 2 & 0.23 & 0.62 & 0.32 & 0.45 & 0.20 & 0.35 & 0.58 \\ 3 & 0.17 & 0.9 & 0.38 & 0.63 & 0.22 & 0.64 & 0.88 \\ 4 & 0.21 & 2.3 & 0.37 & 0.85 & 0.07 & 0.07 & 0.08 \\ 5 & 0.46 & 5.3 & 1.4 & 4.6 & 0.95 & 1.68 & 3.1 \\ 6 & 0.14 & 2.8 & 0.37 & 1.65 & 0.22 & 0.43 & 0.85 \\ 7 & 0.73 & 4.5 & 1.7 & 3.4 & 1.3 & 2.7 & 4.5\end{array}$

1. Accelerometer locations and direction are: 1 - Package Top, Transverse; 2 - Package Top, Vertical; 3. - Package Top, Longltudinal; 4 - Traller Middle, Vertical; 5 - Trailer Rear, Vertical; 6 - Trailer Rear, Longitudinal; 7 - Trailer Front, Vertic:al.

2. Events are: 1 - Smooth Asphalt; 2 - Rallroal Crossing; 3 - Rough Asphalt; 4 - Bridge Approach; 5 - Rough Concrete; 8 - Secondary Asphalt; 9 - Spalled Asphalt.

The time history shown in. Figure $9 \mathrm{a}$ is the measured vertical acceleration of the rear trailer bed in response to the spalled asphalt event for Test 1 . This figure shows a fairly severe vibrational environment, with two large transient events occurring 3 and 9 seconds into the run. There is also a quieter section from 6 to 7 seconds. The random nature of the data is evident from the time histories.

Figure $9 \mathrm{~b}$ shows the same response in the frequency domain, in PSD form. The resporse is shown as $\mathrm{g}^{2} / \mathrm{Hz}$ on $\log -\log$ plot. The larger response at $1.5 \mathrm{~Hz}$ is due to the E1rst bounce mode of the tractor/trailer 
combination. This bounce mode of the vehicle is caused by the structure bouncing in unison on the suspension system of the trai?er. The next feature seen in Figure $9 \mathrm{~b}$ is the response $4 \mathrm{~Hz}$. This ts the frequency of the vehicle's first pitciing mode. This is caused by the kingpin/re ir tractor suspension deflecting down while the trailer rear suspension and tractor front suspension deflect up. The high-frequency modes, from 10 to $20 \mathrm{~Hz}$, are combinations of the traller bending with the tractor pitching and bending. The first benoing mode pccurs at approximately $11 \mathrm{~Hz}$.

Table 4: RNS Accelerations (g) for Vibration Events, CNS 14-170

Accelerometer ${ }^{1}$

\begin{tabular}{|c|c|c|c|c|c|}
\hline & 1 & 3 & $\begin{array}{l}5 \\
\end{array}$ & 8 & 9 \\
\hline & 0.042 & 0.043 & 0.025 & 0.027 & 0.054 \\
\hline & 0.041 & 0.096 & 0.050 & 0.066 & 0.125 \\
\hline & 0.041 & 0.057 & 0.055 & 0.143 & 0.227 \\
\hline & 0.040 & 0.093 & 0.01 & 0.011 & 0.011 \\
\hline & 0.135 & 0.211 & 0.233 & 0.401 & 0,718 \\
\hline & 0.030 & 0.042 & 0.059 & 0.088 & 0.180 \\
\hline & $0 . ?-\ldots$ & 0.294 & 0.403 & $c=11$ & 1.03 \\
\hline
\end{tabular}

1. Accelerometer locations and direction are: 1 - Package Top, Transverse; 2 - Package Top, Vertical; 3 - Package Top, Longitudinal; 4 - Trailer Middle, Vertical; 5. Traller Rear, Vertical; 6 - Trafler Reax, Longitudinal; 7 - Trailer Front, Vertical.

2. Events are: 1 - Smooth Asphalt, 3 - Rough Asphalt, 5 - Rough Concrete, 8 - Secondary Asphalt, 9 - Spalled Asphalt.

Table 5: Peak Tledow, Loads (1bs), CNS 14-170

Load Cell1 Event ${ }^{2}$

$\begin{array}{llllllllll} & 1 & 2 & 3 & 4 & 5 & 6 & 7 & 8 & 9 \\ 13 & 430 & 700 & 580 & 400 & 220 & 800 & 630 & 350 & 460 \\ 14 & 220 & 650 & 360 & 300 & 150 & 550 & 480 & 280 & 650\end{array}$

1. Load cell locations are: 13 - Front Tiedown, 14 - Rear Tiedown.

2. Events are: 1 - Smooth Asphalt, 2 - Rallroad Crossing, 3 - Rough Asphalt, 4 - Bridge Approach, 5-Rough Concrete, 6 - Turn, 7 - Stop, 8 - Secordary Asphalt, 9 - Spalled Asphalt. 
Table 6: Peak Accelerations (8) for Shock and Vibration Events, CNS 3-55

Accelerometer ${ }^{1}$

$\begin{array}{llllllll} & 1 & 2 & 3 & 4 & 5 & 8 & 9 \\ 1 & 0.1 & 0.14 & 0.13 & 0.11 & \ldots & 0.34 & \ldots \\ 2 & 0.12 & 0.47 & 0.25 & 0.23 & 0.12 & 0.37 & 0.2 \\ 3 & 0.12 & 0.50 & 0.15 & 0.45 & \ldots & 0.38 & 0.28 \\ 4 & 0.09 & 0.8 & 0.25 & 0.32 & 0.17 & 0.35 & 0.22 \\ 5 & 0.55 & 5.9 & 1.4 & 2.4 & 1.0 & 2.7 & 1.95 \\ 6 & 0.33 & 3.0 & 0.21 & 0.47 & 0.3 & 0.81 & 0.4 \\ 7 & 0.85 & 6.5 & 1.1 & 3.4 & 1.2 & 3.4 & 2.65\end{array}$

1. Accelerometer locations and direction are: 1 - Package Top, Transverse; 2 - Package Top, Vertical; 3 - Package Top, Longitudinal; 4 - Trafler Middle, Vertical; 5 - Traller Rear, Vertical, 6 - Trailer Rear, Longitudinal; 7 - Trailer Front, Vertical.

2. Events are: 1 - Smooth Asphalt, 2 - Rallroad Crossing, 3 - Rough Asphalt, 4 - Bridge Approach, 5 - Rough Concrete, 8 - Secondary Asphalt, 9 - Spalled Asphalt.

The calculation of RMS response alsc uses the PSD format. The mean squared response is the area under the PSD response curve. The RMS is the square root of this value. The RMS relates the probability of a certain level of resporise occurring, and is equal to the standard deviation since the metan is zero. For example, three times the RMS will envelope 99.9 percent of all expected responses.

The transform magnitude plots for the railroad grade crossing event are also shown in the appendices. These plots axe discrete Fourier transforms of the measured response and are provided to show the frequency content of the translent record. Shock spectra are not presented because the structure can not be assumed to resemble a single degree-of-freedom system. For the other shock-producing events, only the time history is presented.

The complete time histories and PSD responses are located in the appendices. The description of the individual events for Test 1 follows and reference should be made to the figures located in Appendix A, Figures Al through Al24. Refer to Table 2 for instrumentation locations. 
Table 7: RHS Accelerations (g) for Vibration Events, CNS 3-55

Accelerometer 1

Event ${ }^{2}$

$\begin{array}{cccccc} & 1 & 3 & -5 & -8 & 9 \\ 1 & 0.02 & 0.032 & \ldots & 0.042 & \ldots \\ 2 & 0.027 & 0.072 & 0.024 & 0.075 & 0.043 \\ 3 & 0.023 & 0.035 & \ldots & 0.097 & 0.075 \\ 4 & 0.027 & 0.069 & 0.028 & 0.078 & 0.048 \\ 5 & 0.28 & 0.23 & 0.24 & 0.65 & 0.53 \\ 6 & 0.028 & 0.042 & 0.058 & 0.11 & 0.096 \\ 7 & 0.102 & 0.22 & 0.32 & 0.77 & 0.63\end{array}$

1. Accelerometer locations and direction are: 1 - Package Top, Transverse; 2 - Package Top, Vertical; 3 - Package Top, Longitudinal; 4 - Trailer Middle, Vertical; 5 - Traller Rear, Vertical, 6 - Trailer Rear, Longitudinal; 7 - Traller Front, Vertical.

2. Events are: 1 - Smooth Asphalt, 3 - Rough Asphalt, 5 - Rough Concrete, 8 - Secondary Asphalt, 9 - Spalled Asphalt.

Table 8: Peak Tiedown Loads (Ibs), CNS 3-55

Strain Gage ${ }^{1}$

Event $^{2}$

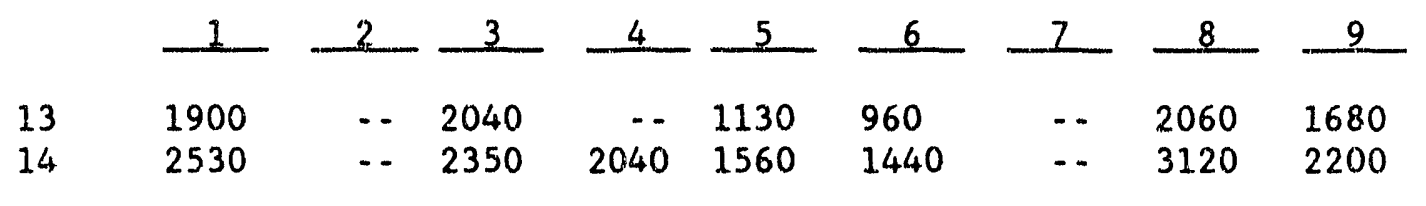

1. Strain Gage locations are: 13 - Cradle Front, 14 - Cradle Rear.

2. Events are: 1 - Smooth Asphalt, 2 - Railroad Crossing, 3 - Rough Asphalt, 4 - Bridge Approach, 5 - Rough Concrete, 6 - Turn, 7-Stop, 8 - Secondary Asphalt, 9 - Spalled Asphalt. 


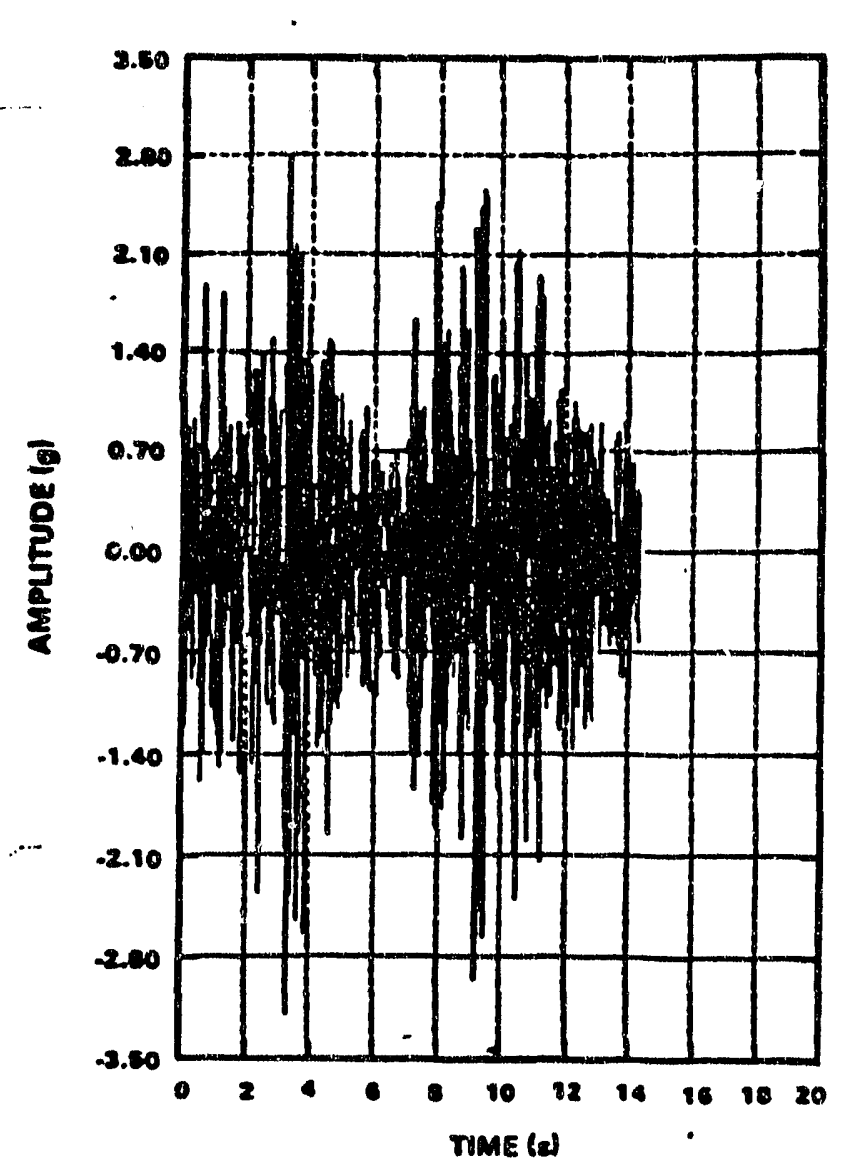

Figure 9a. Representative Time History

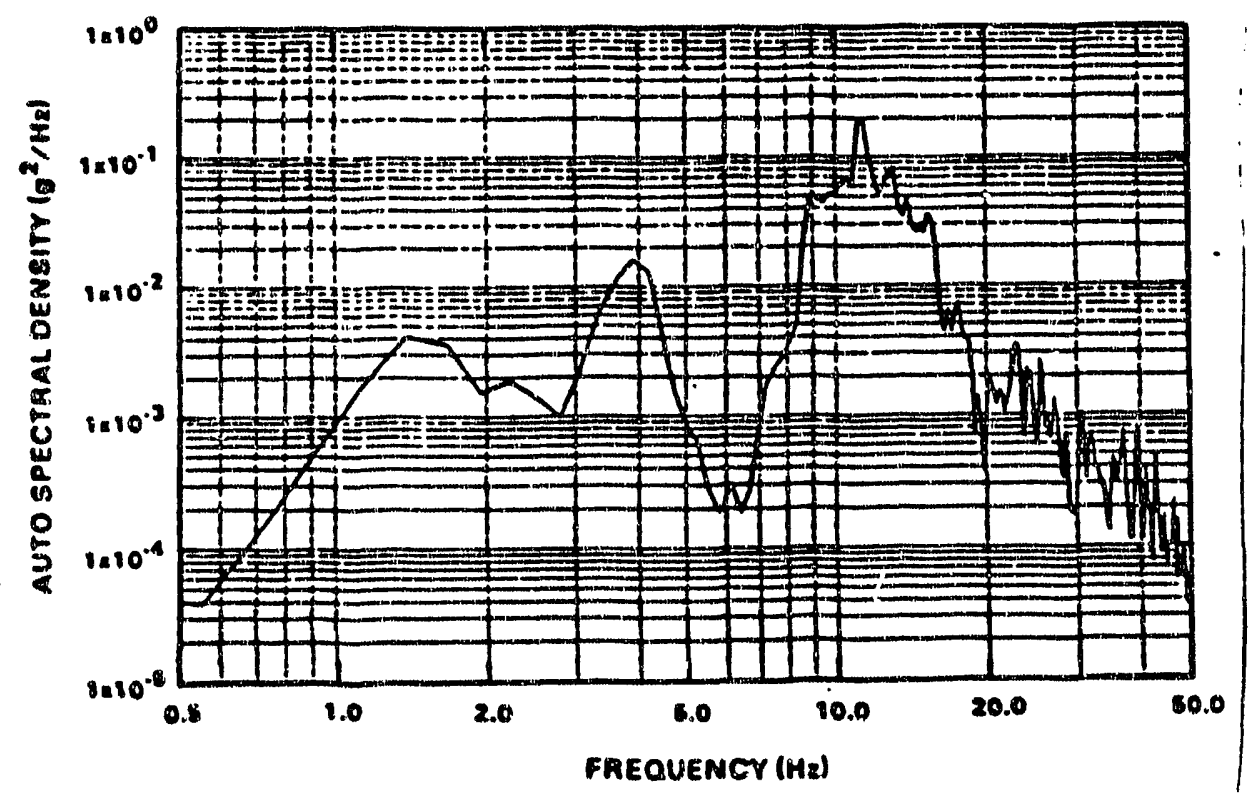

Figure 9b. Representative PSD 


\section{Test 1 Results}

Event 1 was the smooth asphalt road. The responses are shown in Figures Al through A18. The road was driven at $55 \mathrm{mph}$ and included a bridge crossing. The package acceleration and tiedown load responses were very small with an average RMS acceleration of $0.042 \mathrm{~g}$ in all three directions, and a peak acceleration of $0.23 \mathrm{~g}$. Locations on the trailer bed experienced a greater response level, with the trailer kingpin being the greatest at $0.2 \mathrm{~g}$ RMS, and a peak response of $0.73 \mathrm{~g}$. The bridge crossing can be seen in the time histories, and is responsible for the peak response in most records. The force in the tiedowns was measured to be 220 lbs. peak and $70 \mathrm{lbs}$. RMS for the rear and $430 \mathrm{lbs}$. peak and $141 \mathrm{lbs}$. RMS for the front tiedown. This corresponds to a maximum load in the tiedowns of $0.009 \mathrm{~g}$ with respect to the packaging weight.

Event 2 was the railroad grade crossing. The time histories for this event are shown in Figures A19 through A27. The rail crossing was traveled at a speed of $30 \mathrm{mph}$ and produced a severe shock to the vehicle. Table III shows the largest peak responses measured for this structure. The package top shows peak accelerations of $0.16 \mathrm{~g}$ transverse. $0.62 \mathrm{~g}$ vertical and 0.9 8 longitudinal. The rear of the trailer shows a $5.2 \mathrm{~g}$ peak acceleration vertically, and $2.8 \mathrm{~g}$ acceleration longitudinally, while the front of the trailer experienced a $4.5 \mathrm{~g}$ peak vertical acceleration. The peak force in the tiedown was $700 \mathrm{lbs}$. for the front, and $650 \mathrm{lbs}$. for the rear. This corresponds to a maximum tiedown load of $0.015 \mathrm{~g}$.

From the frequency analysis of the railroad crossing shock data, shown in Figures A28 through A36, It is possible to see the modes which contribute to the shock response. The package vertical response is due primarily to the bounce mode of the structure at $1.5 \mathrm{~Hz}$, shown in Figure A29, while the longitudinal response is due to the first pitch mode at: $4 \mathrm{~Hz}$, and to the bending modes above $10 \mathrm{~Hz}$. The accelerometer at the trailer center was apparently close to a vibration node as it shows response due primarily to the bounce mode, and very little response due to the pitch or bending modes of the trailer. This is a graphic demonstration of the spatial dependence of response on the trailer bed. The vertical response at the rear and the front of the trailer, shown in Figures $A 32$ and A34, shows strong contributions from the first several modes. This is predictable at these locations because they are the only points having large deflections due to the bounce, pitch, and bending of the trailer. From Figures A35 and A36, it can be seen that the force response in the tiedown is primarily due to the bounce mode, with some additional influence from the first bending mode of the trailer.

Event 3 was the rough asphalt primary road surface. Figures A37 through A54 show the results for this test. This test track was driven at a speed of $45 \mathrm{miph}$. The package peak accelexation was $0.38 \mathrm{~g}$ longitudinally, $0.057 \mathrm{~g}$ RMS, $0.32 \mathrm{~g}$ vertically, and $0.096 \mathrm{~g}$ RMS. Package vertical accelerations were primarily due to the first bounce mode, while the longitudinal acceleration was composed of bending modes, with a les er input from the first pitch mode. Trailer vertical accelerations of $1.4 \mathrm{~g}$ peak at the rear and $1.7 \mathrm{~g}$ at the front were measured. The RMS levels at these locations were $0.211 \mathrm{~g}$ and $0.294 \mathrm{~g}$, respectively. Maximum forces 
measured in the tiedowns were $580 \mathrm{lbs}$. In the front, $156 \mathrm{lbs}$. RMS, and 360 lbs. In the rear, 93 lbs. RMS. This corresponds to a maximum tiedown load of $0.012 \mathrm{~g}$.

Review of the time history shows a large transient between two and four seconds in the test in Figure A41. The high package longitudinal response is due to the trailex's pitching response. A single low dip across the road surface was the cause of this shock, and since no unusual transverse response was detected, the dip was symmetrical to the direct.. on of trave1. This is demonstrated by the time delay in the vertical response of the traller front and rear. Because of this transient superimposed on the vibration data, the RMS response is much less than the peak for all vertical responses. The package longltudinal peak acceleration is higher than the vertical response, even though the longitudinal RMS level is much less than the vertical.

Event 4 was the bridge crossing. Figures A55 through A63 show the time histories for this event. The bridge was crossed at a speed of 54 $\mathrm{mph}$. The most notable responses were measured in the longitudinal direction, where the package peak acceleration was $0.63 \mathrm{~g}$, which was greater than the package vertical acceleration of $0.45 \mathrm{~g}$. The rear trailer location had the greatest measured response of $4.6 \mathrm{~g}$, while the trailer front measured $3.4 \mathrm{~g}$. For every location the measured response was less than the railroad grade crossing event. The tledown forces were approximately half the rail crossing, with $400 \mathrm{lbs}$. peak in the front tiedown, 300 lbs. peak in the rear. This corresponds to a maximum tiedown load of $0.008 \mathrm{~g}$.

Event 5 was the rough concrete pavement. The concrete was overlain with an old layer of: asphalt in which the surface was broken up along the joints of the concrete sections. Peak response levels were approximately two thirds of those measured for the rough asphalt event, and the tiedown forces were approximately half. The RMS responses were comparable with the rough asphalt, though for the trailer rear the rough concrete levels were higher. The mid-trailer response was caused mainly by the pitching of the structure, while the response to the rough asphalt was primarily due to the first bounce mode. This correlates to the generally higher frequency input of the rough concrete. For similar reasons, the response of the kingpin was made up primarily of high frequency bending modes, while the rough asphalt kingpin response was composed of the bounce mode and bending response.

The tiedown PSD functions also showed a greater percentage of energy due to the bending modes above $10 \mathrm{~Hz}$. The tiedown forces were measured to be $220 \mathrm{lbs}$. peak and $55 \mathrm{lbs}$. RMS for the front tiedown, and $150 \mathrm{lbs}$. peak and $36 \mathrm{lbs}$. RMS for the rear tiedown, for a maximun tiedown load of $0.004 \mathrm{~g}$. The tledown RMS response was one third the level measured in the rough asphalt event.

Event 6 was the hard turn driven at a speed of $26 m_{k} a$. Time histories for the package accelerometer in the transverse direction and the tiedown front and rear force time histories are shown in Figures A82 through A84, respectively. This event was completed to show the actual tiedown forces 
which result from a severe turn. A side acceleration of $0.42 \mathrm{~g}$ was measured at the package top, and peak tledown restraint forces of $800 \mathrm{lbs}$. forward and $500 \mathrm{lbs}$. rear were seen in the event. This maximum tiedown force of $0.017 \mathrm{~g}$ was the largest measured during Test 1 .

Event 7, a hard stop, was used to corplete the maneuvering data. The truck had an initial speed of $54 \mathrm{mph}$. Th1s stopping event was equivalent to an emergency stop as all wheels were locked and the truck stopped in 3.4 seconds. The package top longitudinal accelerometer and rear longitudinal accelerometer time histories, shown in Figure $A 85$ and $A 86$, respectively, measured a $0.6 \mathrm{~g}$ deceleration for the stop. Package tiedown force time histories show a peak force of $630 \mathrm{lbs}$. or $0.013 \mathrm{~g}$ in the front tiedown, and 480 lbs. In the rear, as shown in Figures $A 87$ and $A 88$, respectively.

Event 8 was the secondary asphalt event, driven at a speed of $20 \mathrm{mph}$. The time historles and PSD for this event are shown in Figures A89 through A106. As expected, the response levels are all above those measured for the rough asphalt test. The PSD functions show much greater response due to the bending of the trailer than during the rough asphalt event. The middle accelerometer response was twice the rough asphalt. The PSD shows that pitching of the trailer was responsible for this increase. Both trailer rear and front responses showed a significant increase in the bending mode participation.

The tiedown response also showed a significant participation by the higher frequency bending modes. Again, the trailer response does not translate directly into tiedown forces. The measured tiedown forces for this event were significantly less than for the rough asphalt event, even though the trailex response was significantly higher than for the rough asphalt. The tiedown forces were approximately 60 percent of the rough asphalt restraint forces even though the traller responses were up to 60 percent higher. Peak tiedown forces were $350 \mathrm{lbs}$. or $0.007 \mathrm{~g}$ for the front, and $280 \mathrm{lbs}$. for the rear location. The RMS levels for the trailer were approximately twice the rough asphalt results.

Event 9 was the spalled secondary asphalt road surface driven at a speed of $20 \mathrm{mph}$. Results for this event are shown in Figures A107 through A124. This was a very severe opexation of the truck. This event produced peak accelerations in the package equal to the railroad grade crossing and produced the most severe RMS accelerations. The tiedown RMS levels were found to be $137 \mathrm{lbs}$. for the front and $150 \mathrm{lbs}$. for the rear, and the peak forces were measured to be $460 \mathrm{lbs}$. for the front and $650 \mathrm{lbs} .$, or $0.014 \mathrm{~g}$, for the rear. These peak forces were of the same magnitude as the railroad grade crossing, and the RMS levels were similar to the rough isphalt for the front tiedown. The rear tiedown RMS level is the highest measured at this location for all events, and the PSD function shows response due to the bounce and bending modes. All PSD functions show strong response due to the bending of the trailer.

\section{Test 2 Results}

The results for the heavier, Type B package will be described here. The figures showing the respective test results are located in Appendix $B$. The events were completed in the same order used in Test 1 . For the 
tiedown strain gage data, the conversion factor to produce pounds from strain is $30 \times 10^{6} \mathrm{ps} 1 \times 8$ square inches. As was stated earlier, the configuration of the strain gages provided net axial force in the tiedown straps.

Event 1 was the smooth asphalt surface driven at a speed of $55 \mathrm{mph}$. Figures B1 through B18 show the measured data for this event. Very low response was seen in the package as a maximum of $0.12 \mathrm{~g}$ was measured, 0.027 $g$ RMS. Peak response on the trailer bed was $0.85 \mathrm{~g}$, at the trailer kingpin location. The largest RMS level of $0.102 \mathrm{~g}$ was measured at this same location. Peak force in the tiedowns was 2530 lbs. at the rear station, 1008 lbs. RMS, while $1900 \mathrm{lbs}$. peak was measured in the front tiedown, 840 1bs. RMS. These correspond to a maximum tiedown load of $0.038 \mathrm{~g}$.

Vertical response in the package was primarily due to the bounce mode. For the longitudinal response, the pitch and bending modes were dominant. On the trailer bed the vertical response was equally distributed among the three mode types. The tiedown frequency analysis shows a significant input due to the pitch and bending modes of the trailer, along with the primary bounce mode input. This was caused by the increased length of the package on the trailer which, by geometry, puts the tiedown in a location of greater deformation of the system. The bounce mode was dominant in the results of the front tiedown, whose location is closer to the vibratory node for the bending modes thereby reducing the total input from this mode. The RMS levels in the tiedowns were the highest found for either test.

Event 2, the rallroad grade crossing, provided the maximum responses for both tests. The crossing was traveled at a speed of $38 \mathrm{mph}$. Plots of this event's time history data are shown in Figures B19 through B25. While the package maximum response was $0.5 \mathrm{~g}$ longitudinally and $0.47 \mathrm{~g}$ vertically, the response on the trailer was $6.5 \mathrm{~g}$ vertically at the kingpin, and $5.9 \mathrm{~g}$ vertically at the trailer rear. As expected, the longitudinal response and trailer extreme responses contained pitch and bending mode participation. The middle vertical location was dominated primarily by the bounce mode. The strain gage data was faulty for this event, so no tiedown loads can be reported. The frequency analysis of the shock data, Figures B26 through B32, show a very strong participation of the bending modes to the vertical responses of the trailer.

Event 3 was the rough asphalt primary surface driven at $45 \mathrm{mph}$, and the response data is shown in Figures B33 through B50. Peak response of the package was $0.25 \mathrm{~g}$ vertically, with the other two directions being approximately $0.15 \mathrm{~g}$. The most significant accelerations were found on the trailer extremes in the vertical direction, with $1.4 \mathrm{~g}$ peak at the rear and $1.05 \mathrm{~g}$ peak at the front.

Tiedown forces were among the highest measured for this system. Responses at the rear were a peak of $2350 \mathrm{lbs}$. or $0.035 \mathrm{~g}$ and $878 \mathrm{lbs}$. RMS, and a front peak force of $2040 \mathrm{lbs}$, and $749 \mathrm{lbs}$. RMS. The tiedown PSD show dominance of the bounce mode with a very small participation of the bending mode. Responses of the trailer show a very strong contribution due to the bending modes of the trailer. 
Event 4 was the bridge crossing at $55 \mathrm{mph}$. Time histories for this event are shown in Figures B51 through B59. Levels recorded for this event were less than the rallroad grade crossing. The maximum acceleration on the package was $0.45 \mathrm{~g}$ in the longitudinal direction. Peak trailer bed vertical accelerations were $3.4 \mathrm{~g}$ in the front and $2.4 \mathrm{~g}$ in the rear. The front tiedown showed no appreciable increase due to the event; background nolse caused by the strap inertial effects are all that is seen in the record. The rear tiedown showed a peak $2040 \mathrm{kbs}$. force or $0.031 \mathrm{~g}$.

Event 5 was a rough concrete surface test driven at $47 \mathrm{mph}$. Response plots are found in Figures B60 through B73. The speed was slower than Test 1 because the heavier truck could not go faster up the slight grade. Results for this test were generally less than those of the rough asphalt with some notable exceptions. The RMS levels for the trailer extremes were all higher than the rough asphalt. From the PSD plots we can see a significant input due to the higher frequency modes induced by the concrete surface. The tiedown responses were much lower than they were for the roughi asphalt.

Ijent 6 was the turning event, executed at $28 \mathrm{mph}$. Figure B74 shows the package transverse time history and Figures $B 75$ and $B 76$ show the front and rear tiedown response, respectively. The package showed an overall $0.27 \mathrm{~g}$ response. This is less than for Test 1 because of a heavier load and the wet road surface. The tledown forces measured $960 \mathrm{lbs}$. in the front and $1440 \mathrm{lbs}$. or $0.022 \mathrm{~g}$ in the rear.

Event 7 was the stopping event which started from a speed of $47 \mathrm{mph}$. Figure $B 77$ and $B 78$ show the longitudinal acceleration of the package top and trailer rear. Both accelerometers recorded $0.4 \mathrm{~g}$ deceleration for the event. Again, the wet road conditions resulted in a lower deceleration than Test 1. No appreclable tiedown forces were recorded at either location, and Figures $B 79$ and $B 80$ show the time histories for the tiedowns.

Event 8 was the secondary asphalt event driven at a speed of $40 \mathrm{mph}$. rigures B81 through $B 98$ show the results for this test. This event produced the highest vibration of the package in all three directions. The package averaged $0.36 \mathrm{~g}$ peak acceleration for all three directions, with $0.075 \mathrm{~g}$ RMS vertically and $0.097 \mathrm{~g}$ RMS longitudinally. The trailer response was recorded at $2.7 \mathrm{~g}$ peak for the rear vertical and $3.4 \mathrm{~g}$ peak at the front. The trailer longitudinal response was $0.81 \mathrm{~g}$ peak, the highest measured for vibration event. The RMS levels on the rear of the trailer were the highest measured with $0.65 \mathrm{~g}$ RMS vertically and $0.113 \mathrm{~g}$ RMS longitudinally. A $0.769 \mathrm{~g}$ RMS response was measured at the trailer front.

The tiedown response was also the highest recorded for all the events. The peak force measured was $2060 \mathrm{lbs}$. In the front tiedown and $3120 \mathrm{lbs}$. or $0.047 \mathrm{~g}$ in the rear. The RMS force was found to be $605 \mathrm{lbs}$. In the front. and 881 lbs. In the rear. The high frequency bending modes were responsible for a large part of the response for most of the records, including the tiedown force response.

Event 9 was the spalled asphalt surface driven at $40 \mathrm{mph}$. Figures $B 99$ through B114 show the results for this event. Peak responses in the $0.25 \mathrm{~g}$ range were measured for the package while RMS levels of $0.043 \mathrm{~g}$ vertically 
and $0.075 \mathrm{~g}$ longitudinally were calculated. Trailer vertical response was measured to be $1.95 \mathrm{~g}$ peak at the rear, $0.526 \mathrm{~g} \mathrm{RMS}$, and $2.65 \mathrm{~g}$ peak above the kingpin, $0.628 \mathrm{~g}$ RMS. Forces in the tledowns were measured to be 1680 lbs. peak in the forward location, $523 \mathrm{lbs}$. RMS, and $2200 \mathrm{lbs}$. peak or $0.033 \mathrm{~g}, 765 \mathrm{lbs}$. RMS, in the rear tledown. As with the spalled asphalt surface, the higher frequency modes dominated the rerponse spectrums.

\section{Discussion of Results}

The most severe acceleration from Test 1 was measured at the trailer rear in the vertical direction, $5.3 \mathrm{~g}$, during the railroad grade crossing. The next most severe acceleration of $4.5 \mathrm{~g}$ was measurad e.c the front of the trailer during the railroad grade crossing and during the spalled asphalt event. The greatest acceleration measured for Test 2 was $6.5 \mathrm{~g}$, which was again measured during the rallroad grade crossing, but at the traller front. This was also the greatest acceleration measured for either test. The trailer rear vertical location for the same event was the next most severe at $5.9 \mathrm{~g}$.

Tiedown maximum forces of $800 \mathrm{lbs}$. were measured for Test 1 during the turning event, with the railroad grade crossing being next most severe at 700 lbs. For. Test 2, the maximum tiedown force, 3120 lbs., was measured during the seconciary asphalt event.

For the vibration events of Test 1 , the most severe peak acceleration was measured during the spalled asphalt event, at the trailer front. The secondary asphalt event provided the next most severe results. For Test 2, the secondary asphalt event provided the worst vibxation environment, with the spalled asphalt being next most severe.

For Test 1, the rough asphalt event produced 50-100 percent greater responise than did the smooth asphalt event, both in peak values and in RMS values. Similar results are seen for the RMS values for Test 2 , but the peak response differences are less exaggerated. Tiedown differences for these surfaces are less pronounced for the RMS values for Test 1 and are reversed for Test 2. Upon inspection of the tiedown PSD curves for Test 2 events 1 and 3 , it is evident that the higher frequency responses of the smooth asphalt are greater than those from the rough asphalt test and contribution from these sources push the net response of the tiedown up for event 1. While the amplitude of vibration from the rough input is greater, the package does not respond differentially from the trailex for the bounce mode, whereas the higher frequency bending and pitch modes cause some separation of the package from its cradle.

The length and mass of the package control the type and magnitude of vibration response. Because of the greater length of the package used in Test 2, as compared to the relatively short package used in Test 1 , the spalled asphalt event did not produce accelerations equivalent to the railroad grade crossing event, as was found in Test 1 . Also, because of the height of the package used in Test 1, the package longitudinal accelerations were generally one-half to two times the response from the lower profile package. 
Traller responses for the spalled asphalt event from Test 1 were approximately twice the responses from Test 2 . This was caused by the package stiffening the traller bending responses; the triple axle rear suspension also contributed to the differing responses. The additional mass and stiffer rear suspension used during Test 2 are responsible for the increased accelerations during the railroad grade crossing, as the same displacement time history is imposed on both systems.

The high center of gravity of the package in Test 1 pushes its longitudinal responses equal to or higher than the vertical response. This further illustrates the point that each package system responds in a way based on package configuration, as well as road type. Tiedown forces for a systam cannot be extrapolated from response data from a given location on the trailer bed. A direct example of this is seen in the results of Test 2. The rough asphalt trailer responses were approximately half those from similar locations during the secondary asphalt event, but the tiedown force RMS levels were either equal to or greater than the secondary asphalt events responses, and the peak levels were comparable.

\section{Conclustons}

It is apparent from the test results that the amplitude of the accelerometer responses are dependent on both the type of event to which the system is being subjected and the location of the accelerometer in the package or trailer. The normalized vertical accelerations measured during the CNS 3-55 test at four locations for the shock and vibration events are given in Table 9. The data are normalized to the rafl cros ing acceleration at each location.

The ralliroad crossing produced the largest peak accelerations on the trailer. These result from translating the stepwise displacement function of the road surface into the various response modes of the trailer and package.

Table 10 normalizes the same responses as Table 9, but with respect to the trailer front vertical response for each event. Even for a distributed load such as the CNS 3-55, the front and rear of the trailer experience accelerations at least four times greater than the accelerations at the midplane of the trailer and package. This response is apparent from the tractor/trailer/package mode shapes. For the first pitch and bending modes, the midplane acts as a node while the front and rear of the trailer experience relatively large displacements $(2,3)$.

Finally, the tiedowns in these tests experience the small loads given in Tables 5 and 8 . These forces were less than $0.05 \mathrm{~g}$ based on package weight. This phenomenon is due to the small relative displacements between the package and trailer. These small relative displacements indicate that the package and trailer are acting in unison to the driving force from the suspension system. This force is small when compared with the accelerations measured at other locations on the trailer, as the small percentages in column 2 of Table 10 show. This illustrates the difficulty in extrapolating data from the trailer bed, and attempting to relate this to cask acceleration. 
Table 9: Event Dependence of Normalized Vertical Accelerometer Response Normalized with Respect to the Rail Crossing Response

Smooth Asphalt

Rail Crossing

Rough Asphalt

Bridge Approach

Rough Concrete

Secondary Asphalt

Spalled Asphalt
Trailer

Rear

0.093

1.0

0.24

0.41

0.17

0.46

0.33
Package Top

0.26

0.11

1.0

0.31

0.16

0.53

0.49

0.40

0.52

0.26

0.21

0.18

0.79

0.44

0.52

0.43

0.28

0.41

Table 10: Spatial Dependence of Normal1zed Vertical Accelerometer Response Normalized with Respect to the Traller Bed Front Response

$\begin{array}{llll}\text { Trailer Package } & \text { Trailer Trailer } \\ \text { Rear } & \text { Top } & \text { Middle } & \text { Pront }\end{array}$

Smooth Asphalt

.65

.14

.11

1.0

Rail Crossing

.91

.072

.12

1.0

Rough Asphalt

1.33

.24

.24

1.0

Bridge Approach

.71

.068

.094

1.0

Rough Concrete

.83

.10

.14

1.0

Secondary Asphalt

.79

.11

.10

1.0

Spalled Asphalt

.74

.075

.083

1.0 
1. Glass, R. E. and Gwinn, K. W., "Trupact-I Over the Road Test," SAND870513, Sandia National Laboratories, Albuquerque, NM, 1987.

2. Glass, R. E. and Gwinn, K. W., "Shock and Vibrations Environments: Test and Analysis," Institute of Nuclear Materials Management 27th Arnual Meeting, June 1986.

3. Glass, R. 5. and Gwinn, K. W. "Design Basis for Resistance to Shock and Vibration," 9th Internationel Symposium on the Packaging and Trans. portation of Radioactive Materials, June 1989.

4. Gonzales, A., "Instrumentation Uses to Determine Structural Responses Under Varfous Test Condftions," SAND87-2645, Sandia National

Laboratories, Albuquerque, NM, 1989. 


\section{Appendix A}

\section{DATA REDUCTION TECHNIQUE}

The test data was reduced by the procedure described here. The original test data was recorded as an analog signal from the transducers. A $100 \mathrm{~Hz}$ analog filter was first applied to insure that the recorded data was band limited. This prevents allasing errors during the digitization process. Since the amplitude of signals greater than $50 \mathrm{~Hz}$ are orders of magnitude less than those under $50 \mathrm{~Hz}$, no significant information is lost in the filtering process.

The analog signal was then digitized. The sample rate was determined by the block size times the effective frequency resolution.

Voltage drift inherent in amplifiers and recording circuits causes the voltage to drift in the original signal, and must be removed before the calculations. The mean for each plot is calculated and subtracted out of each record before the PSD and RMS calculations are completed, but the time historles are shown as digitized from the original information. At this point, a fast fourier transform is implemented to transform the data to the frequency domain. Autospectral density plots, PSD, are calculated.

Discrete fourier transforms of the shock data are calculated to produce the transform magnitude plots for these events. A complete description of the data analysis steps are contained in Vibration Data System for SNLA Area III Reference Manual, SAND84-0350. 
Appendix $\mathrm{B}$

DA2A

.

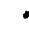

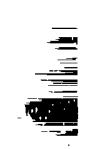




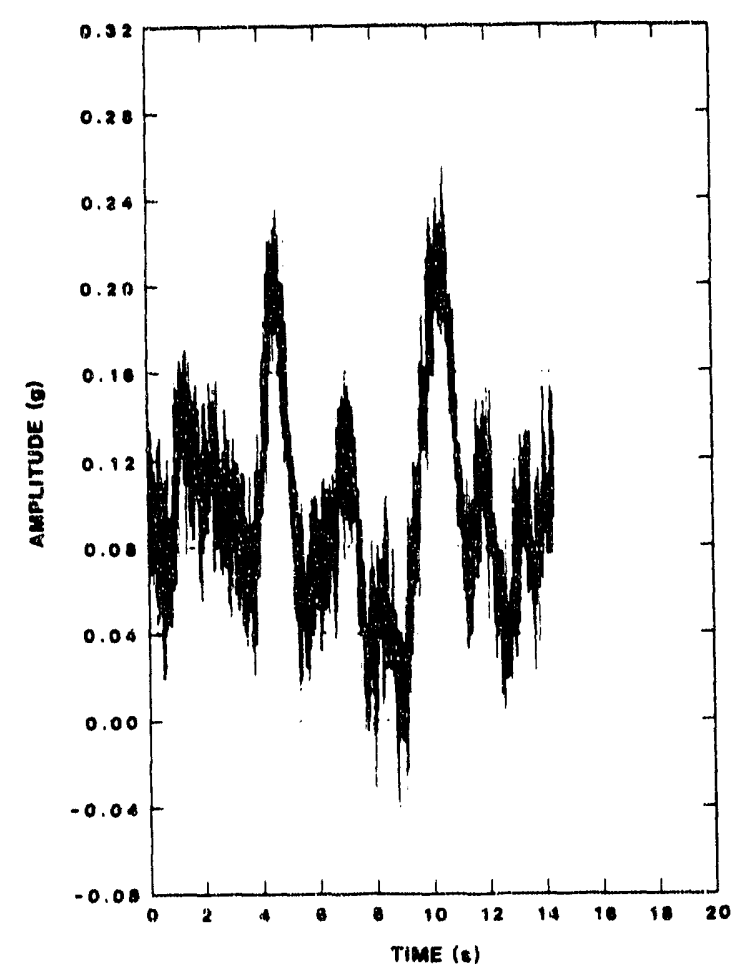

Figure A1. Road Test-CNS 14-170-1 Cask (Test 1) Top Transverse LoC. 1; Smooth Asphalt

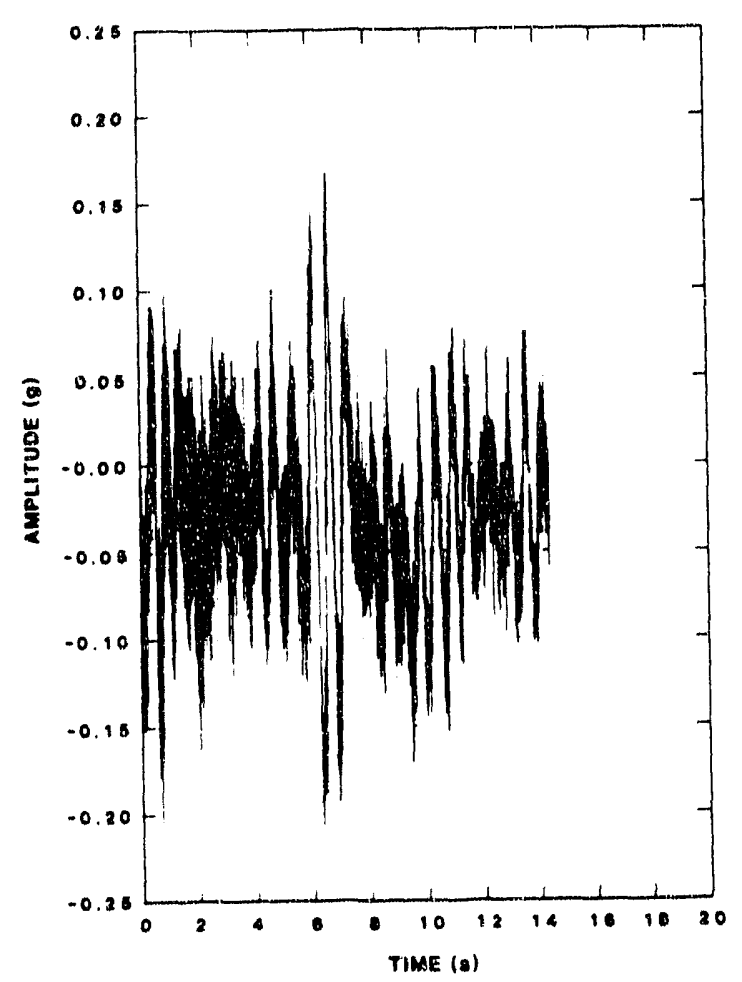

Figuro A3 Road Test-CNS $14-170-1$ Cask (Test 1) Top Vortical LOC 2 , Smooth Asphalt

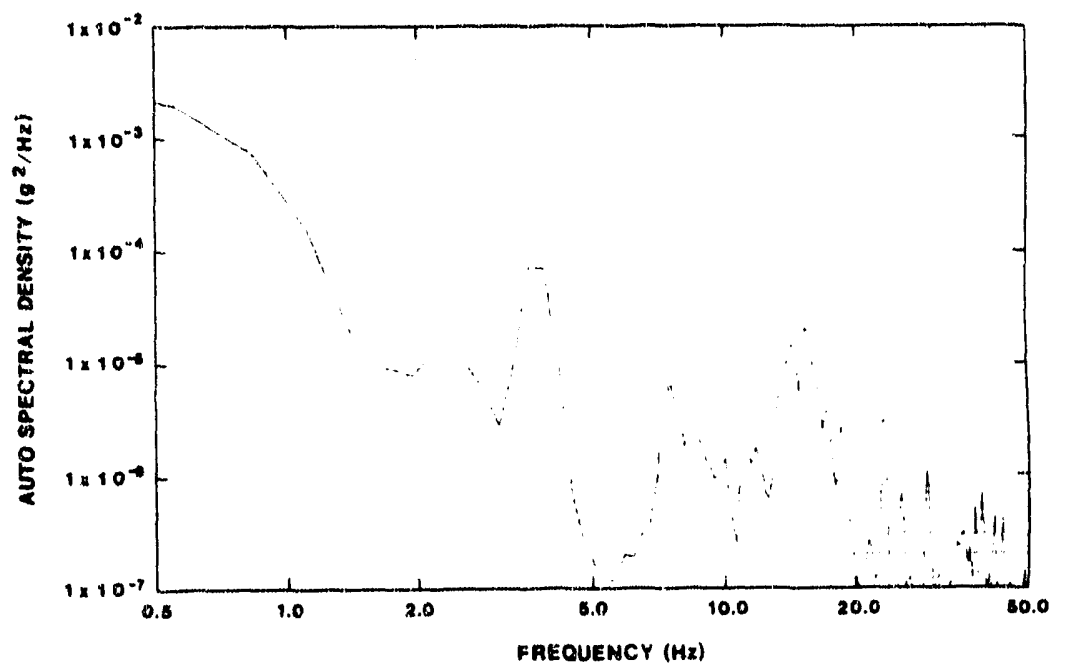

Figure A2. Road Test-CNS 14-170-1 Cask (Test 1) Top Transverse Loc. 1; Smooth Asphalt

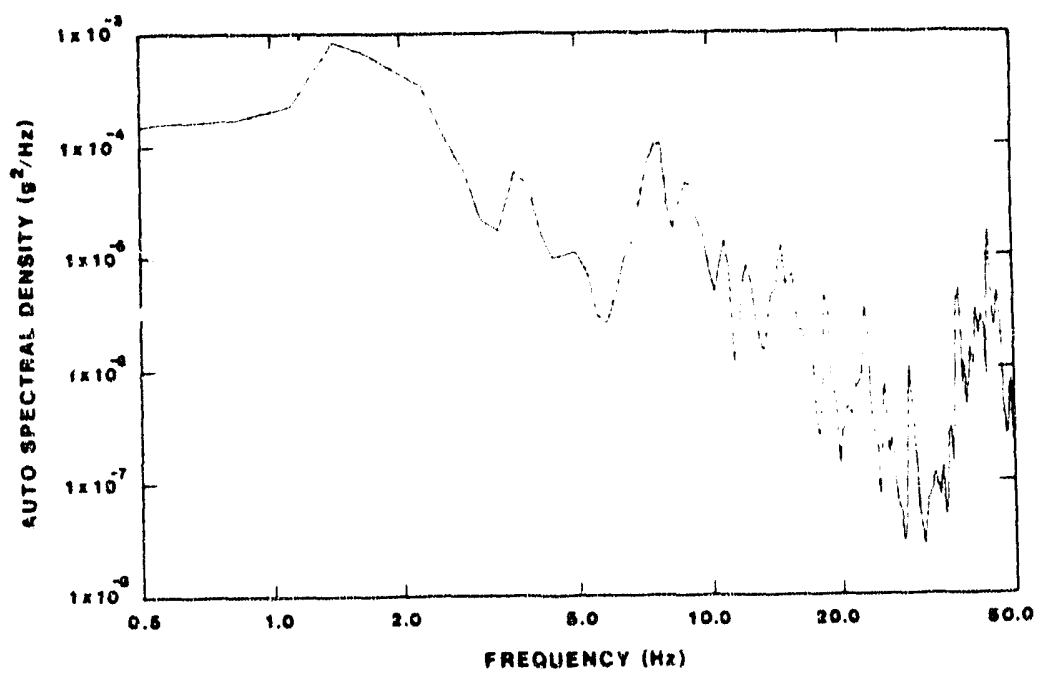

Figure A4. Road Test-CNS 14-170-1 Cask (Test 1) Top Vertica! l.oc. 2; Smooth Asphalt 


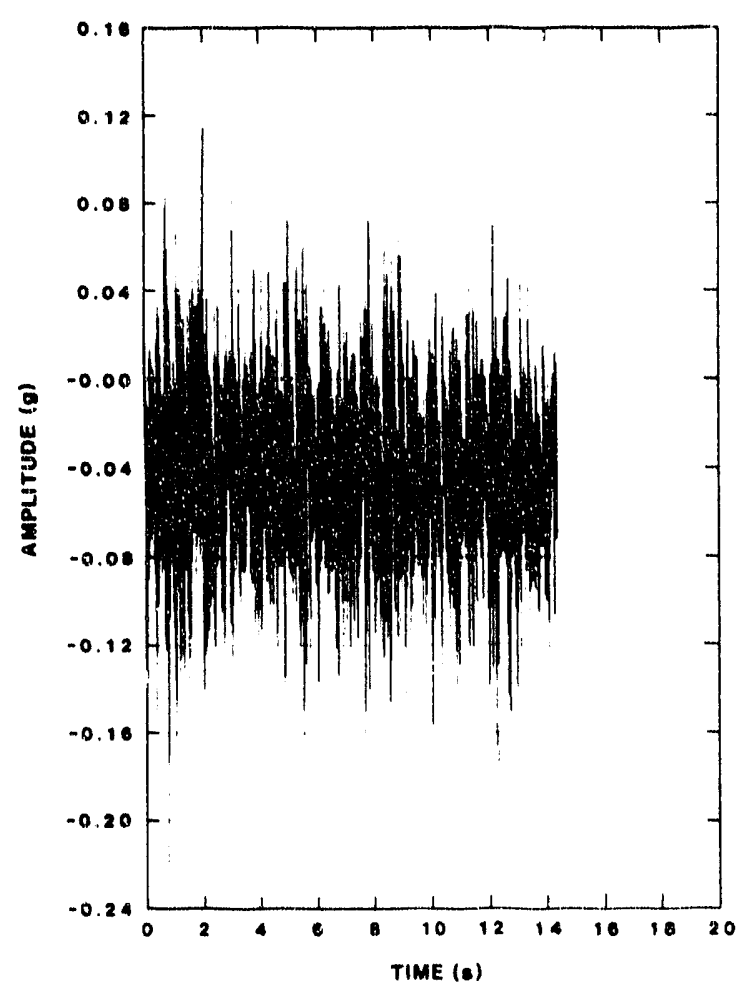

Figure A5. Road Test-CNS 14-170-1 Cask (Test 1)

TOP Longitudinal Loc. 3: Smooth Asphalt

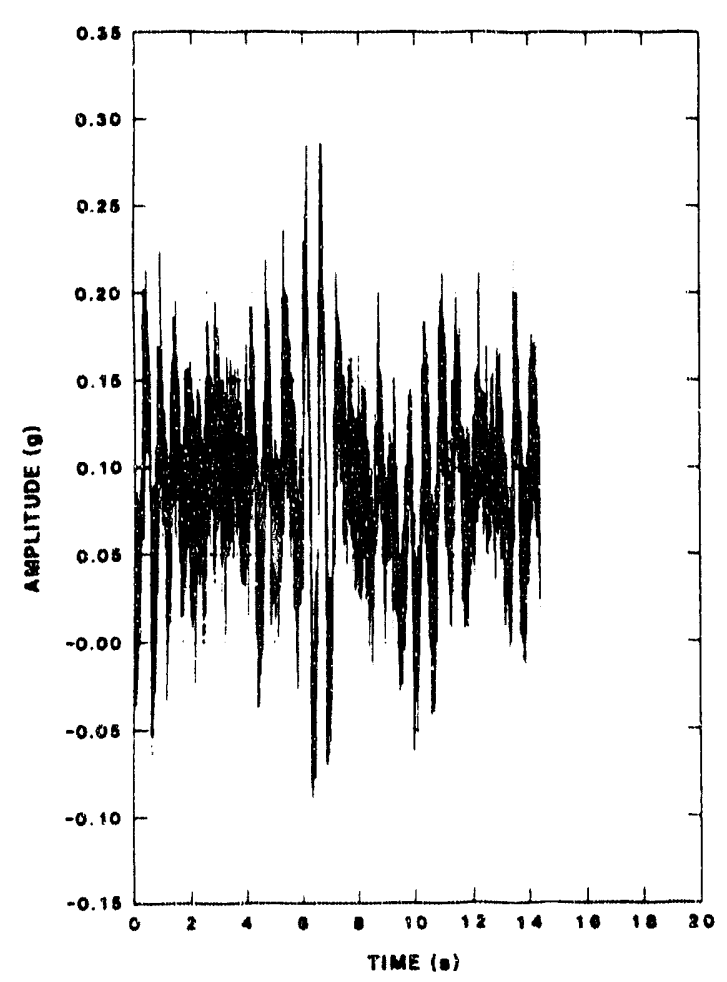

Figure A7. Road Test-CNS 14-170-1 Cask (Test 1) Mid Vertical Loc. 44; Smooth Asphalt

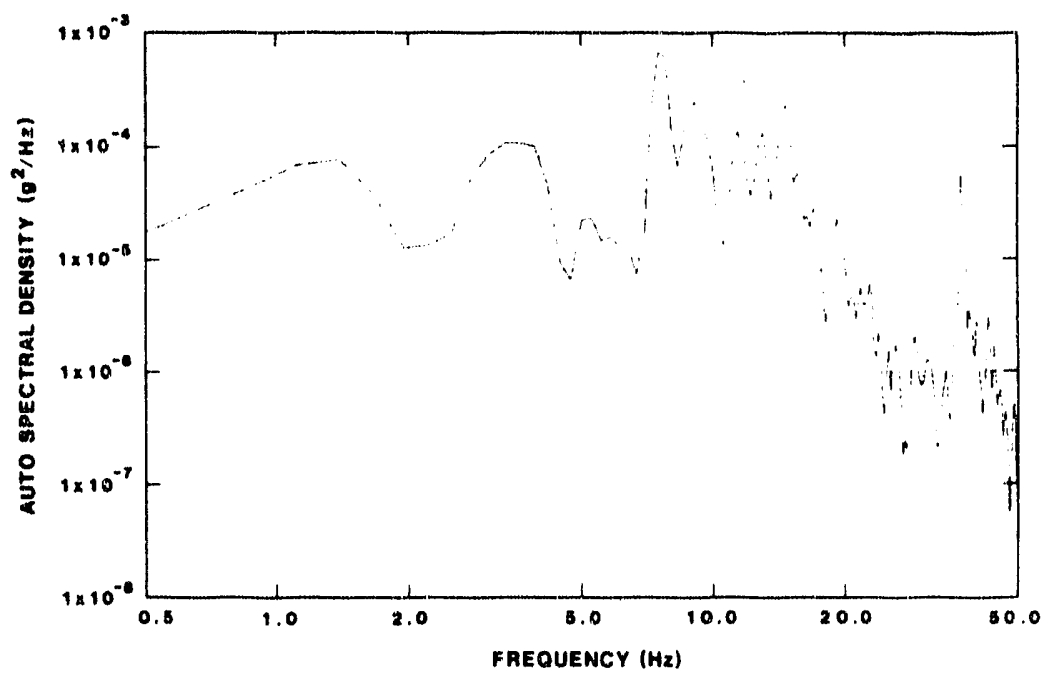

Figure A6. Road Test-CNS 14-170-1 Cask (Test 1)

Top Longitudinal Loc. "3; Smooth Asphalt

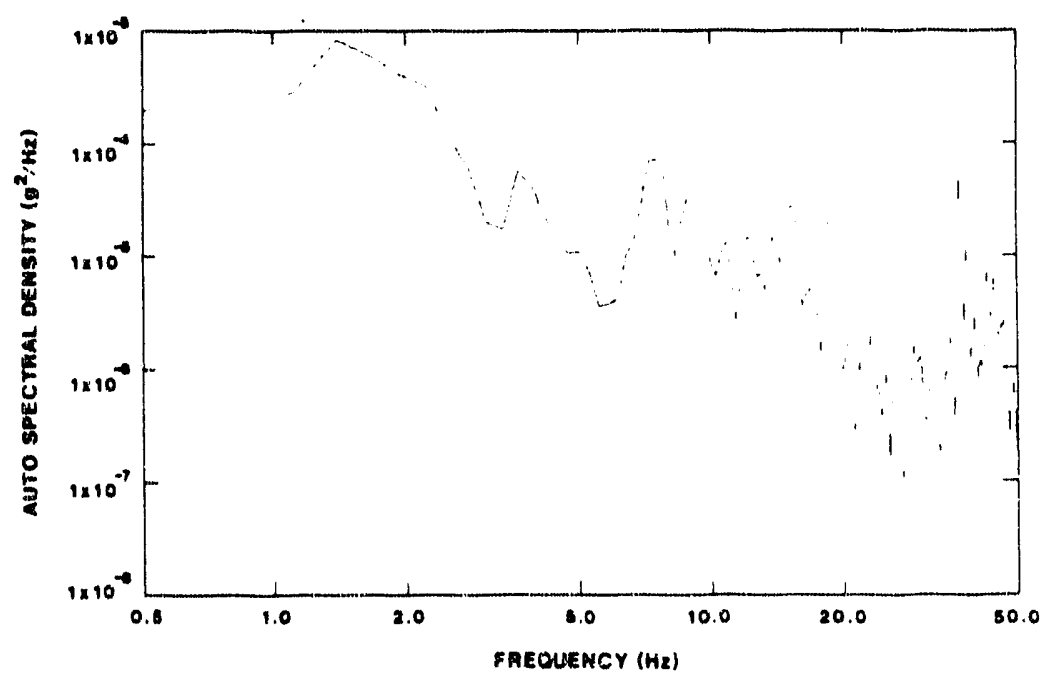

Figure A8. Road Tesi-CNS 14-170-1 Cask (Tost 1) Mid Verical Loc. H4; Smooth Asphalt 


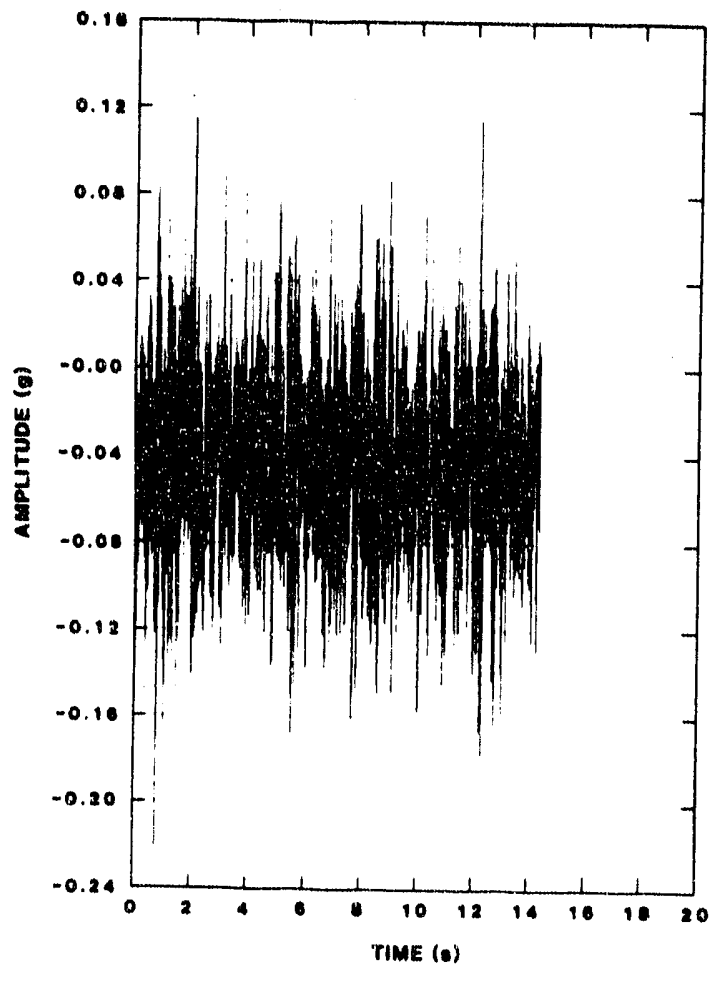

Figure A9. Hoad Test-CNS 14-170-1 Cask (Tost 1) Rear Vertical LoC. $\$ 5$; Smooth Asphalt

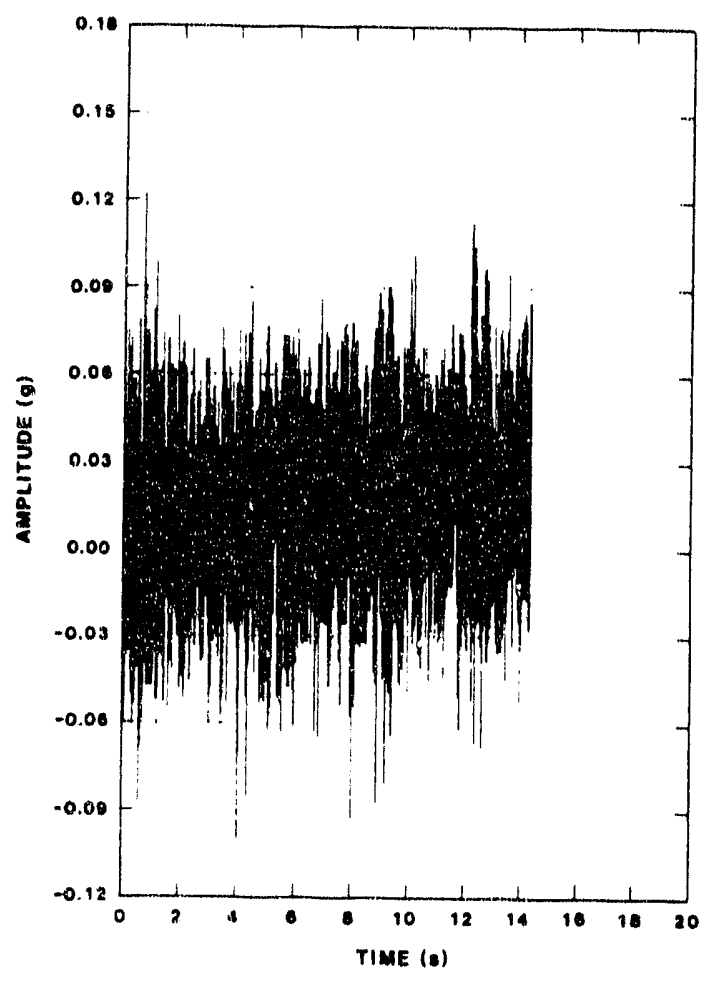

Figure A11. Road rest-CNS 14.170-1 Cask (Test 1) Rear Longitudinal Loc 16 , Smooth Asphrit

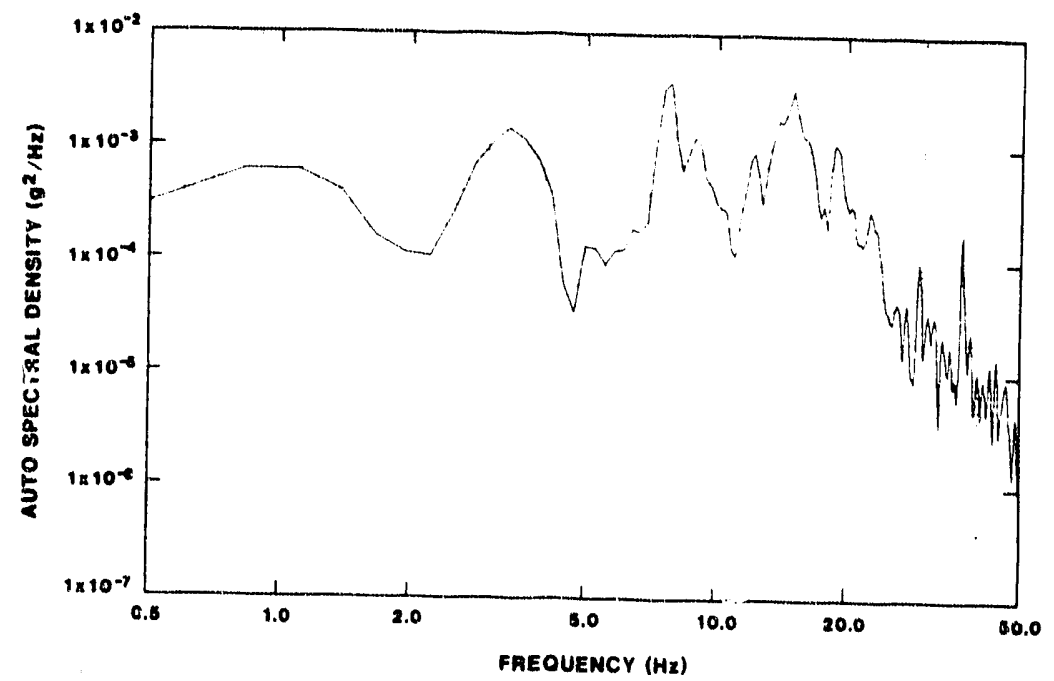

Figure A10. Road Test-CNS 14-170-1 Cask (Test y) Rear Vortical Loc. 5 ; Smooth Asphalt

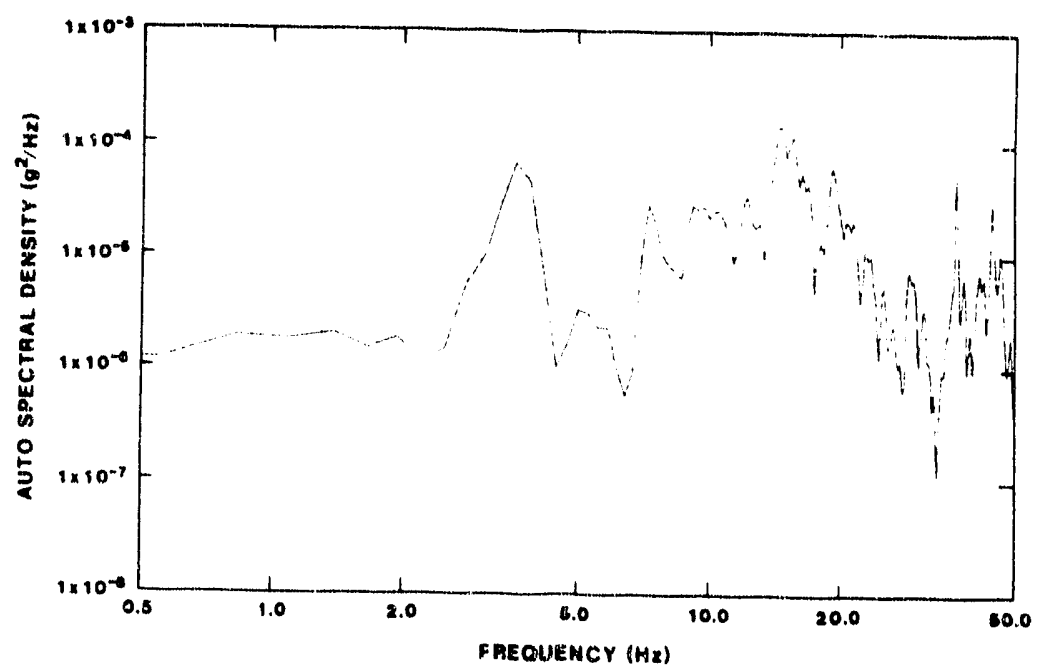

Figure A12. Poad Test-CNS 14-170.1 Cask (Test 1) Rear Longitudinal L.oc. "66; Smooth Asphalt 


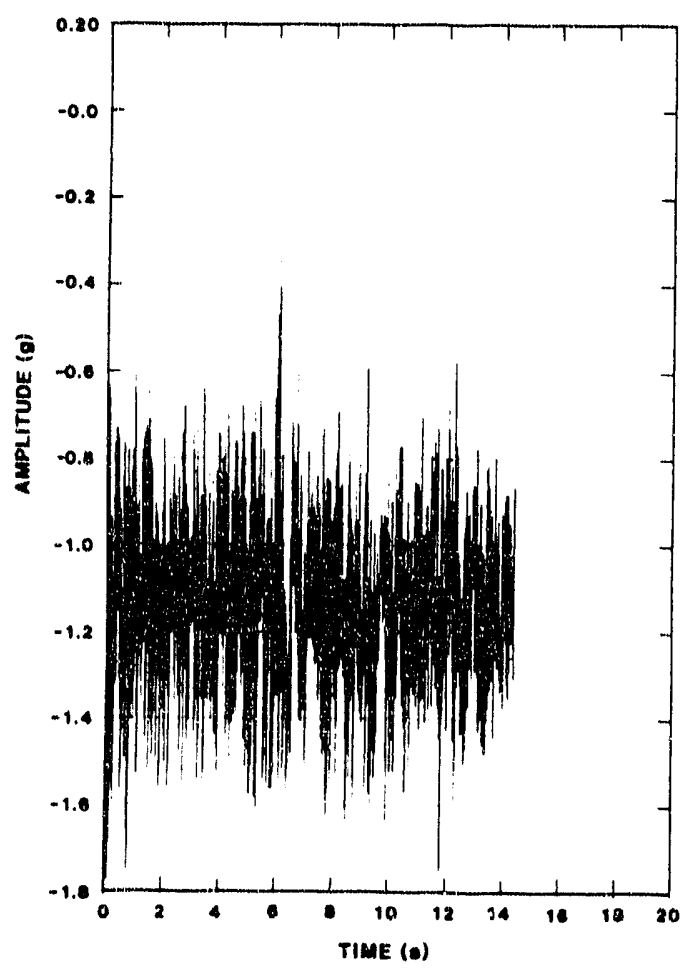

Figure A13. Road Test-CNS 14-170.1 Cask (Test 1) Front Vertical LoC 17; Smooth Asphalt

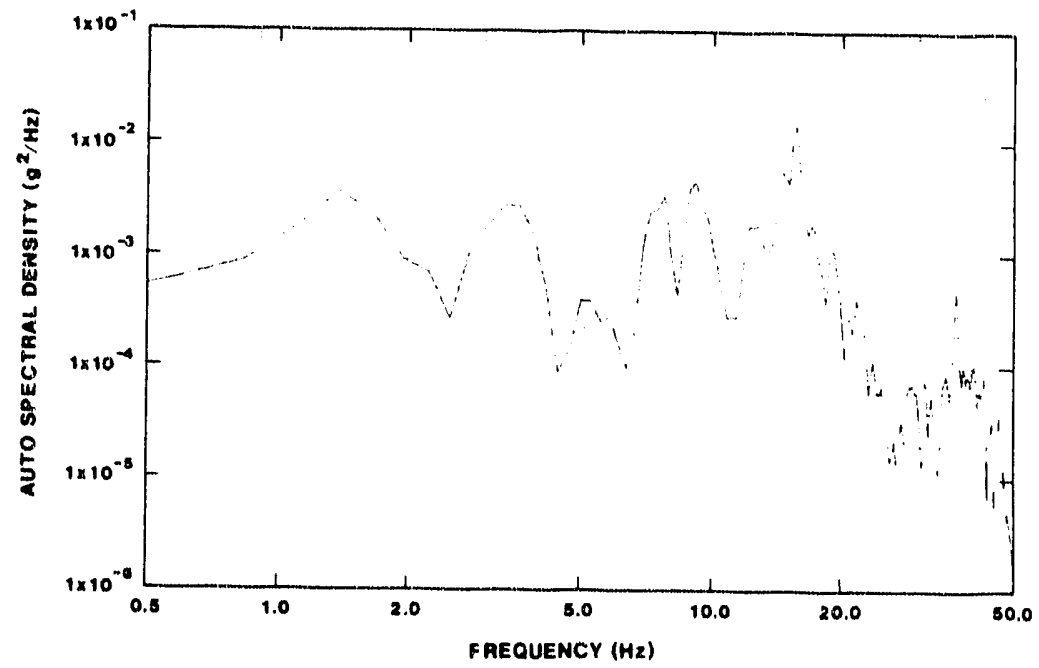

Figure A14. Road Test-CNS 14-170-1 Cask (Test 1) Front Vertical Loc. "7; Smooth Asphalt 


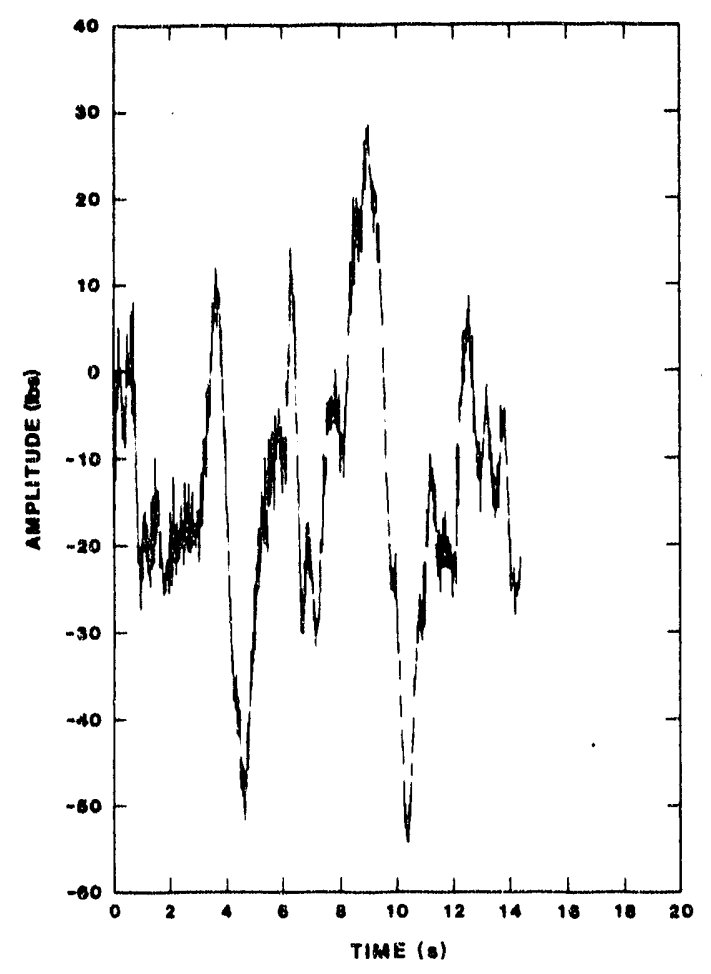

Figure A15. Foad Test-CNS 14-170-1 Cask (Test 1) Front Load Cell Loc. \#13; Smooth Asphalt

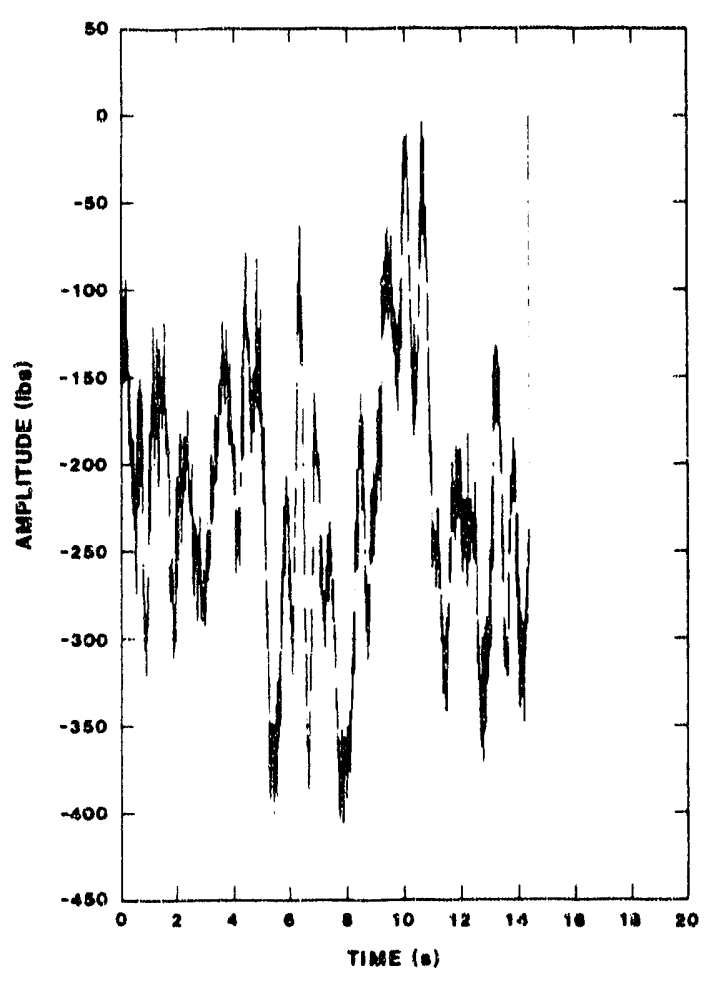

Figure A17. Road Test-CNS 14-170-1 Cask (Test 1) Rear Load Cell LoC. 14: Smooth Asphalt

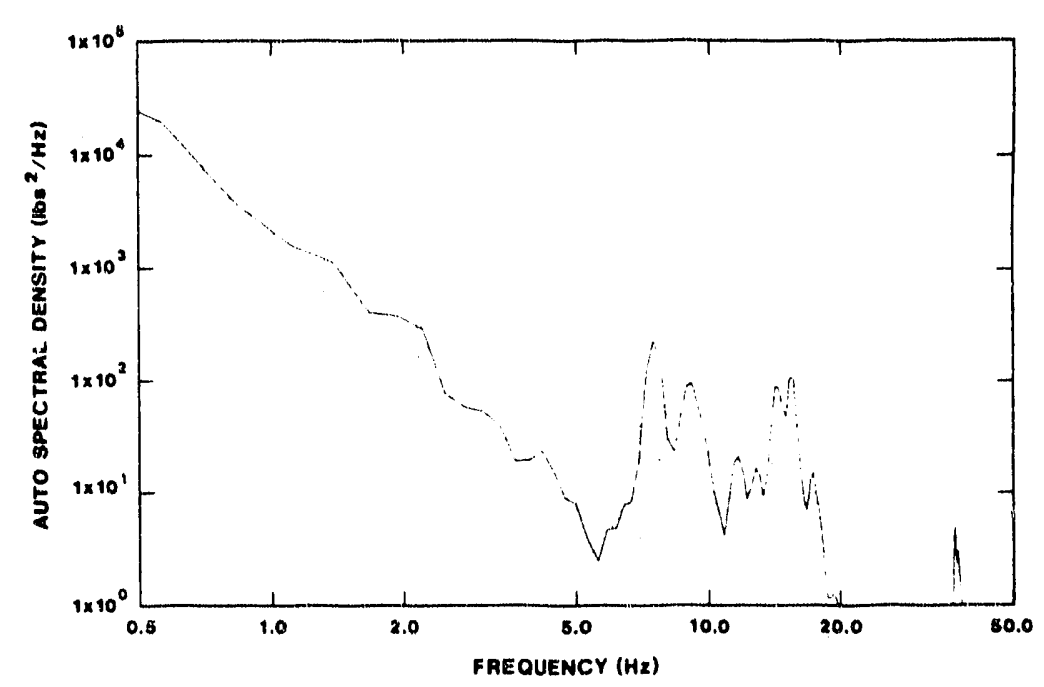

Figure A 16. Road Test-CNS 14-170-1 Cask (Test 1) Front Load Cell Loc. 13; Smooth Asphalt

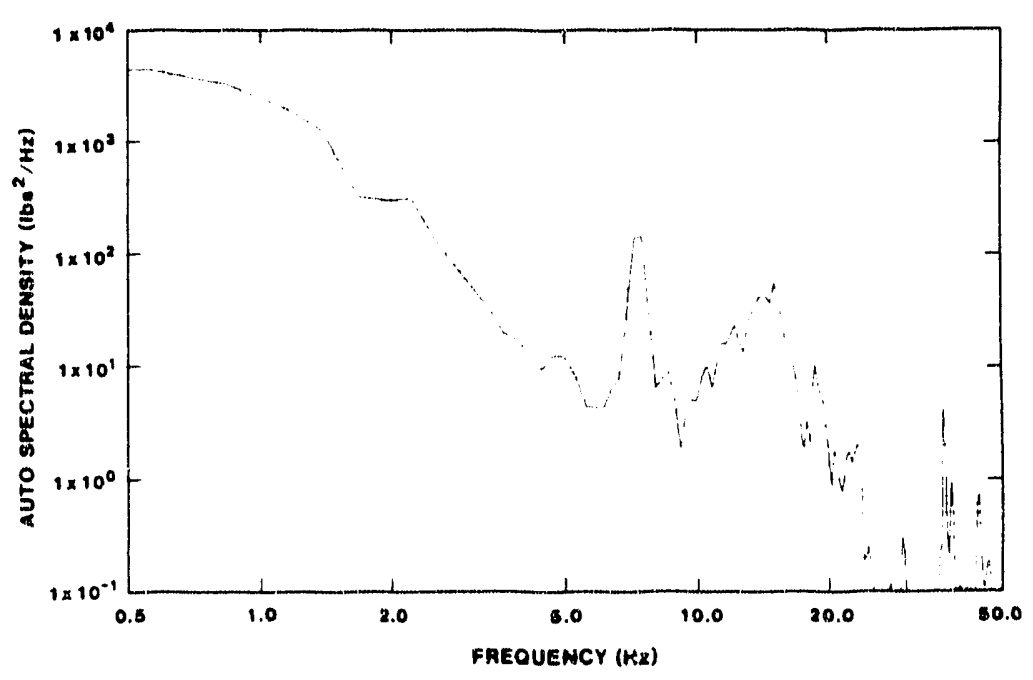

Figure A18. Road Test-CNS 14-170-1 Cask (Test 1) Rear Load Cell Loc. "14; Smooth Asphalk 


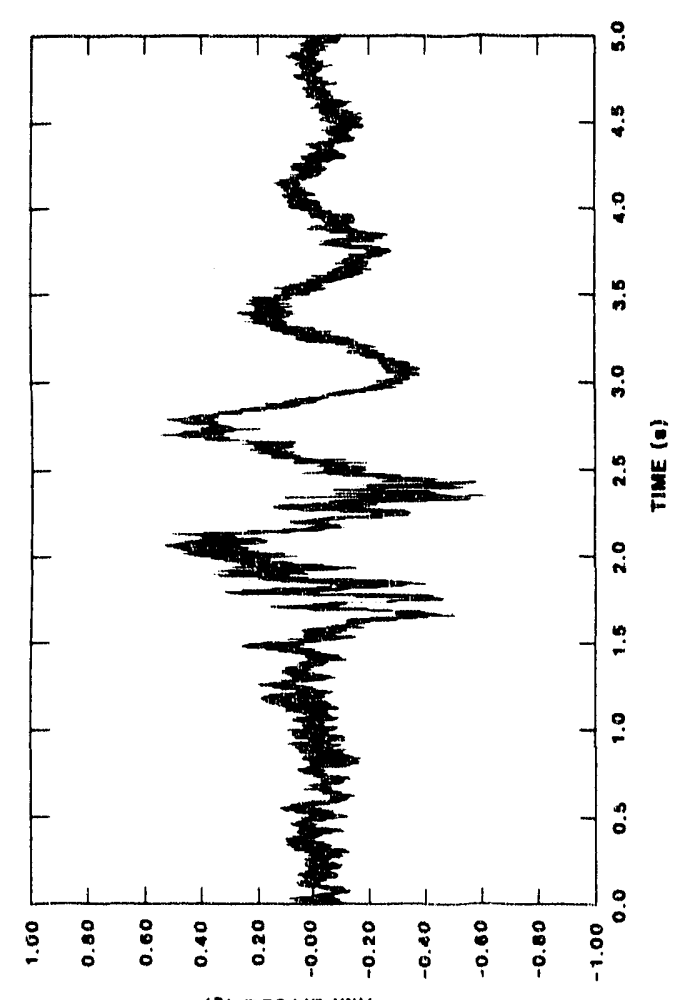

(b) zandindwr

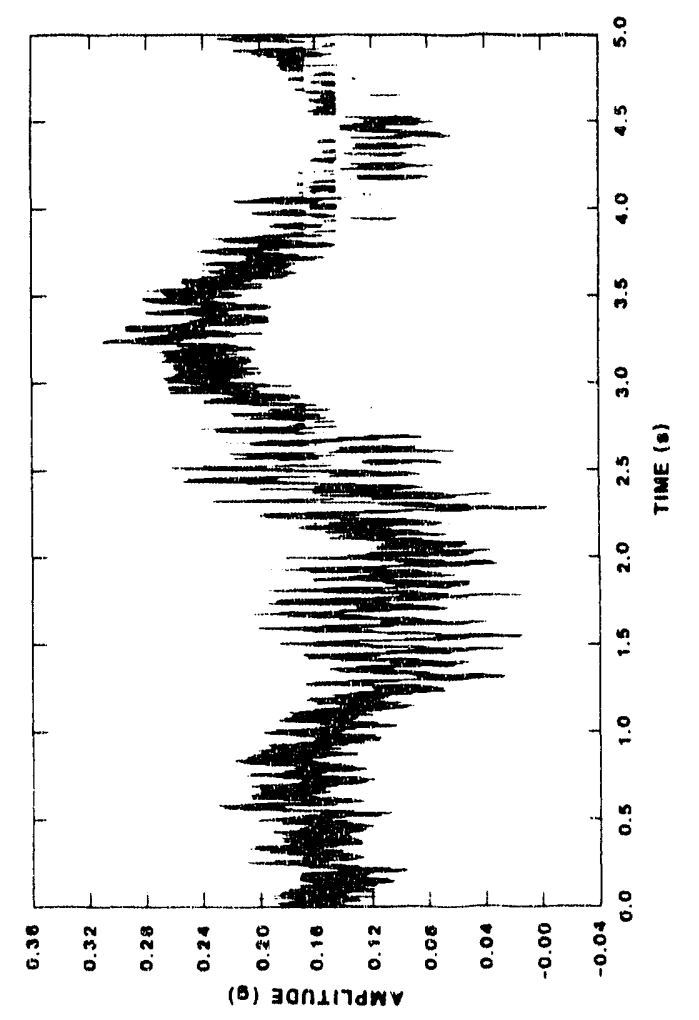

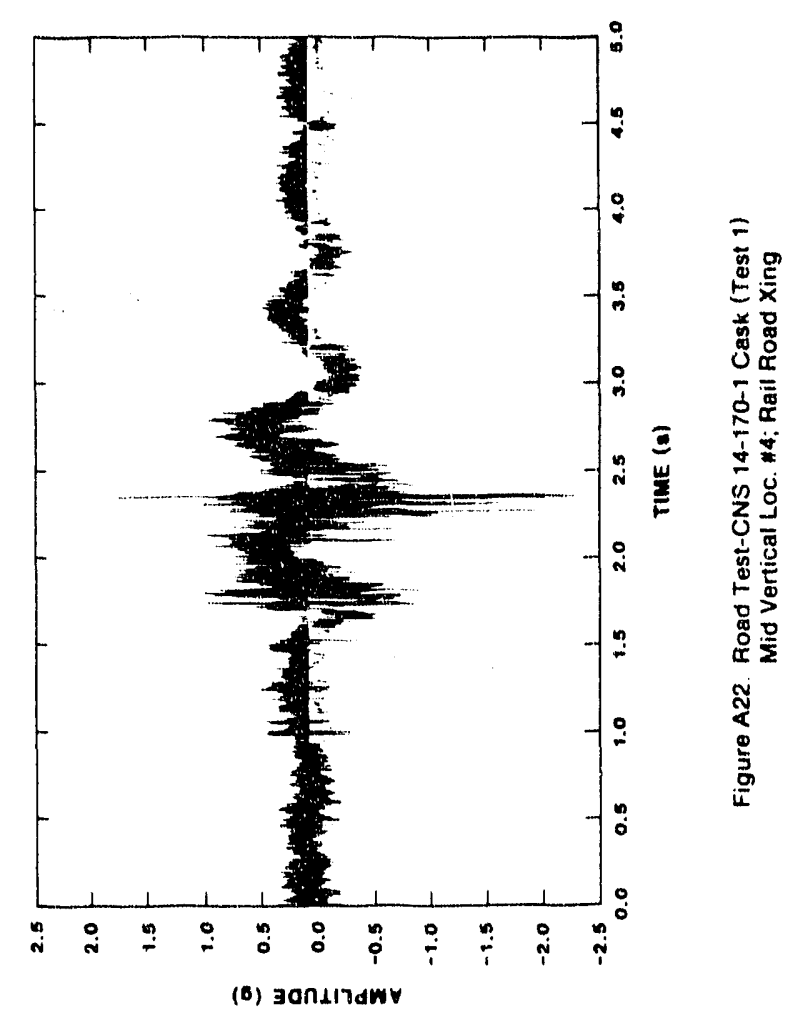

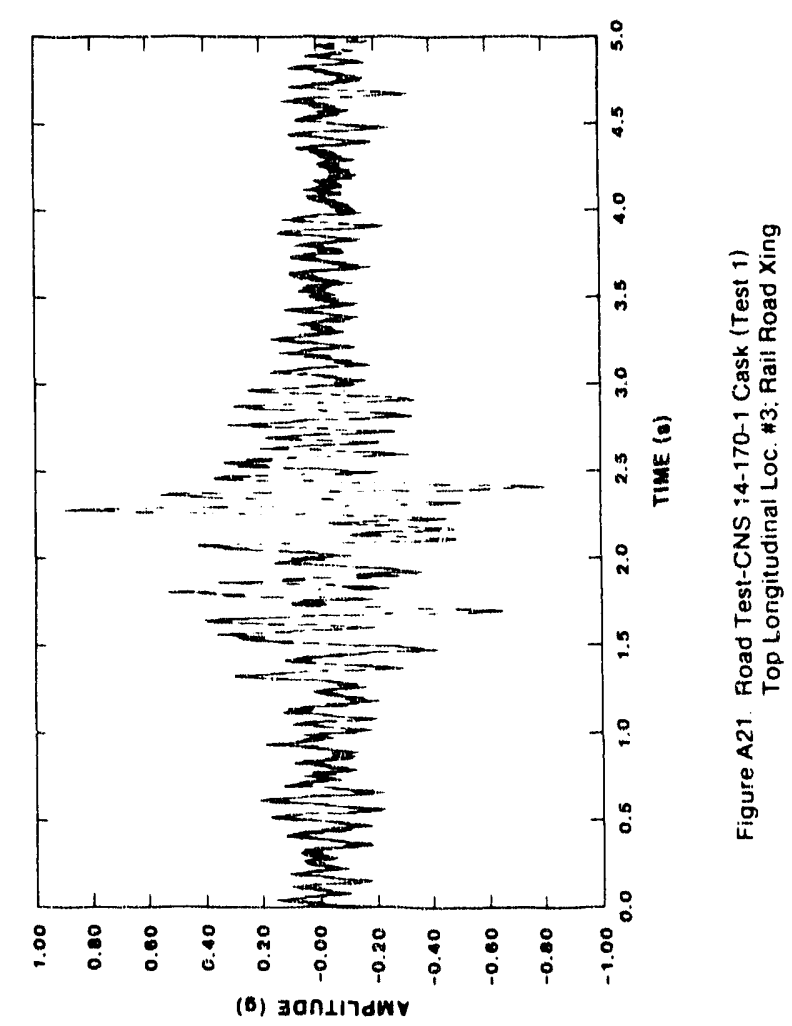



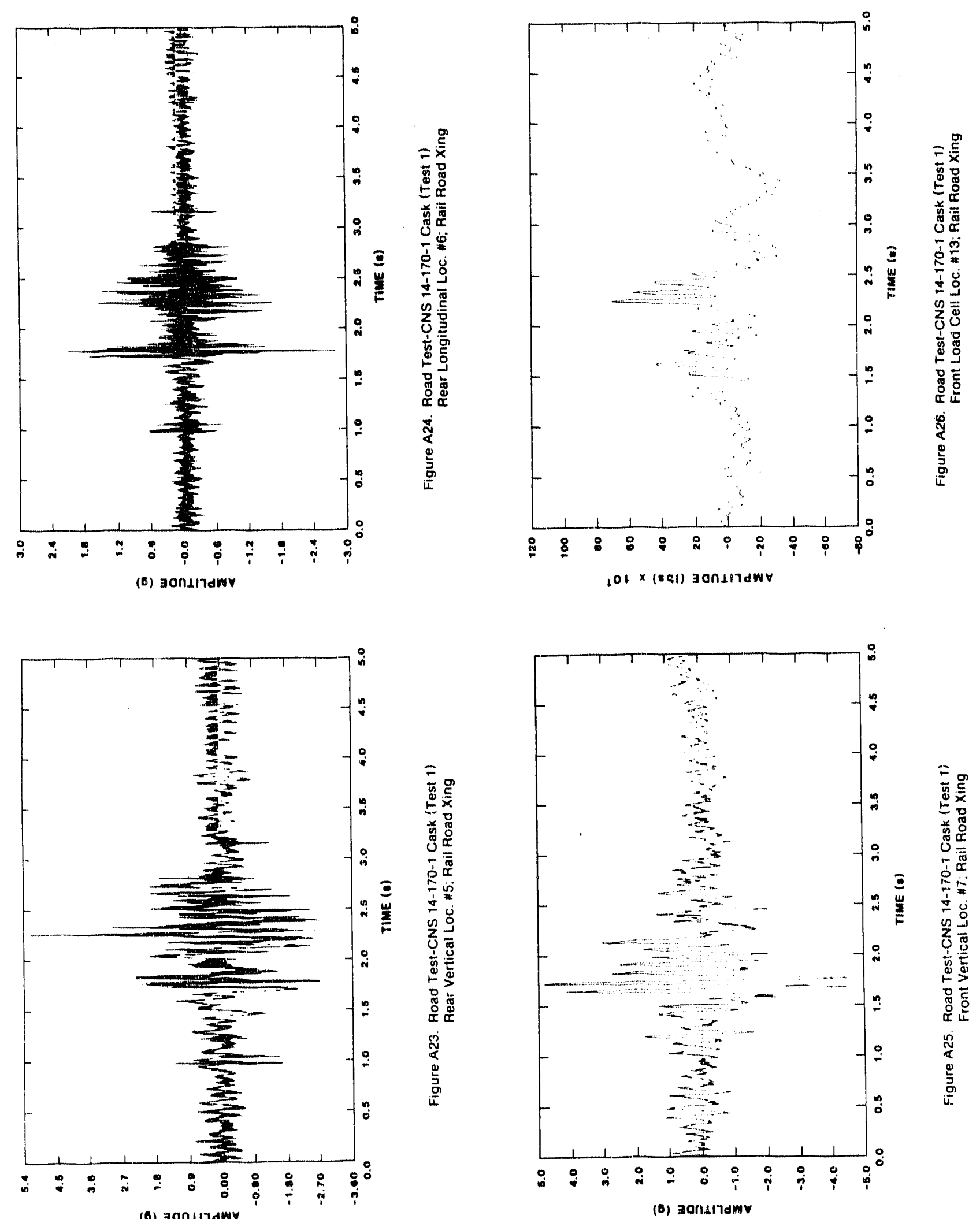

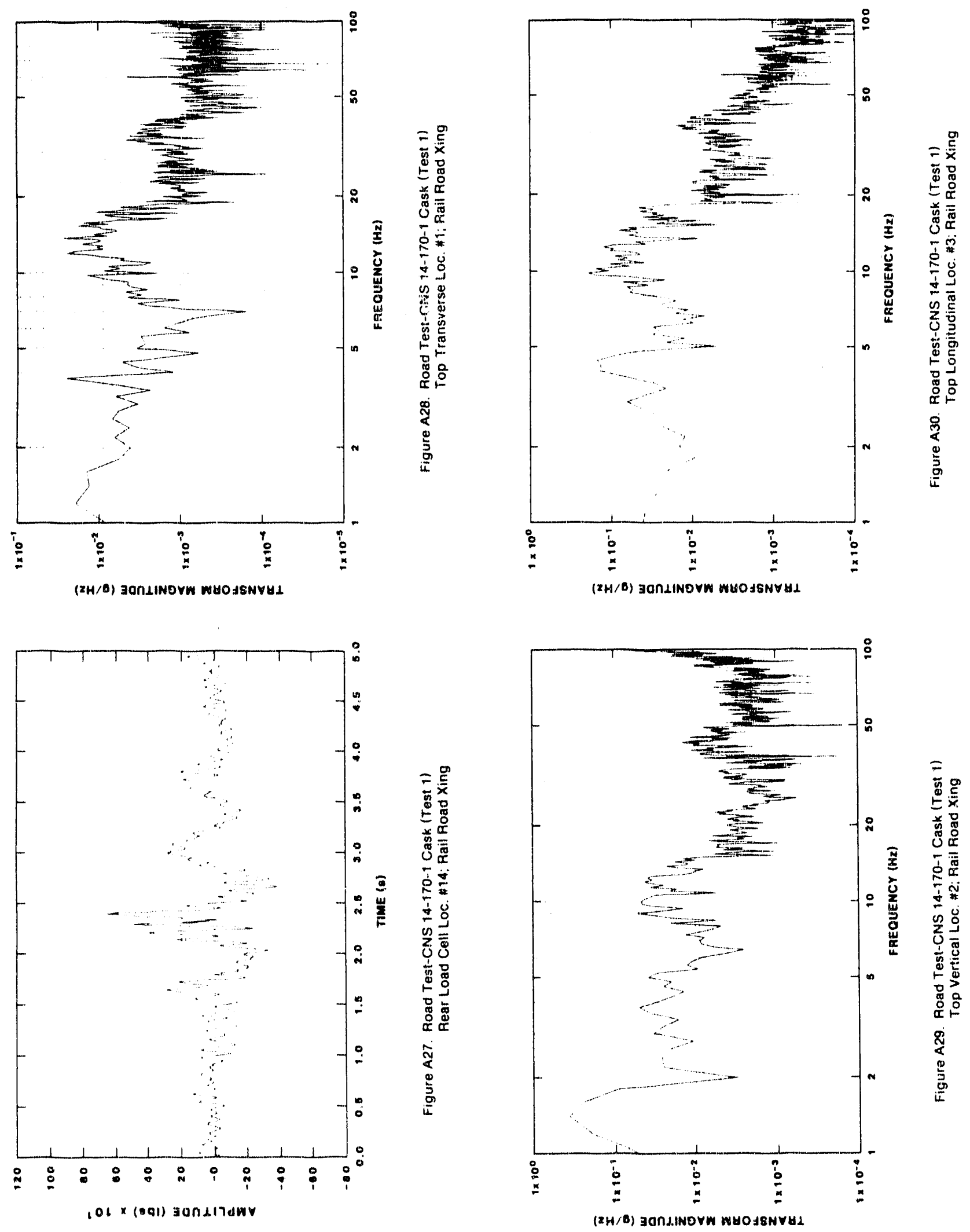

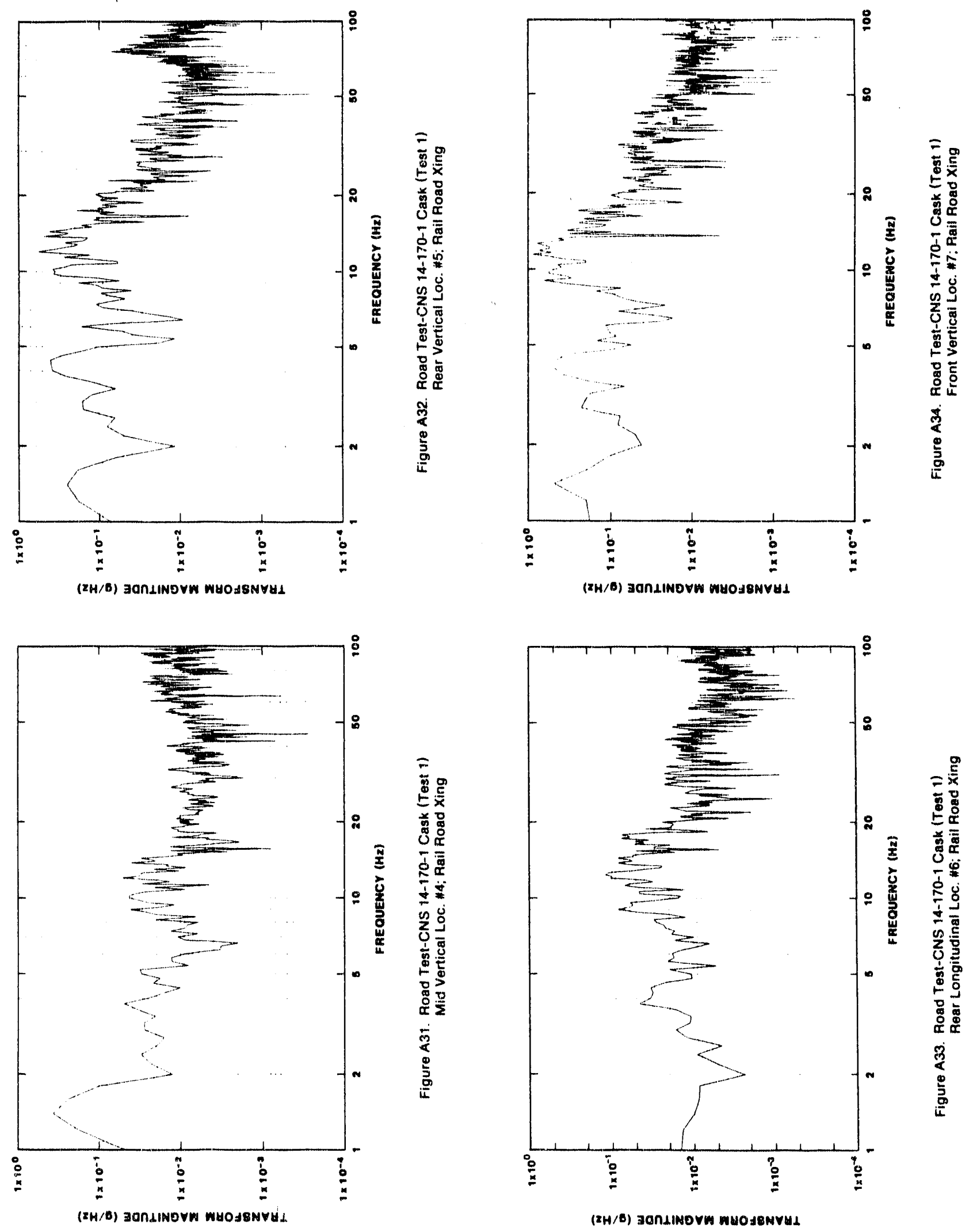

(2H/O) BONLINOVW MUOABNVYL 


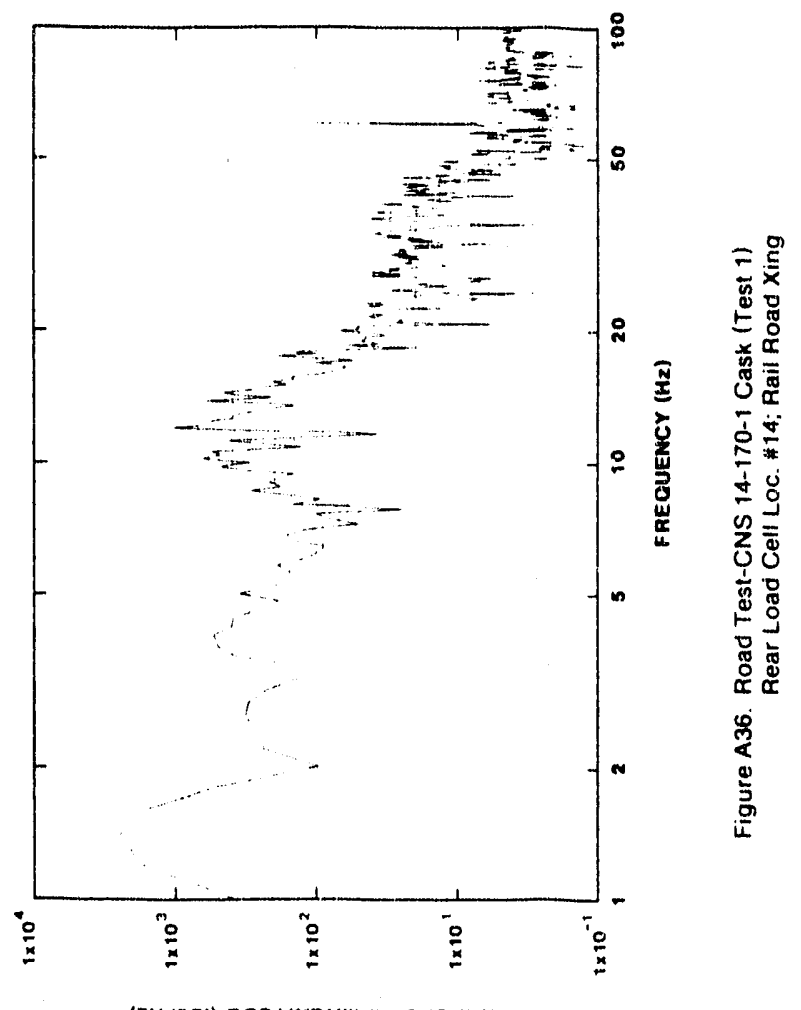

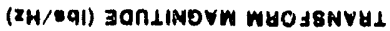

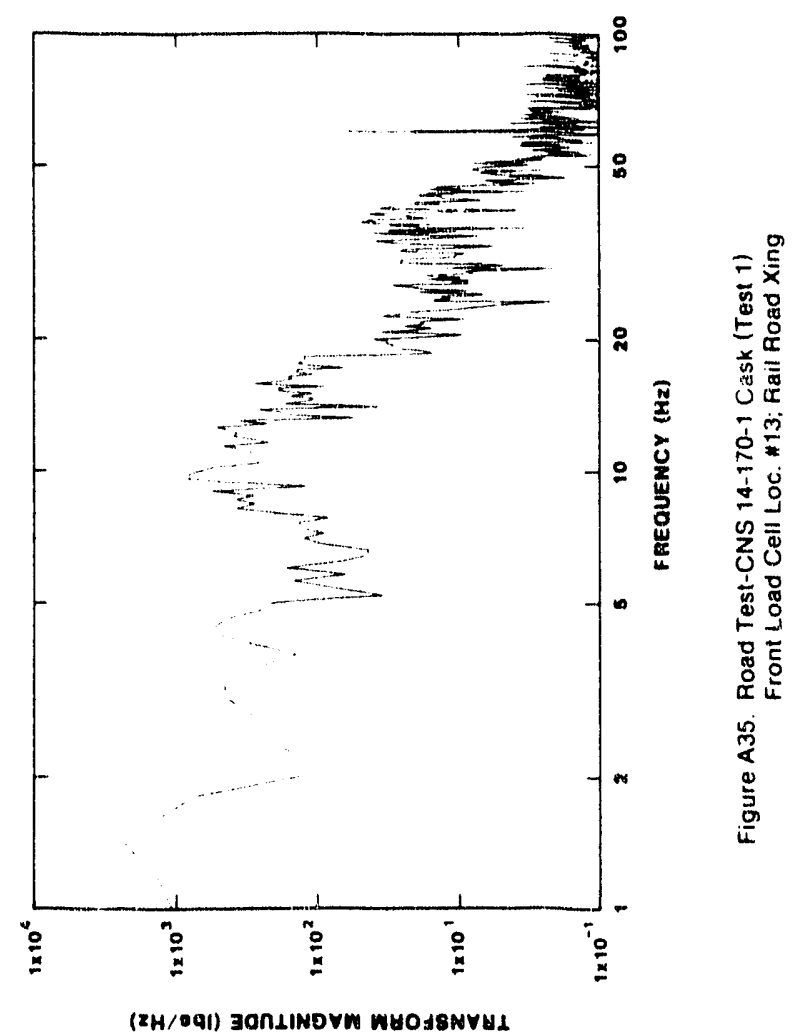




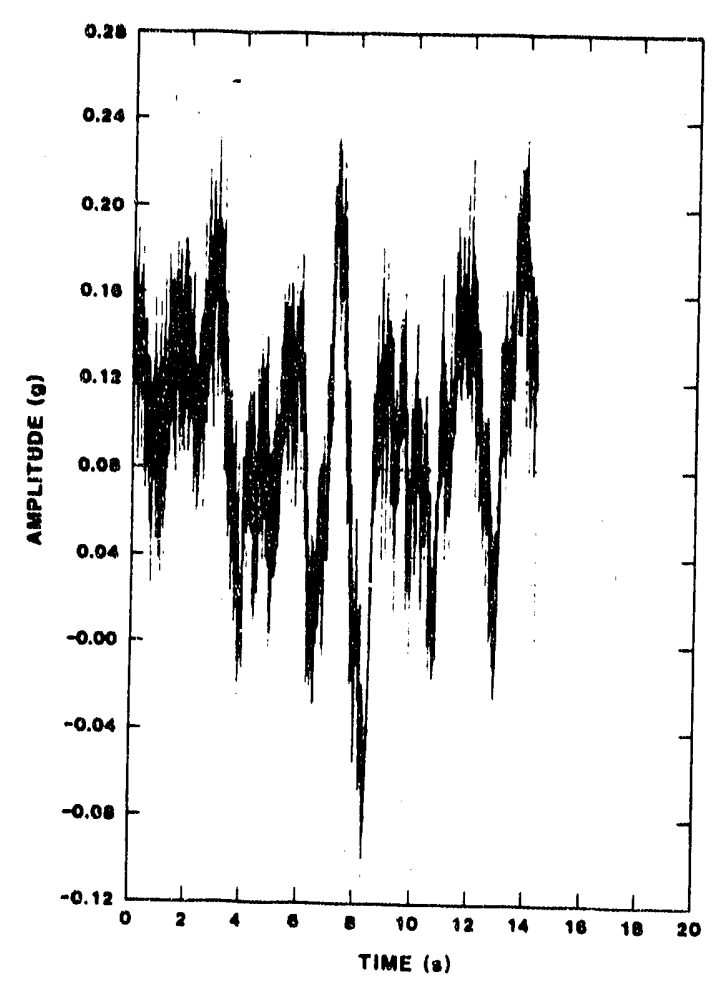

Figure A37. Road Test-CNS 14-170-1 Cask (Test 1) Top Transverse Loc. \#1; Rough Asphalt

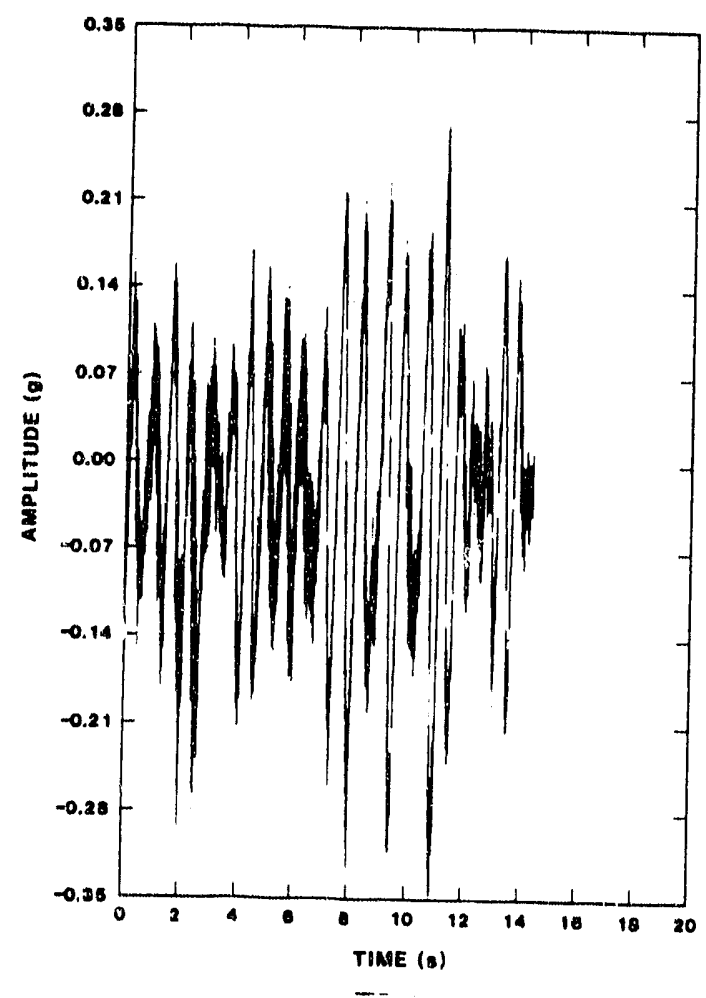

Figure A39. Road Test-CNS 14-170-1 Cask (Test 1) Top Vertical Loc. N2; Rough Asphalt

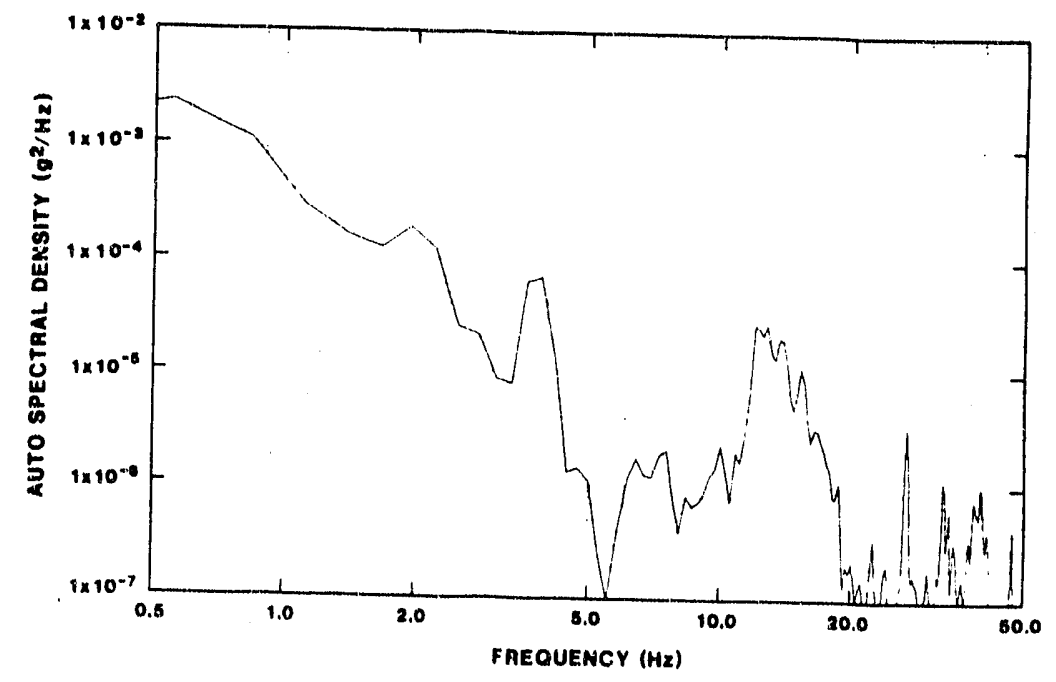

Figure A38. Road Test-CNS 14-170-1 Cask (Test 1) Top Transverse Loc. \#1; Rough Asphait

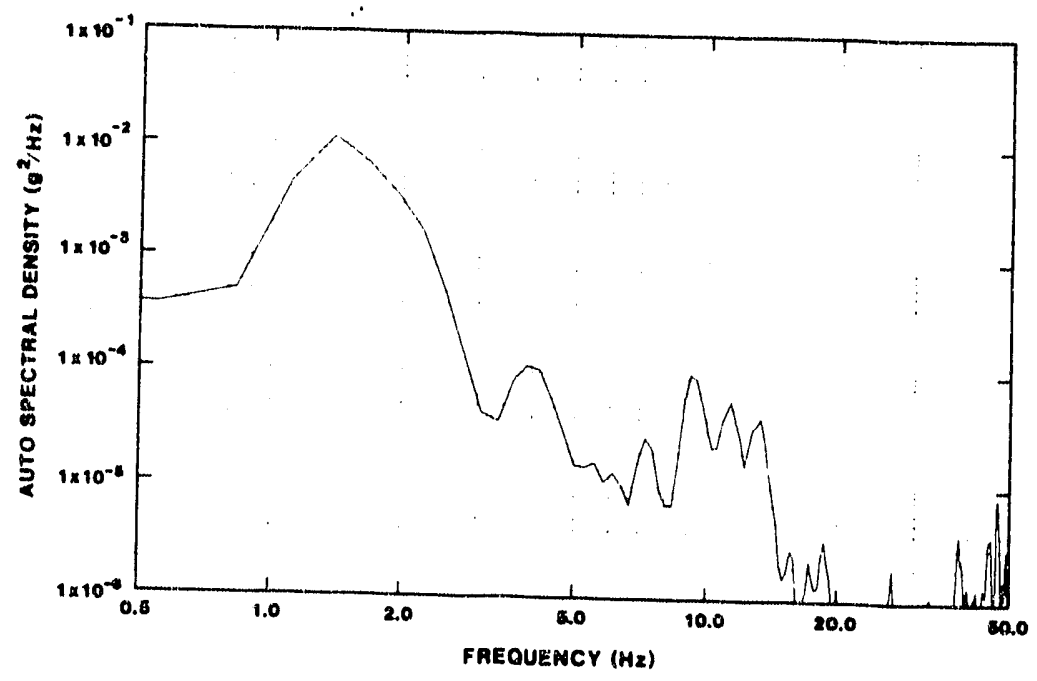

Figure A40. Road Test-CNS 14-170-1 Cask (Test 1) Top Vertical LOC. 2; Rough Asphalit 


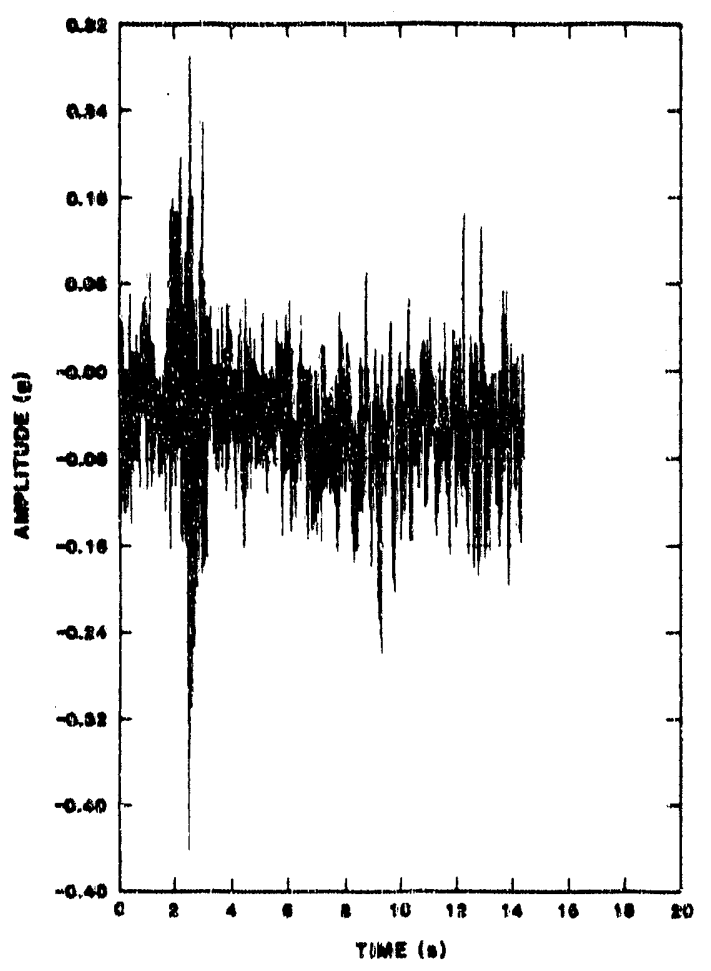

Figure A41. Rosd Tost-CNS 14-170-1 Cask (Test 1) Top Longitudinal LOC. 33: Rough Asphult

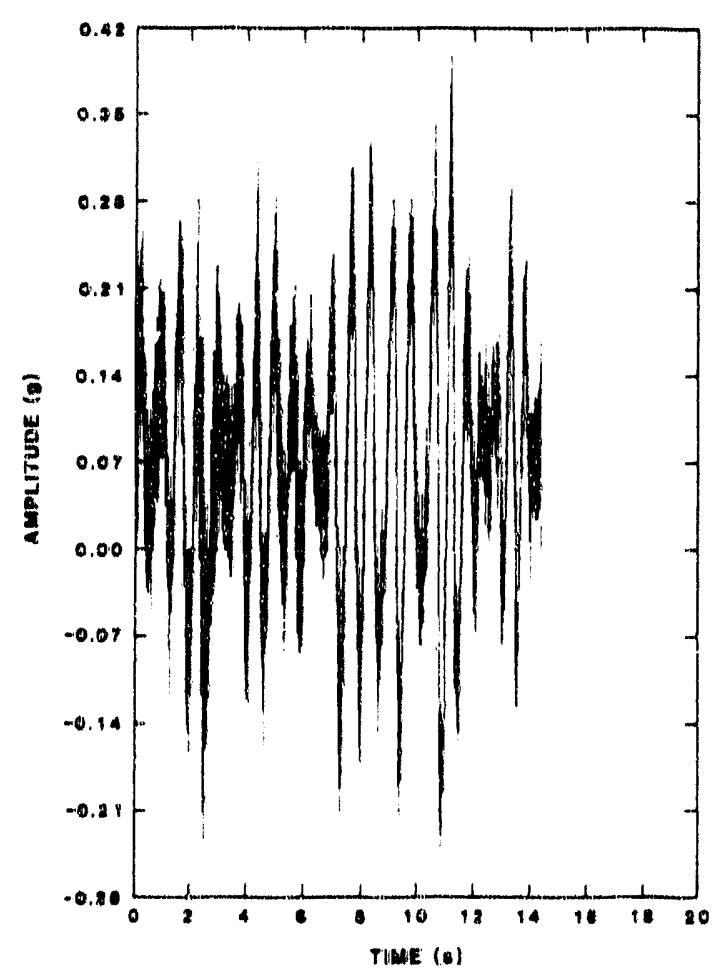

Figure A43. Row Tesp-CNS 14-170-1 Cark (Test 1) Mid Vortical Loc. HA; Rough Asphalt

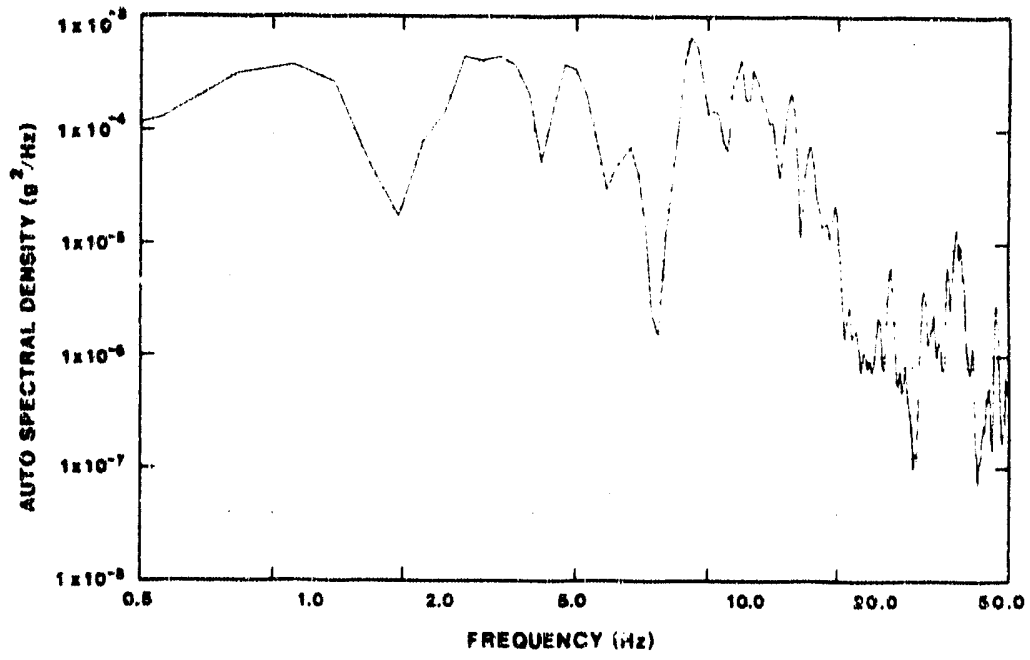

Figure A42. Ro8d Test-CNS 14-170-1 Cask (Test 1) Top Longitudinal LoC. 13; Rough Asphalt

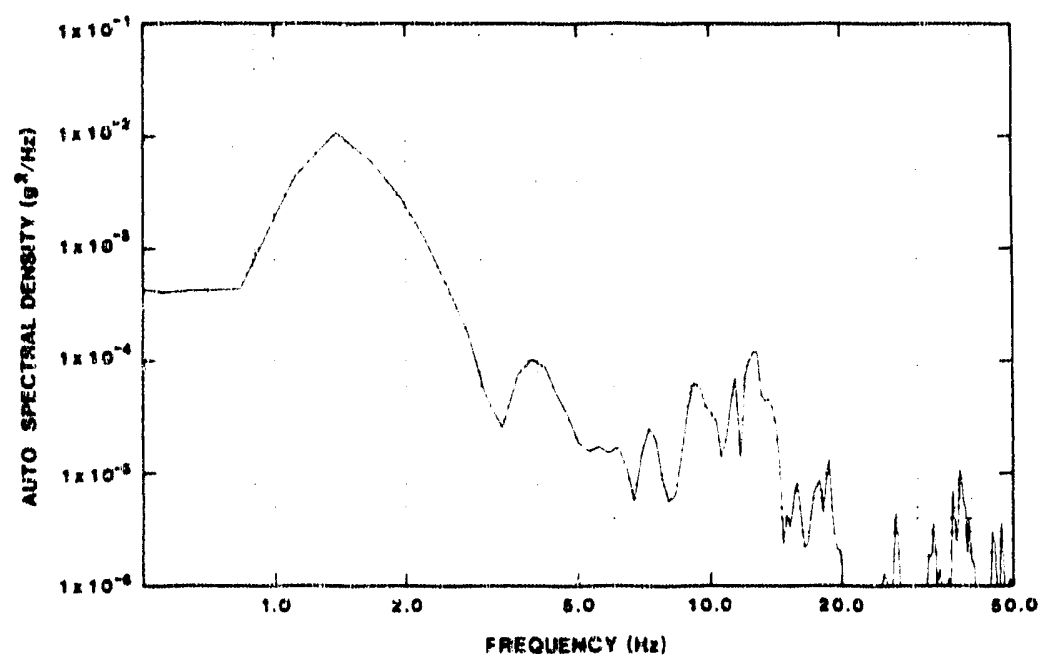

Figure A44. Road Test-CNS 14-170-1 Cask (Test 1) Mid Verticil Loc. MA: Rough Asphait 


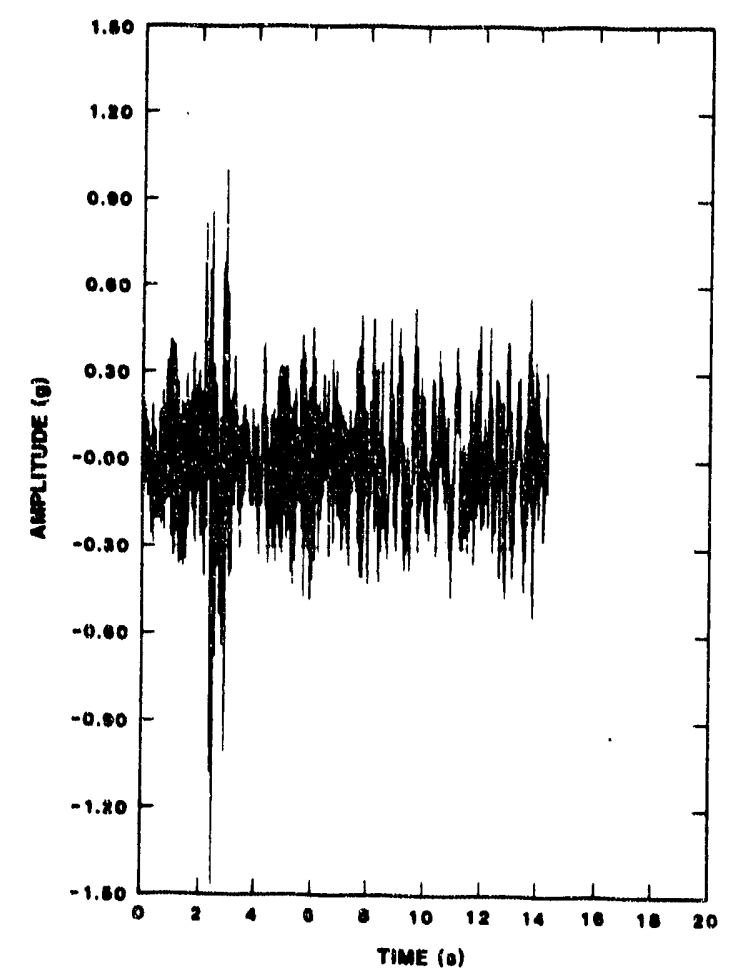

Figure A45. Road Test-CNS 14-170-1 Cask (Test 1) Rear Vortical Loc. 5 ; Rough Asphalt

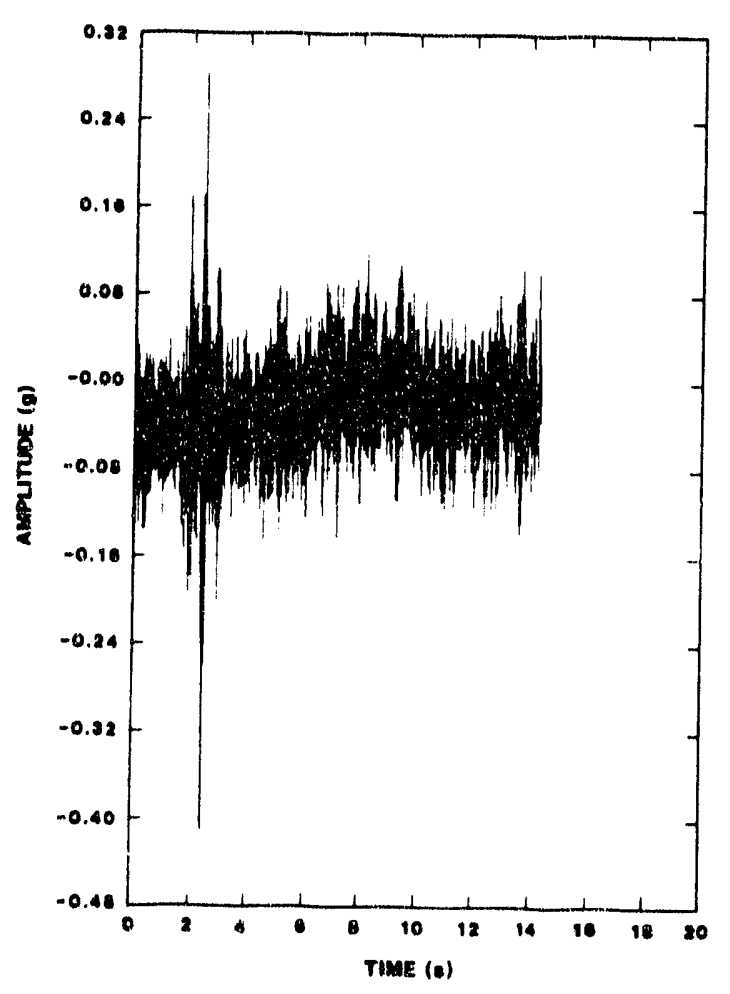

Figuro A47. Rosd Tost-CNS 14-170-1 Cask (Test 1) Rear Longitudinal Loc. w6; Aough Asphalt

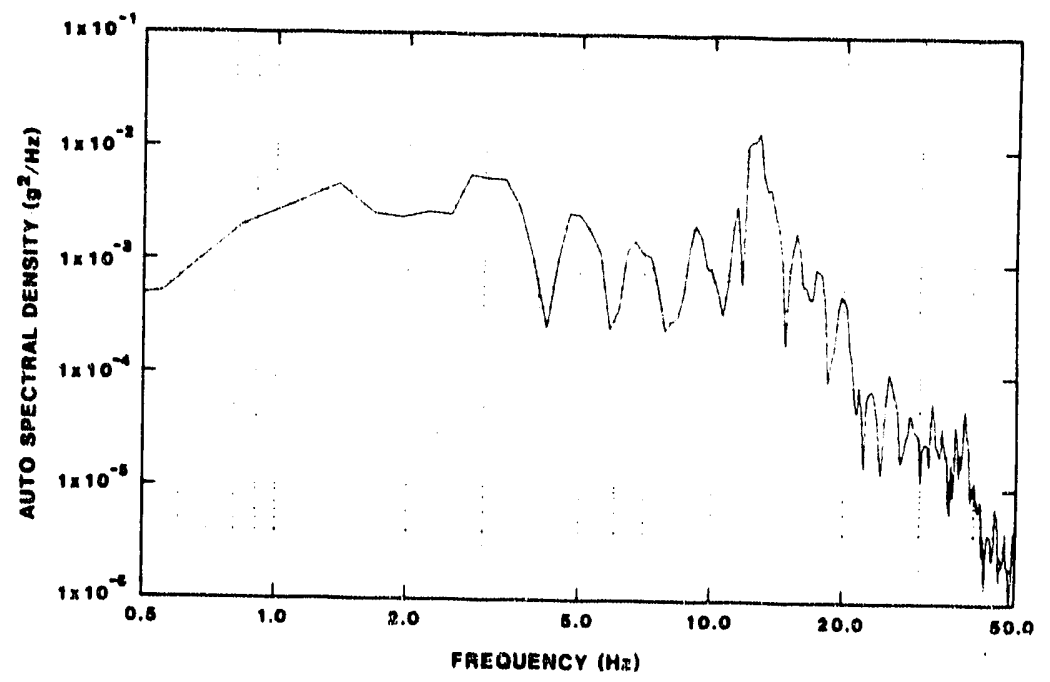

Figure A46. Road Test-CNS 14-170-1 Cask (Test 1) Rear Vertical Loc. "5; Rough Asphalt

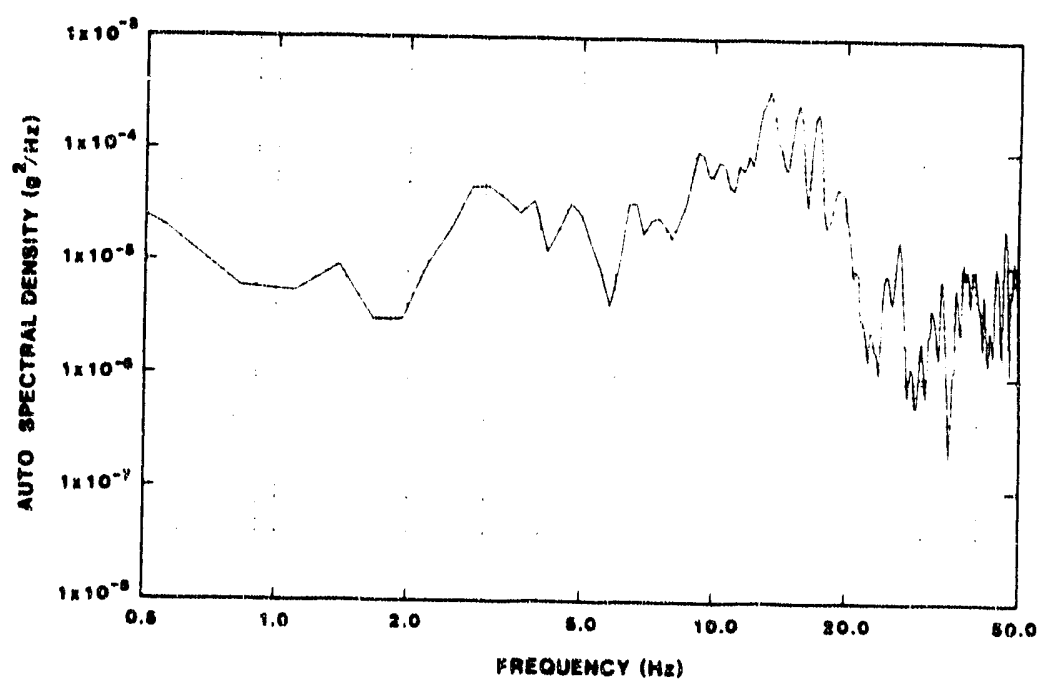

Figure A48. Road Test-CNS 14-170-1 Cask (Tost 1) Rear Longltudinal Loc. \#6; Fough Asphalt 


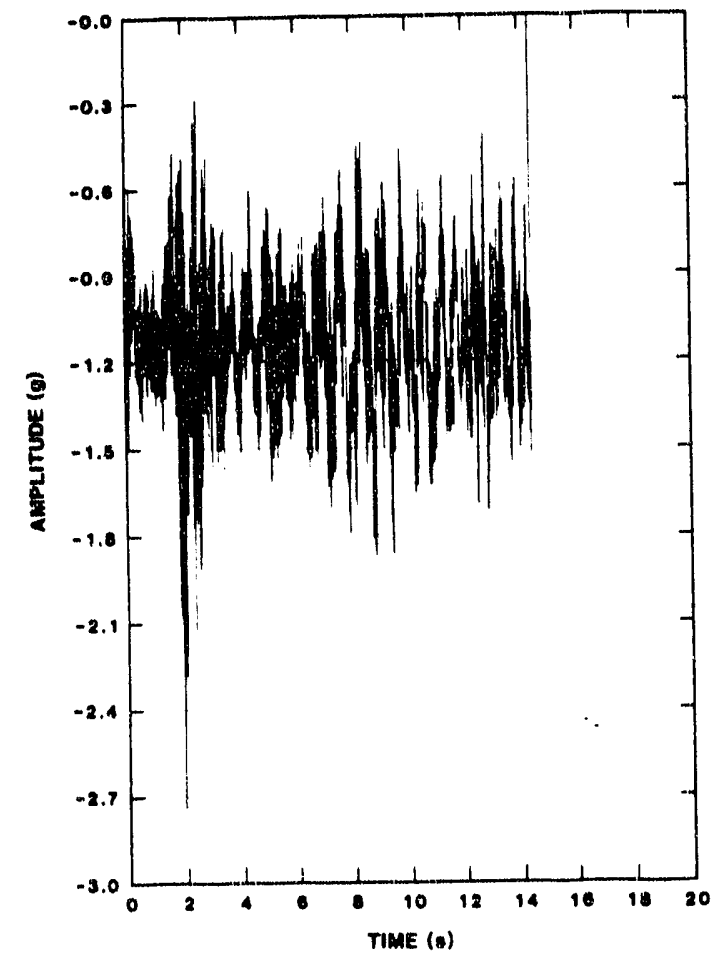

Figure A49. Road Test-CNS 14-170-1 Cask (Test 1) Front Vertical Loc. \#7; Rough Asphalt

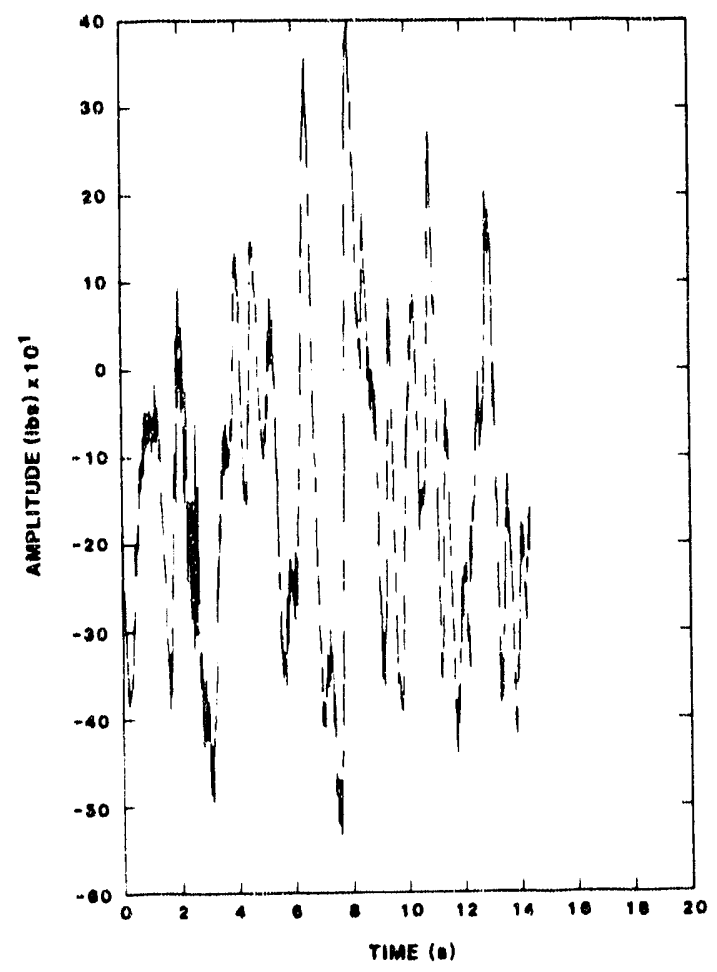

Figure A51. Roed Test-CNS 14-170-1 Cask (Test 1) Front Load Call LoC. 13: Pough Asphait

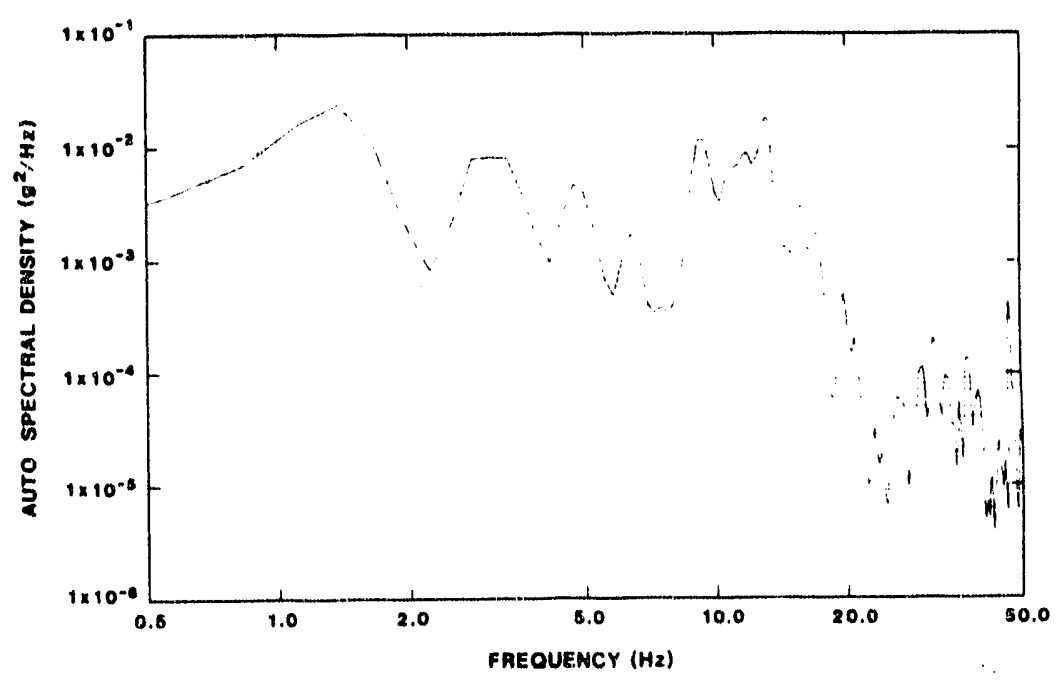

Figure A50. Road Test-CNS 14-170-1 Cask (Test 1) Front Vertical Loc. \#7; Pough Asphalt

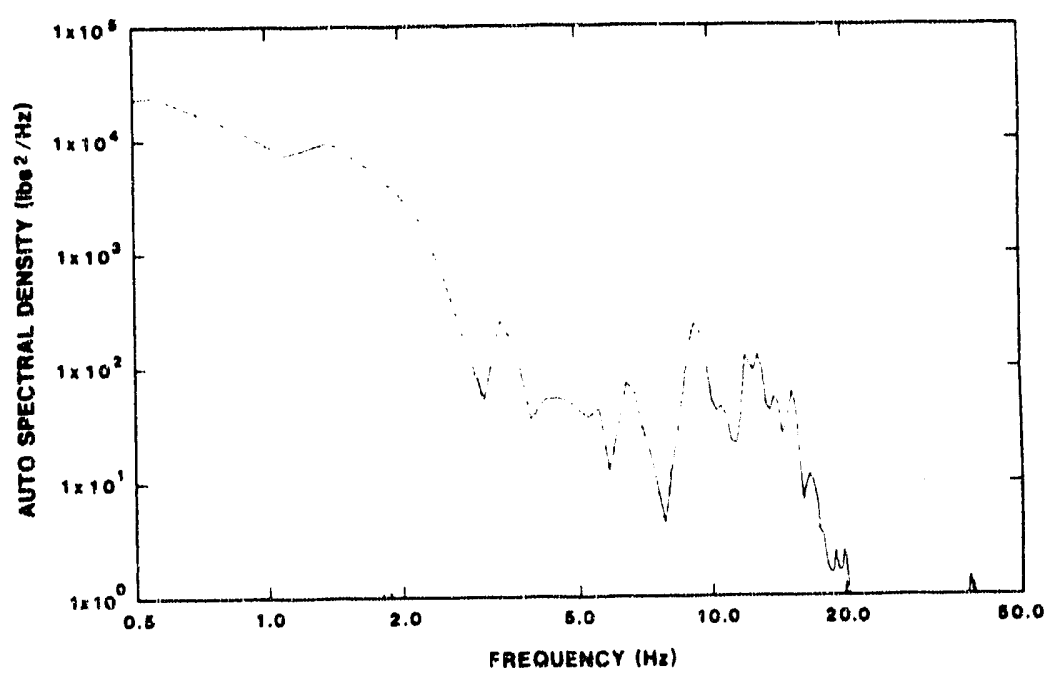

Figure A52. Rosd Test-CNS 14-170-1 Cask (Test 1)

Front Load Cell LoC. 13; Rough Asphalt 


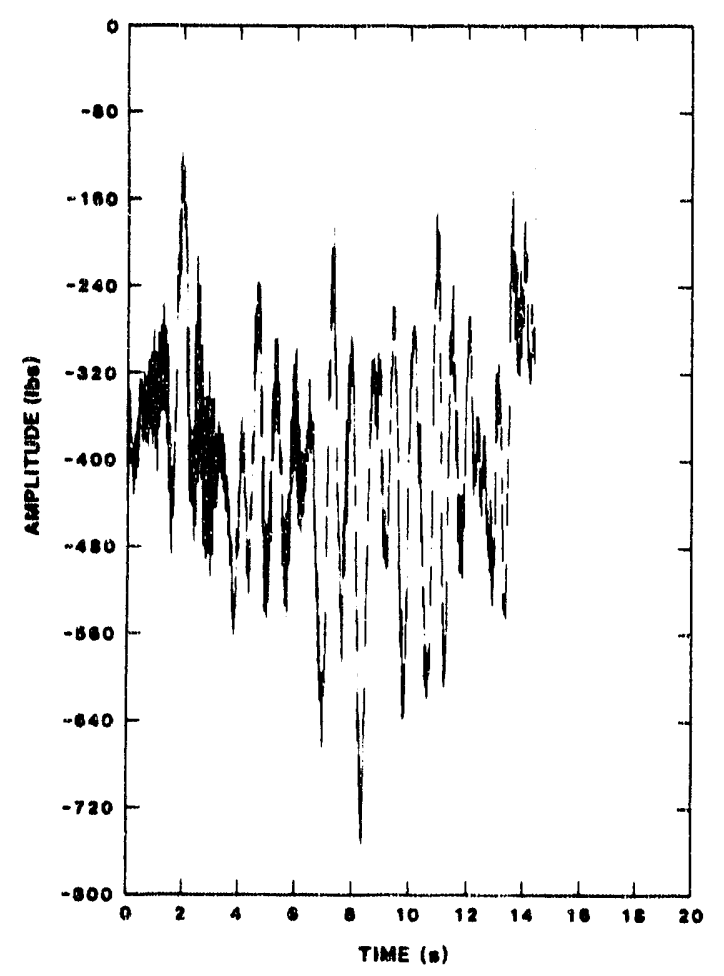

Figure A53. Road Tost-CNS 14-170-1 Cask (Test 1) Rear Load Cell Loc. 14; Rough Asphalt

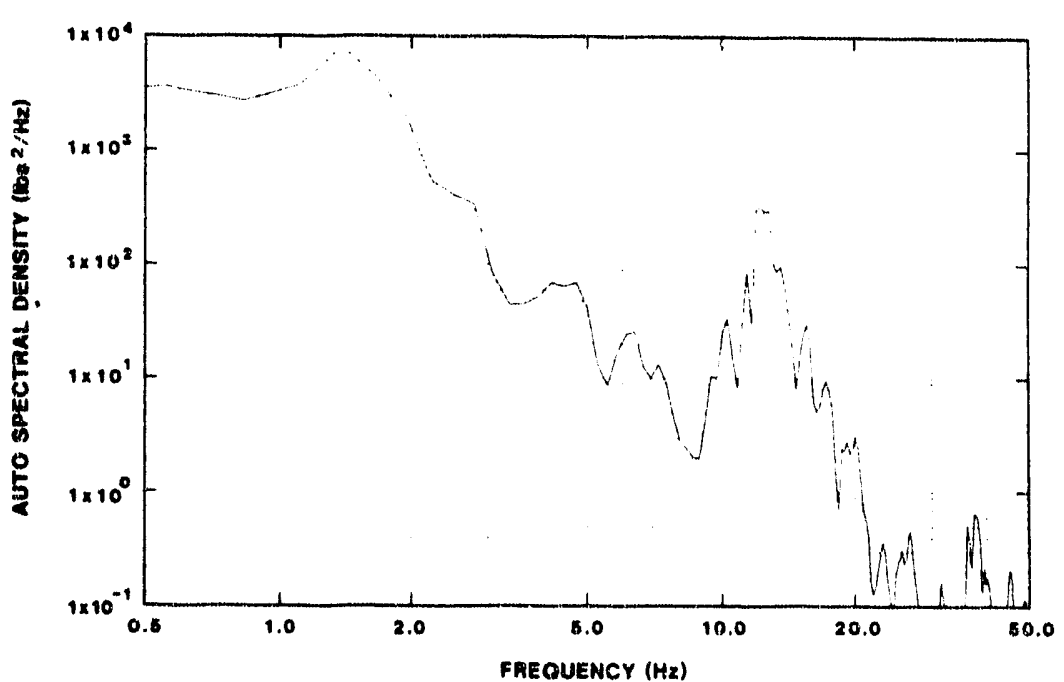

Figure A54. Road Test-CNS 14-170-1 Cask (Test 1)

Rear Lood Cell Loc. 14; Rough Asphalt 


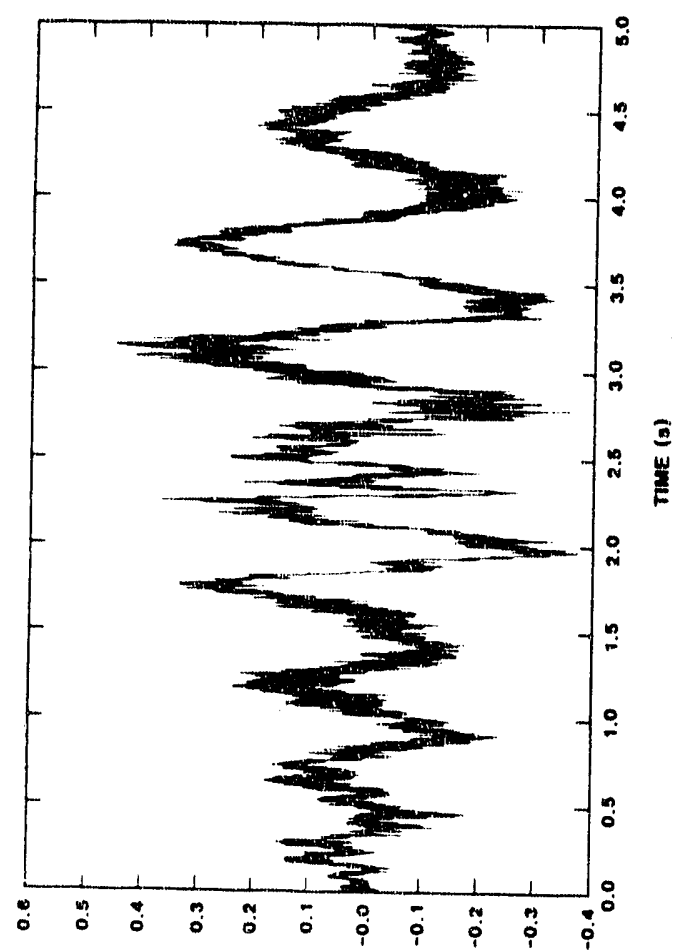

(5) Jolnsl7awr

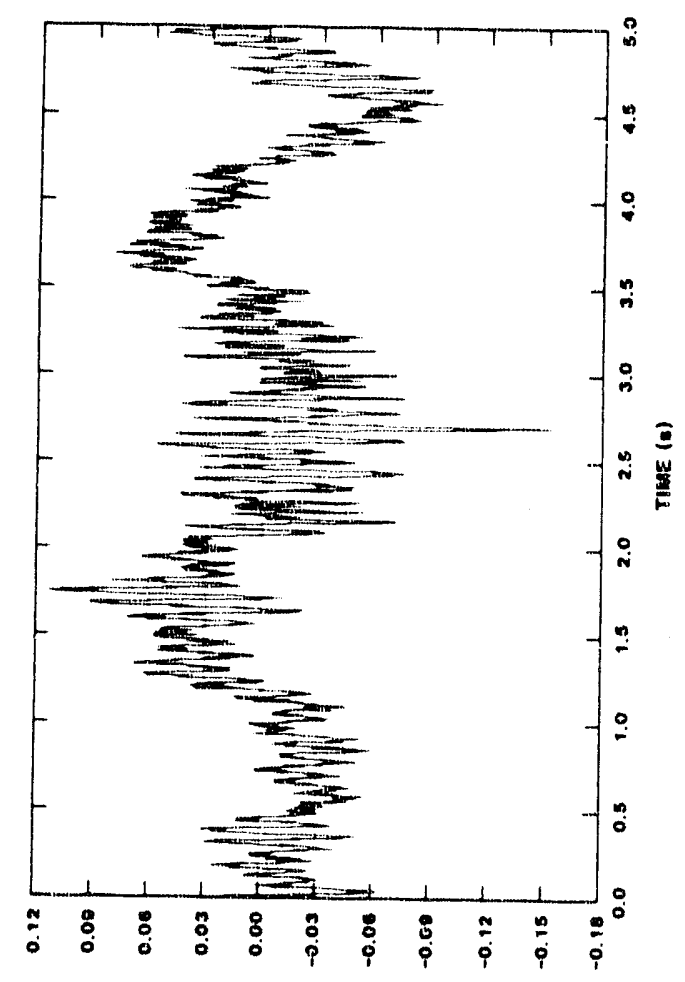

(b) zondl7awv

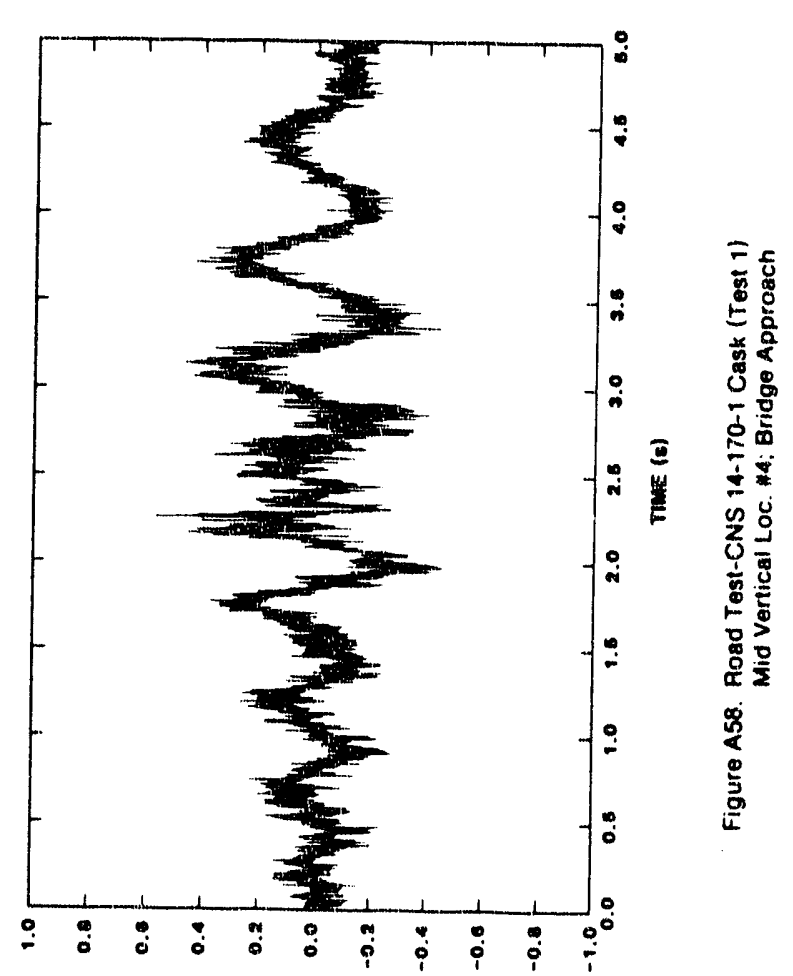

(B) gonulzawy

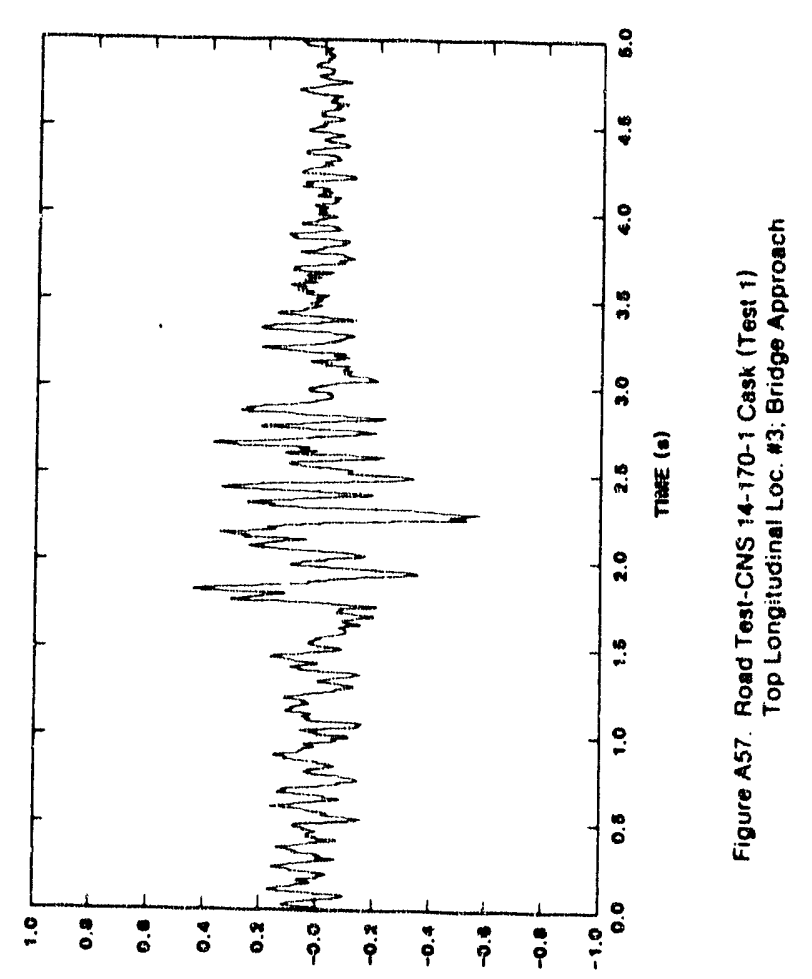

(B) manundwr 

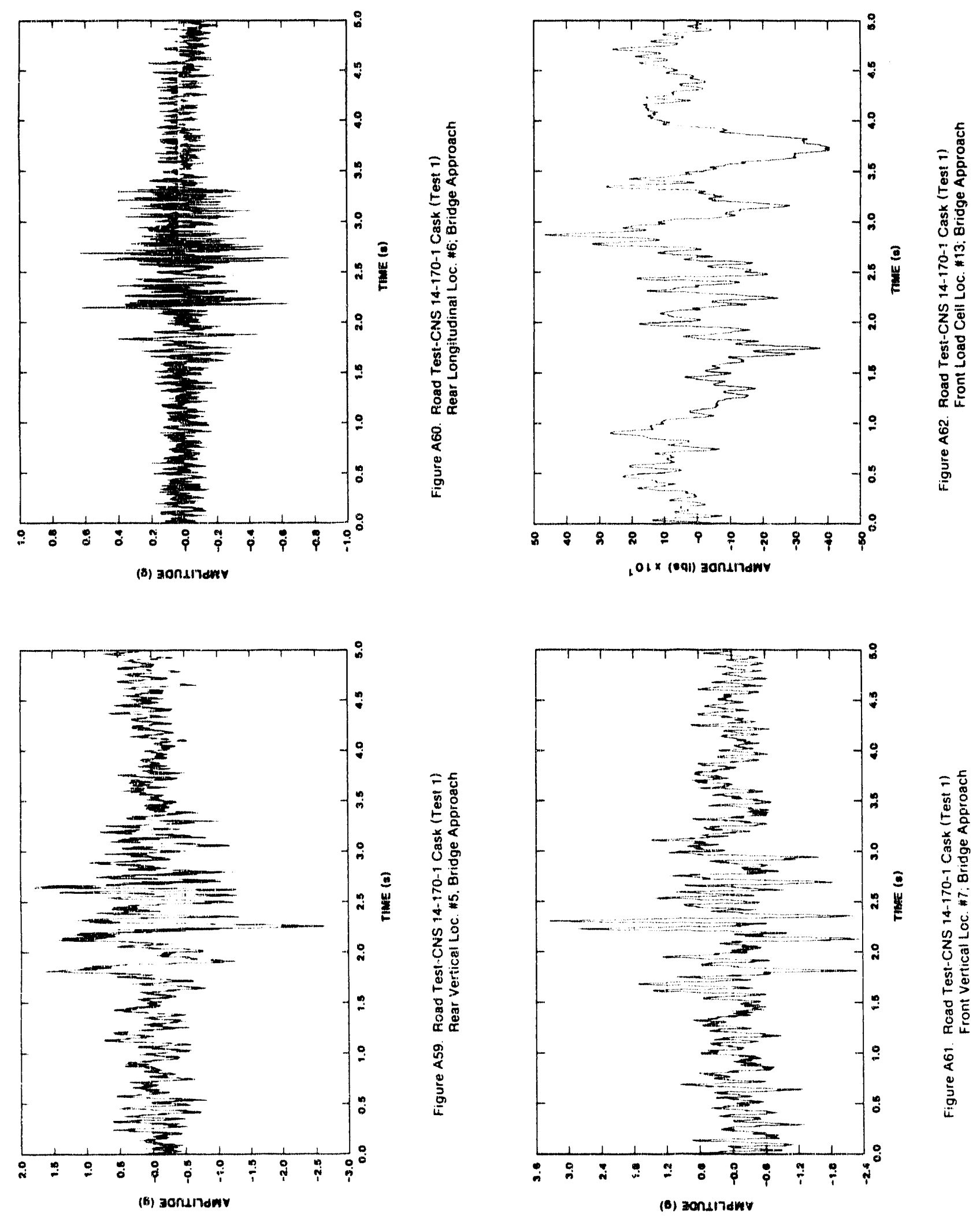


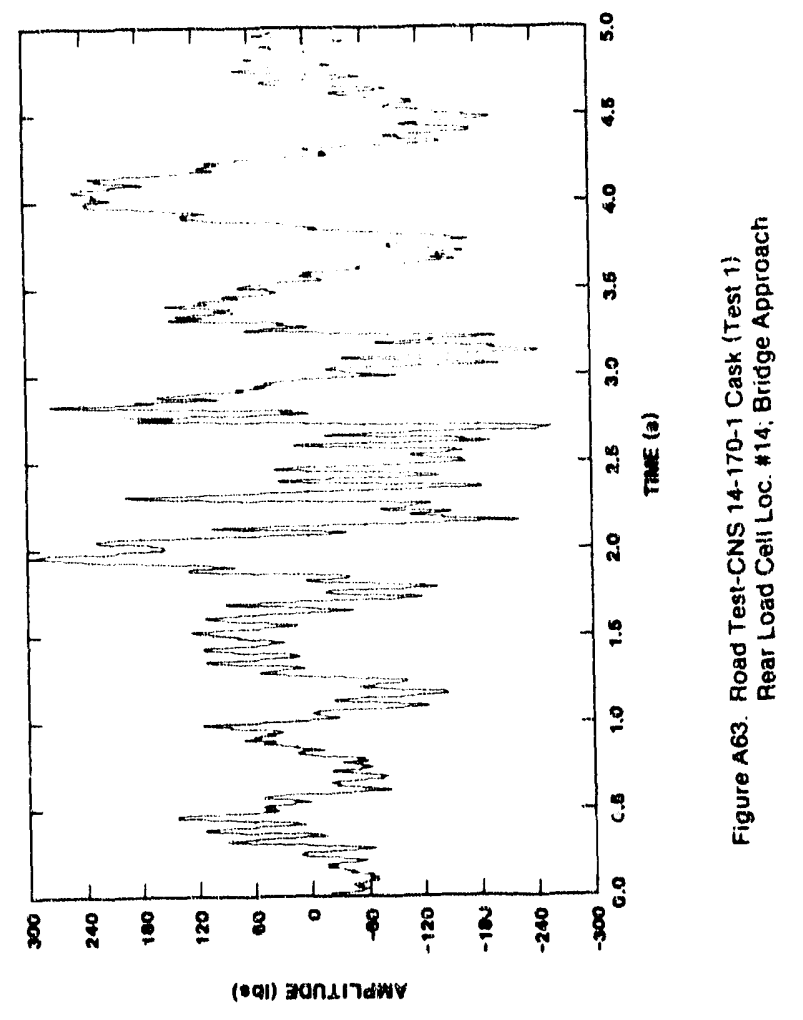




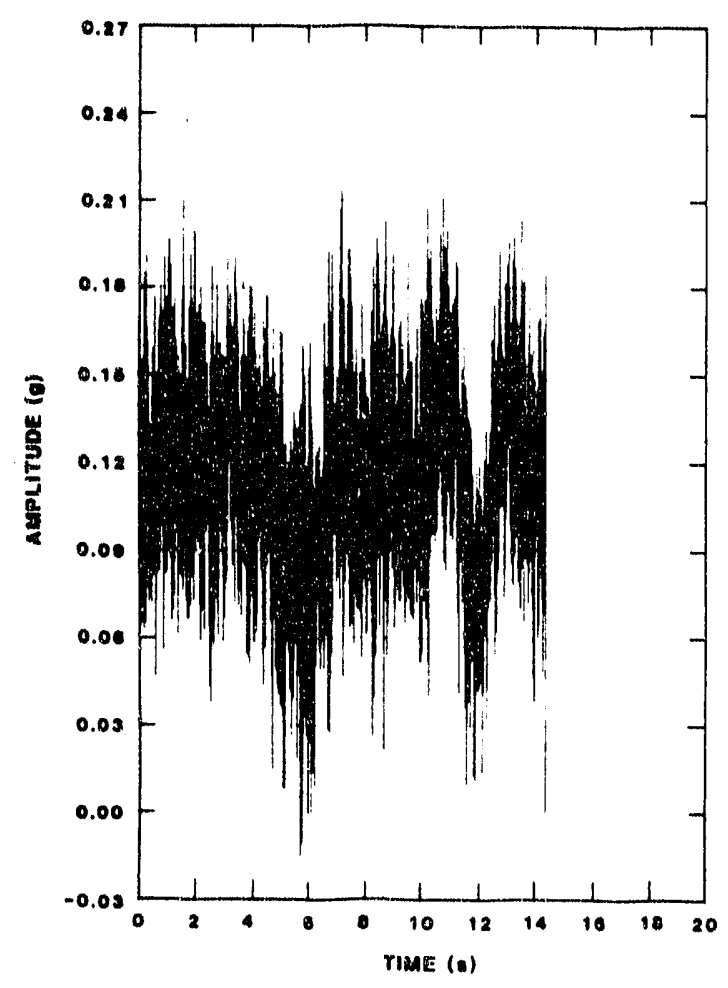

Figure A64. Road Test-CNS 14-170-1 Cask (Test 1) Top Transverse Loc. 1; Rough Concreie

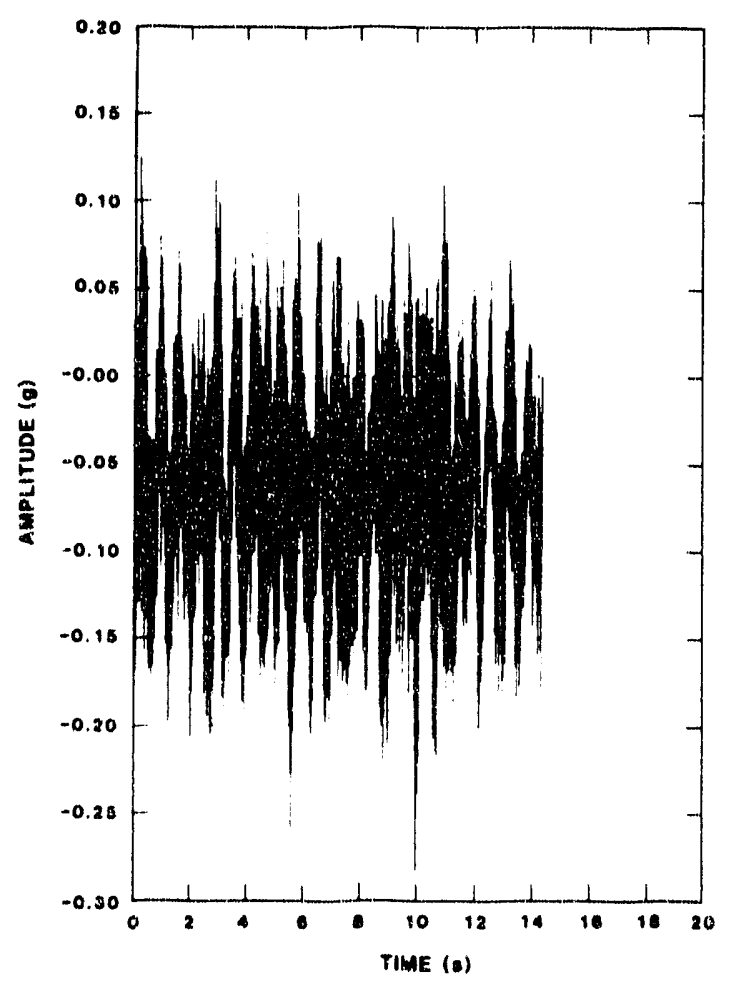

Figure A66. Hoad Test-CNS 14-170-1 Cask (Test 1) Top Vertical Loc. A2; Rough Concrete

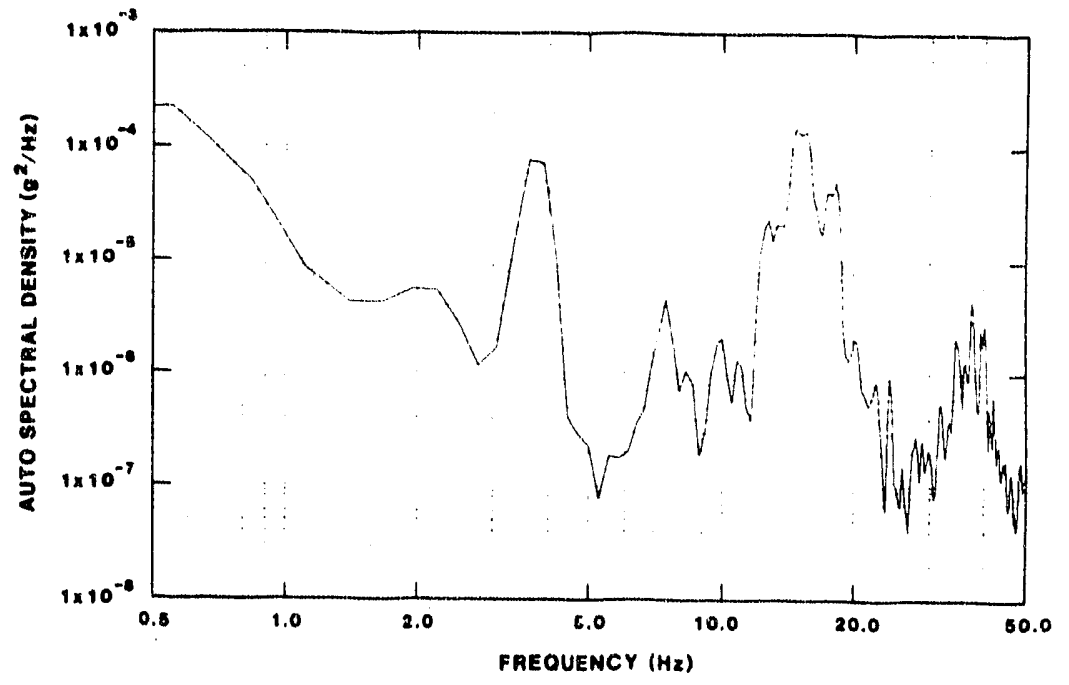

Figure A65. Road Test-CNS 14-170-1 Cask (Test 1) Top Transverse Loc. \#1; Rough Concrete

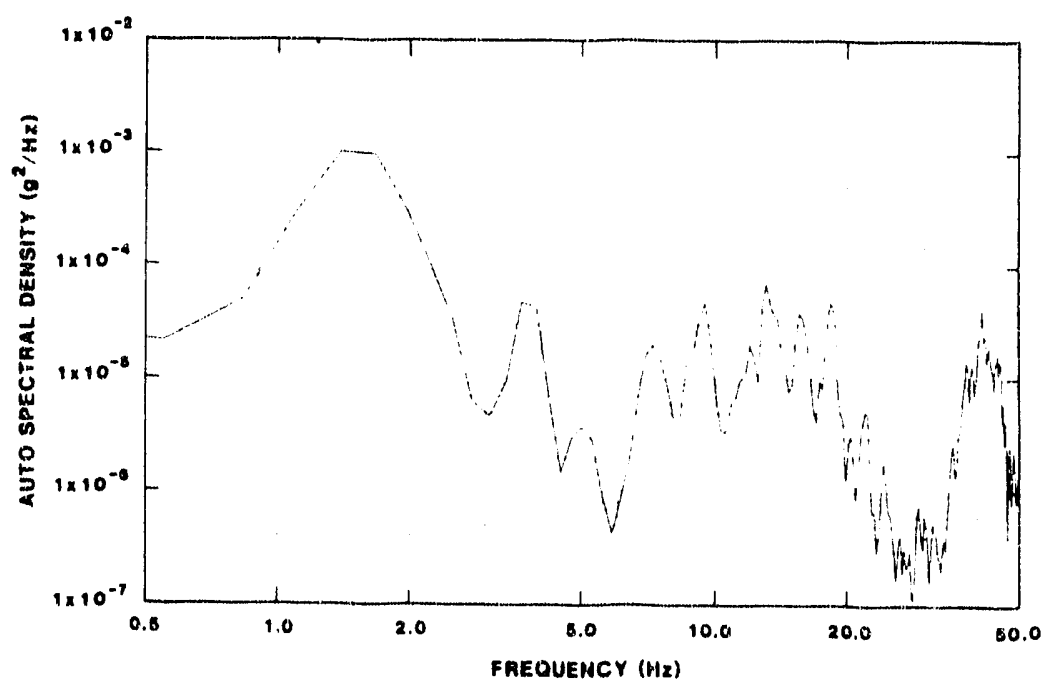

Figure A67. Road Test-CNS 14-170-1 Cask (Test 1) Top Vertical Loc. \#2; Rough Concrete 


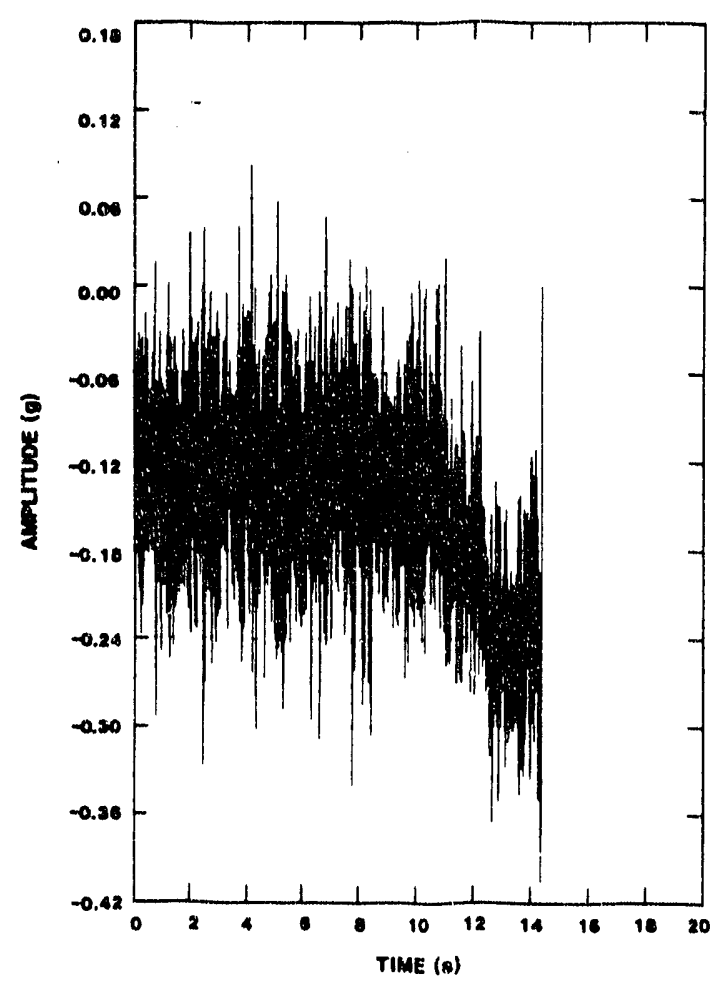

Figure A68. Road Test-CNS 14-170-1 Cask (Test 1) Top Longitudinal LOC. \#3; Fough Concrete

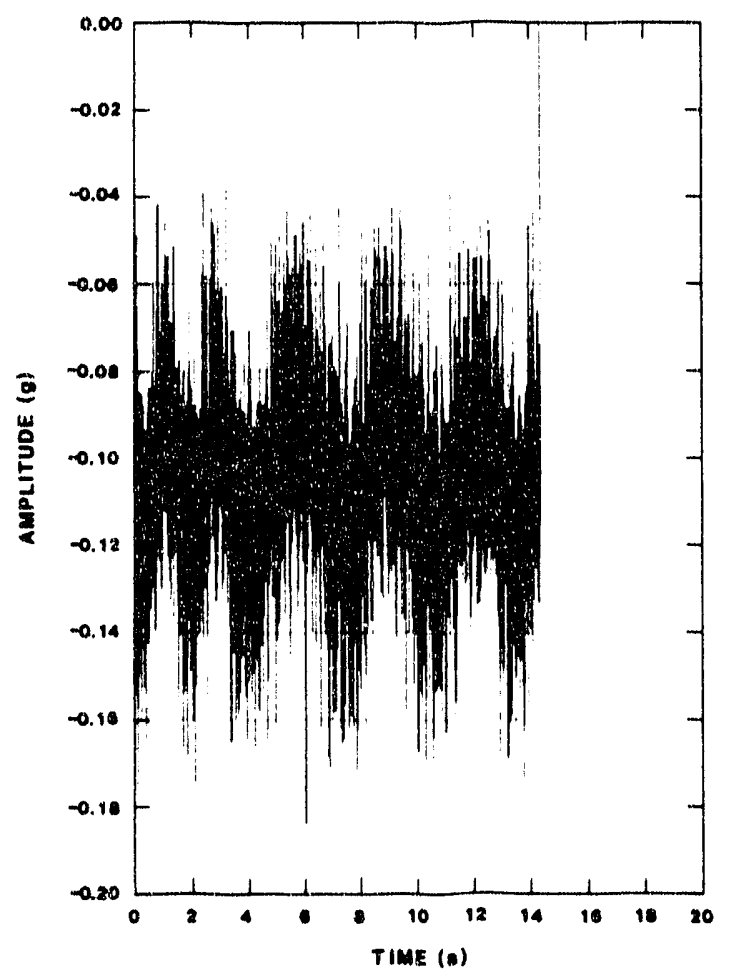

Figure A70. Road Test-CNS 14-170-1 Cask (Test 1) Mid Vertical LOC. *4; Rough Concrete

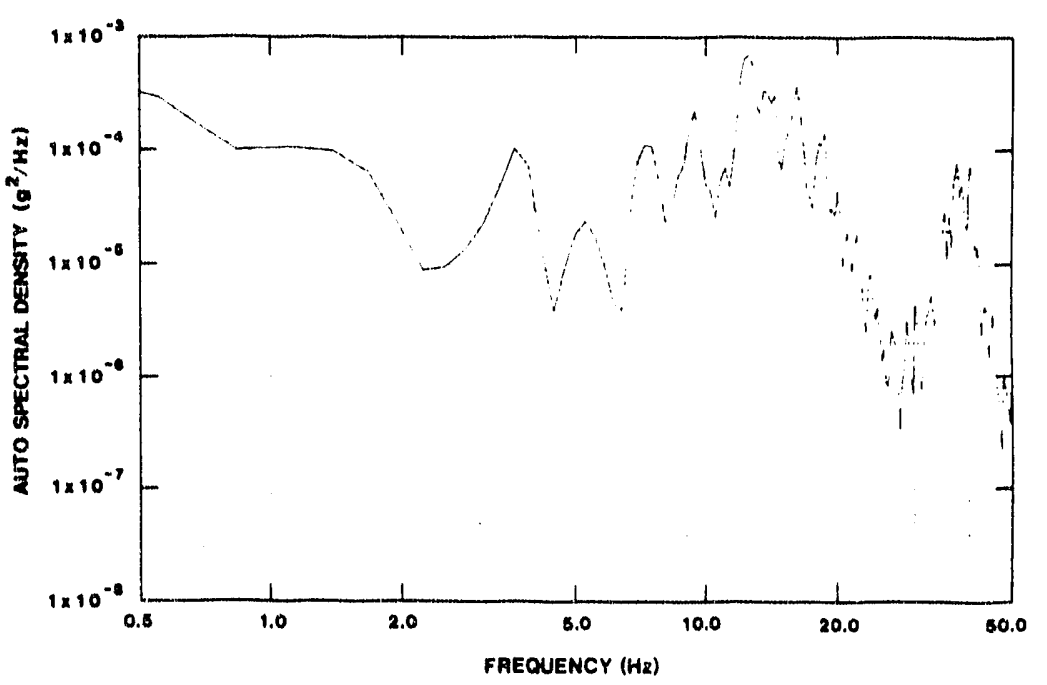

Figure A69. Road Test-CNS 14-170-1 Cask (Test 1) Top Longitudinal Loc. \#3; Rough Concrete

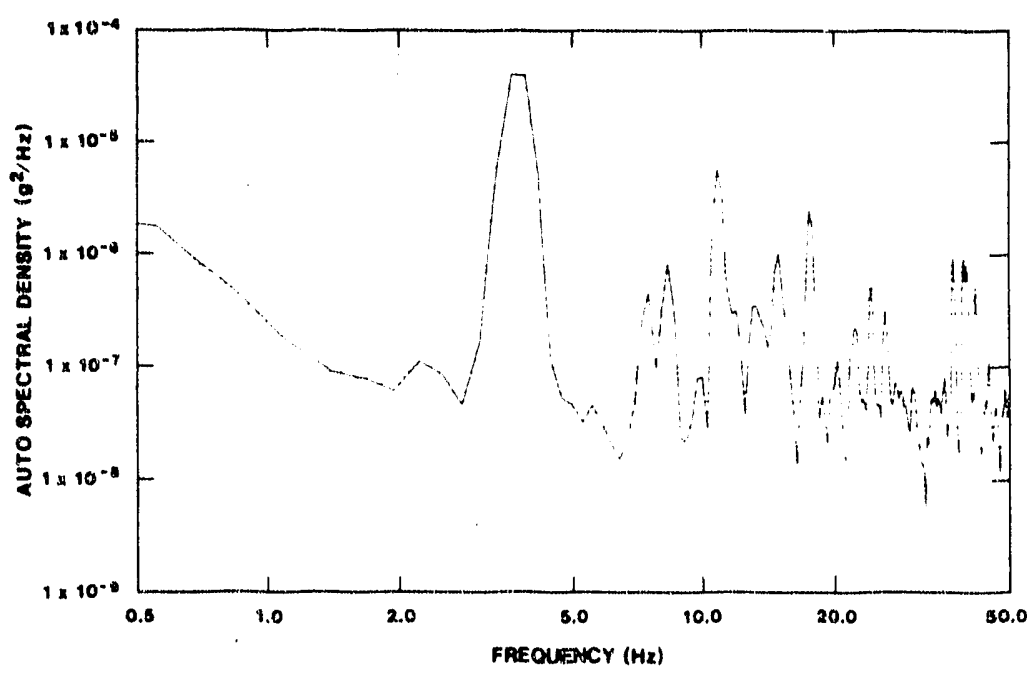

Figure A71. Road Test-CNS 14-170-1 Cask (Test 1) Mid Vertical Loc. 44: Rough Concrete 


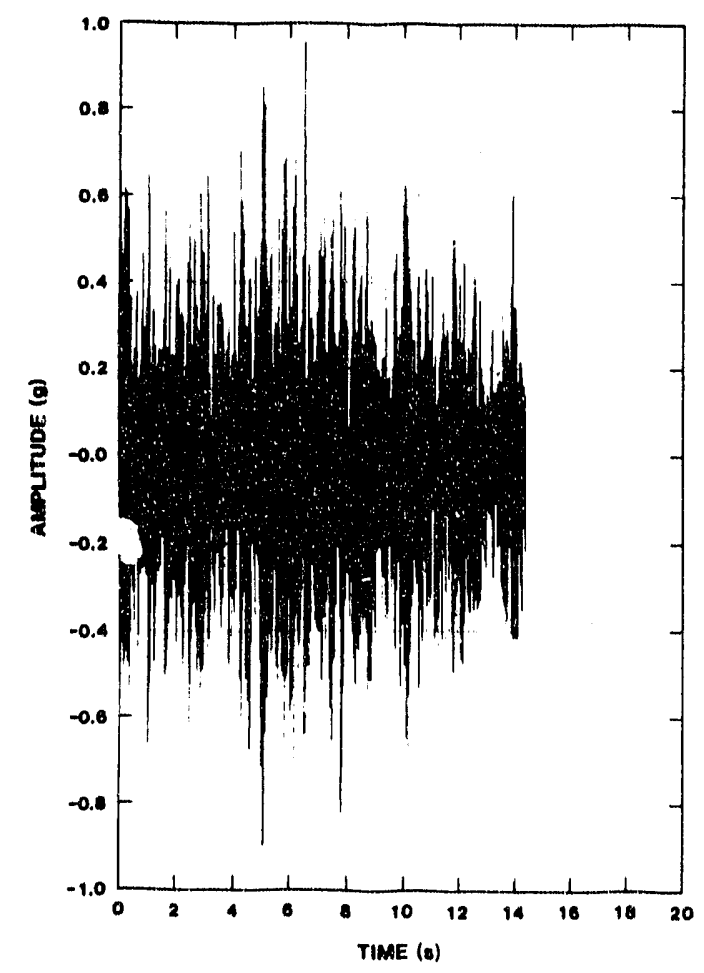

Figure A72. Road Test-CNS 14-170-1 Cask (Test 1) Rear Vertical Loc. \#5; Rough Concrete

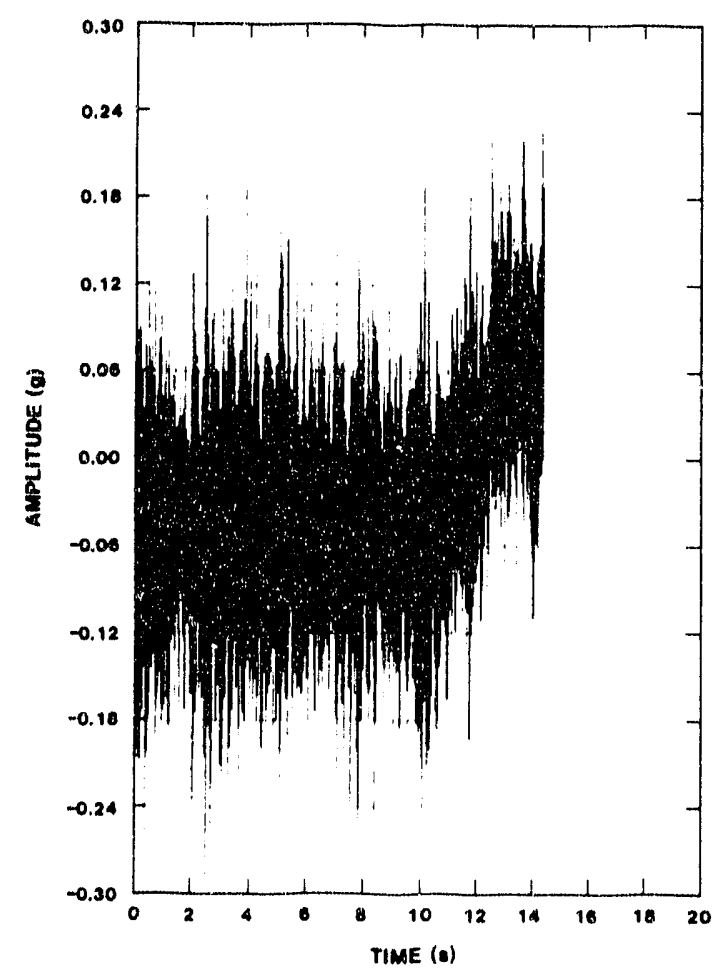

Figure A74. Road Test-CNS 14-170-1 Cask (Test 1) Rear Longitudinal LoC \#6; Rough Concrete

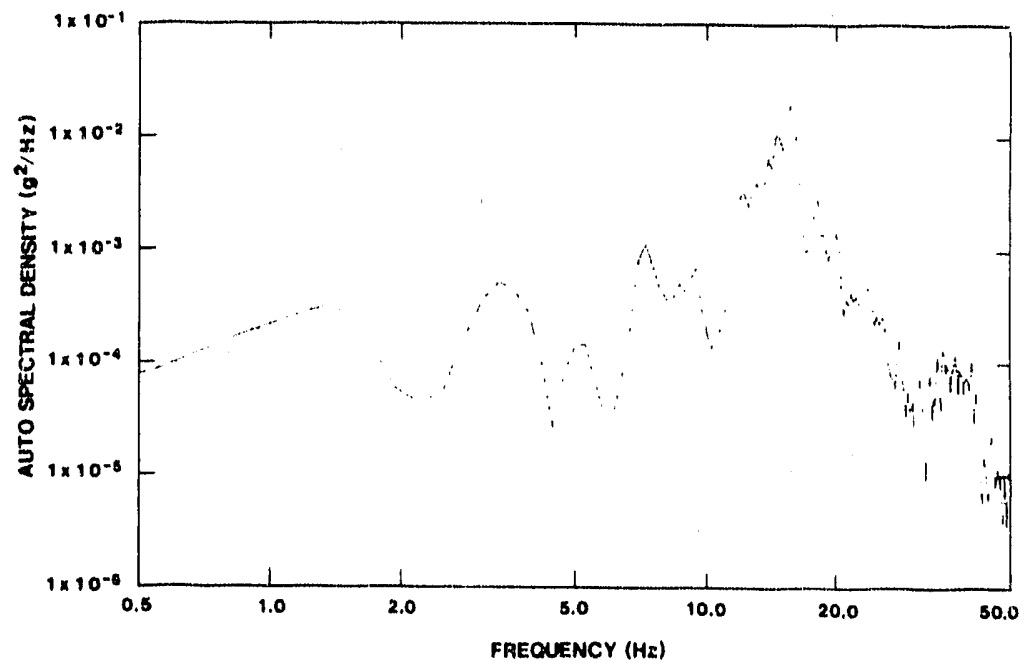

Figure A73. Road Test-CNS 14-170-1 Cask (Test 1) Rear Vertical Loc. \#5; Rough Concrete

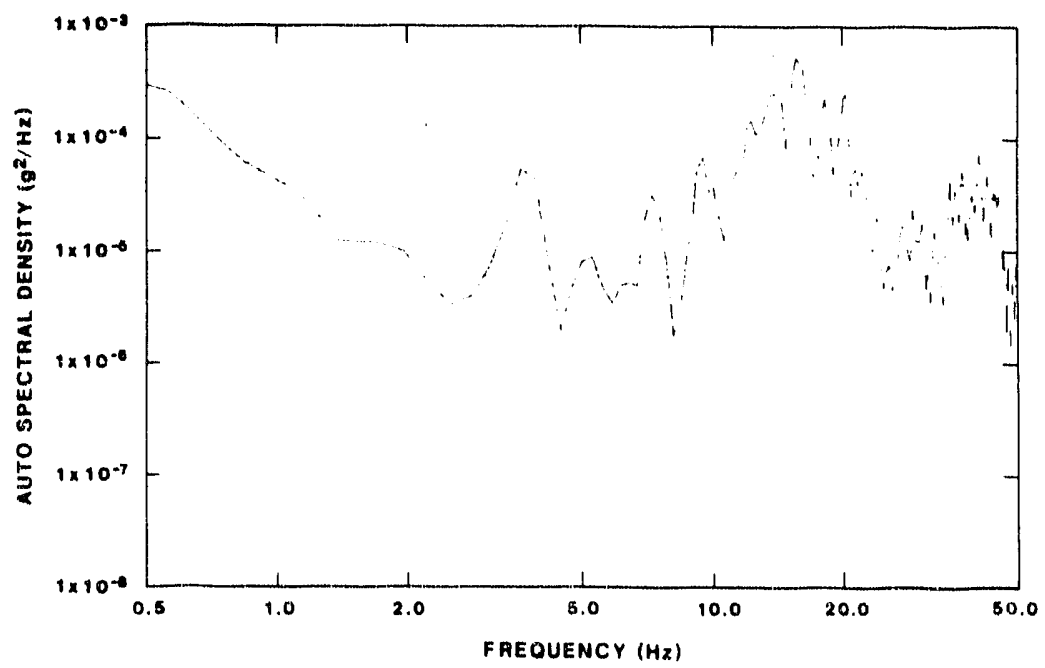

Figure A75. Road Test-CNS 1A-170-1 Cask (Test 1) Rear Longitudinal Loc. 6 ; Rough Concrete 


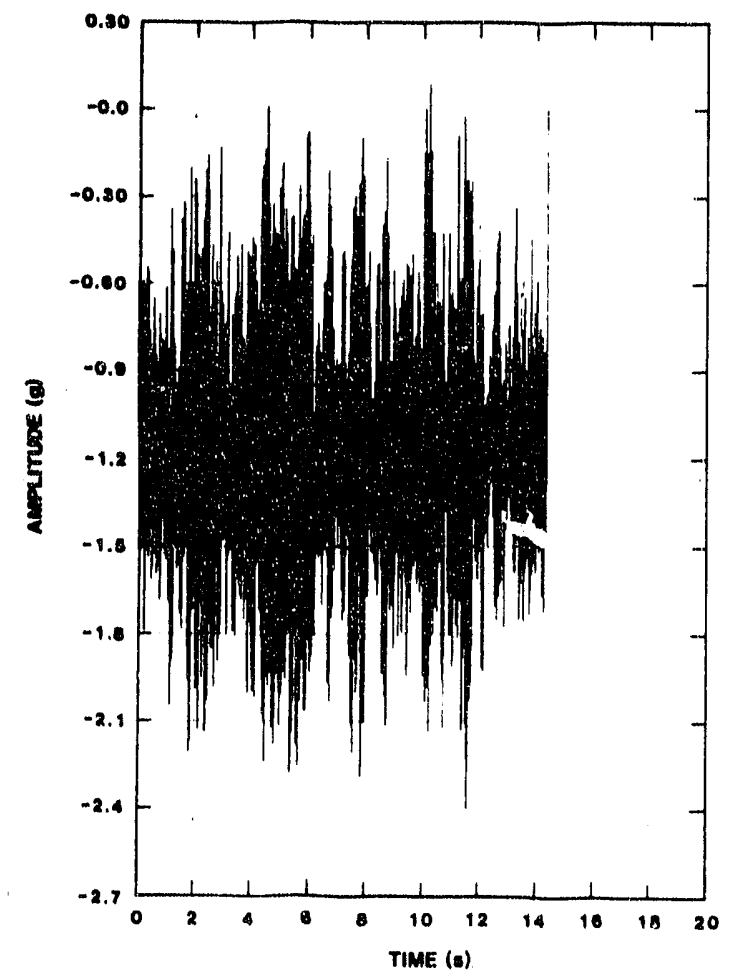

Figure A76. Foad Test-CNS 14-170-1 Cask (Test 1) Front Vertical LoC \#7; Rough Concrete

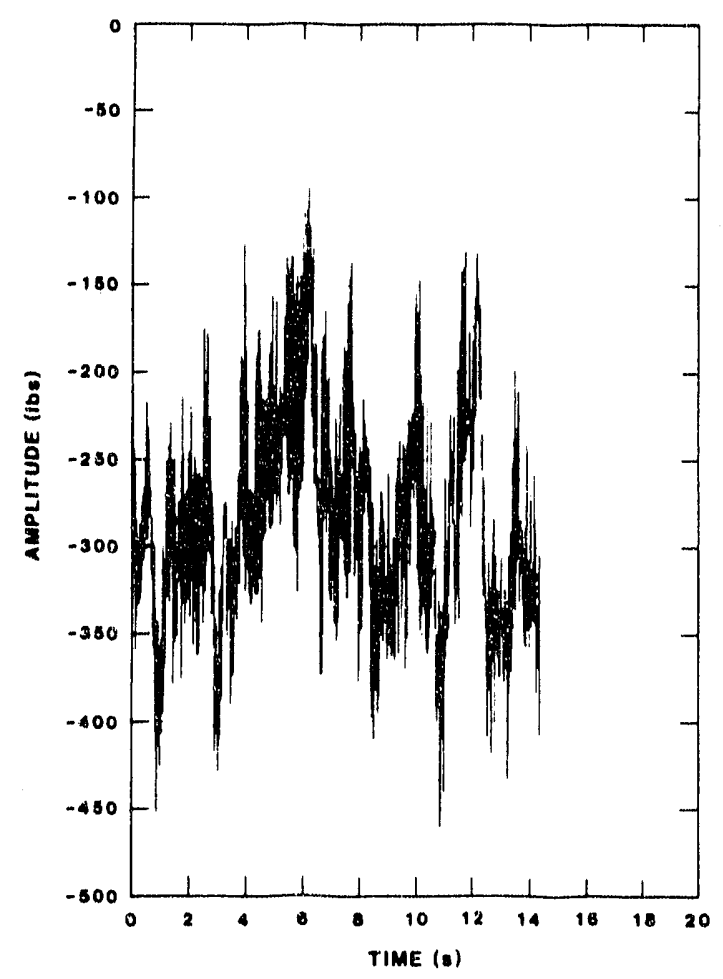

Figure A78. Hoad Test-CNS 14-170-1 Cask (Test 1) Front Load Cell Loc. \#13; Rough Concrete

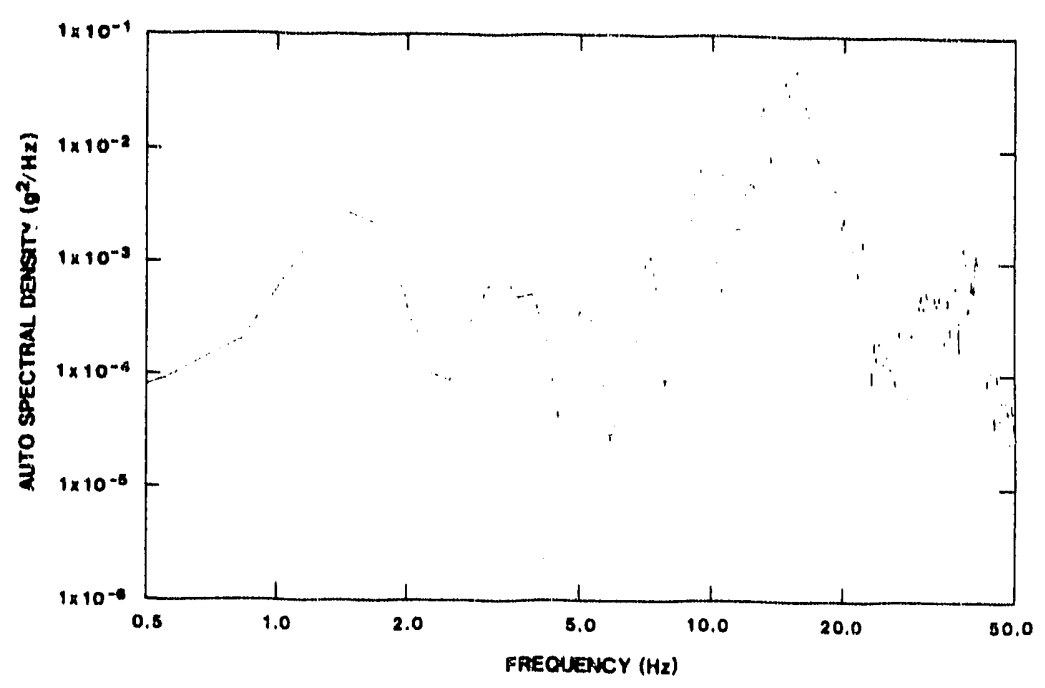

Figure A77. Road Test-CNS 14-170-1 Cask (Test 1) Front Vertical Loc. 47 ; Rough Concrete

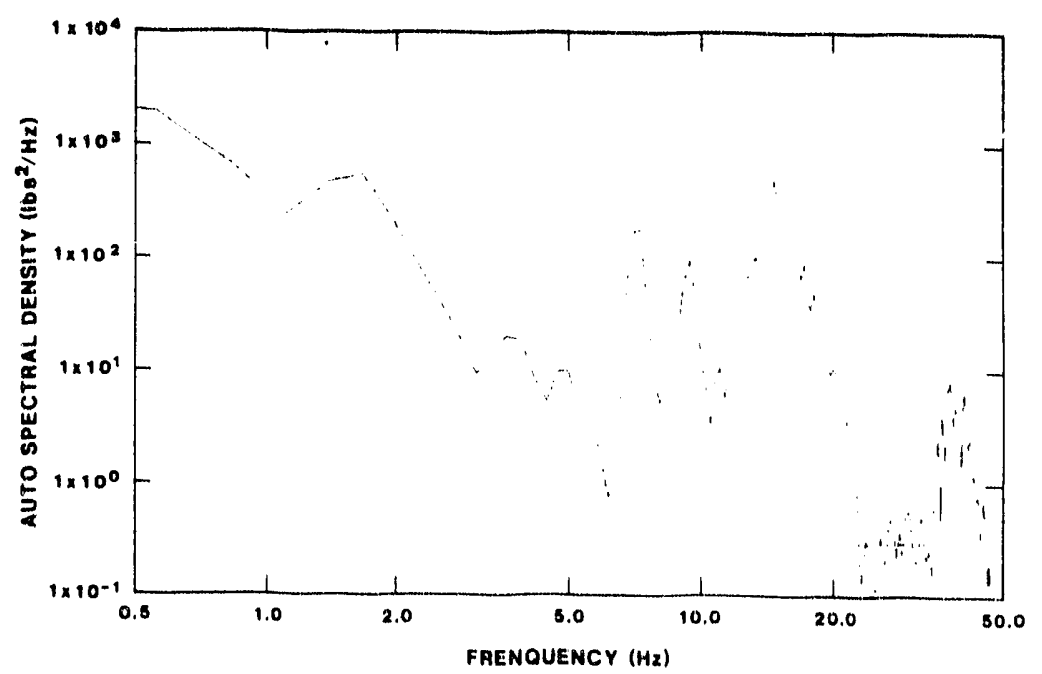

Figure A79. Foad Test-CNS 14-170-1 Cask (Test 1) Front Load Cell LoC. 13; Rough Concrete 


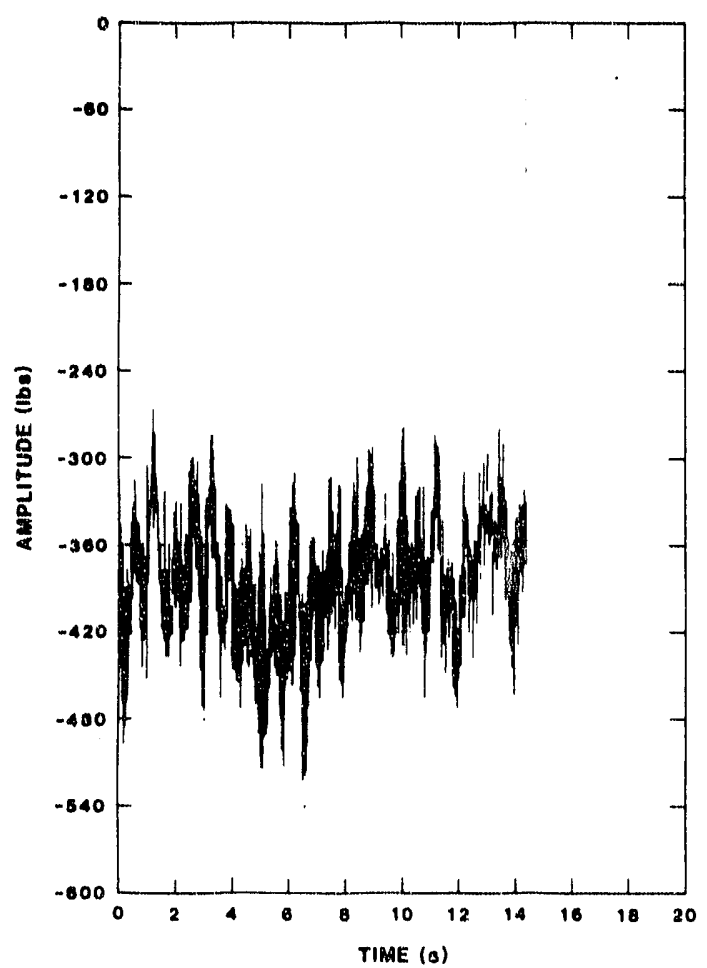

Figure A80. Road Test-CNS 14-170-1 Cask (Test 1) Rear Load Cell Loc. \#14; Rough Concrete

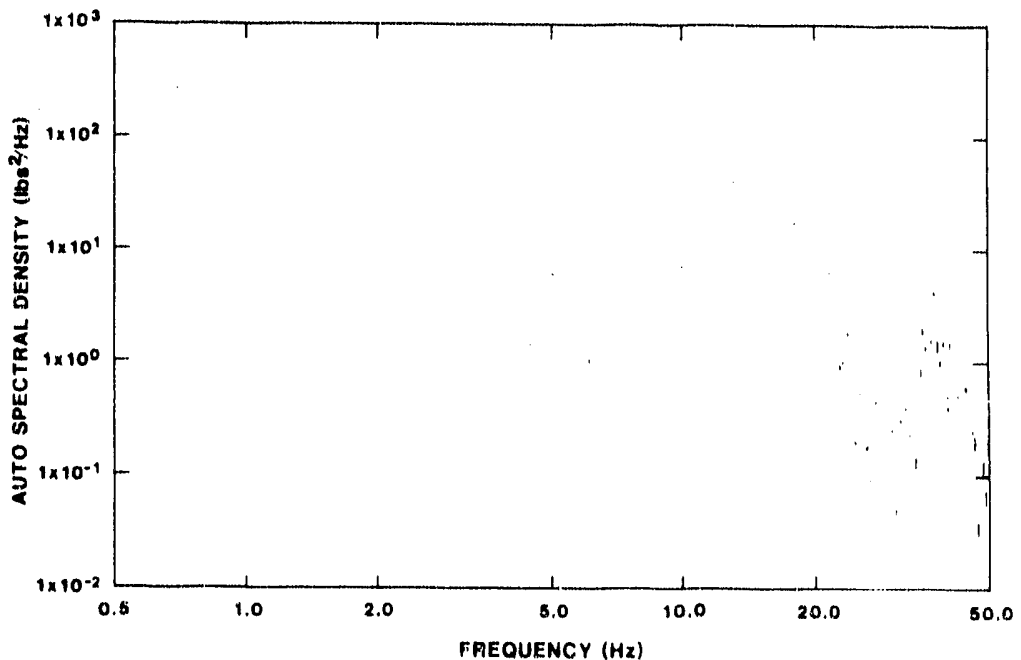

Figure A81. Road Test-CNS 14-170-1 Cask (Test 1) Rear Load Cell Loc. \#14; Rough Concrete 


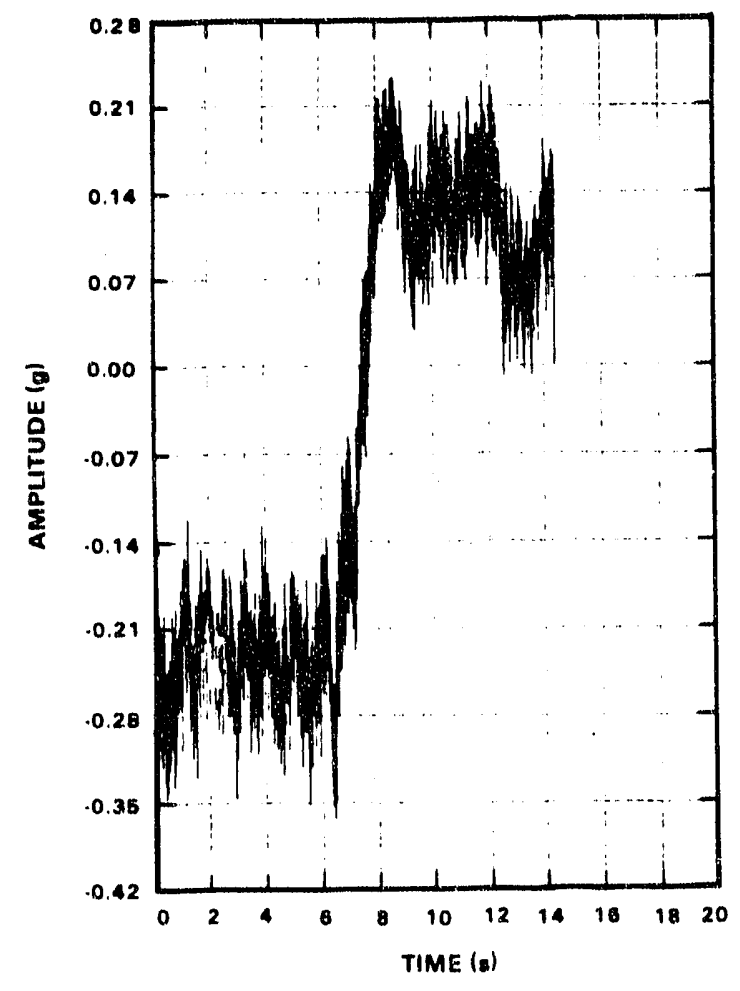

Figure A82. Road Test-CNS 14-170-1 Cask (Test 1) Top Transverse Loc. $\$ 1$; Hard Aight Turn

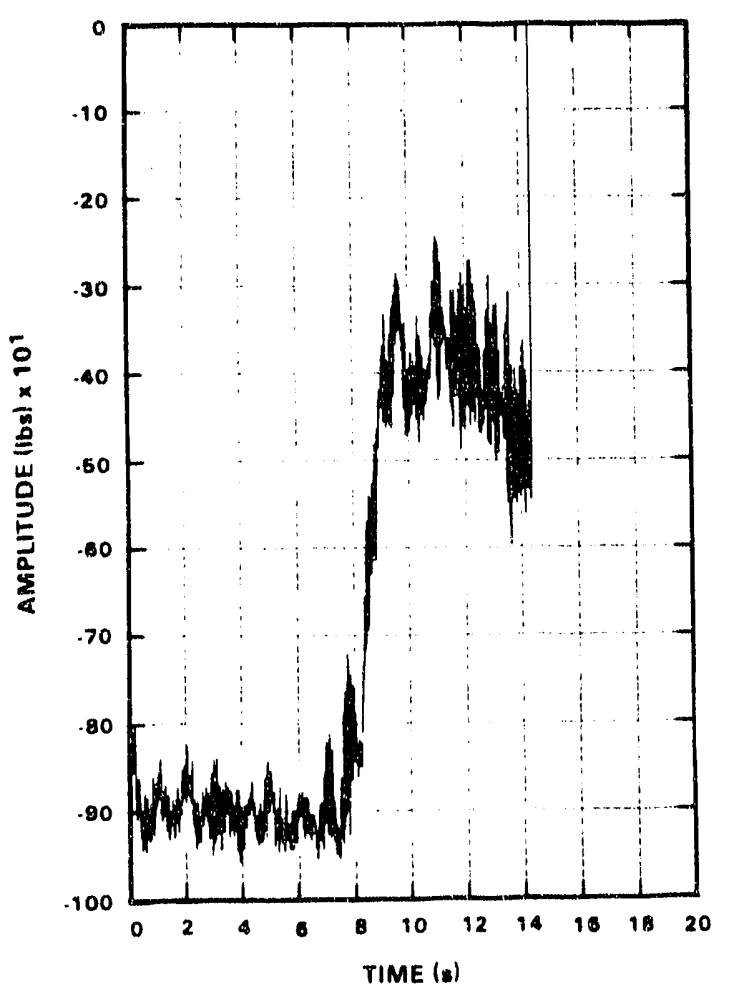

Figure A84. Road Test-CNS 14.170-1 Cask (Test 1)

Hear Load Cell Loc. \#14; Hard Right Turn

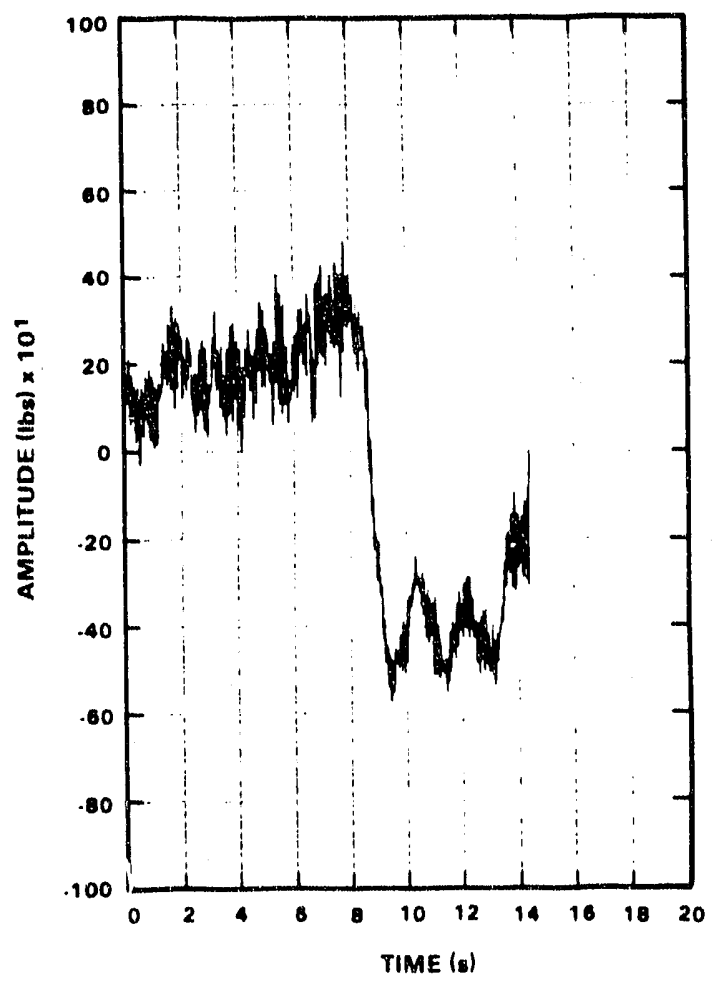

Figure A83. Road Test-CNS 14.170-1 Cask (Test 1 ) Front Load Cell Loc. \#13; Hard Right Turn 


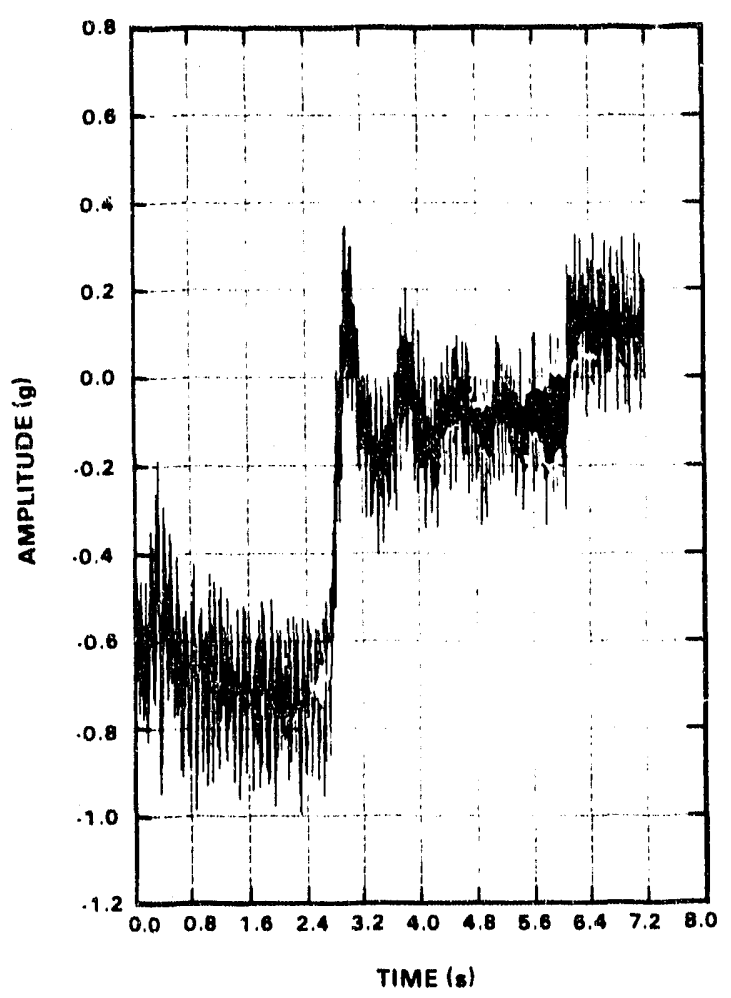

Figure A85. Road Test-CNS 14-170-1 Cask (Test 1 ) Top Longitudinal Loc. $\# 3$; Hard Stop $\sharp 8$

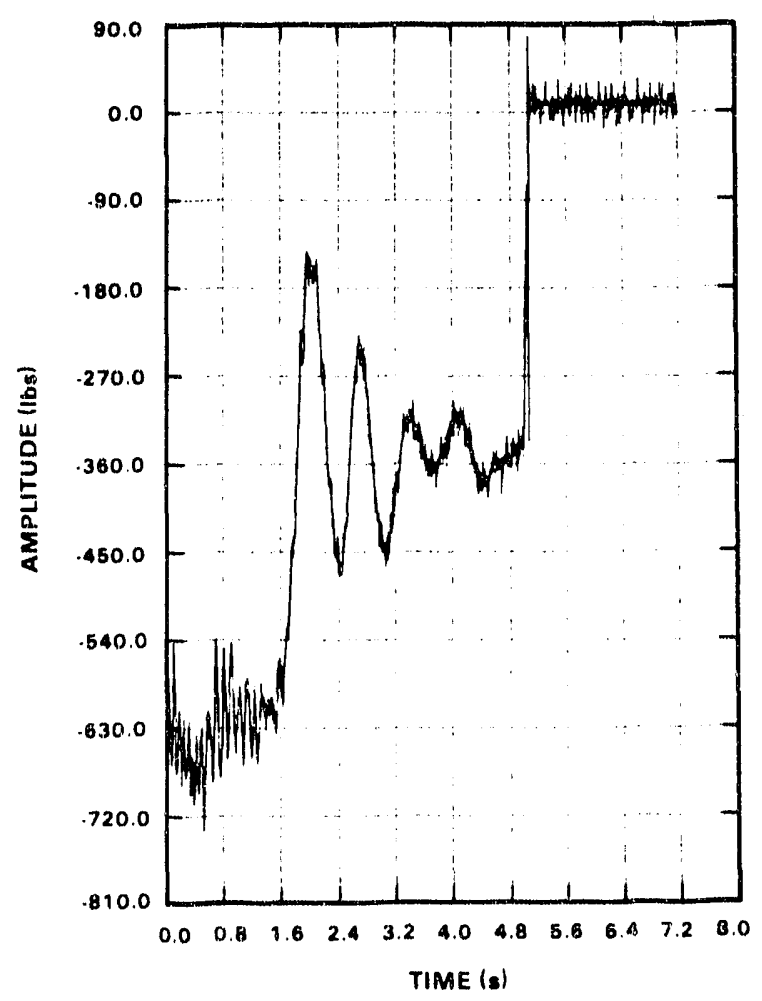

Figure A87. Road Test-CNS 14-170.9 Cask (Test 1) Front Load Ce Loc. $\$ 1$ 3; Hard Stop $\$ 8$

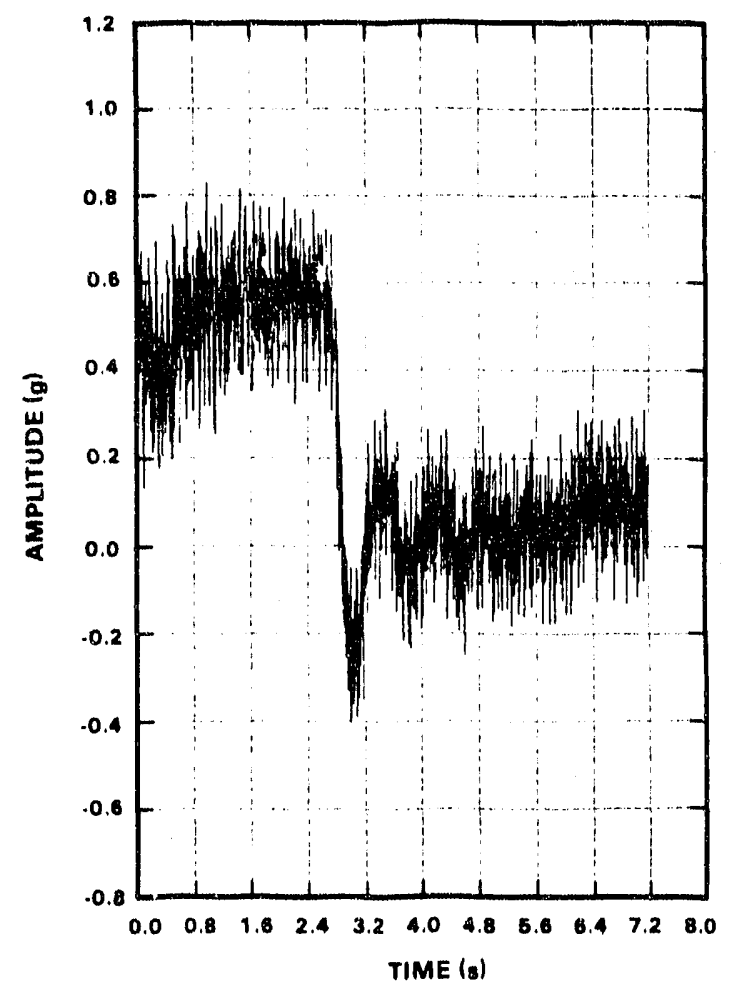

Figure A86. Road Test-CNS 14-170-1 Cask (Test 1) Rear Longitudinal Loc. \#6; Hard Stop $\# 8$

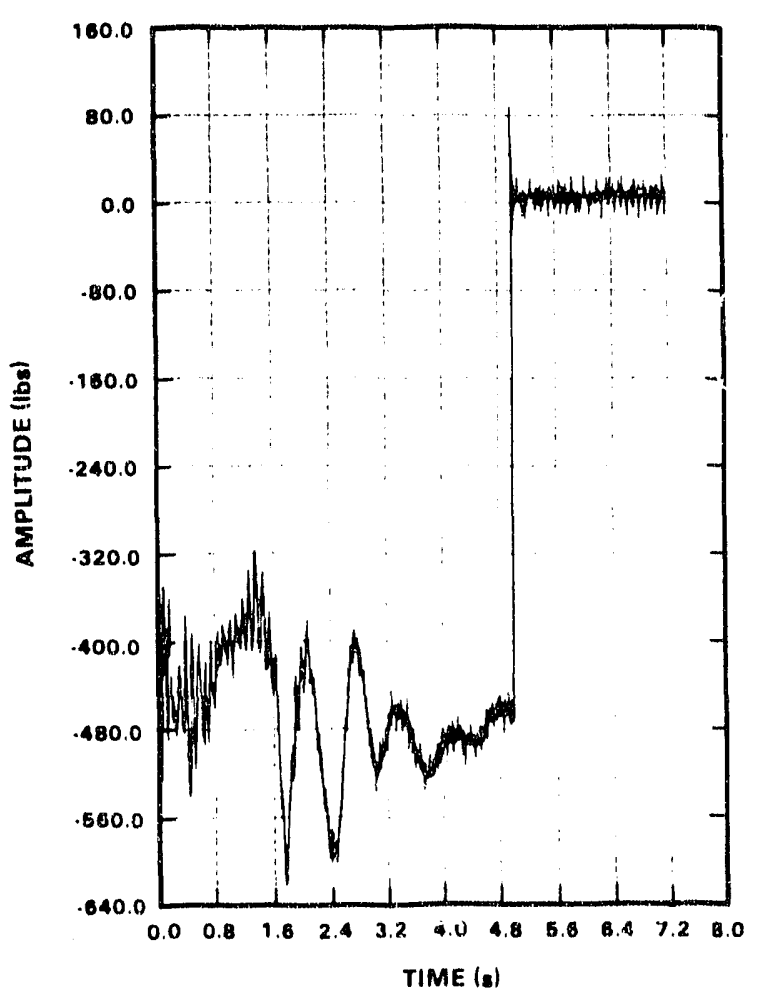

Figure A88. Road Test.CNS 14.170-1 Cask (Test 1) Rear Load Cell Loc. \#14; Hard Stop $\# 8$ 


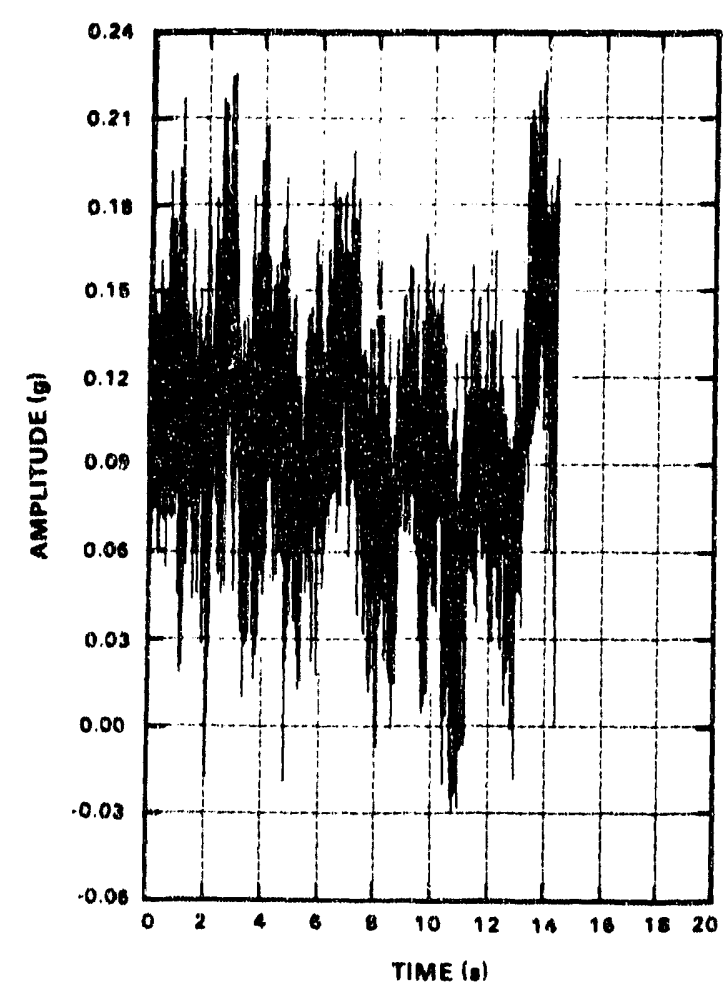

Figure A89. Aoad Test-CNS 14.170., Cask (Test 1) Top Transwerse Loc. 1: Rough Secondary

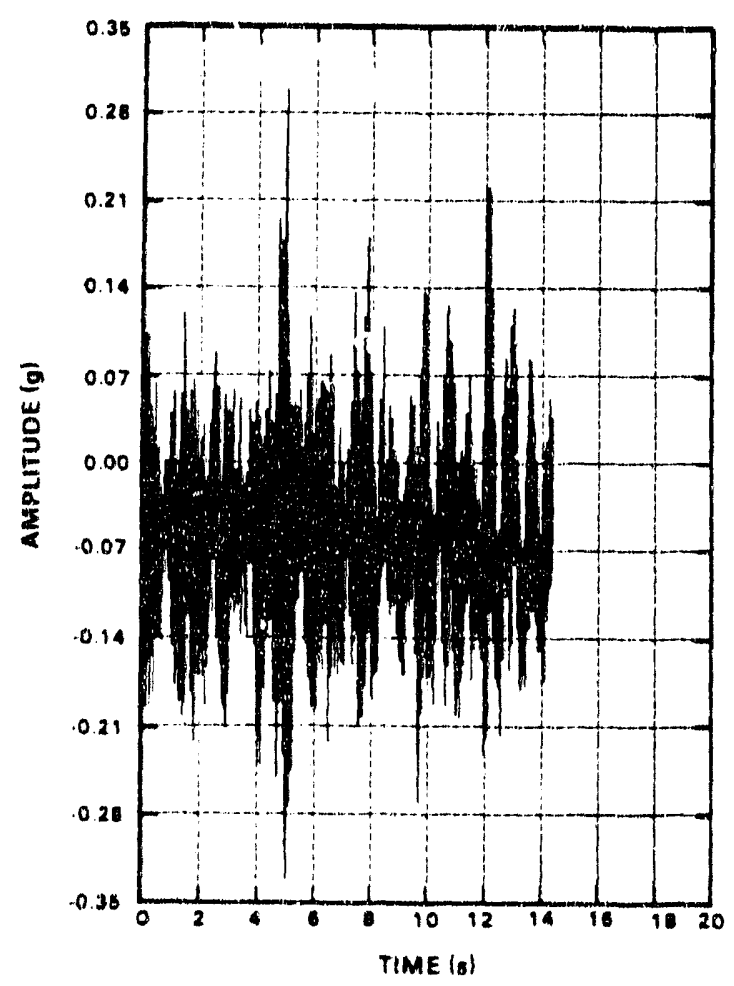

Figure A91. Road Test.CNS 14.170 .1 Cosk (Test 1) Top Vertical Loc. H2. Rough Secondary

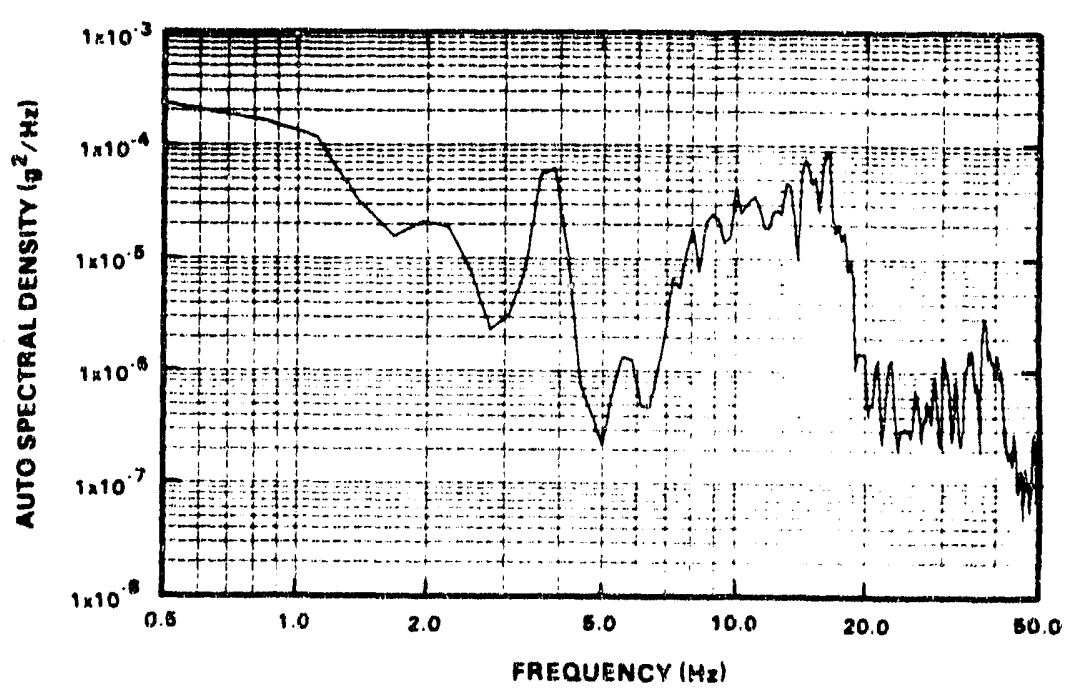

Figure A90. Ruad Test-CNS 14.170.1 Cask (Test 1) Top Transverse Loc. H1: Rough Secondary

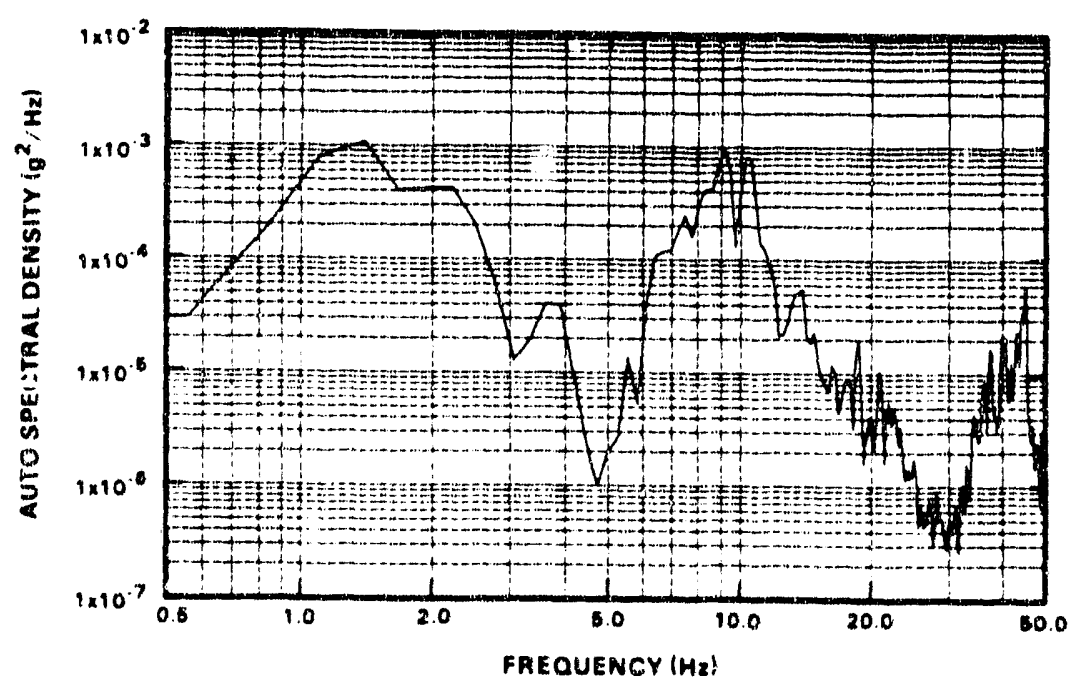

Figure A92. Road Test-CNS 14.170 .1 Gask (Teat II Top Vertical Loc H2, Rough Secondery 


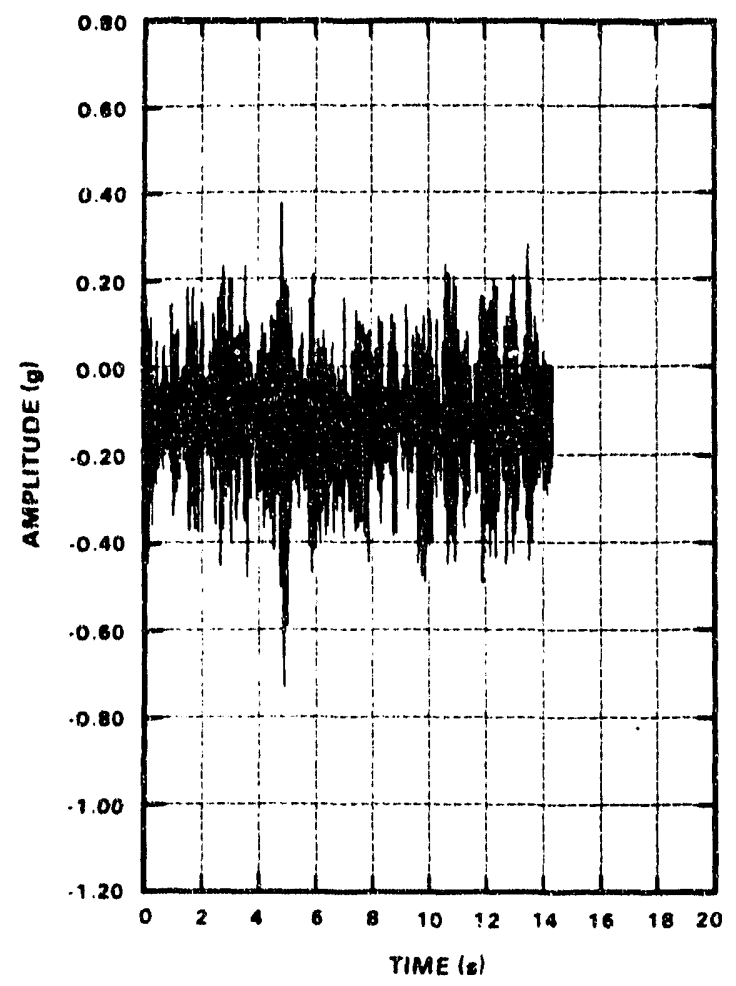

Figure A93. Ruad Test-CNS 14-170.1 Cask (Test 1 ) Top Longitudinal Loc. \#3; Rough Secondary

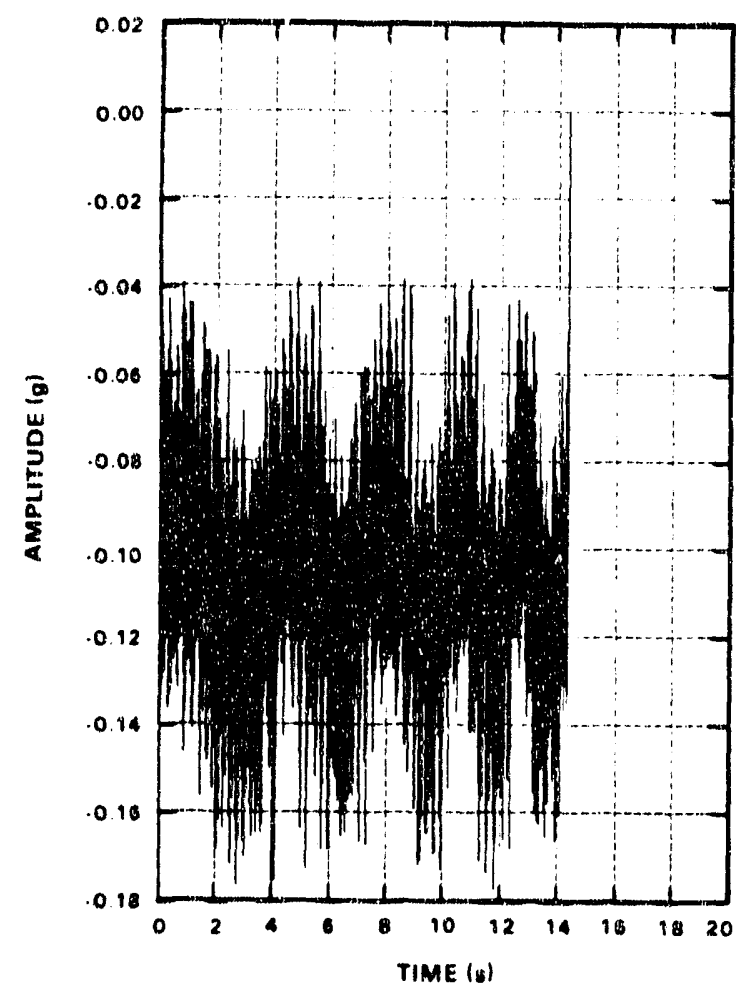

Figure A95. Road Test.CNS 14-170.1 Cask (TEst 1) Mio Verrical Loc. \#4. Rough Stannder;

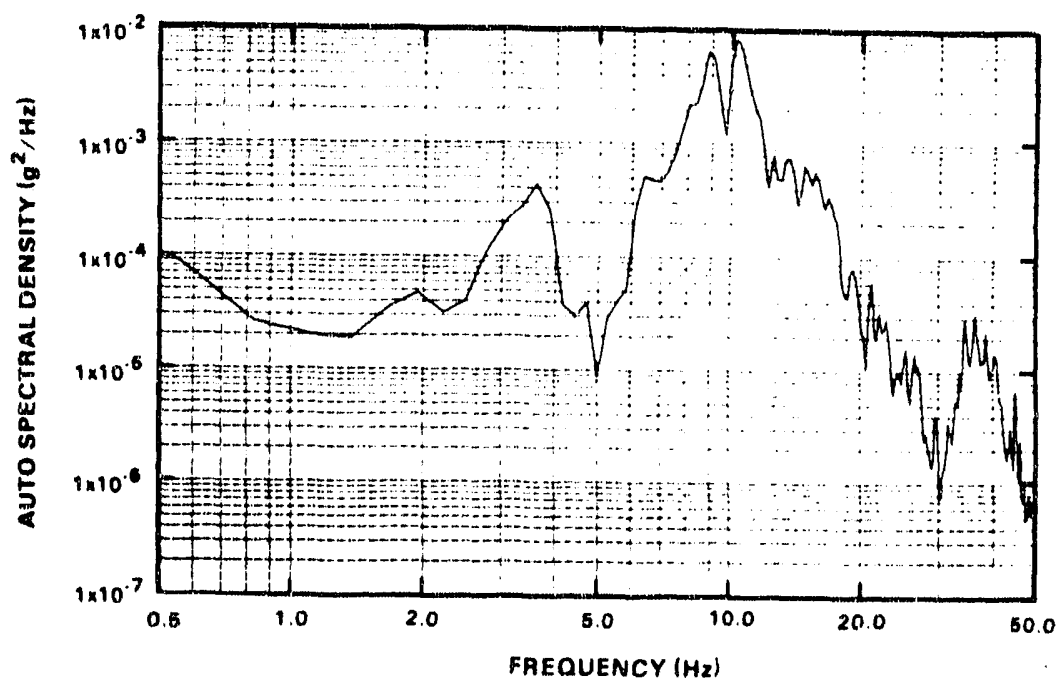

Figure A94. Road Test-CNS 14.170.1 Cask (Test 1 ) Top Longitudinal Loc. \#3: Rough Secondary

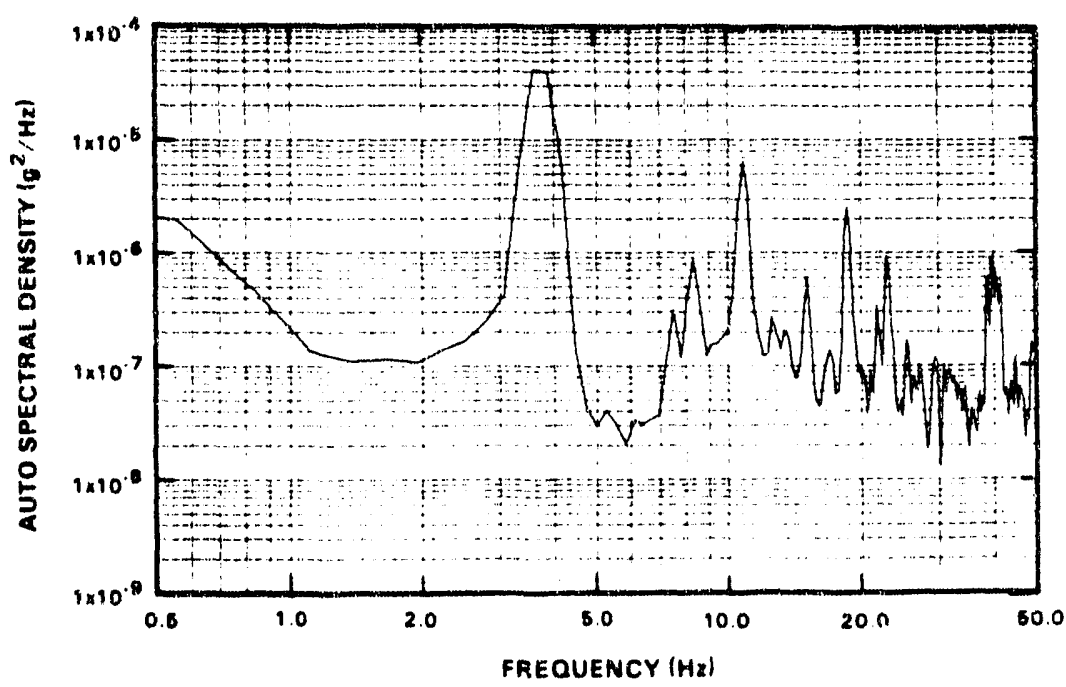

Figuro A96. Road Test.CNS 14.170.1 Cask (Test i) Mid Vertical Loc \#4; Rough Secondary 


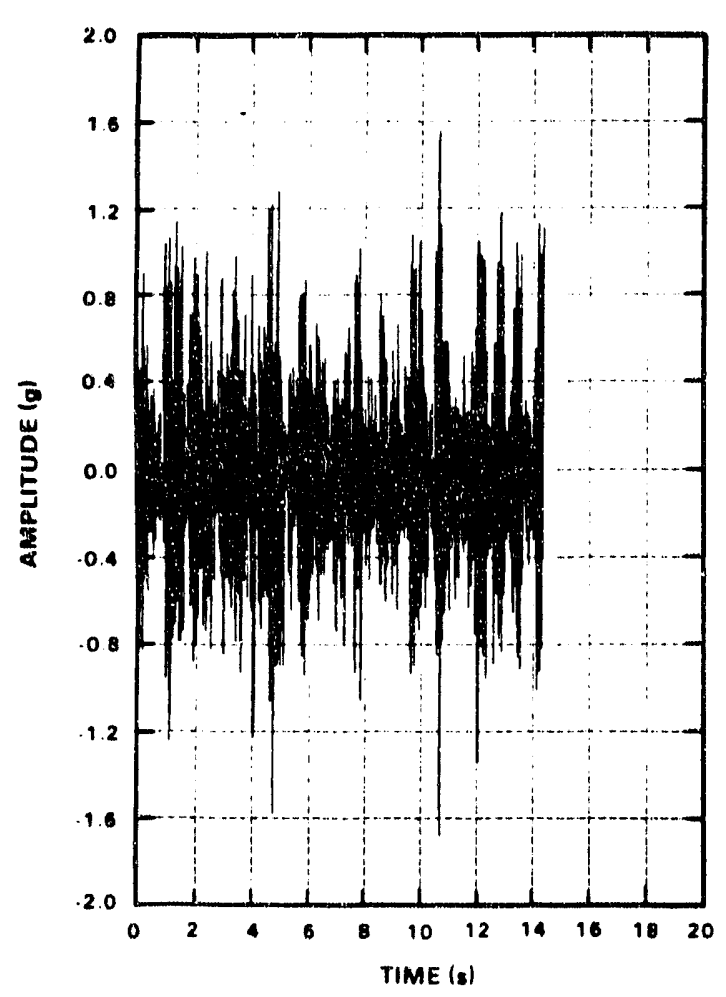

Figure A97. Road Test-CNS 14.170.1 Cask (rest 1 ) Rear Vertical Loc. \#5; Fough Secondary

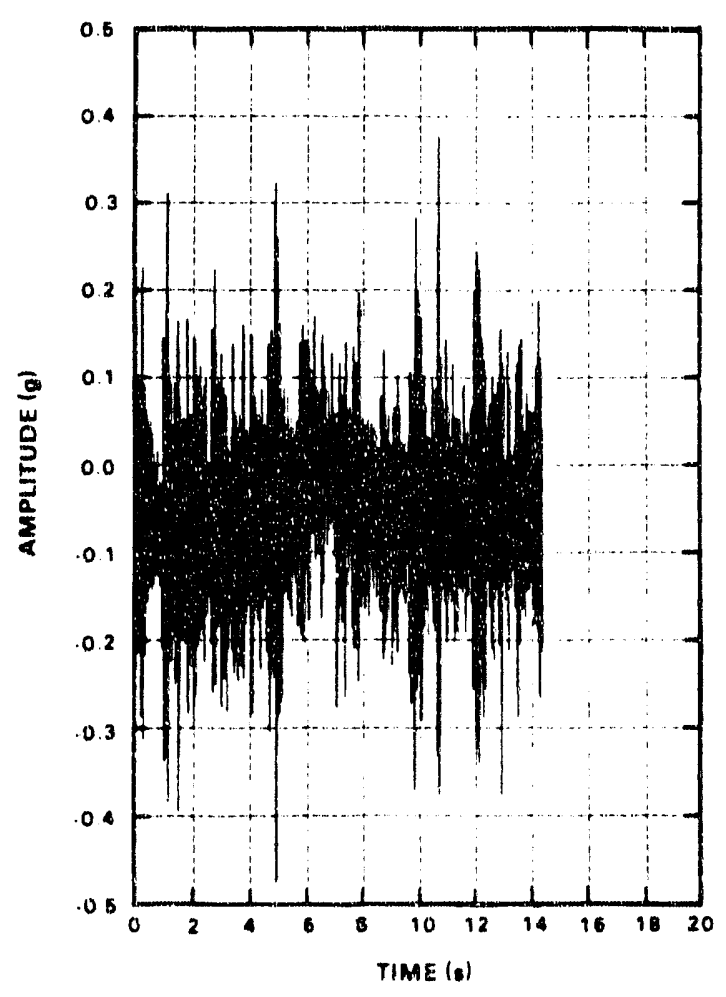

Figure A99. Road Test.CNS 14.170 .1 Cask (Test 1 ) Rear Longitudinal Loc. $\# 6$. Rough Secondary

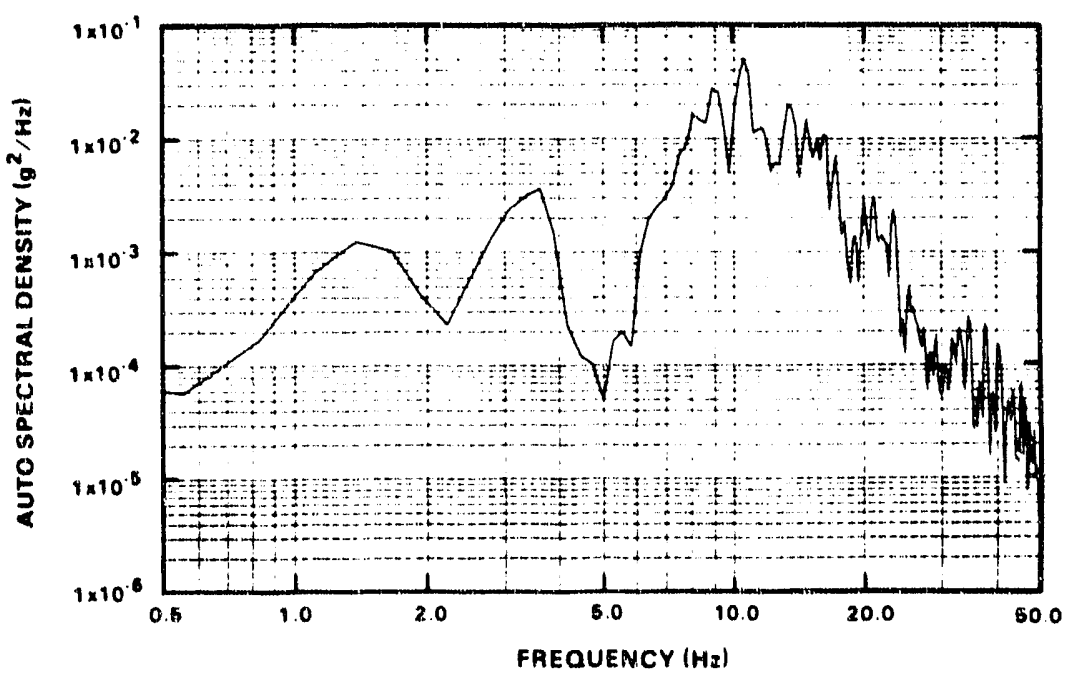

Figure A98. Road Test-CNS 14.170.1 Cask (Test 1) Rear Vertical Loc. H5; Rough Secondary

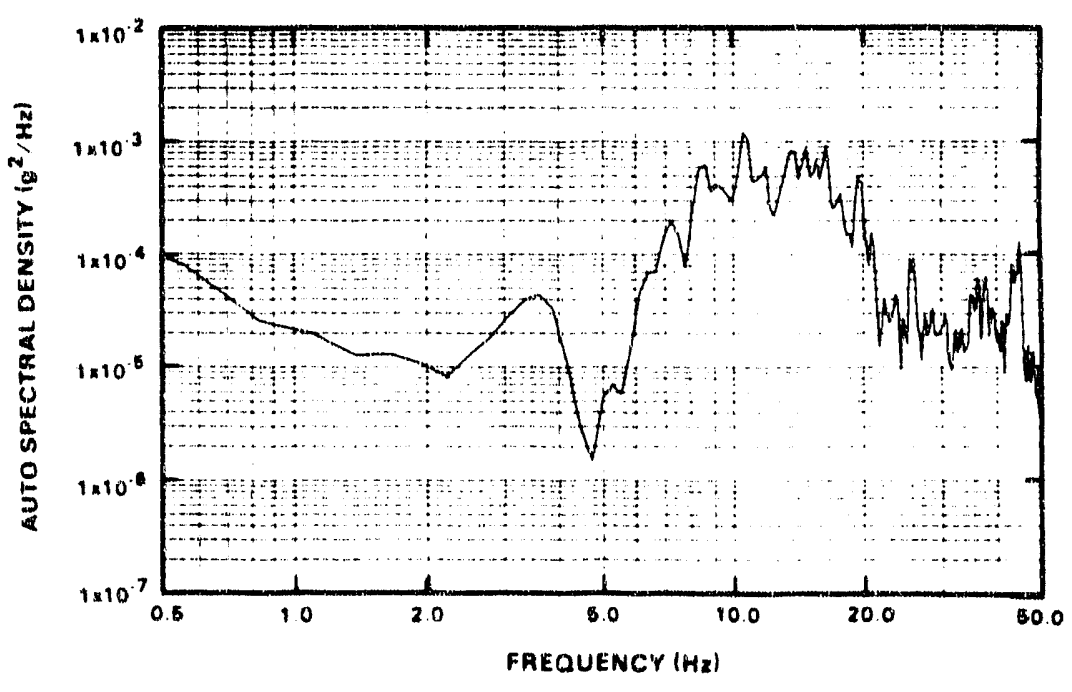

Figure A100. Road Test.CNS 14.170.1 Cask ITest 11 Rear Longltudinal Loc. \#6. Hough Secondary 


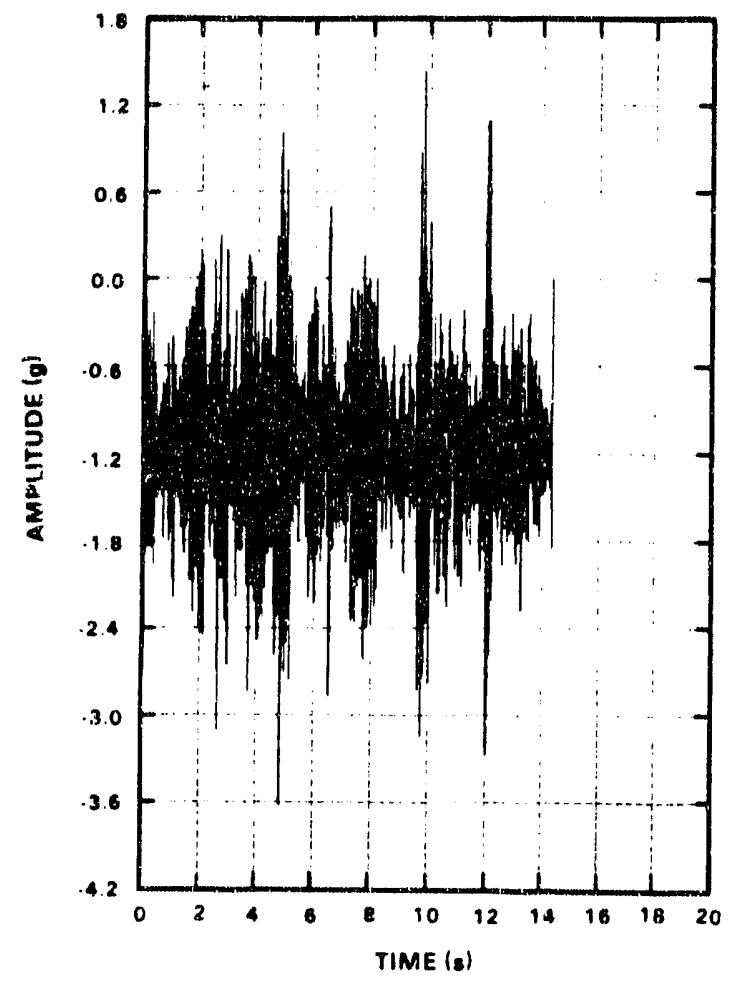

Figure A101. Road Test.CNS 14-170.1 Cask (Test 1) Front Vertica! Loc. \#7; Rough Secoridary

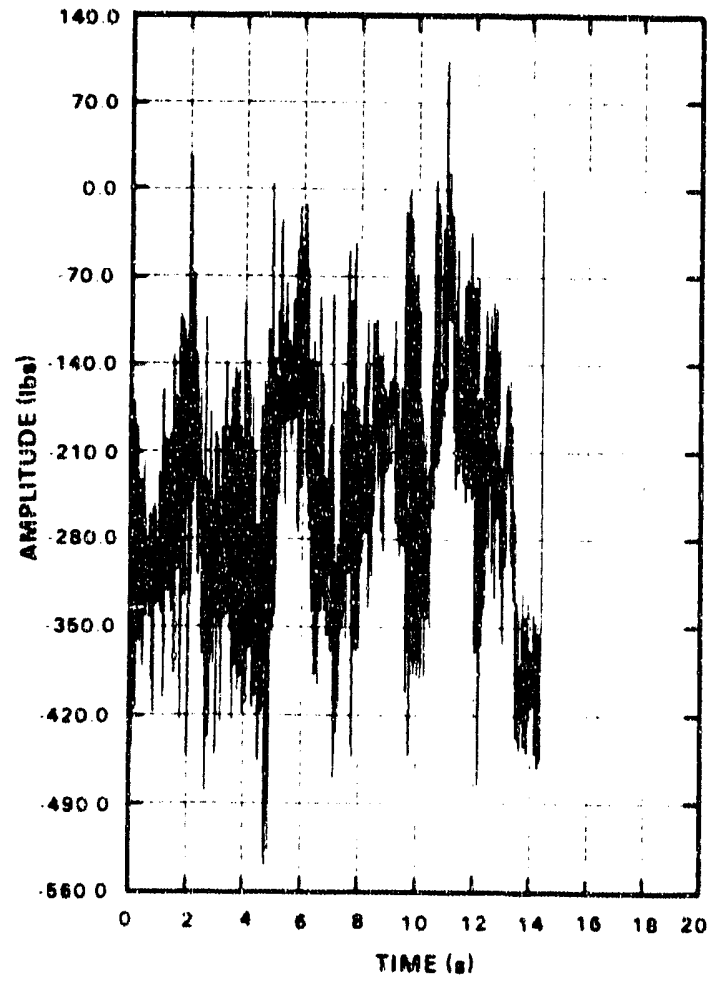

Figure A103 Road Test-CNS 14.170 .1 Cask (Test if Froni Load Cell Loc. 13 , Rough Secondary

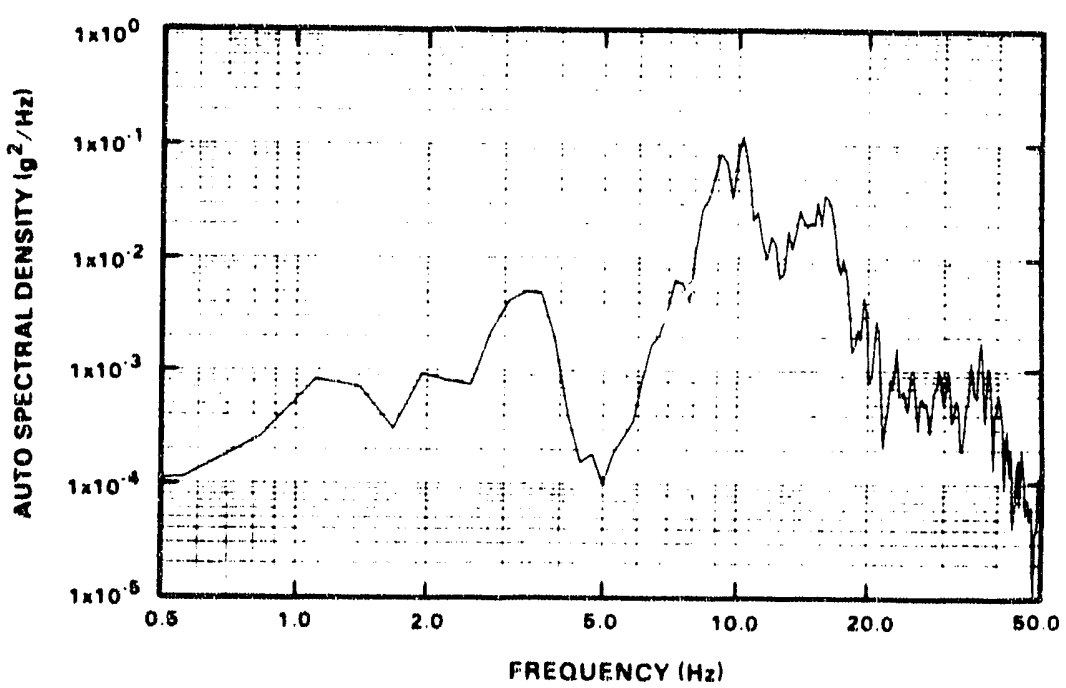

Figure A102. Road Test-CNS 14-170.1 Cask (Test 11 Front Vertical Loc. $\$ 7$; Hough Secondary

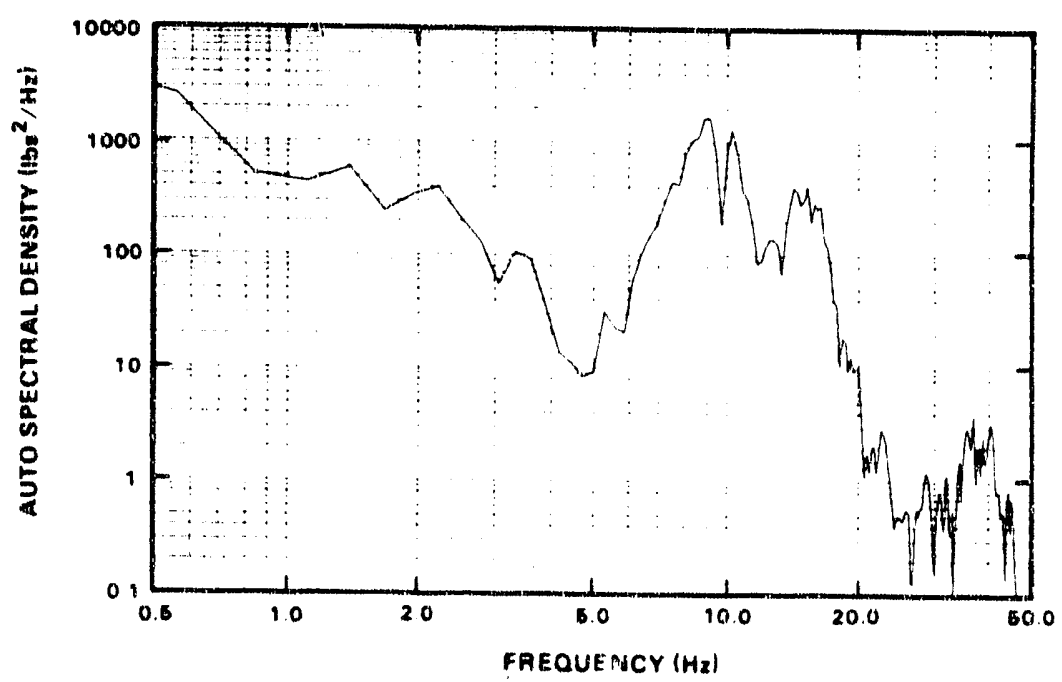

Figure A.104 Road Test-CNS 14.170 .1 Cask (Tesi 1) Front Load Cell Loc H13, Rough Secondary 


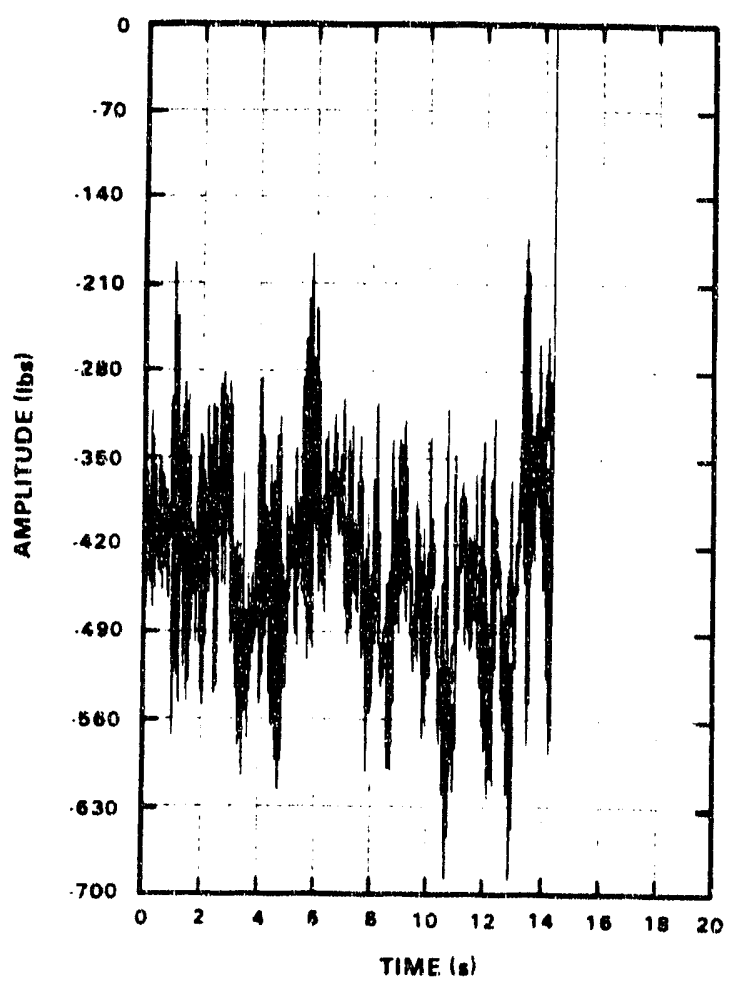

Figure A105. Road Test-CNS 14-170.1 Cask (Test 1) Rear Load Cell LoC. 14, Rough Secondary

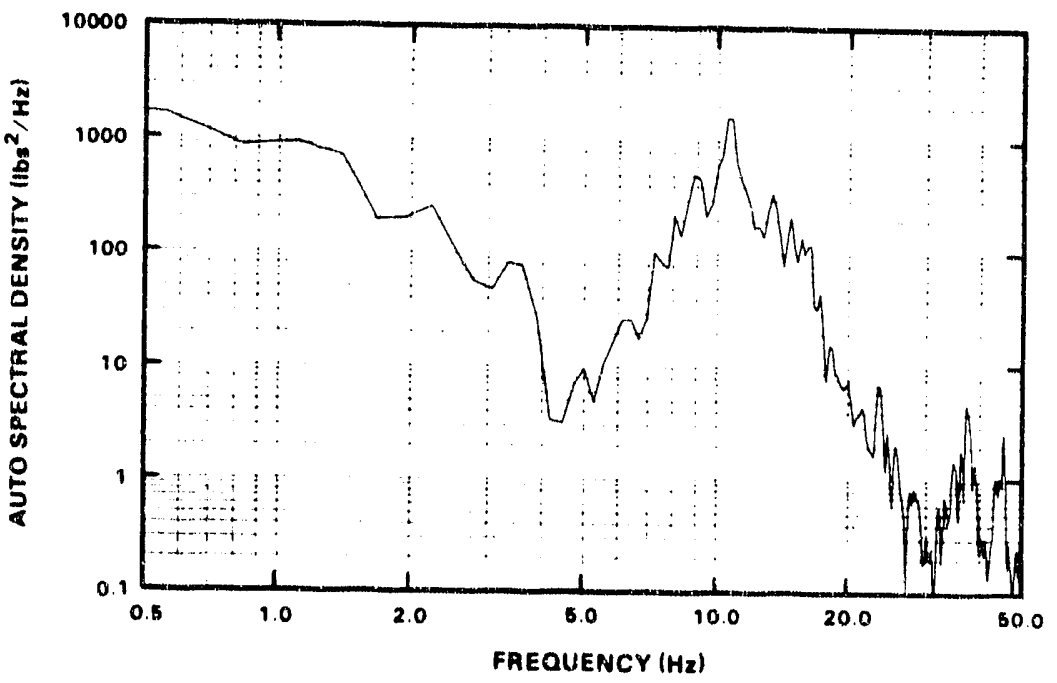

Figure A106. Road Test-CNS 14-170-1 Cask (Test 1) Rear Load Cell Loc. \#14; Rough Secondary 


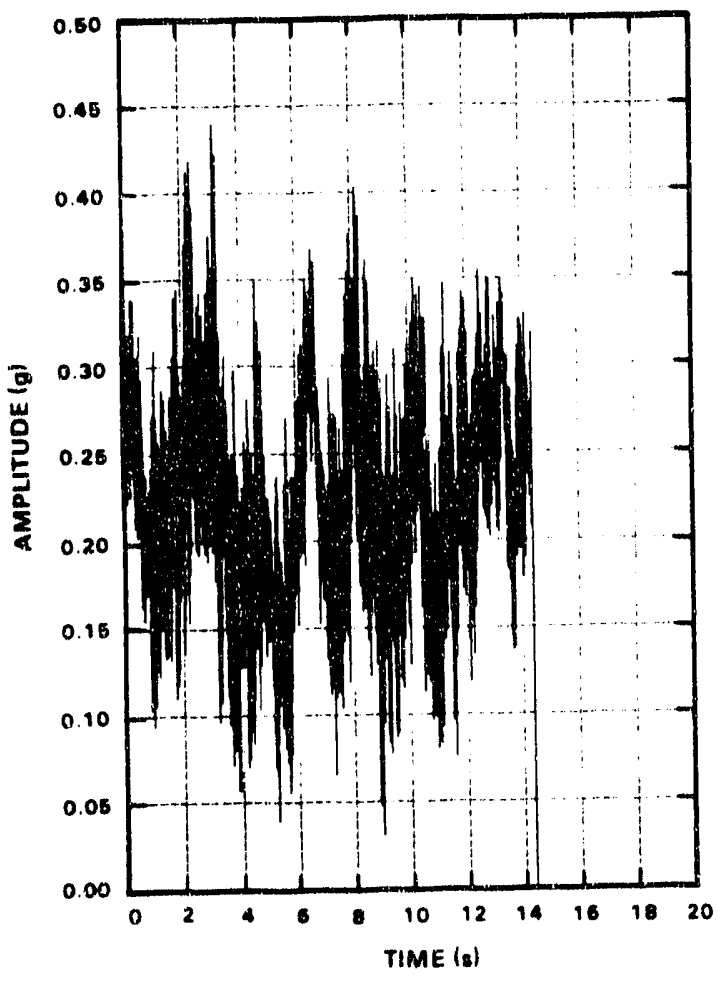

Figure A107 Road Test-CNS 14.170-1 Cask (Test 1) Top Transverse Loc \#1, Spalled Asphal:

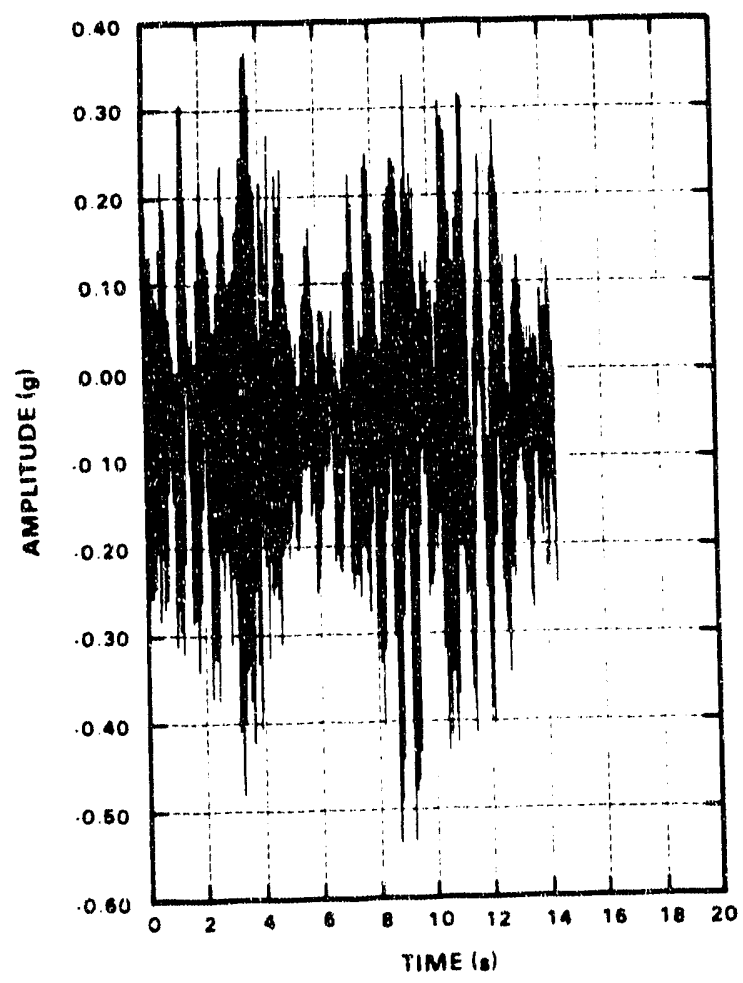

Figure A109. Road Yest-CNS 14.170.1 Cask (Test 1 ) Top Vertical Loc $\$ 2$; Spalled Asphalt

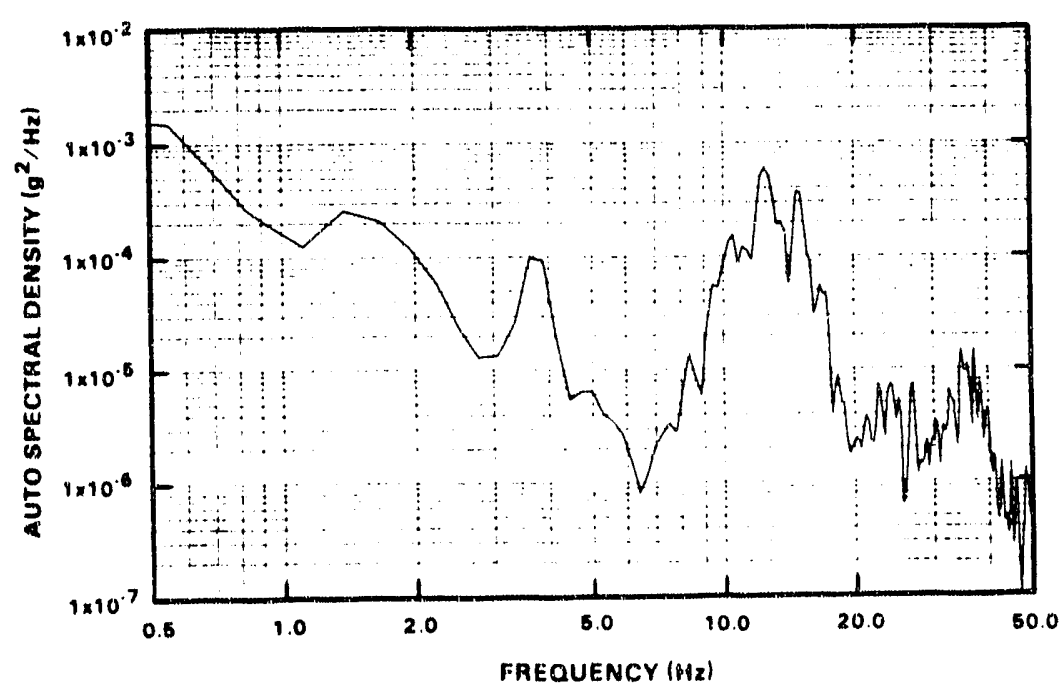

Figure A108. Road Test-CNS 14-170-1 Cask (Test 1) Top Transverse Loc. $\# 1$, Spalled Asphalt

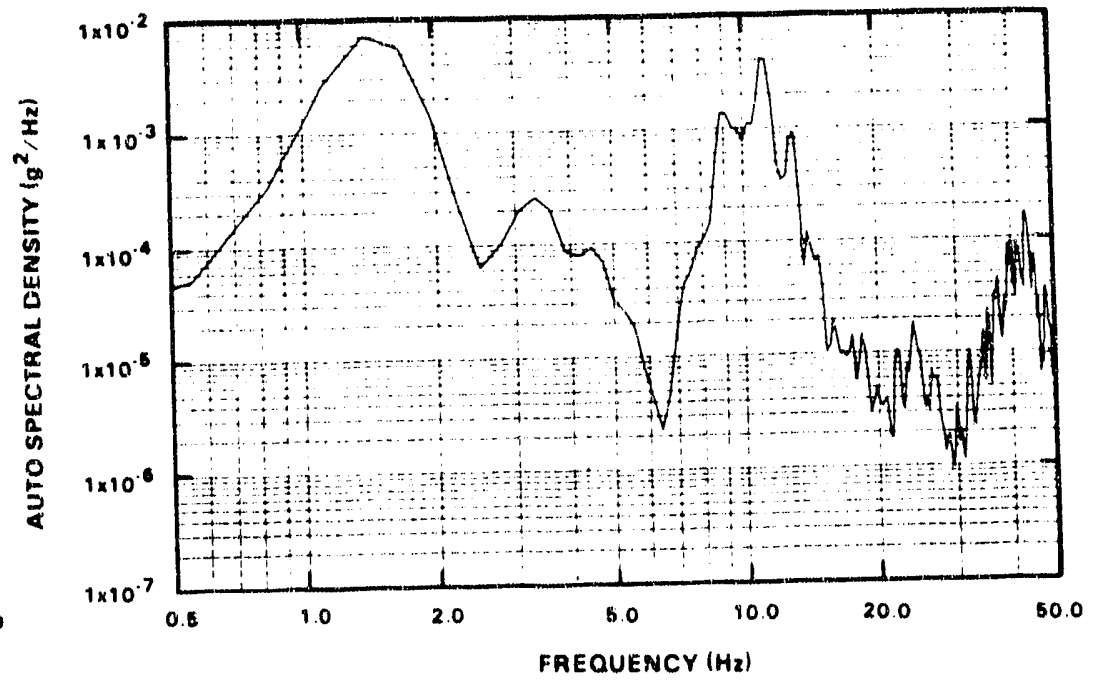

Figure A110. Road Test-CNS 14.170.1 Cask (Test 1) Top Vertical Luc. \#2, Spalled Asphalt 


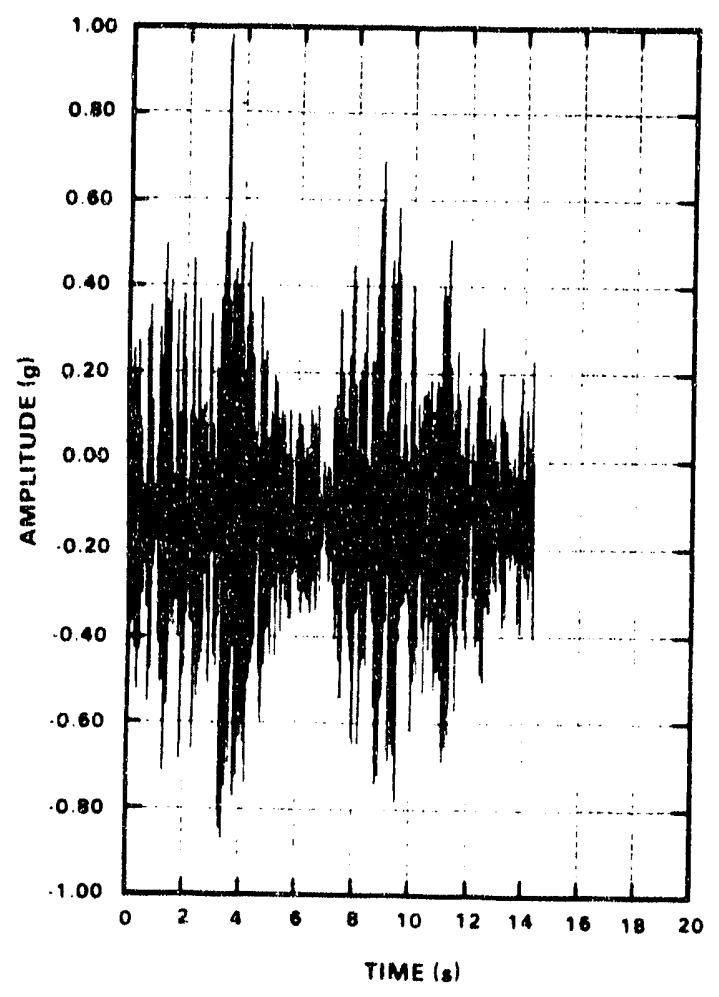

Figure Al11. Road Test.CNS 14.170.1 Cask (Test 1) Top Longitudinal Loc. \#3: Spalled Asphait

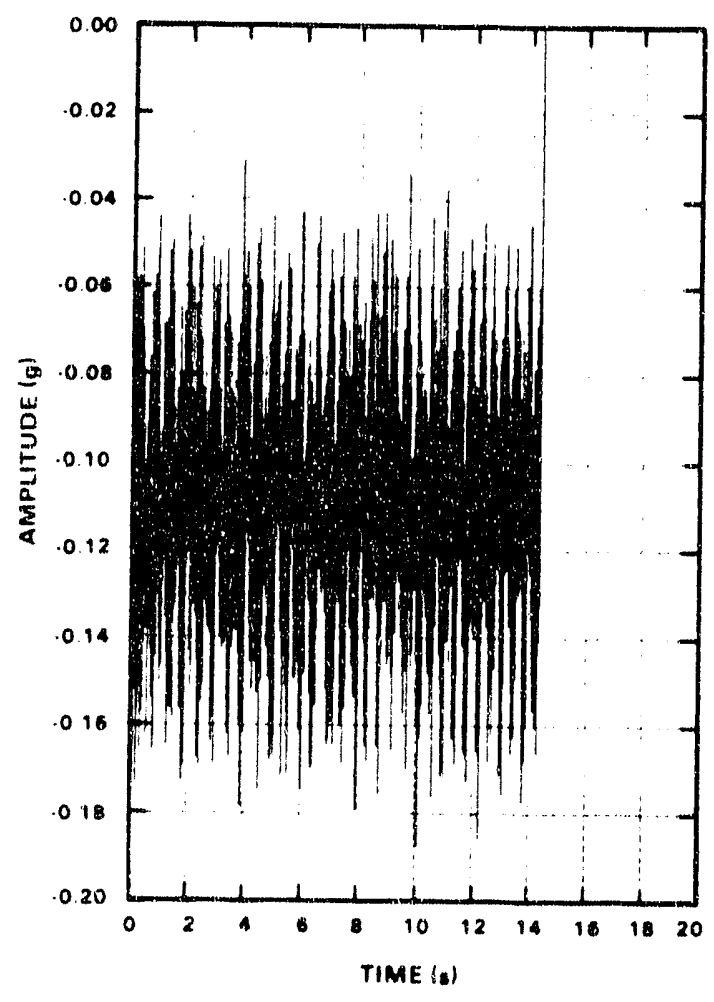

Figure Al13. Road Test.CNS 14.170.1 Cask (Test 1 ) Mid Vertical Loc. \$4. Spalled Asphait

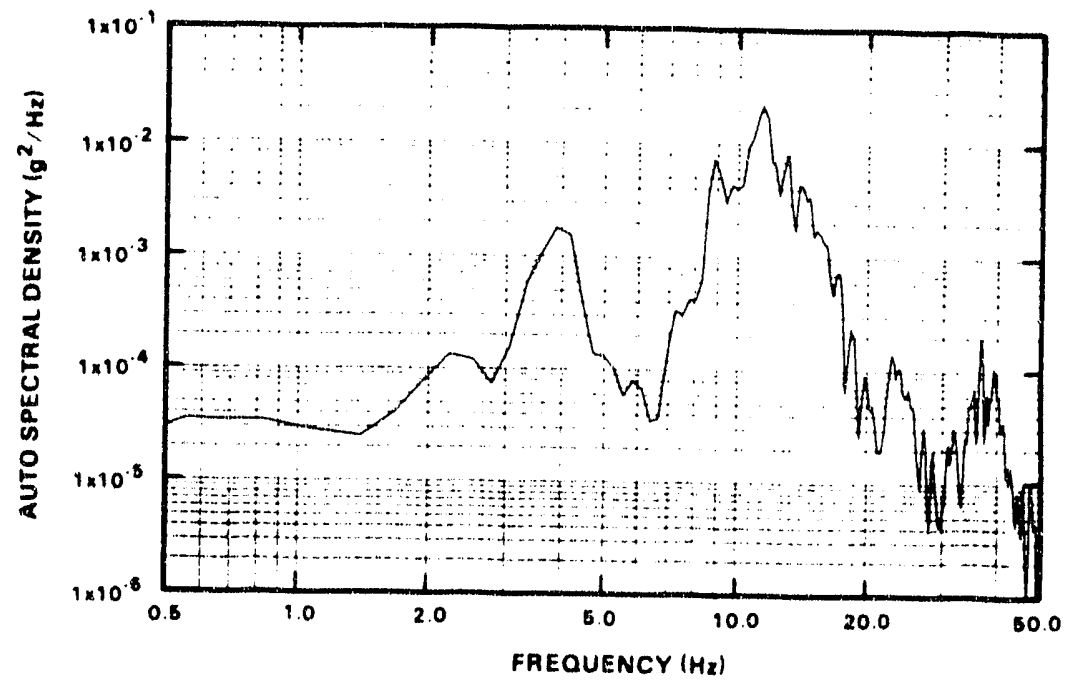

Figure A1 12. Road Test-CNS 14.170.1 Cask (Test 1 ) Top Longitudinal Loc 43 ; Spalled Asphait

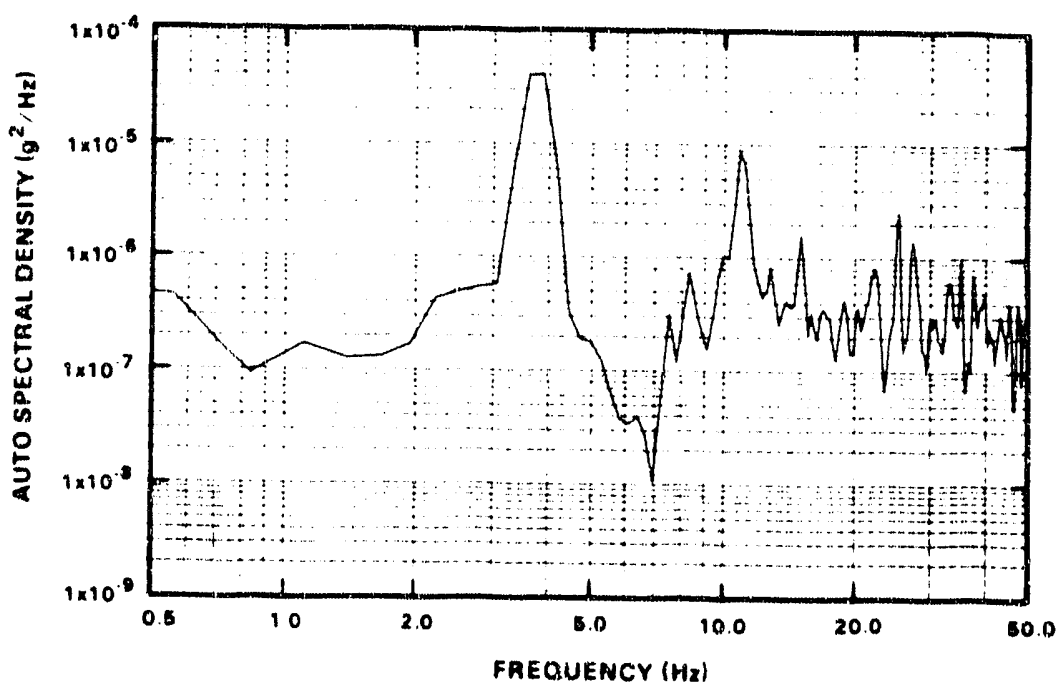

Figure A114. Road Test-CNS $14.170-1$ Cask (Tost 1) Mid Vertical Loc. 4; Spalled Asphait 


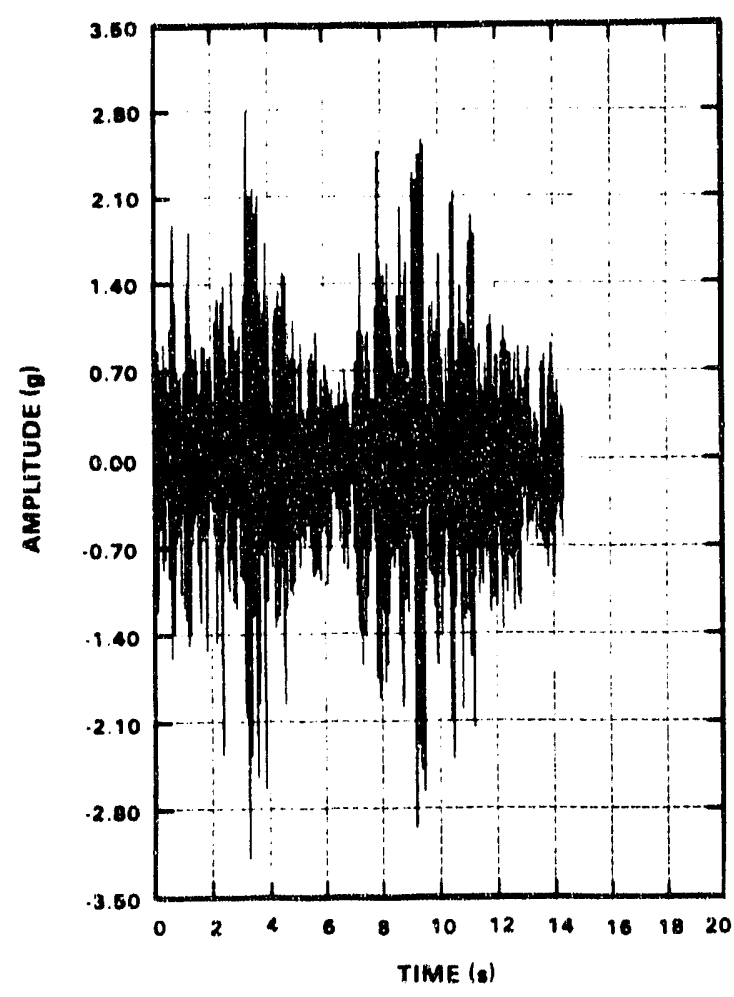

Figure A1 15. Road Test-CNS 14.170-1 Cask (Test 1) Rear Vertical Loc. \#5; Spalled Asphalt

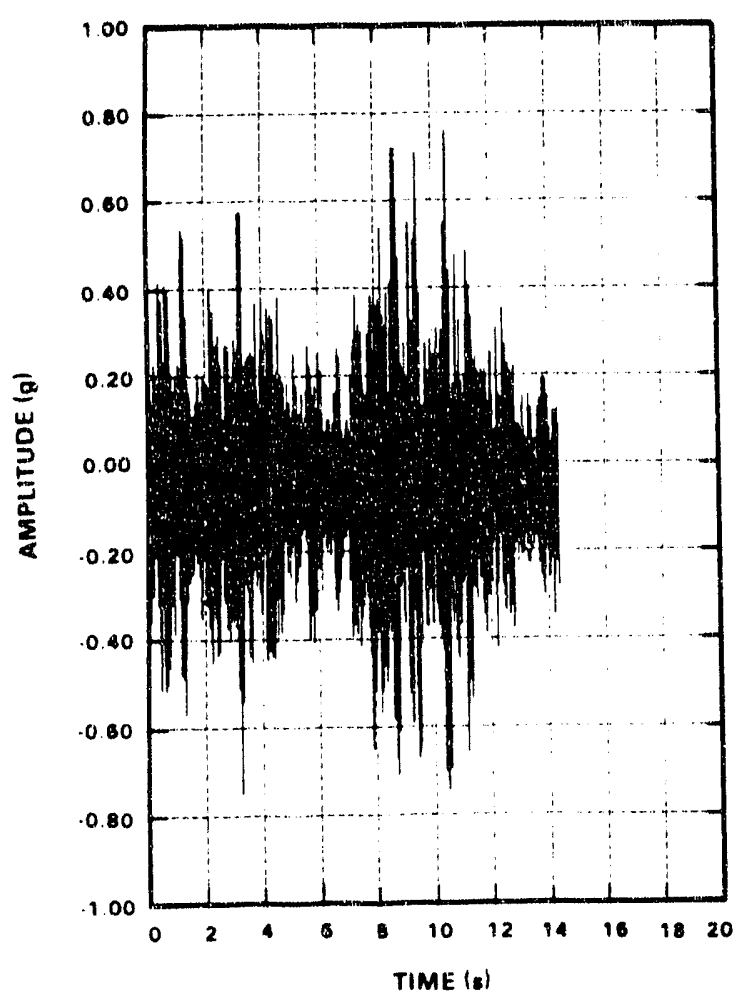

Figure Al17 Road Test-CNS 14.170.1 Cask (Test 1 ) Rear Longiludinal Loc $\# 6$; Spalled Asphalt

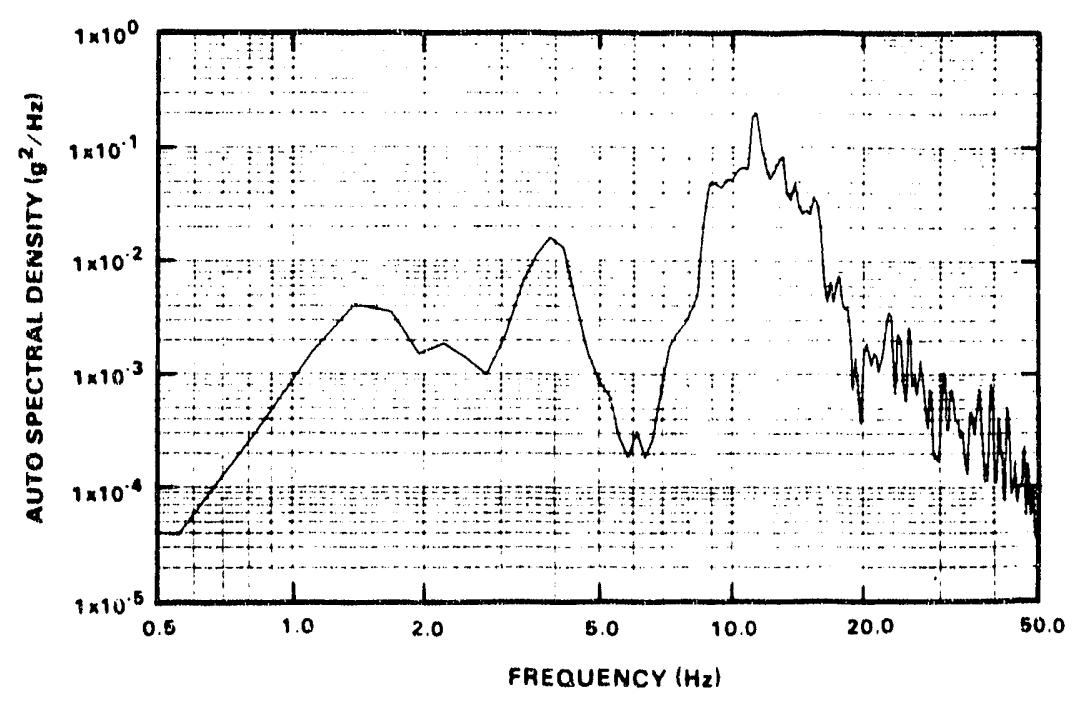

Figure A116. Road Test-CNS 14.170.1 Cask (Test 1 ) Rear Vertical Loc. 45 ; Spalled Asphalt

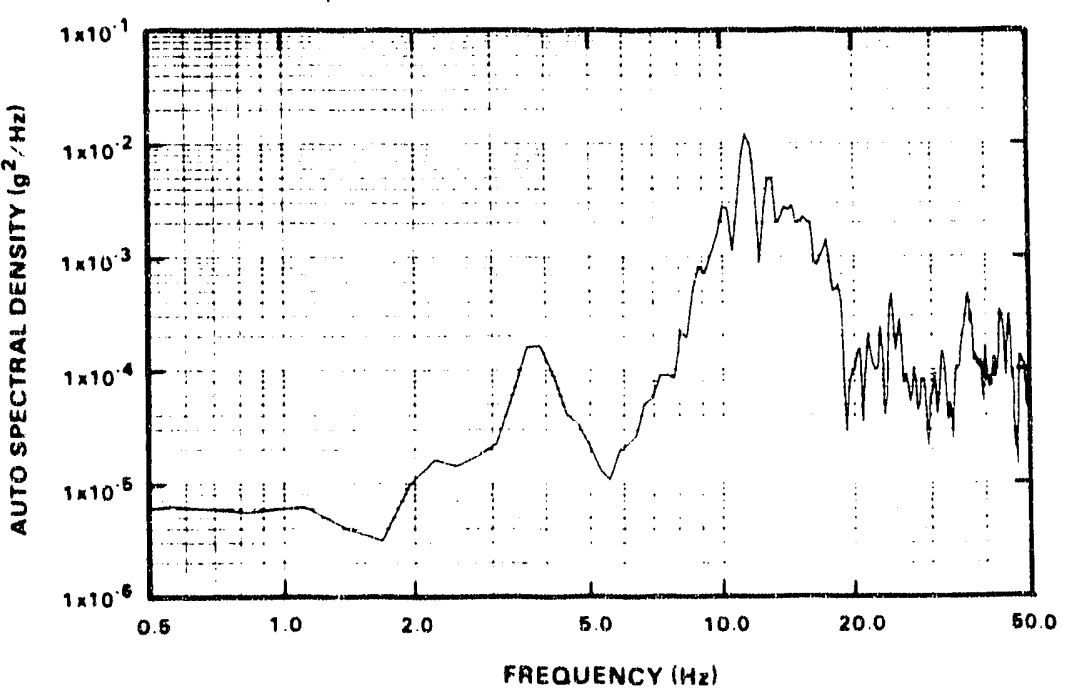

Figure A1 18 Road Test.CNS 14.170.1 Cask (Test 1 ) Rear Longitudina! Loc $\sharp 6$, Spalled Asphait 


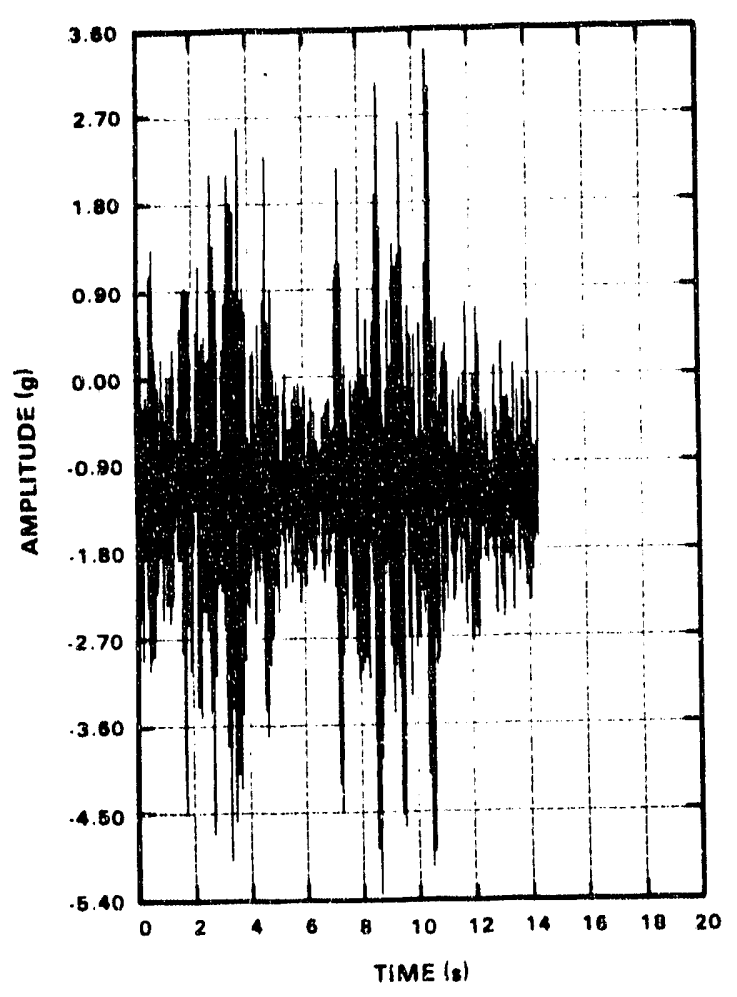

Figure A1 19 Road Test-CNS 14.170.1 Cask (Test 1) Front Vertical Loc. 77 ; Spalled Asphalt

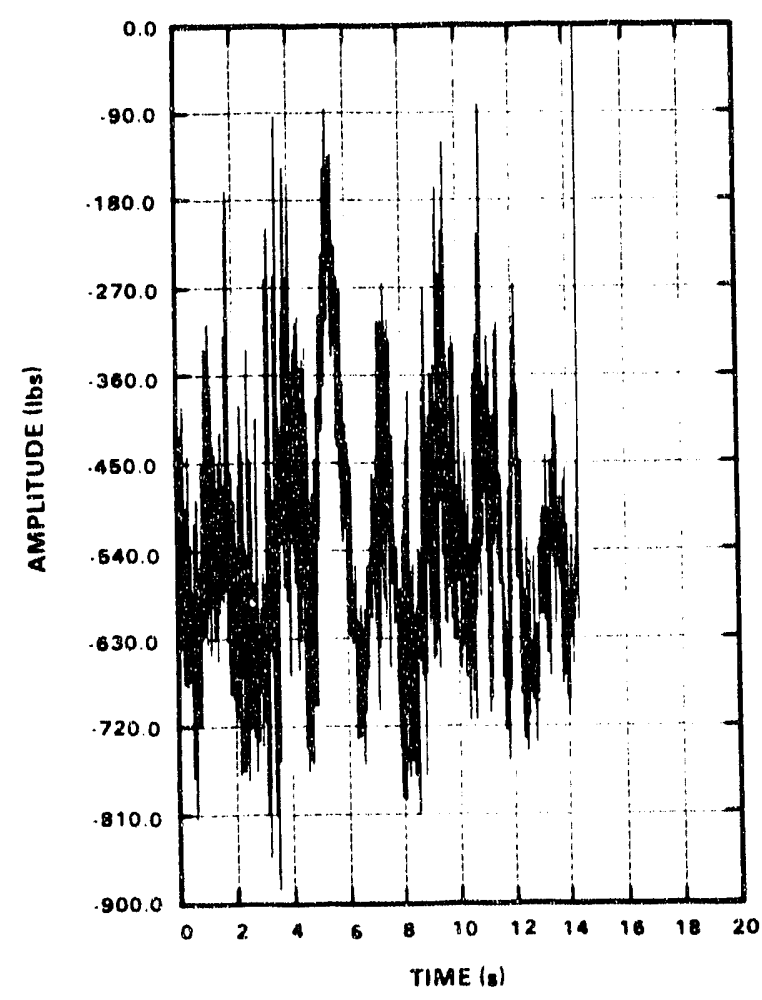

Figure A121. Road Tesi-CNS 14-170.1 Cask (Test 1) Front load Cell Loc $\# 13$. Spalled Asphalt

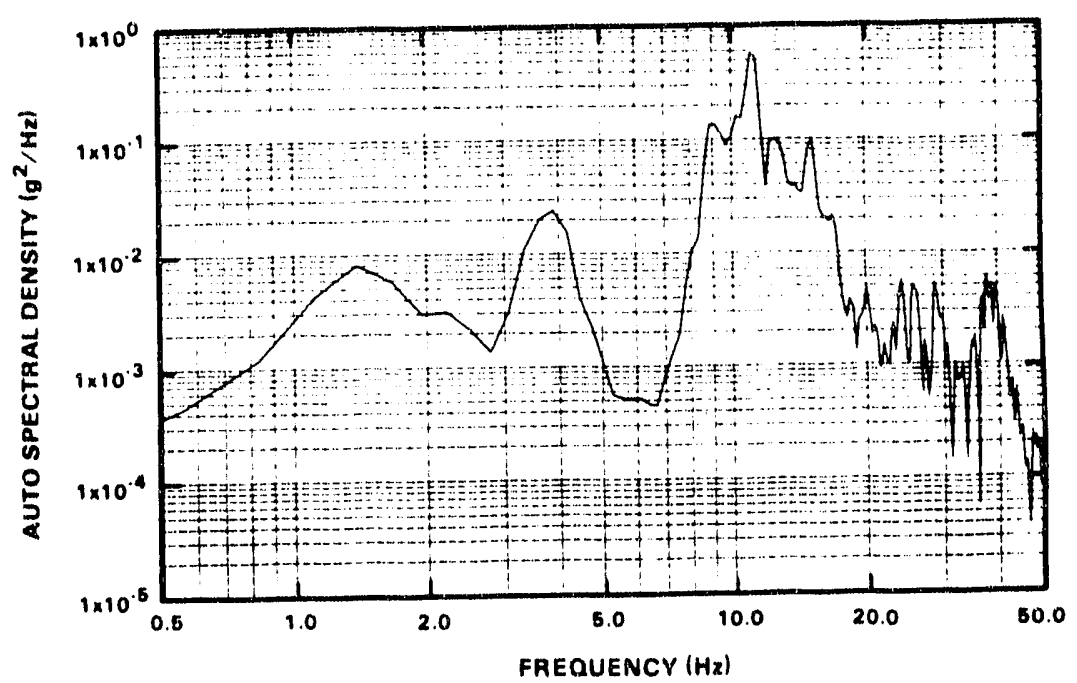

Figure A120. Road Test-CNS 14.170.1 Cask (Test 1) Front Vertical Loc. \#7; Spalled Asphalt

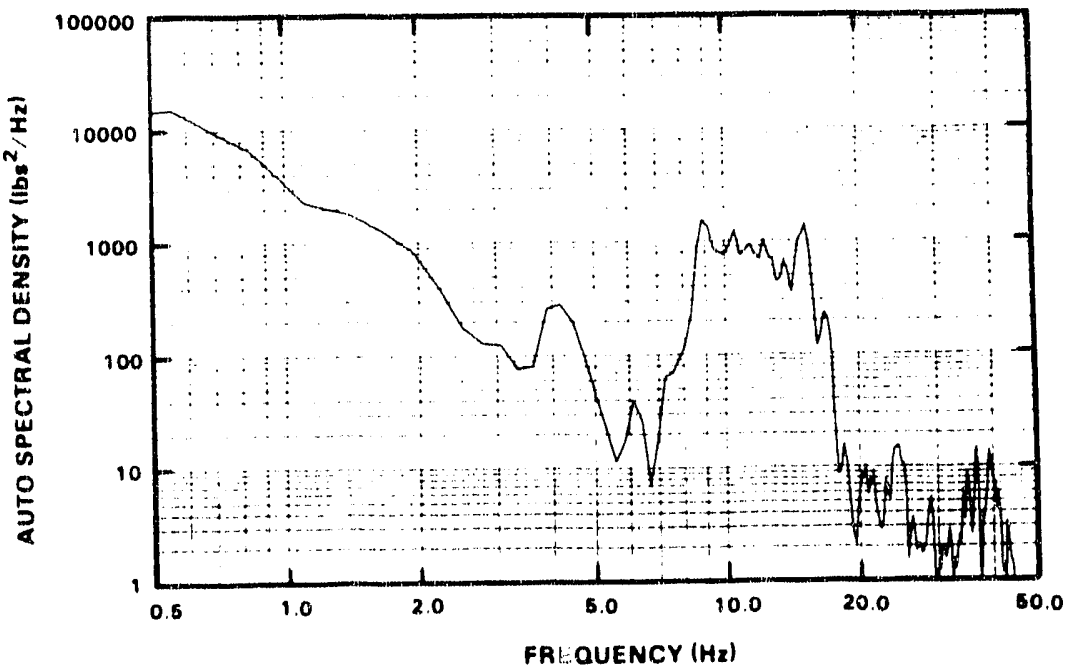

Figure A122. Road Test.CNS 14.170.1 Cask (Test II Front Load Cell Loc H13: Spalled Asphall 


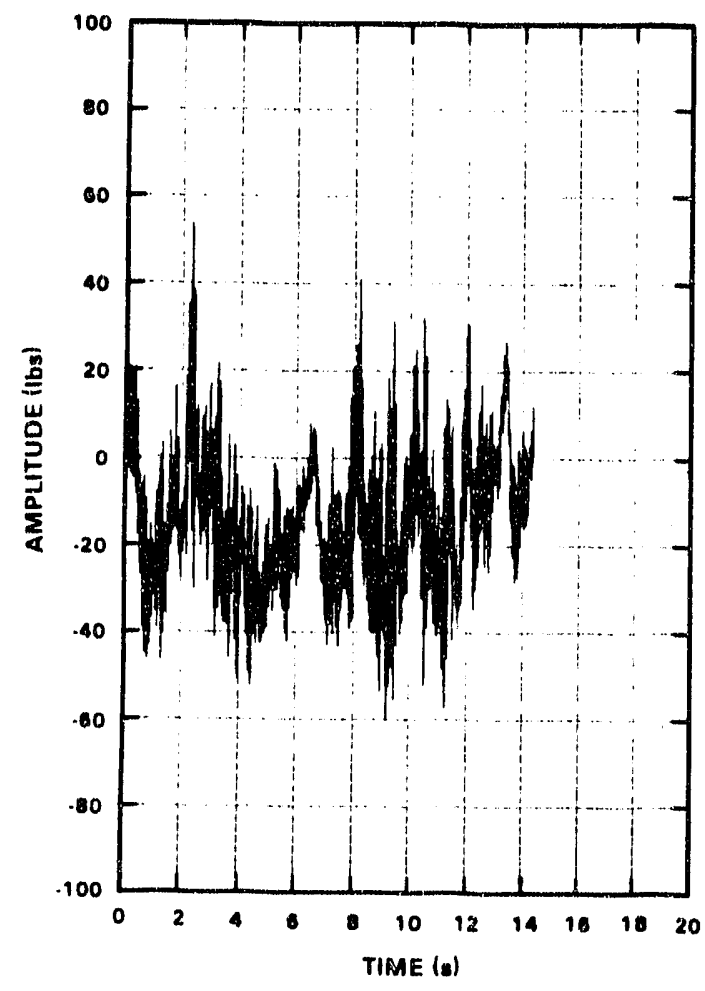

Figure A123. Poad Test-CNS 14-170-1 Cask (Test 1) Rear Load Cell Loc. \#14; Spalled Asphalt

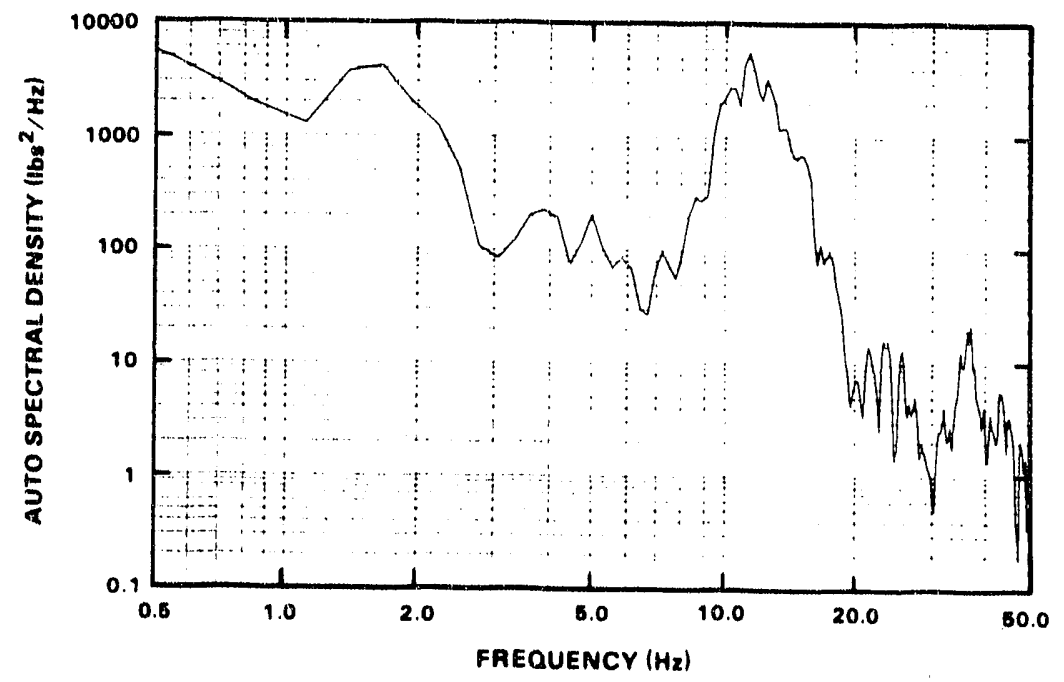

Figure A124. Road Test-CNS 14-170.1 Cask (Test 1) Rear L.oad Cell Loc. H14; Spalled Asphalt 


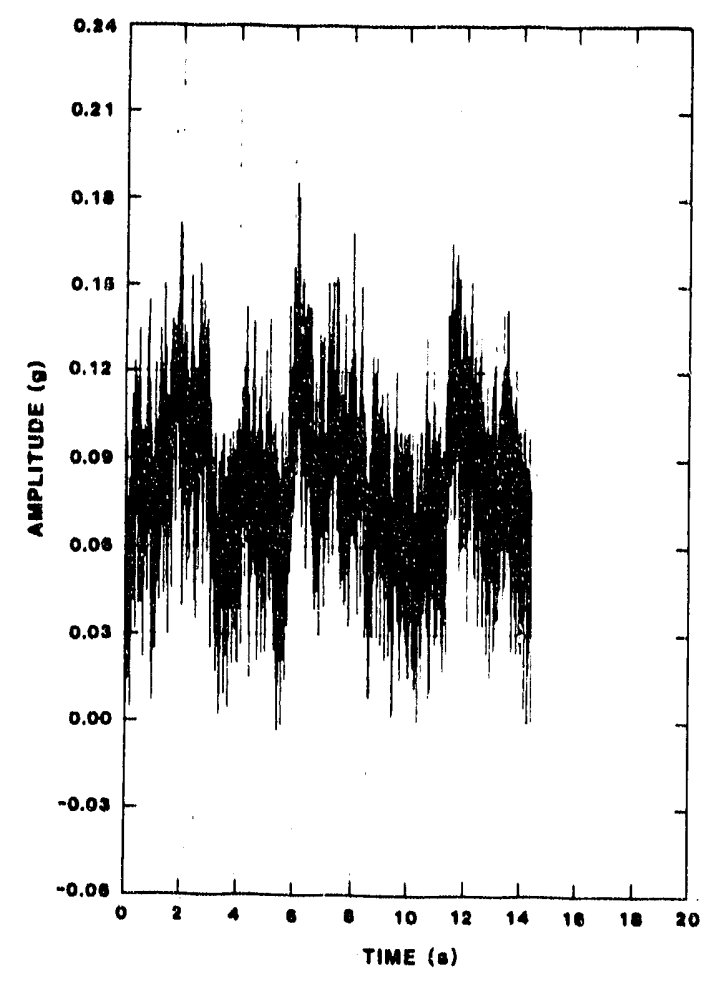

Figure B1. Road Test-CNS 3-55 Cask (Test 2) Top Transverse Loc. \#1; Smooth Asphalt

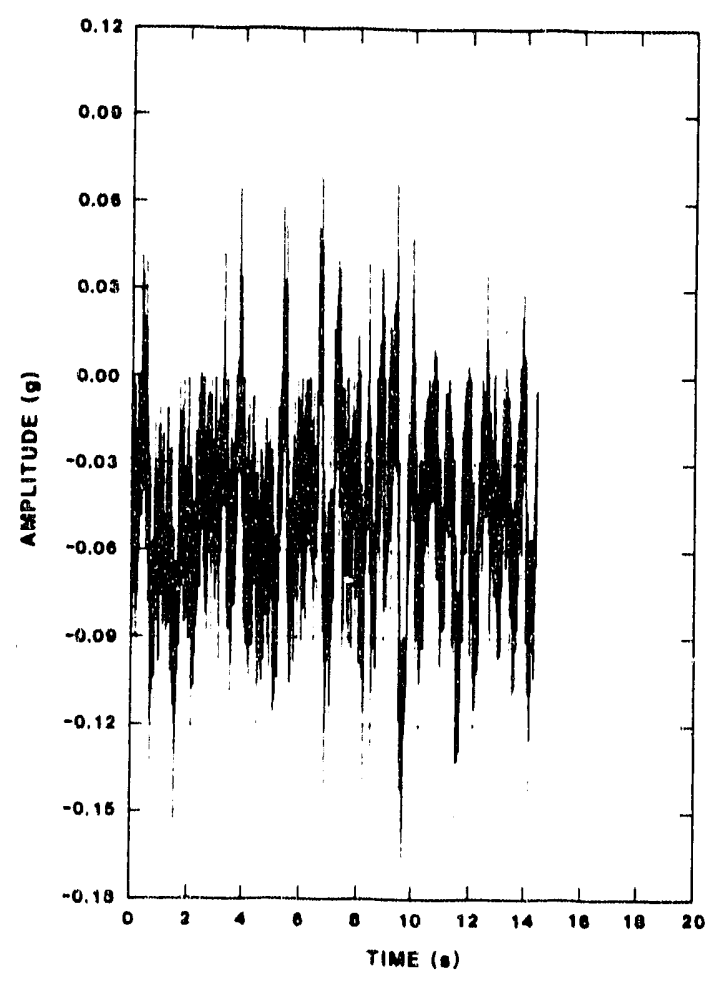

Figure B3. Road Test-CNS 3-55 Cask (Test 2) Top Vertical Loc. 2; Smooth Asphait

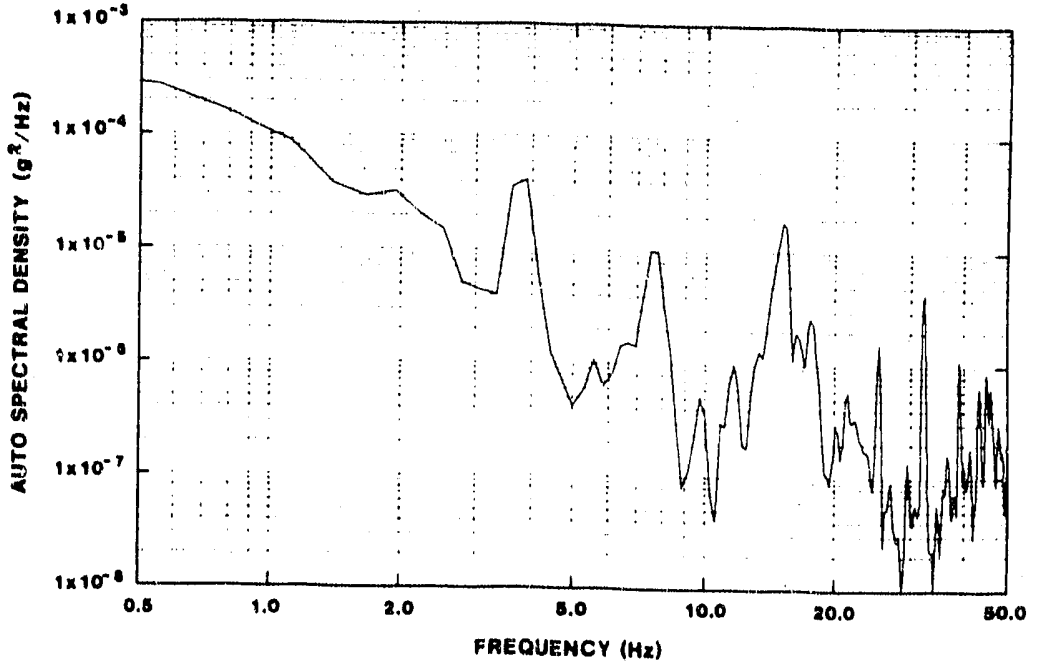

Figure B2. Road Test-CNS 3-55 Cask (Test 2)

Top Transverse Loc. \#1; Smooth Asphalt

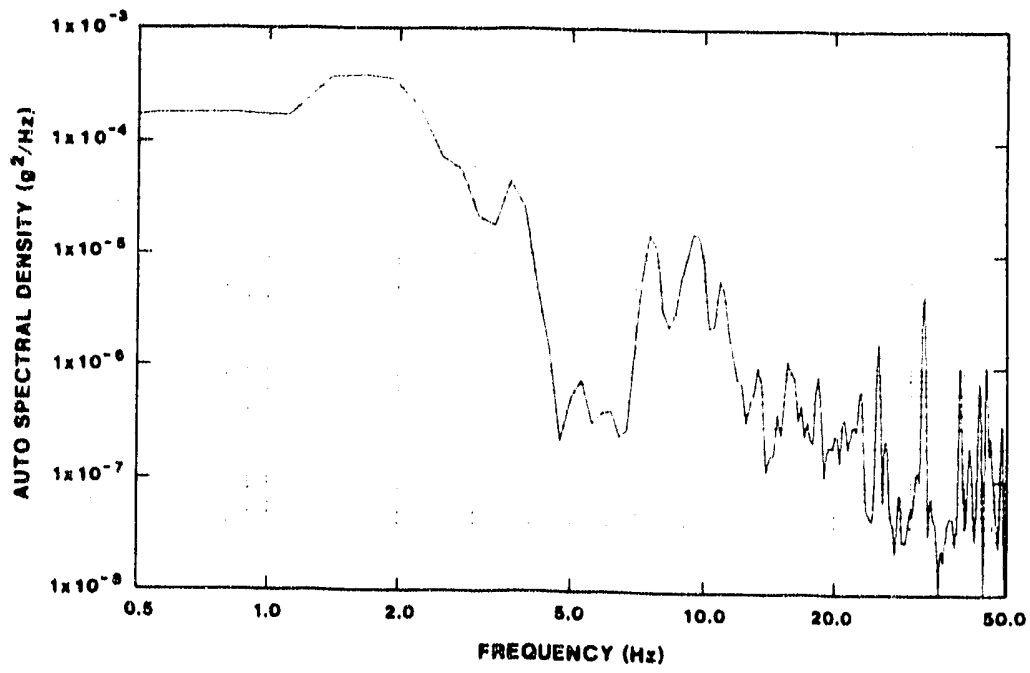

Figure B4. Road Tesi-CNS 3-55 Cask (Test 2)

Top Vertical Loc. \#2; Smooth Asphalt 


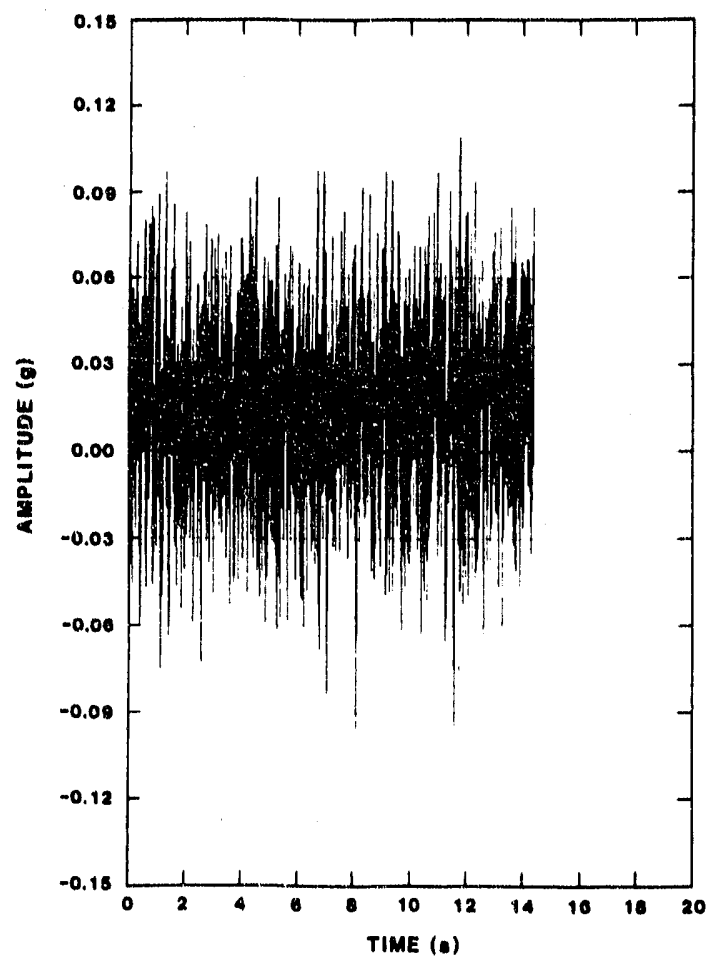

Figure B5. Road Test-CNS 3-55 Cask (Test 2) Top Longitudinal Loc. \#3; Smooth Asphalt

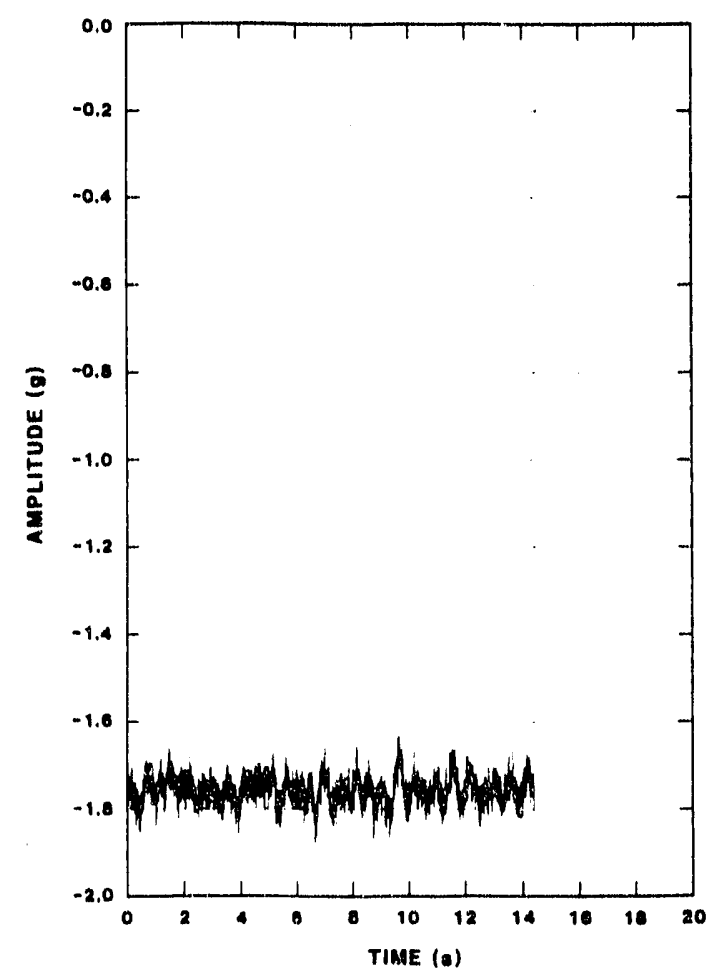

Figure 87. Ruad Test-CNS 3-55 Cask (Test 2) Mid Vertical Loc. "4; Smooth Asphalt

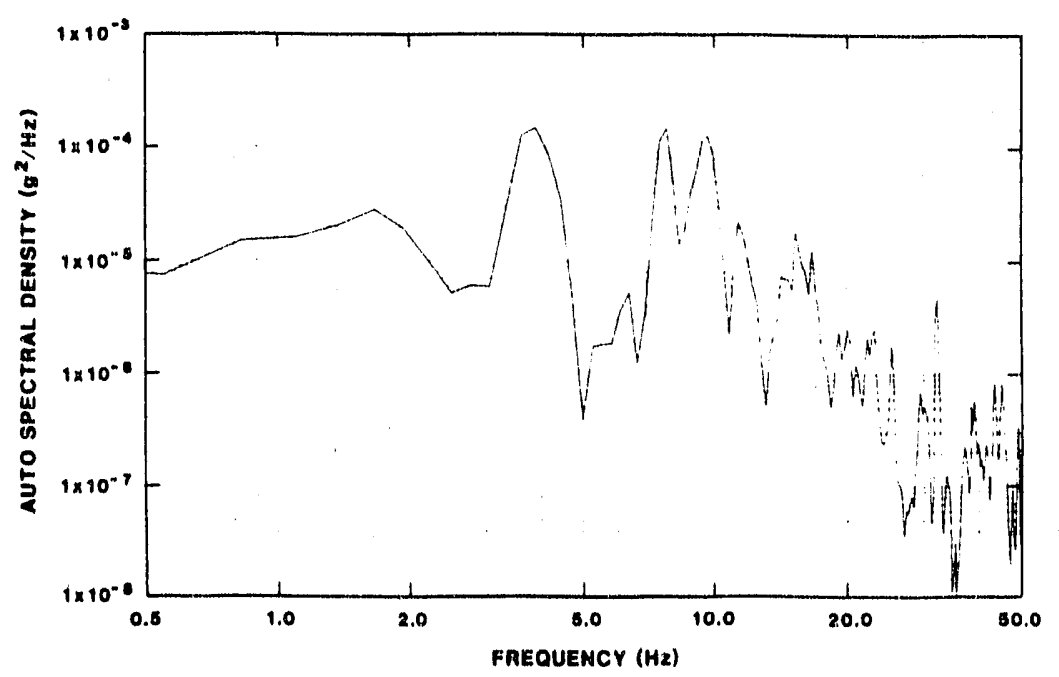

Figure B6. Road Test-CNS 3-55 Cask (Test 2) Top Longitudinal Loc. \#3; Smooth Asphalt

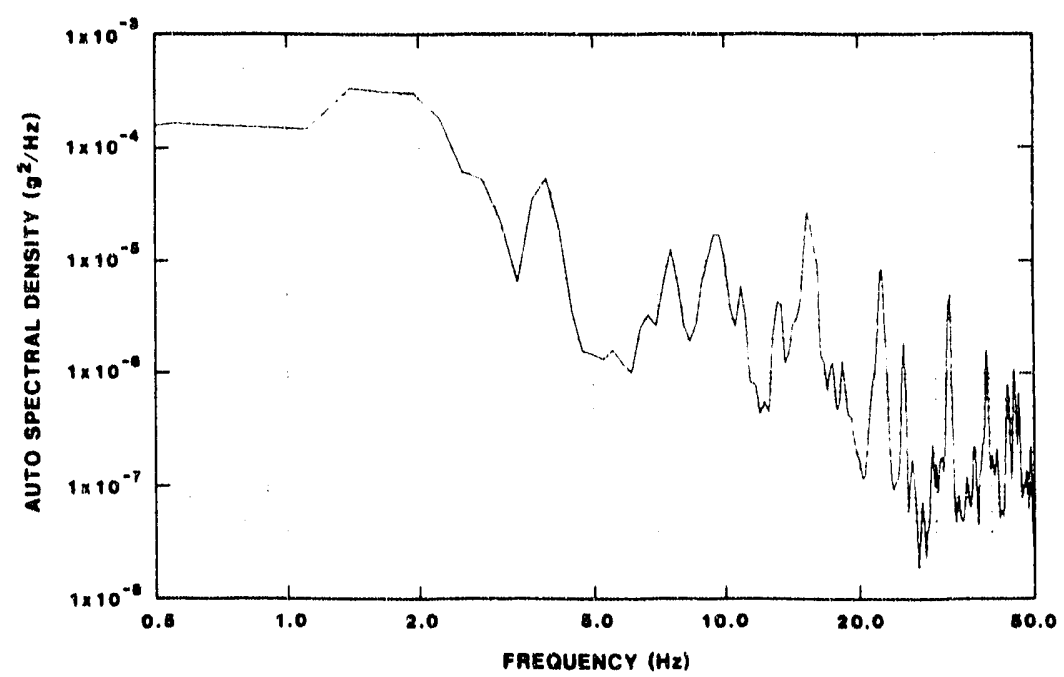

Figure B8. Road Test-CNS 3-55 Cask (Test 2) Mid Vertical LOC. "4; Smooth Asphalt 


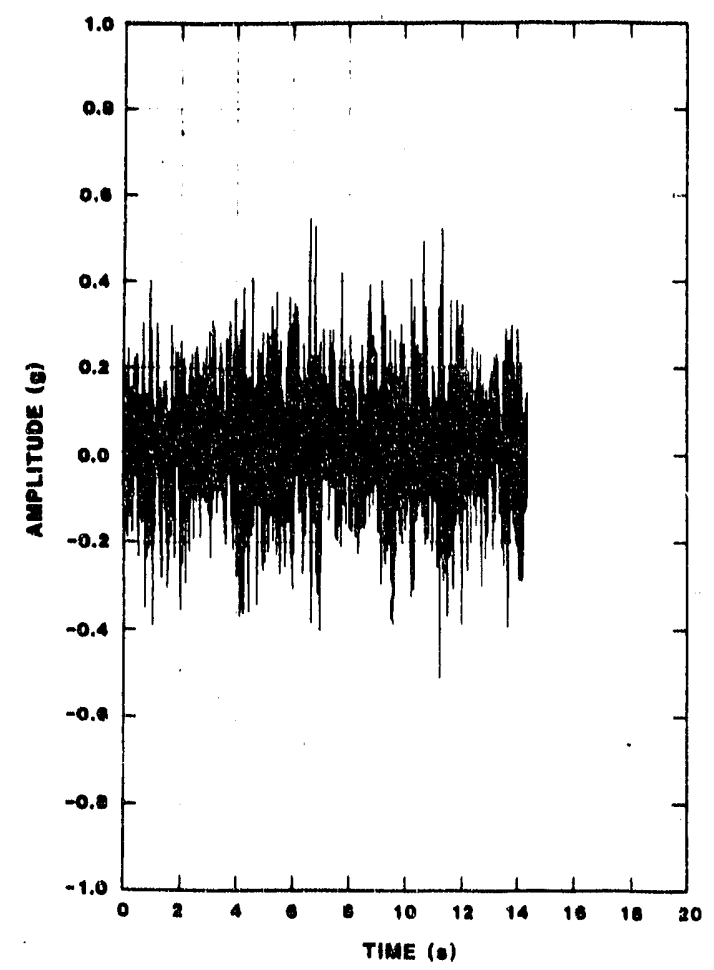

Figure 89. Road Test-CNS 3-55 Cask (Test 2) Pear Vertical Loc. 5 ; Smooth Asphait

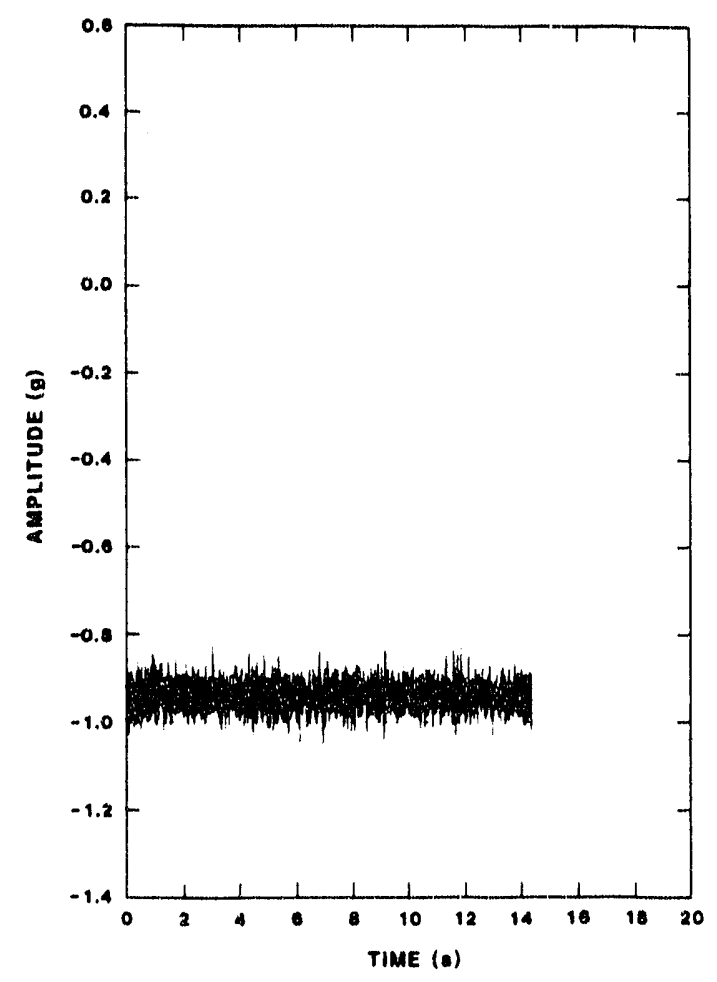

Figure B11. Road Test-CNS 3-55 Cask (Test 2) Rear Longitudinal Loc. 66 ; Smooth Asphalt

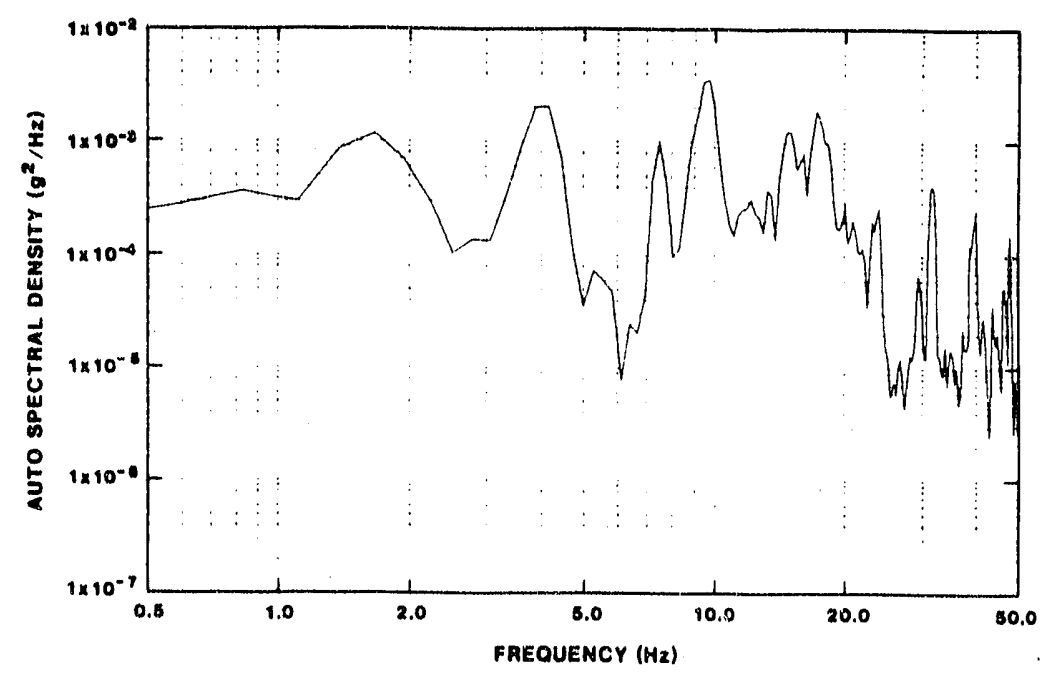

Figure B10. Road Test-CNS 3-55 Cask (Test 2) Rear Vertical Loc. \#5; Smooth Asphalt

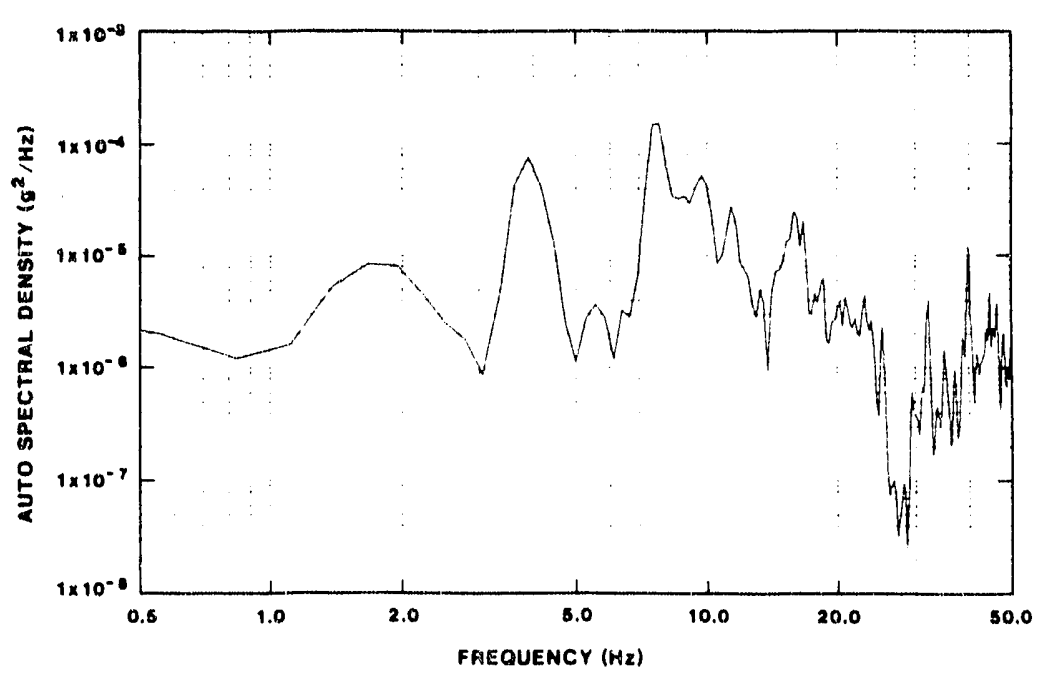

Figure B12. Road Tes:-CNS 3-55 Cask (Test 2) Rear Longitudinal Loc. "6; Smooth Asphalt 


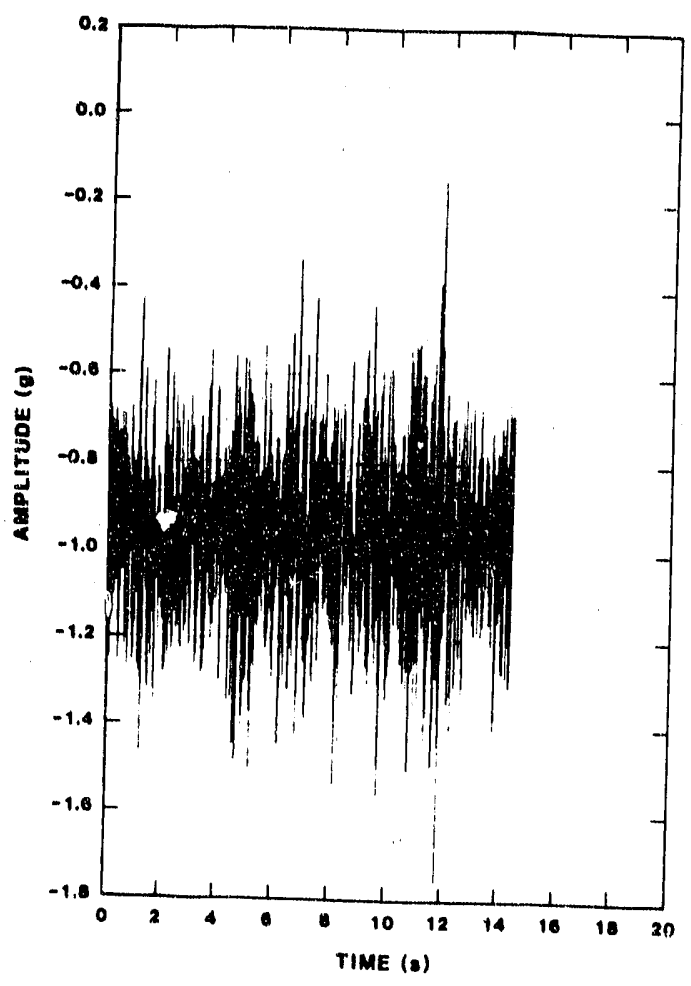

Figure B13. Road Test-CNS 3-55 Cask (Tast 2) Front Vertical Loc. \#7; Smooth Asphalt

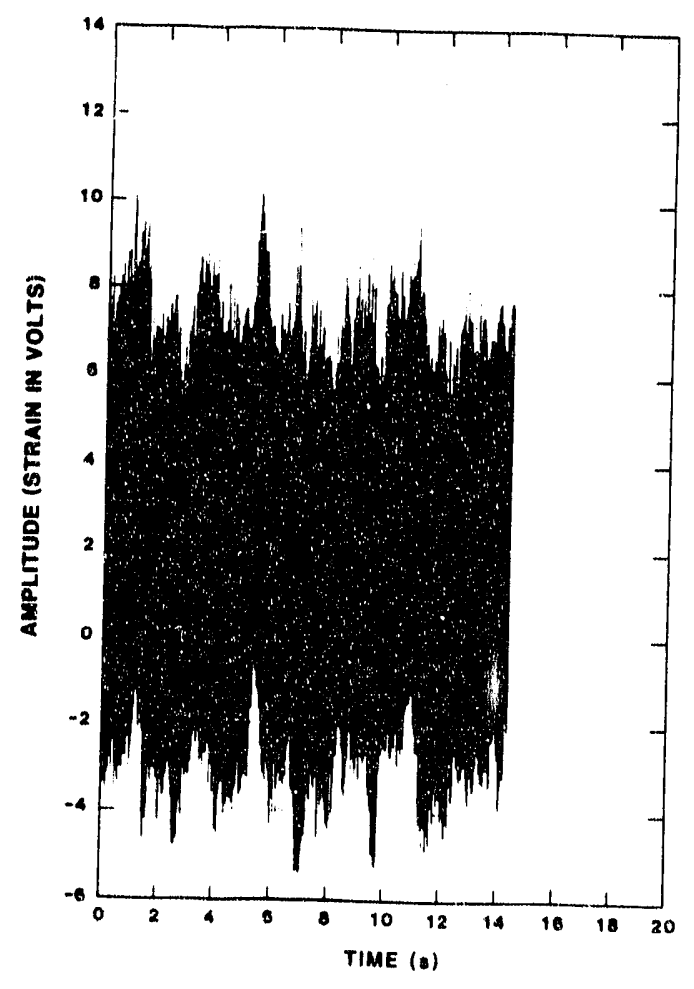

Figure B15. Road Test-CNS 3-55 Cask (Test 2) Front Strain Qage Loc. \#13; Smooth Asphalt

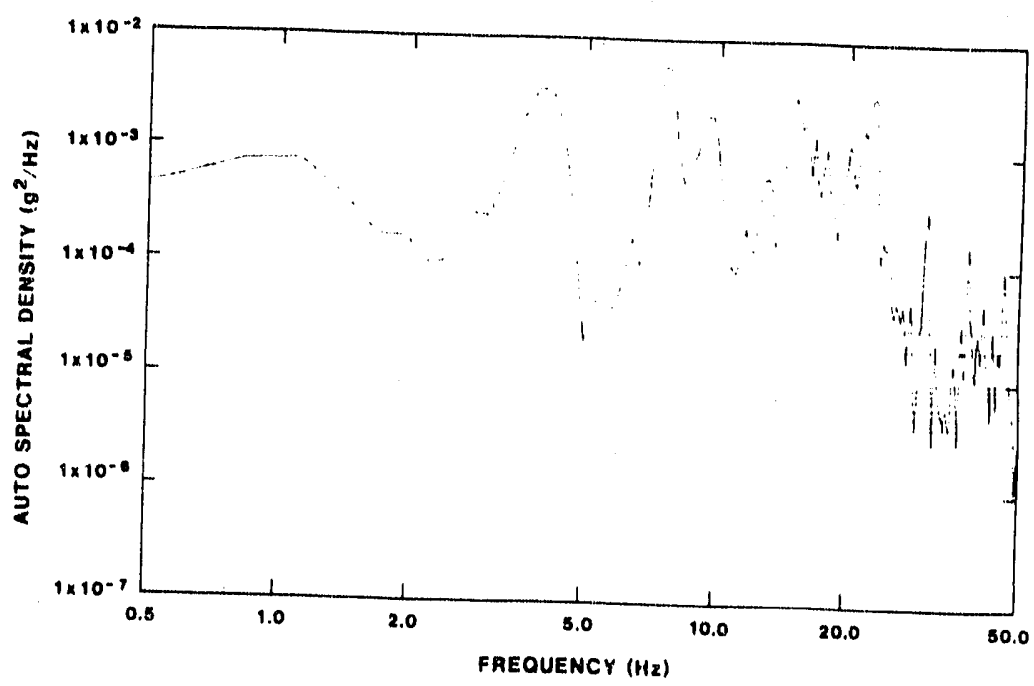

Figure B14. Road Test-CNS 3-55 Cask (Test 2) Front Vertical Loc. \#7; Smooth Asphalt

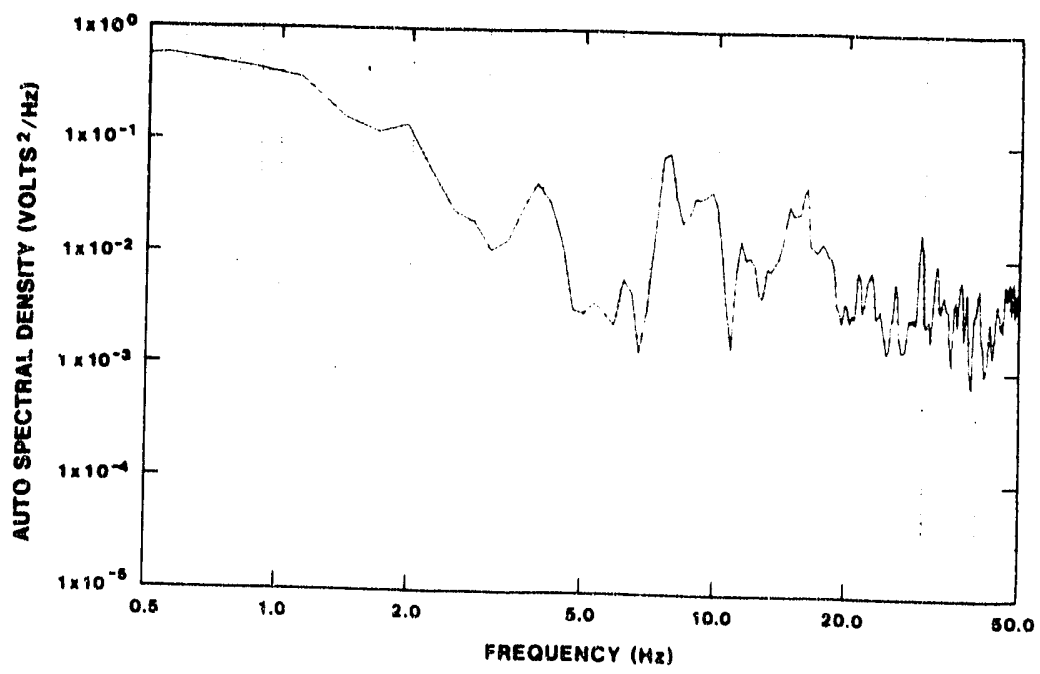

Figure B16. Road Test-CNS 3-55 Cash (Test 2) Front Sirain Gage Loc. 13: Smooth Asphalt 


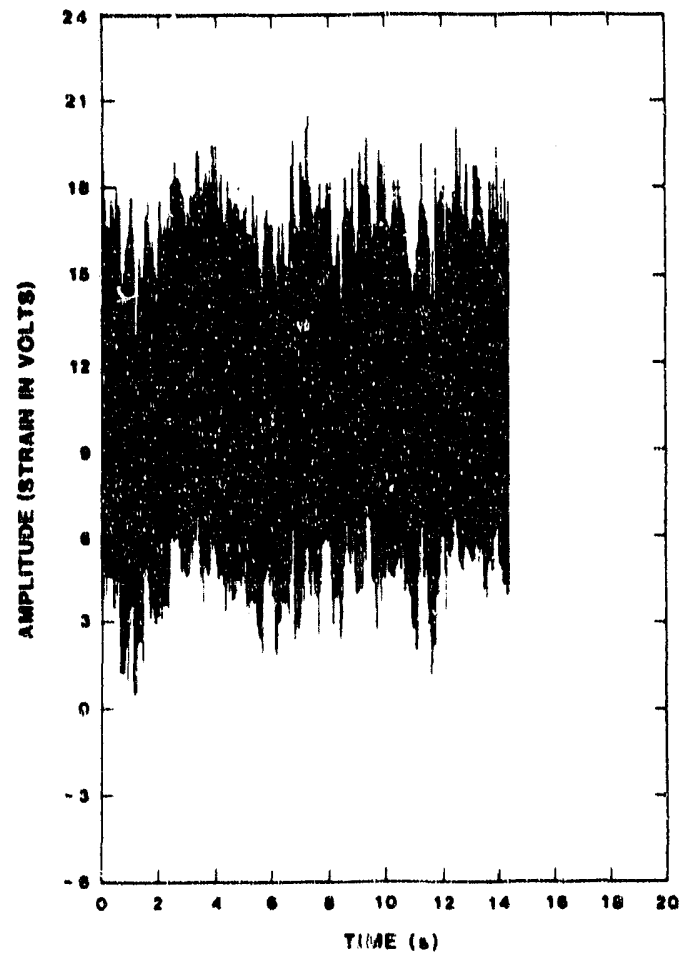

Figure 81\%. Road Test-CNS 3-55 Cask (Test 2) Rear Strain Gage Loc. 14: Smooth Asphalt

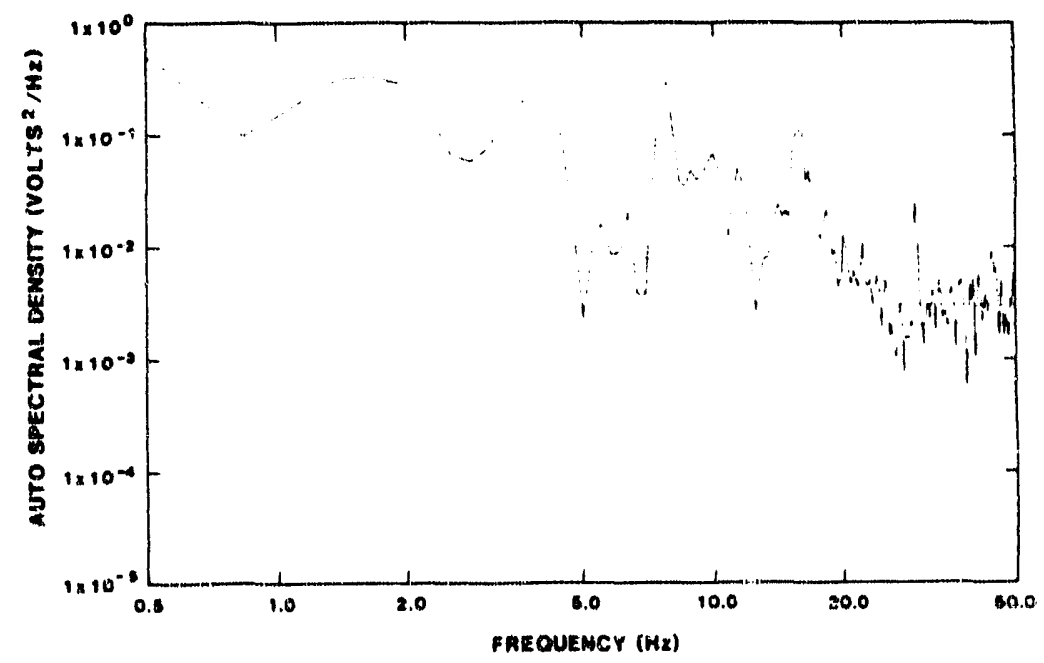

Figure B18. Poad Test-CNS 3-55 Cask (Test 2) Piear Strain Gage Loc. 14; Smooth Asphalt 

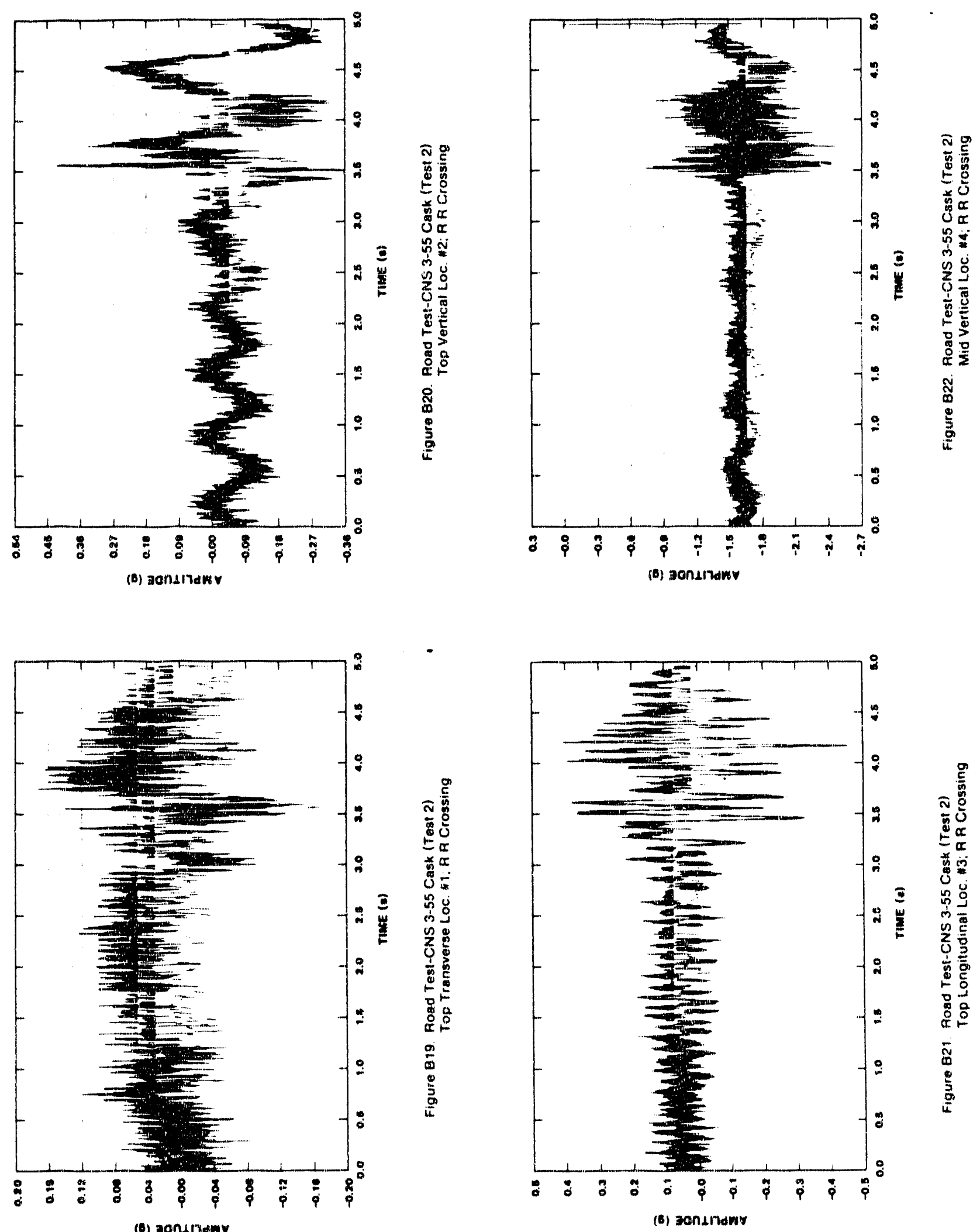

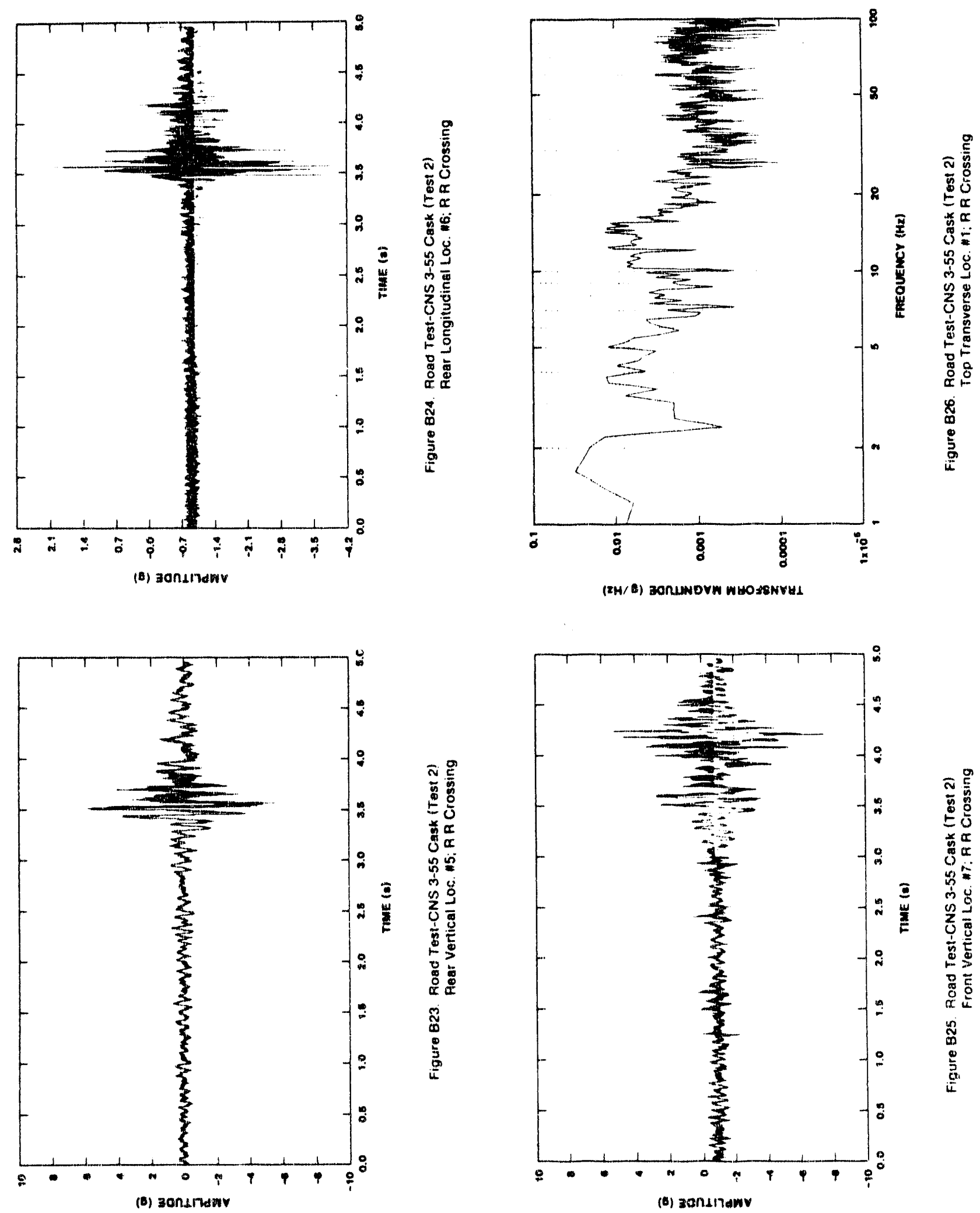

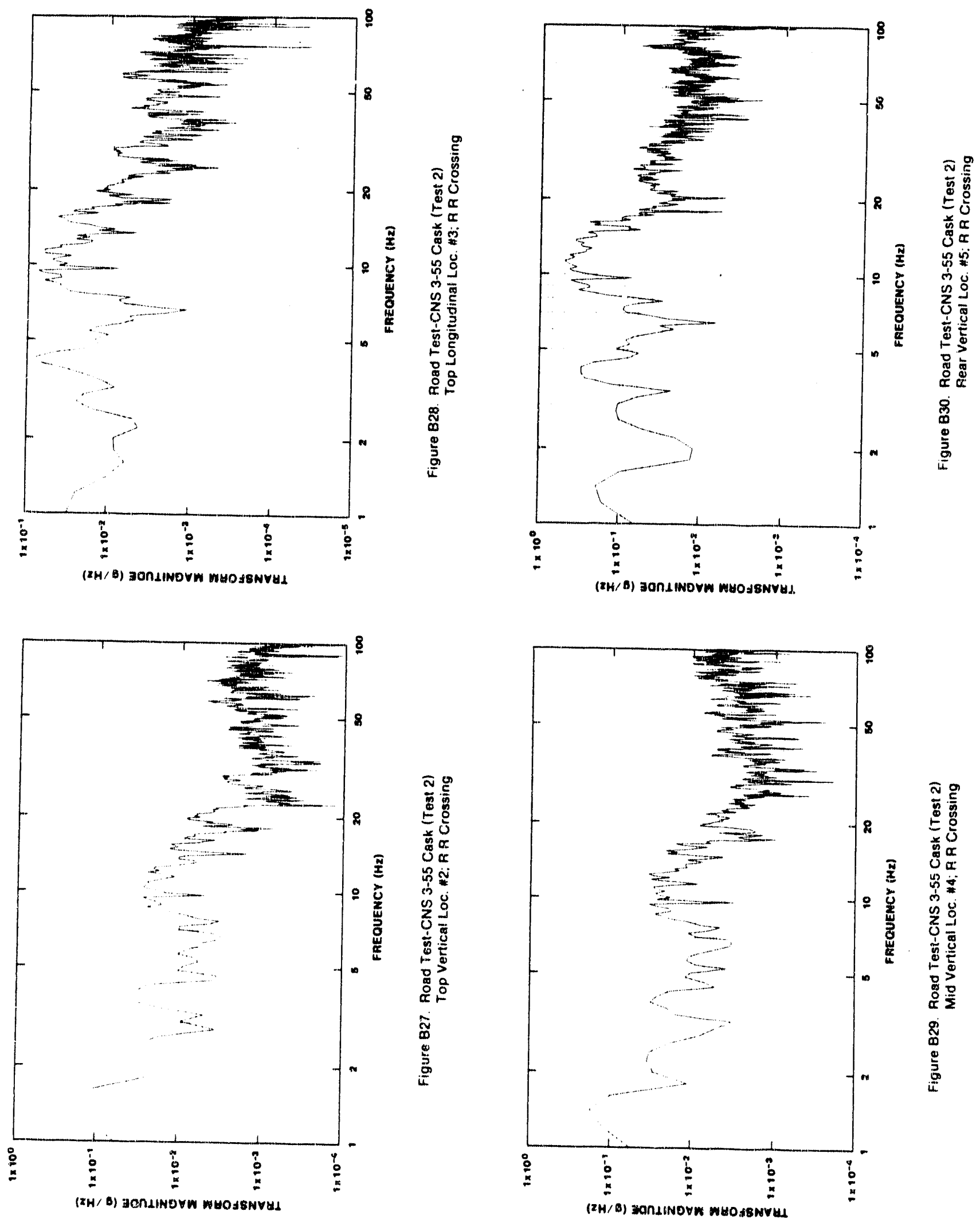


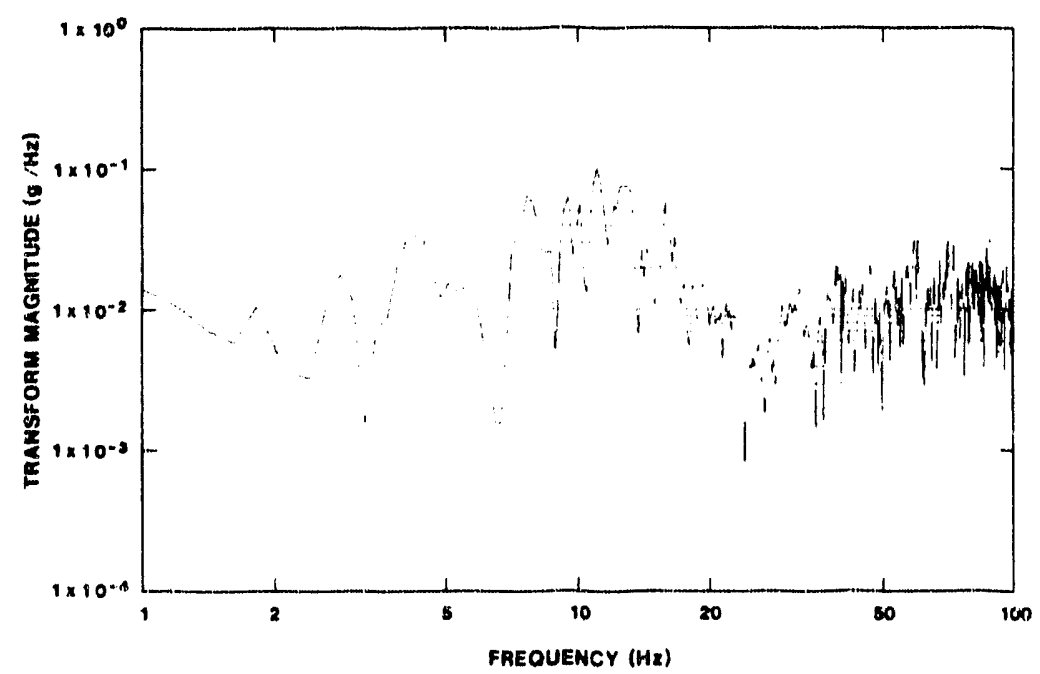

Figure B31. Rood Test-CNS 3-55 Cask (Test 2) Rear Longitudinal Loc. *6; A R Crossing

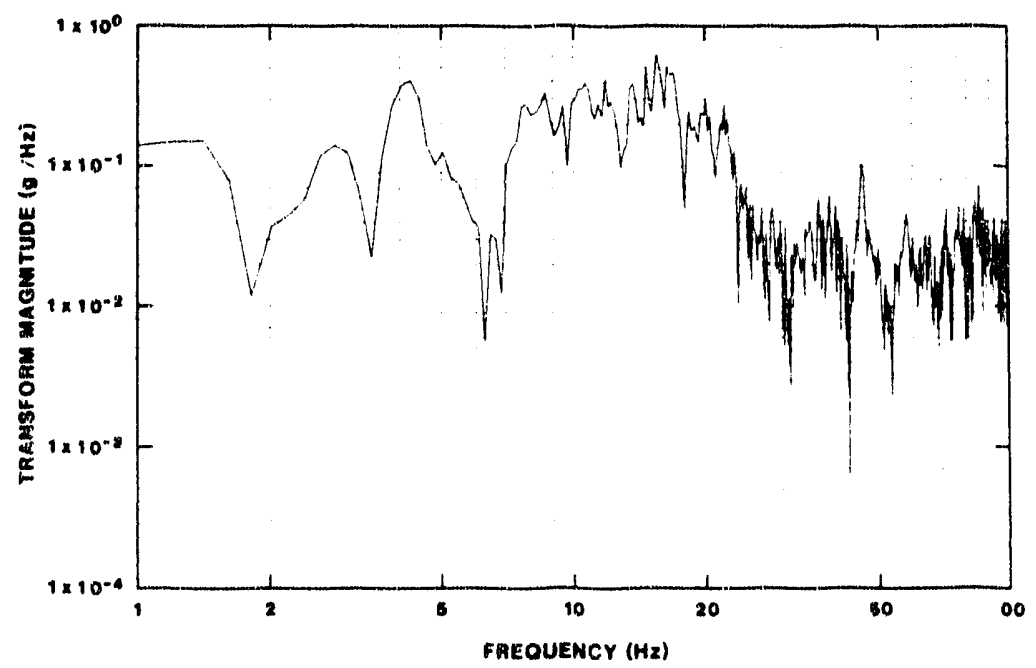

Figure B32. Road Test-CNS 3-55 Cask (Test 2)

Front Vertical Loc \#7; R R Crossing 


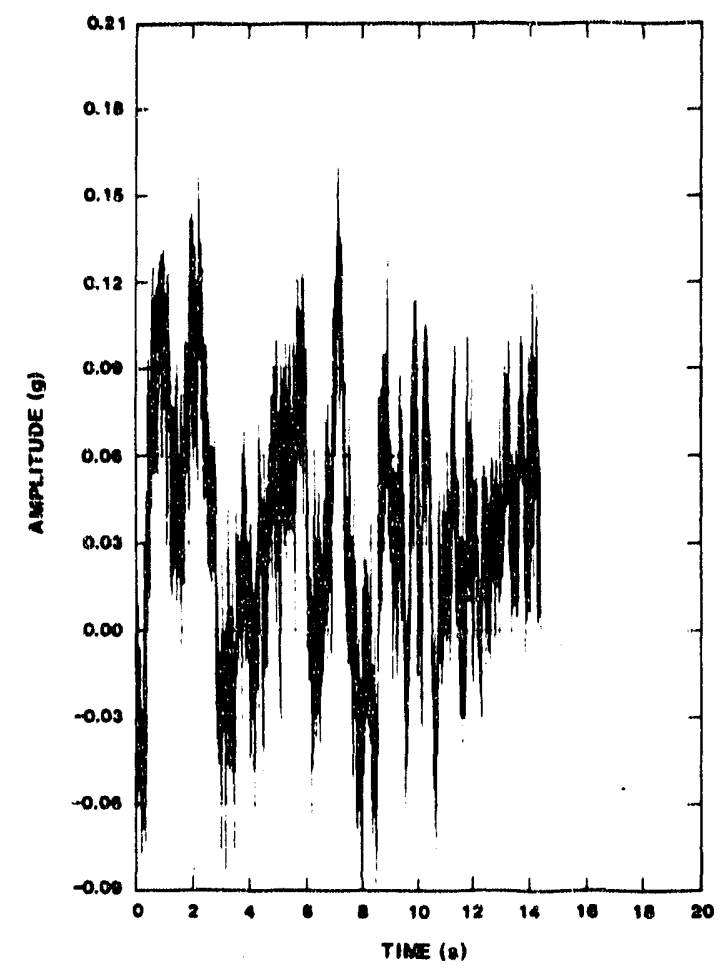

Figure B33. Foad Test-CNS 3-55 Casik (Test 2) Top Transverse Loc. 1 ; Rough Asphalt

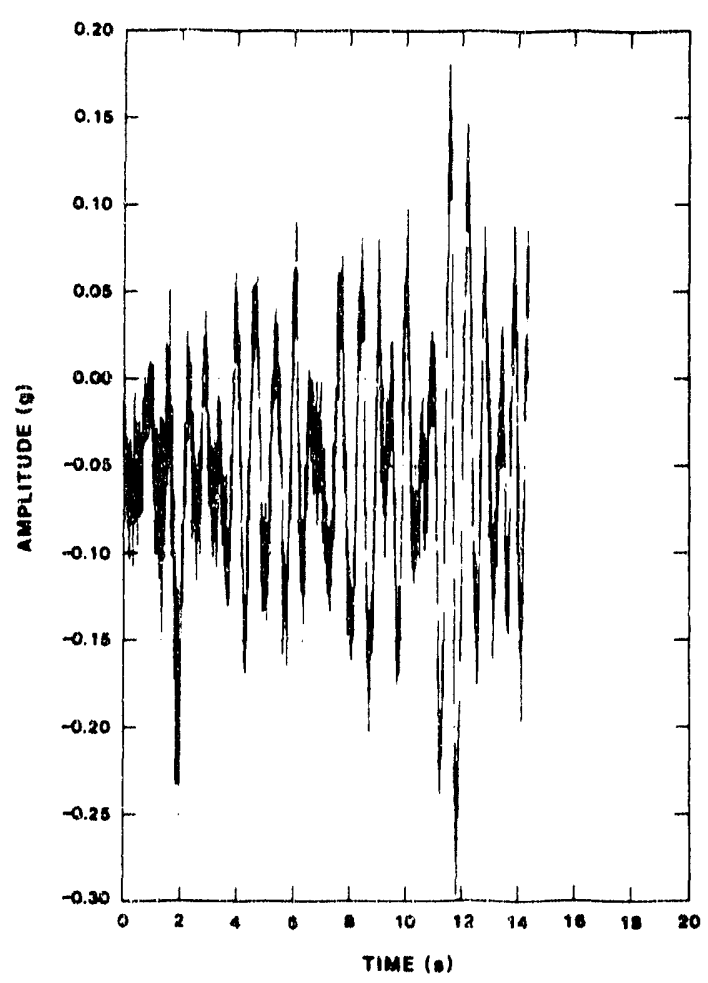

Figure B35. Road Test-CNS 3-55 Cask (Test 2) TOP Vertical LoC. 2; Rough Asphalt

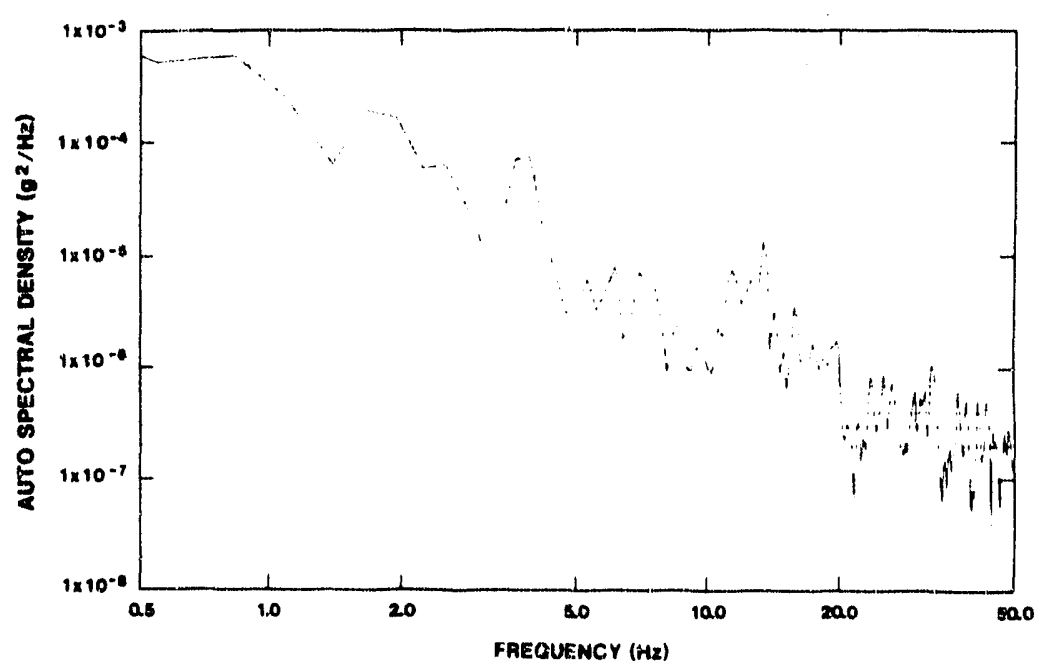

Figure B34, Road Test-CNS 3-55 Cask (Test 2)

Top Transverse Loc. 1; Rough Asphalt

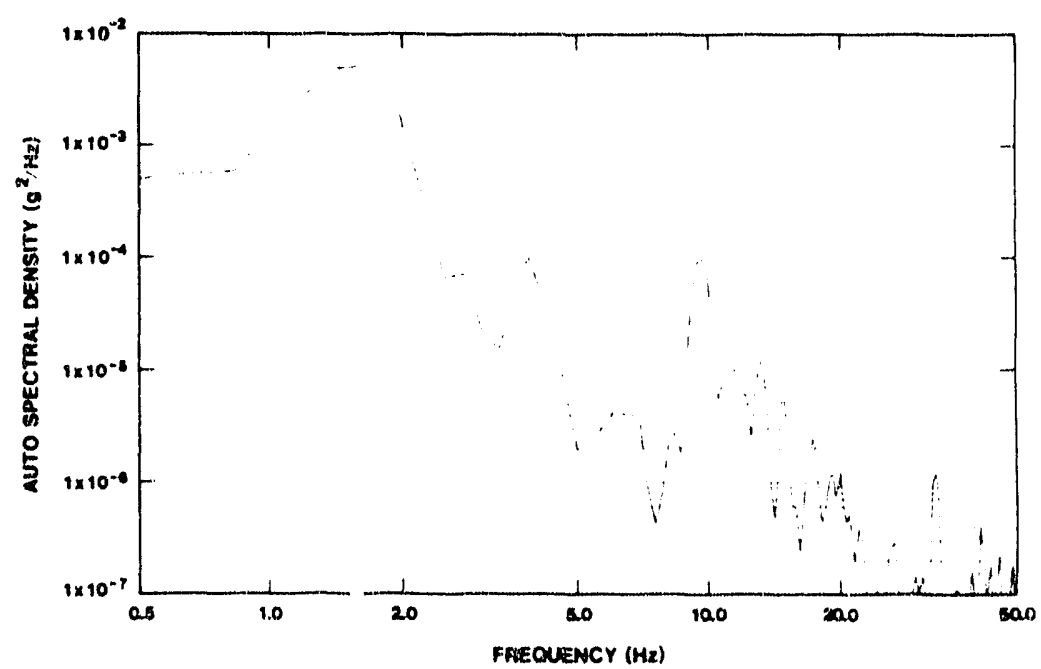

Figure B36. Road Test-CNS 3-55 Cask (Test 2) YOP Vertical LOC. A2; Rough Asphalt 


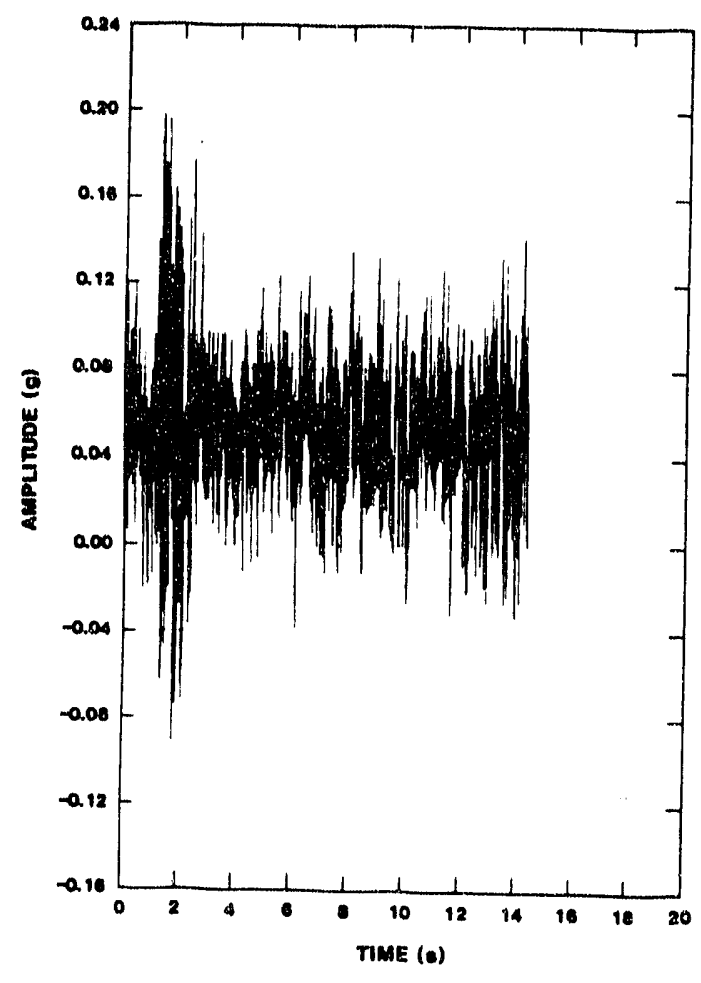

Figure B37. Road Test-CNS 3-55 Cask (Test 2) Top Longitudinal Loc. \#3; Rough Asphalt

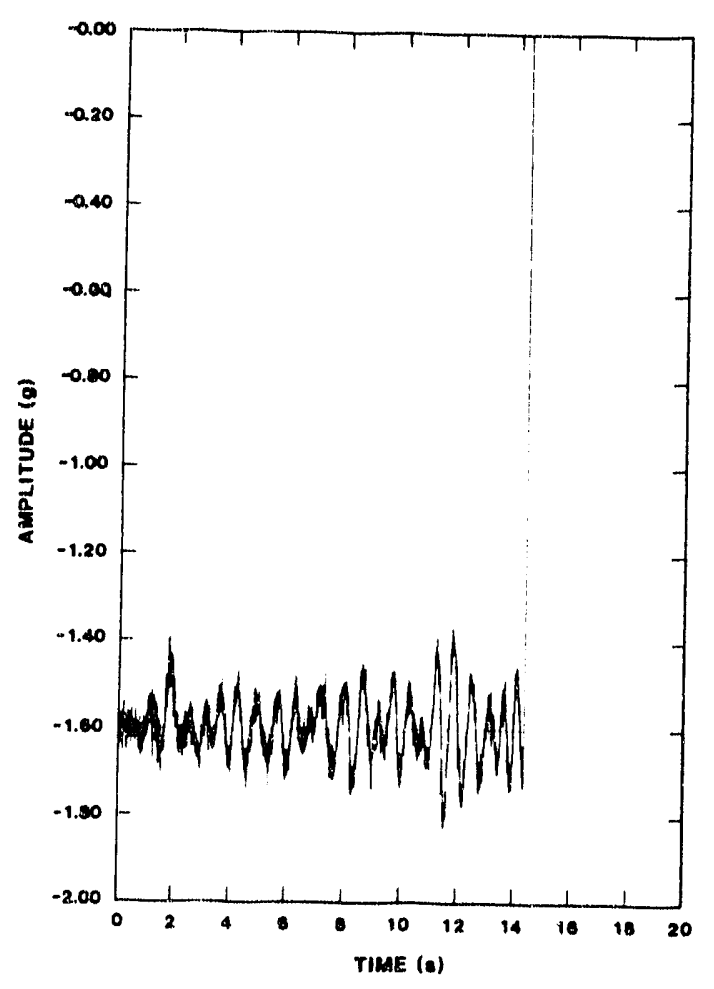

Figure 839. Road Test-CNS 3-55 Cask (Test 2) Mid Vertical Loc. "4; Rough Asphalt

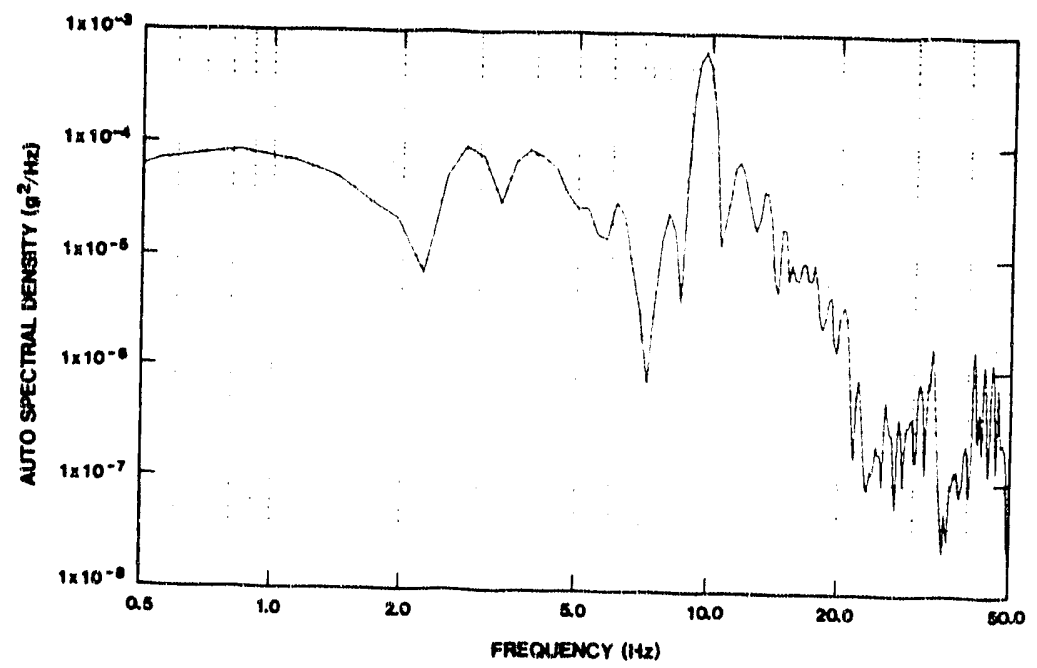

Figure B38. Road Test-CNS 3-55 Cask (Test 2) Top Longitudinal LoC. 3 ; Rough Asphalt

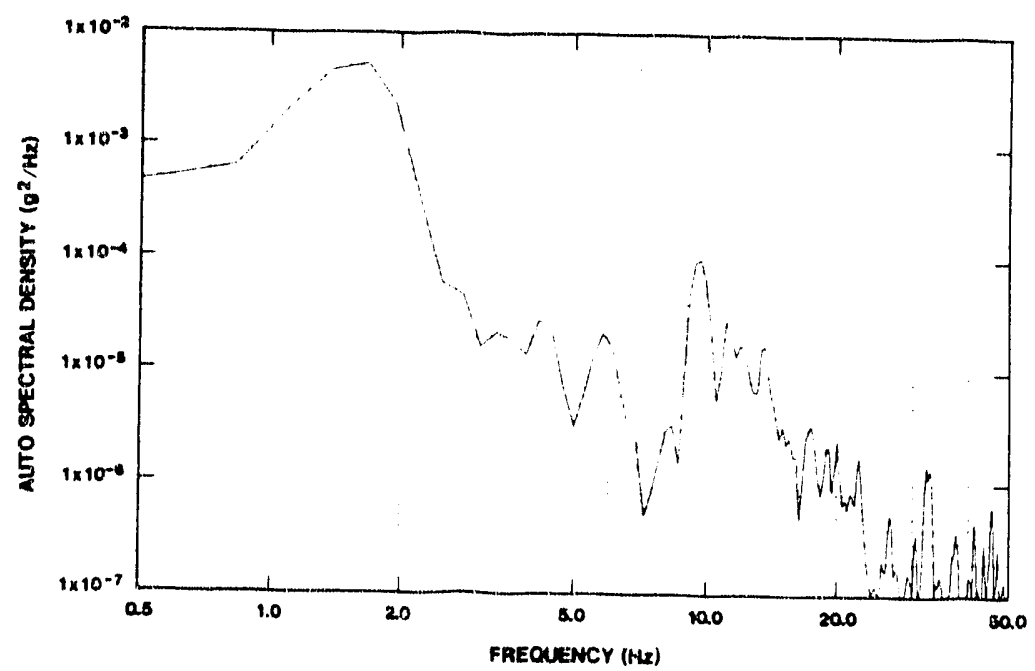

Figure B40. Ro8d Test-CNS 3-55 Cask (Test 2) Mid Vertical LoC. "4; Rough Asphalt 


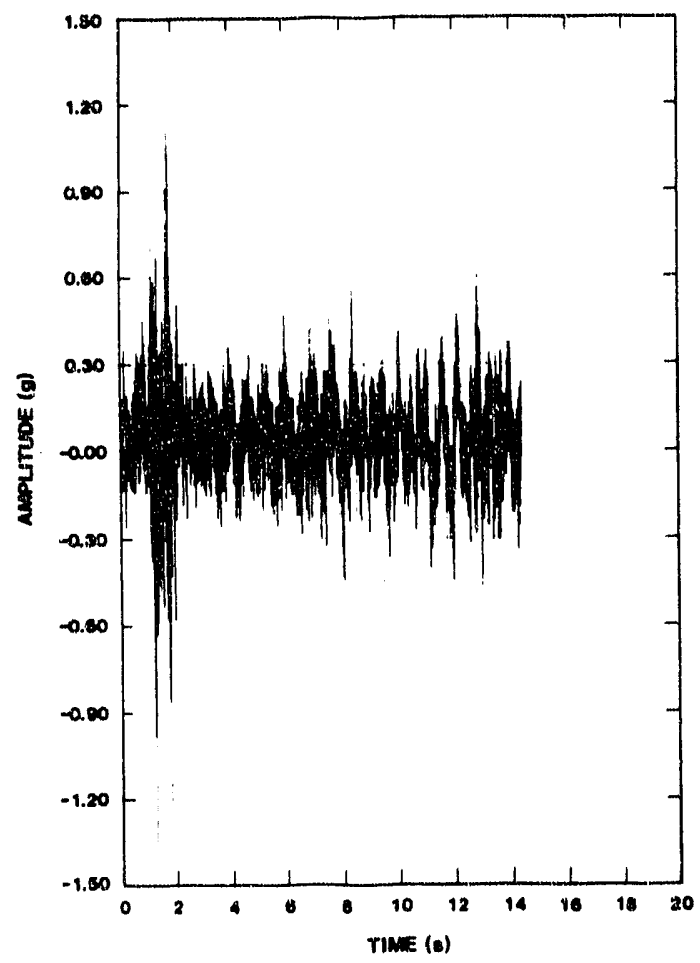

Figure B41. Road Test-CNS 3-55 Cask (Test 2) Rear Vertical Loc. \#5; Rough Asphalt

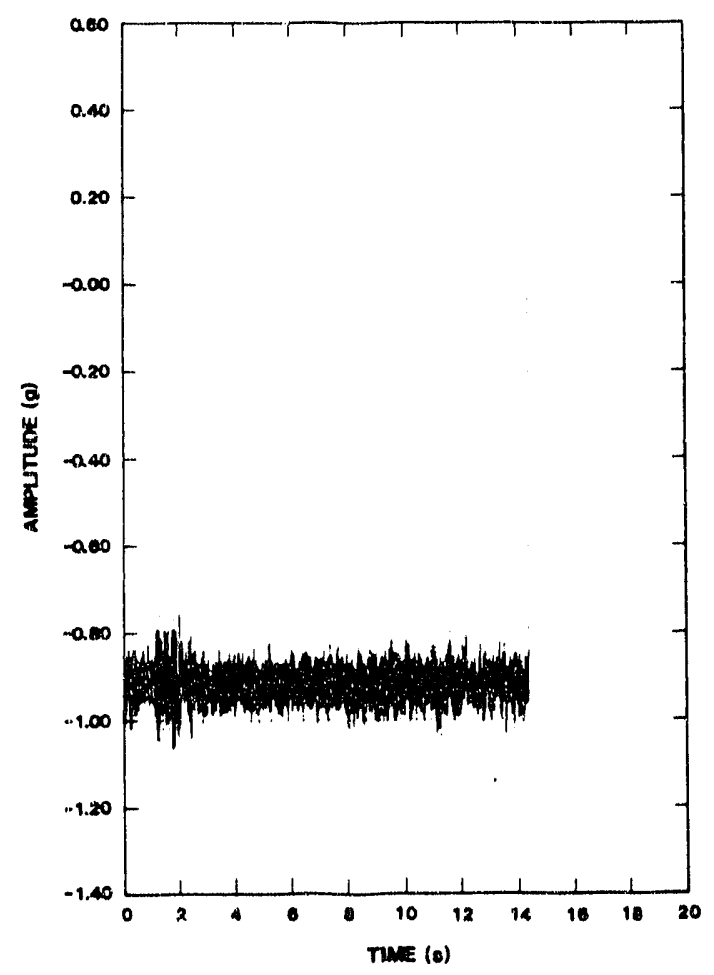

Figure B43. Foad Test-CNS 3-55 Cask (Test 2) Rear Longitudinal Loc. 6 ; Rough Asphalt

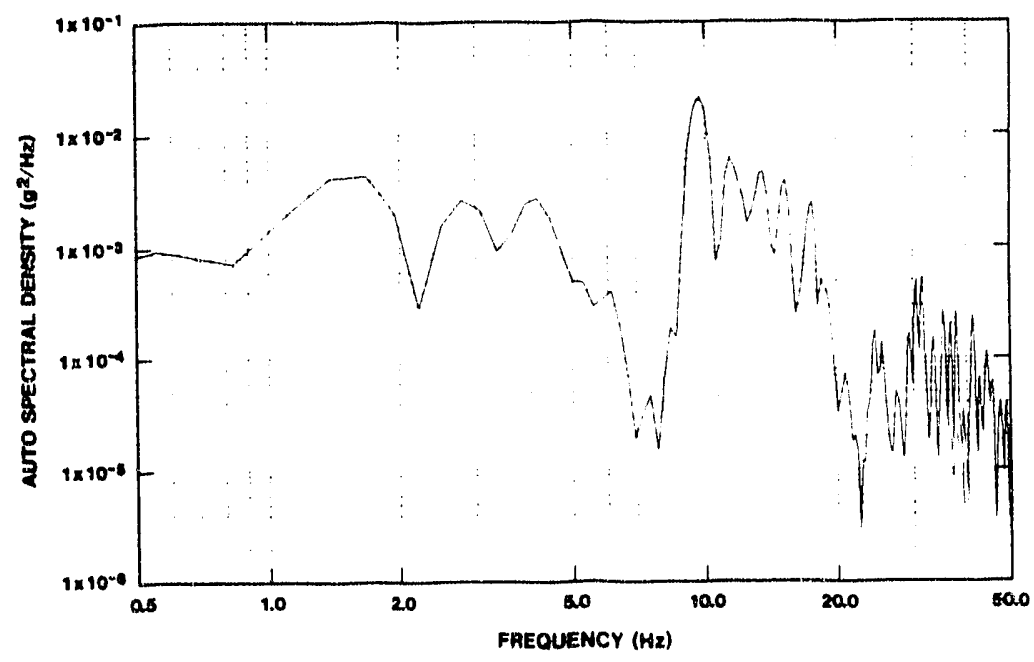

Figure B42. Road Test-CNS 3-55 Cask (Test 2) Roar Vertical Loc. \#5; Rough Asphalt

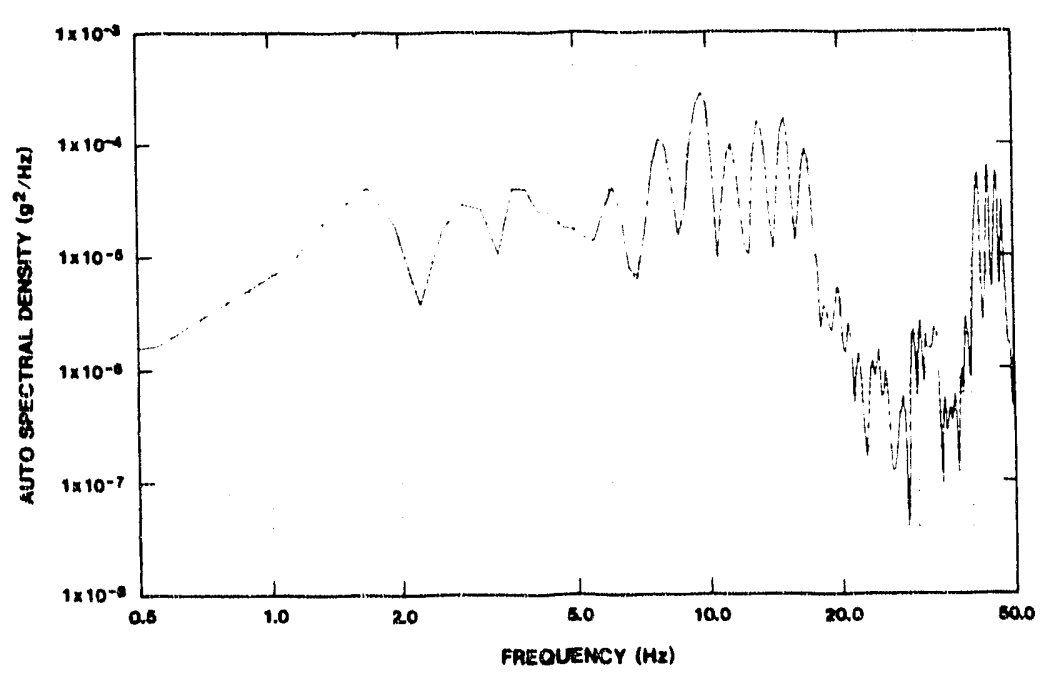

Figure B44. Road Test-CNS 3-55 Cask (Tost 2) Rear Longitudinal Loc. "6; Rough Asphalt 


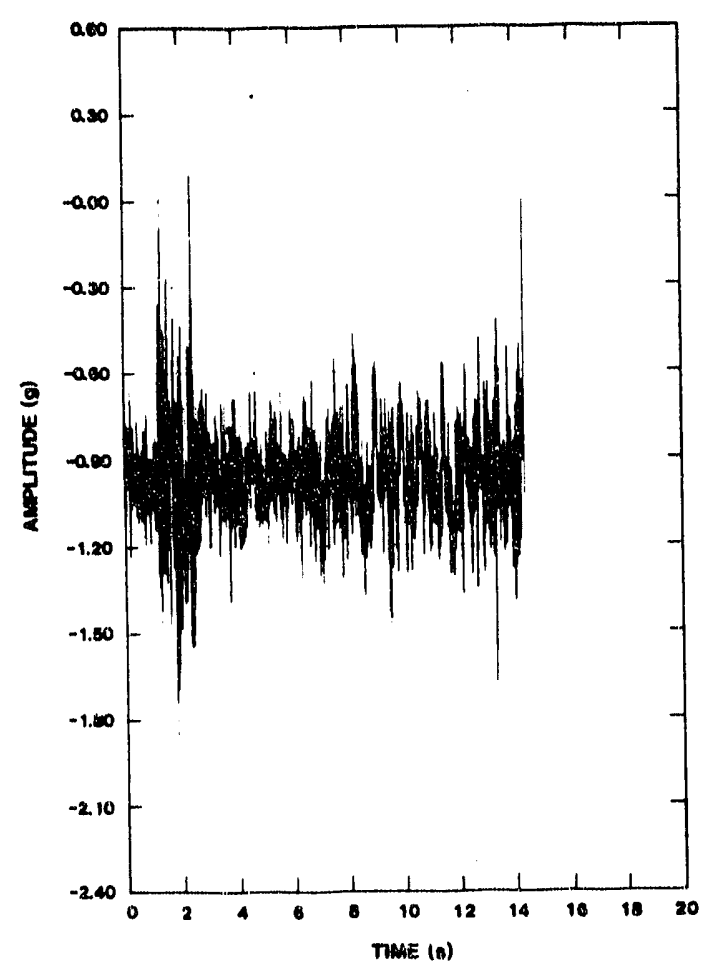

Figure B45. Road Tost-CNS 3-55 Cask (Test 2) Front Vertical Loc. \#7; Rough Asphalt

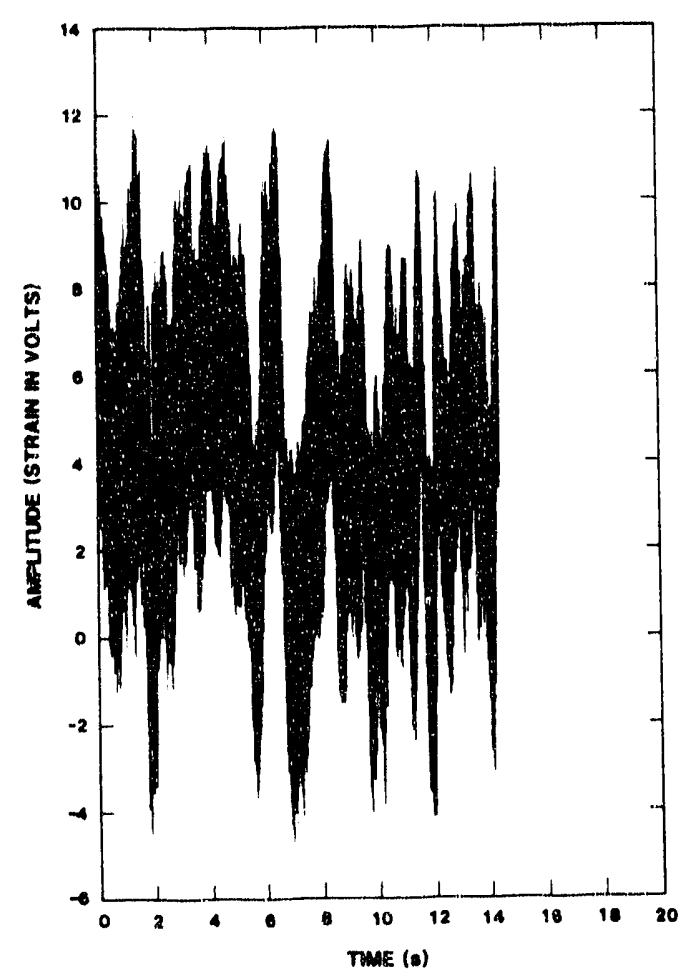

figure B47. Road Test-C̄NS $3-55$ Cask (Test 2) Front Strain Gage Loc. *13; Rough Asphait

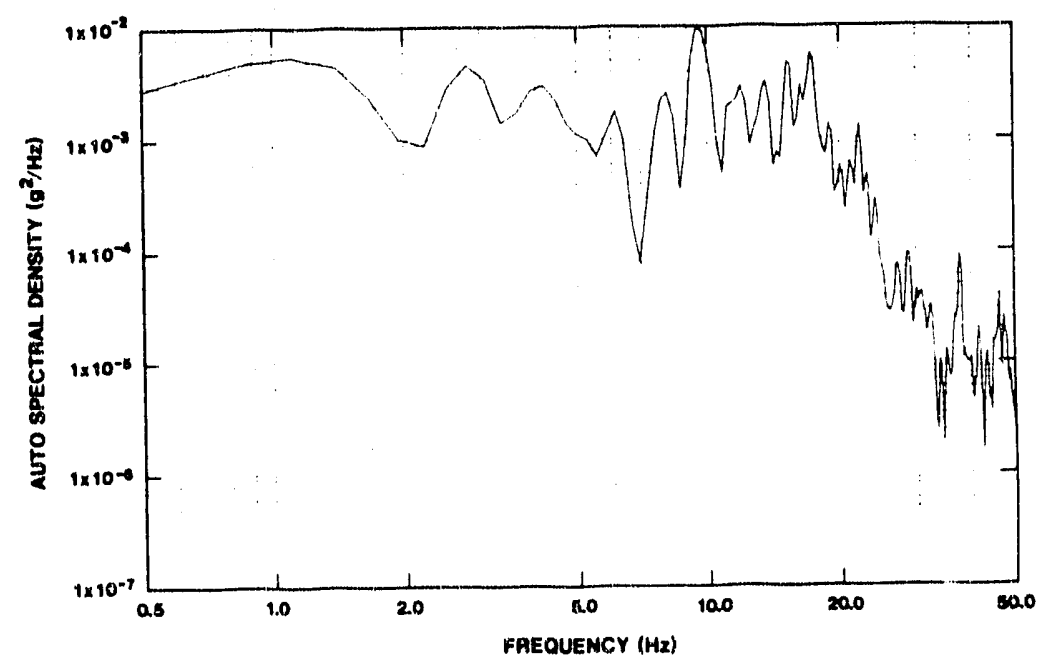

Figure B46. Road Test-CNS 3-55 Cask (Test 2) Front Vertical Loc. 17; Rough Asphalt

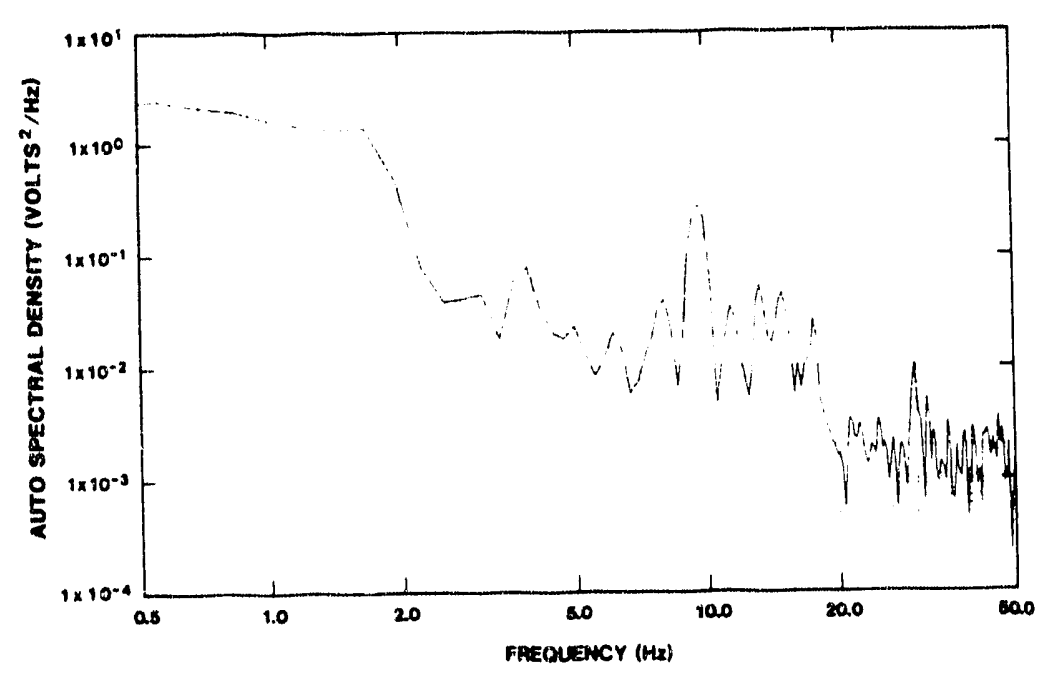

Figure 848. Road Test-CNS 3-55 Cask (Test 2) Front Strain Gage LoC. 13; Rough Asphalt 


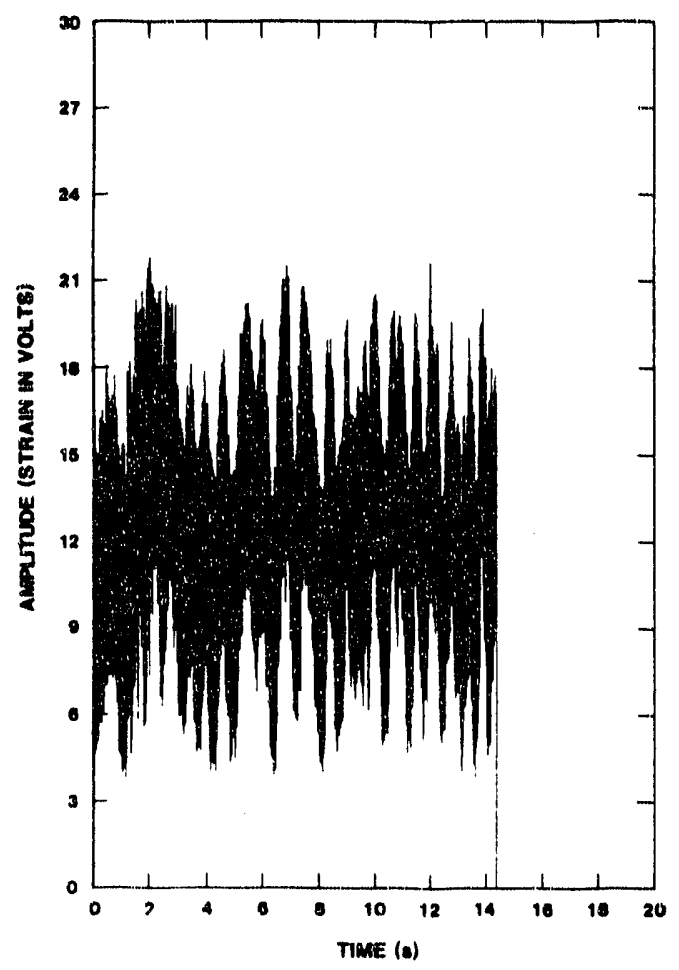

Figure B49. Road Test-CNS 3-55 Cask (Tesi 2) Rear Strain Gage Loc. H14; Rough Asphalt

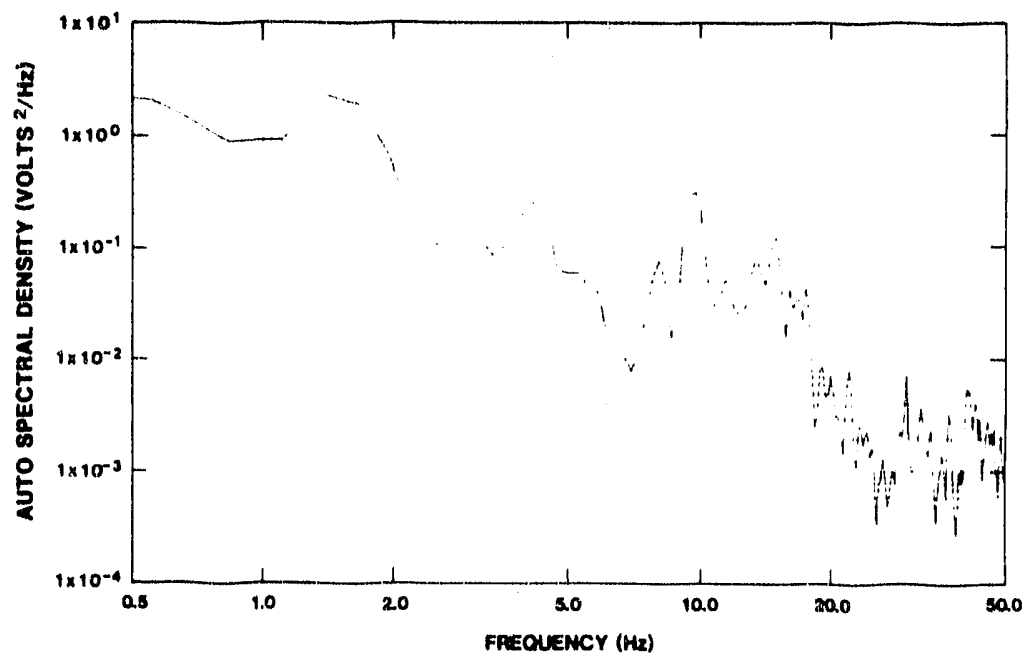

Figure B50. Road Test-CNS 3-55 Cask (Test 2) Rear Strain Gage Loc. \#14; Rough Asphalt 

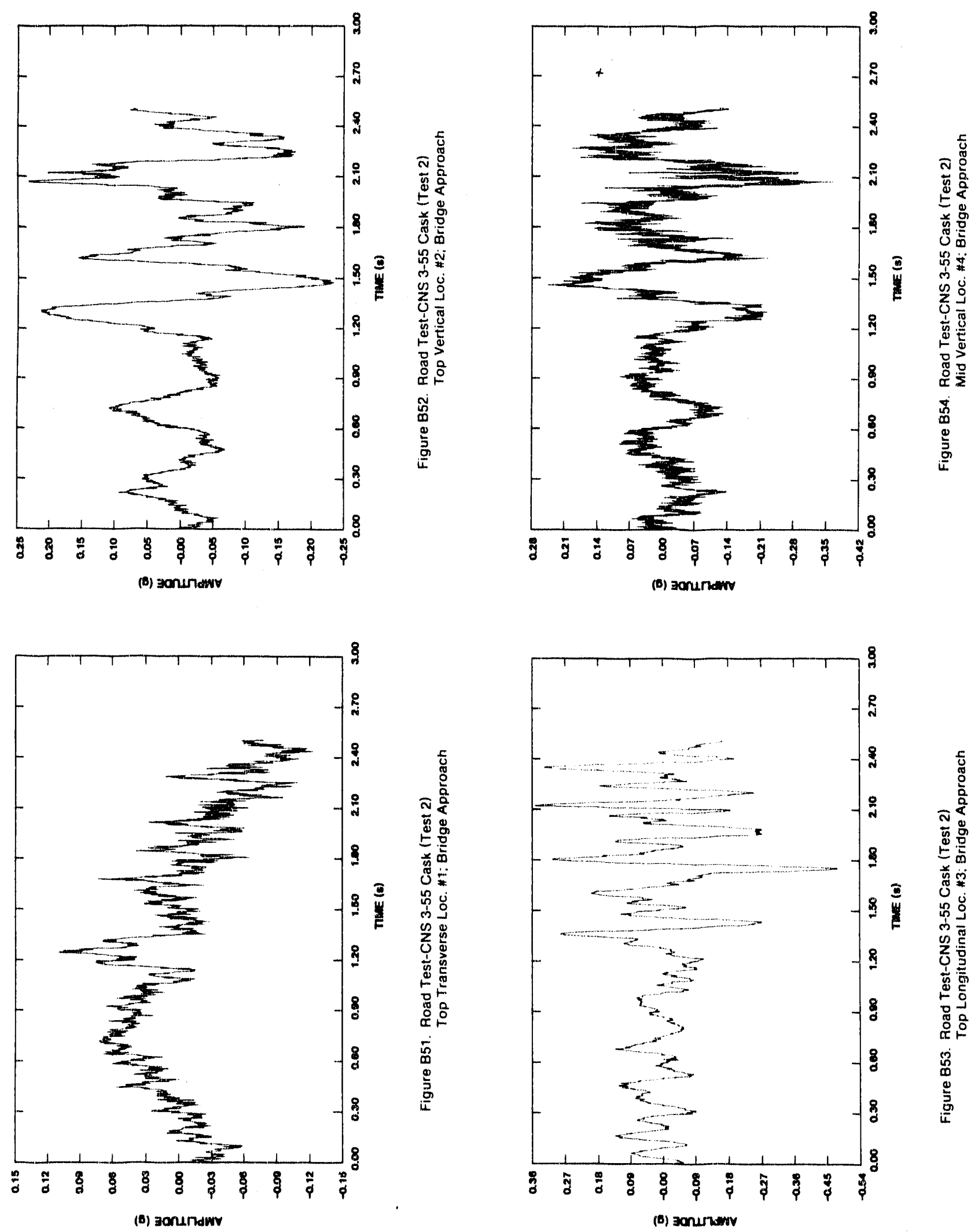

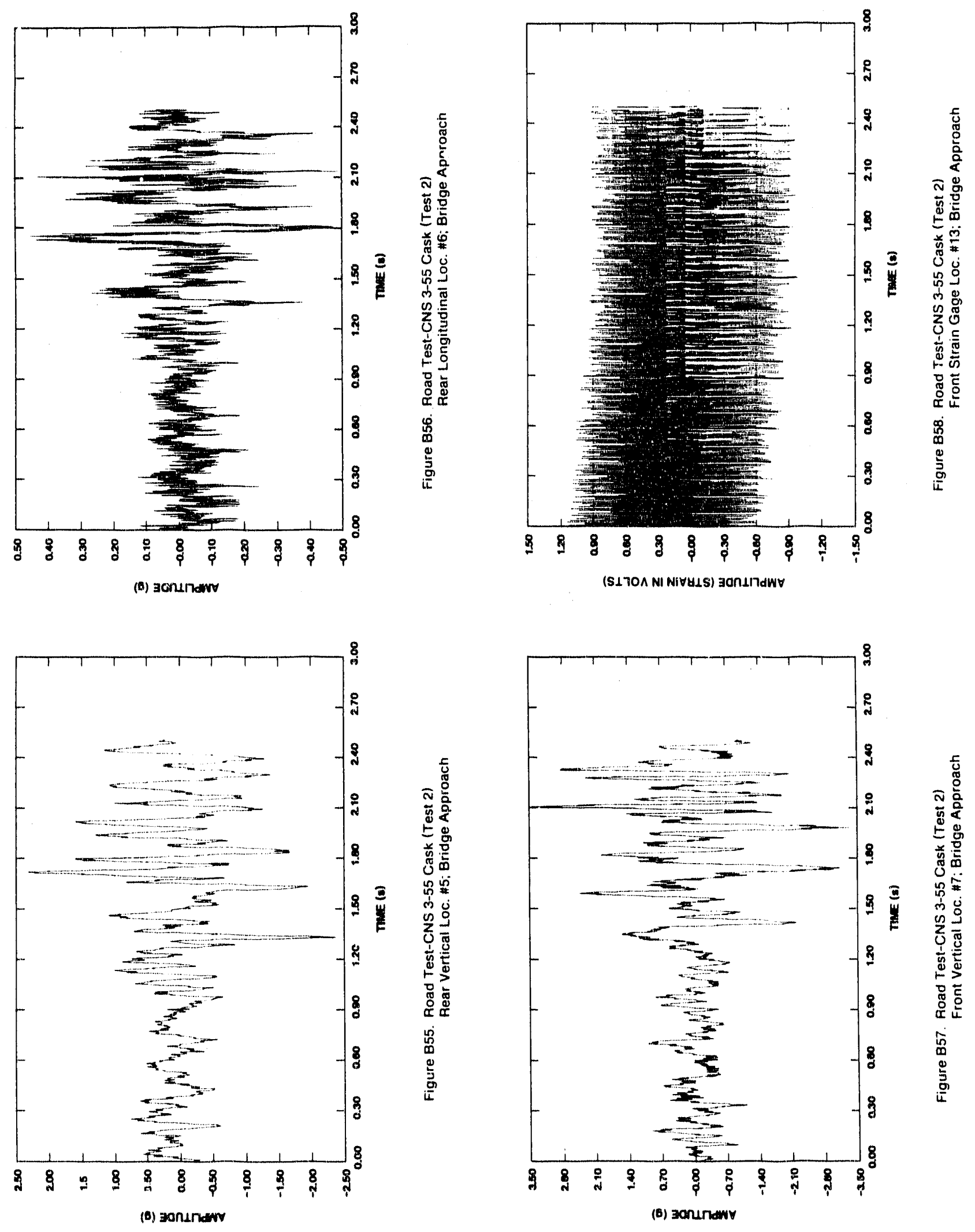


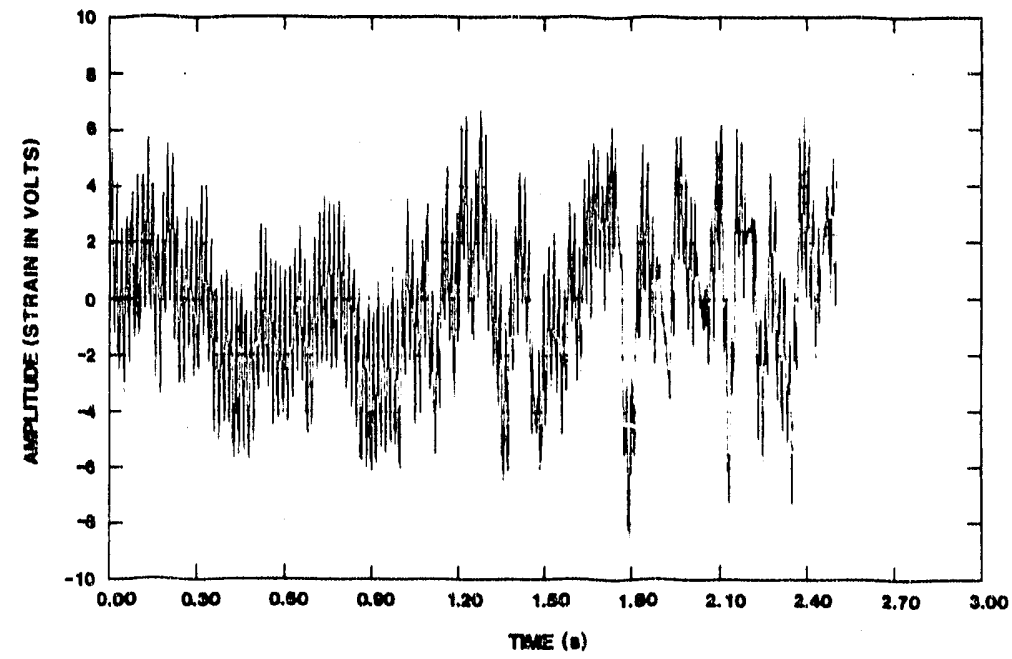

Figure B59. Road Test-CNS 3-55 Cask (Test 2)

Rear Strain Gage Loc. \#14; Bridge Approach 


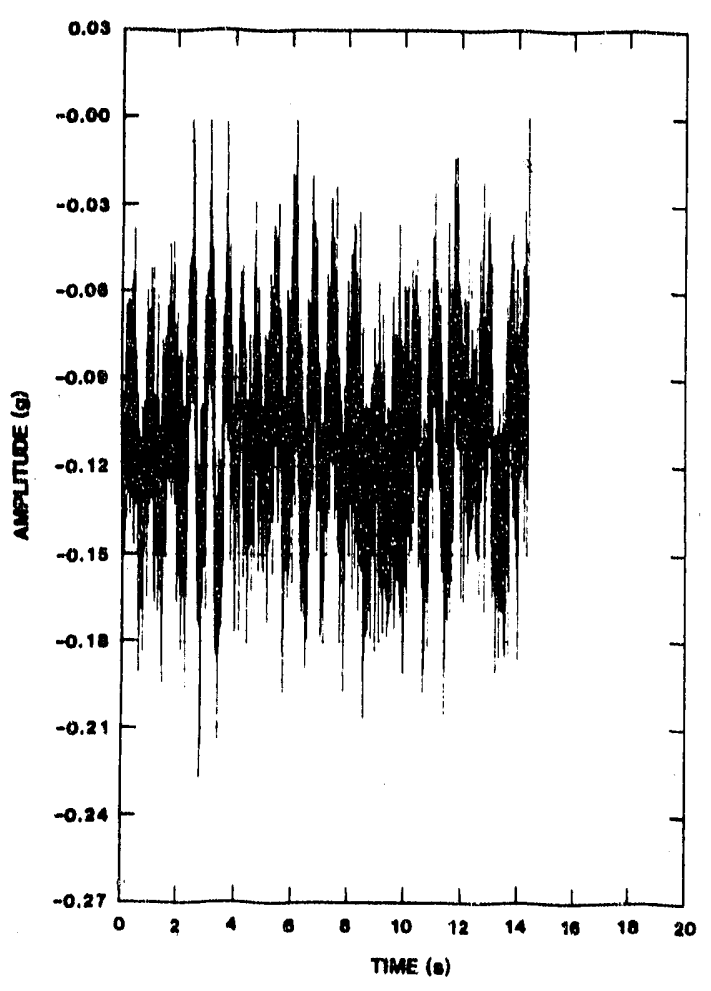

Figure B60. Road Test-CNS 3-55 Cask (Test 2) Top Vertical Loc. \#2; Rough Concrete

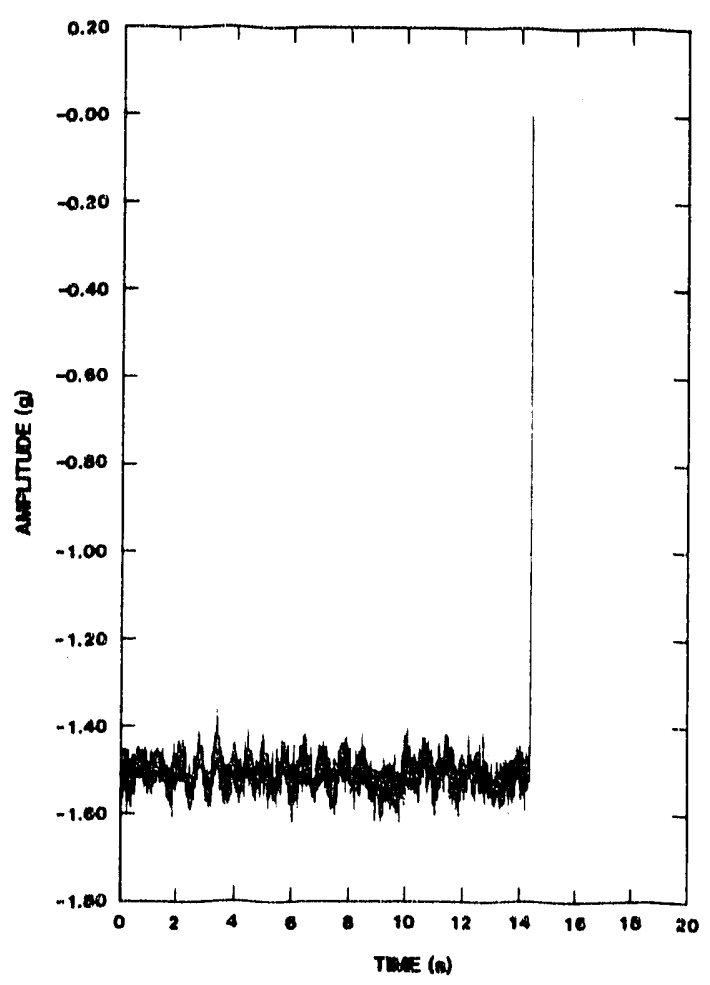

Figure B62. Poad Test-CNS 3-55 Cask (Test 2) Mid Vertical Loc. "4; Rough Concrete

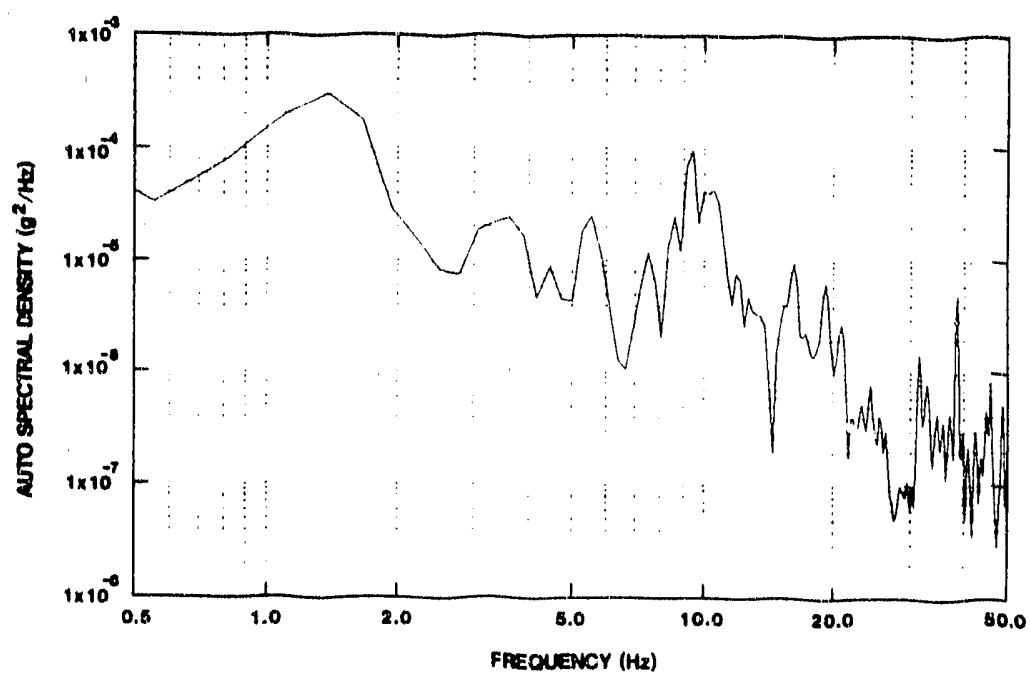

Figure 861. Road Test-CNS 3-55 Cask (Test 2) Top Vertical Loc. \#2; Rough Concreto

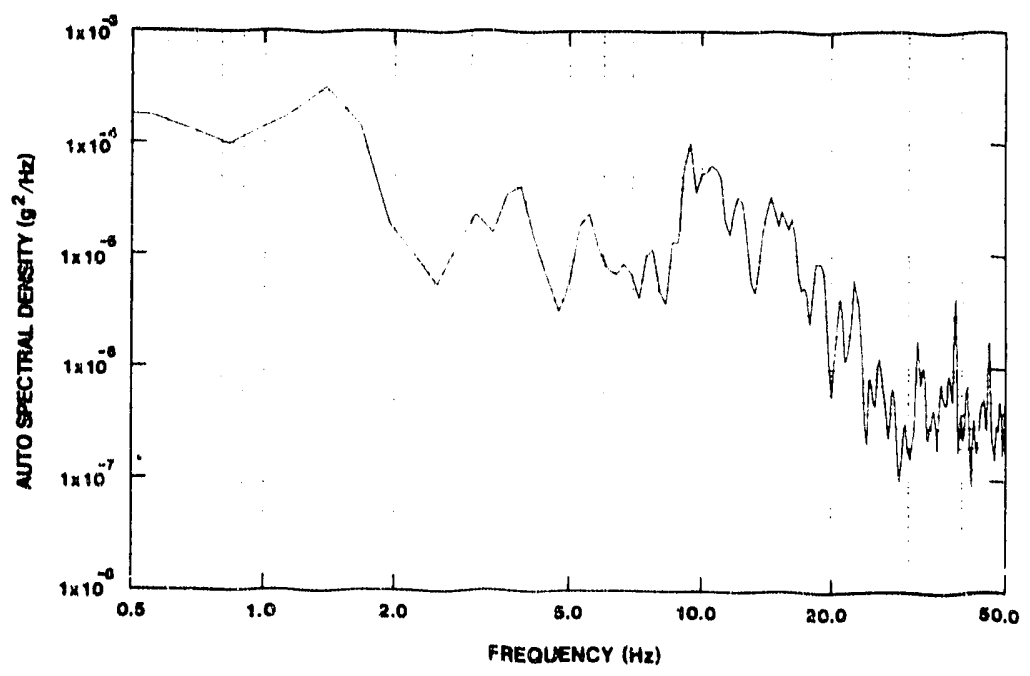

Figure B63. Road Test-CNS 3-55 Cask (Test 2) Mid Vertical Loc. \#4; Rough Concrete 


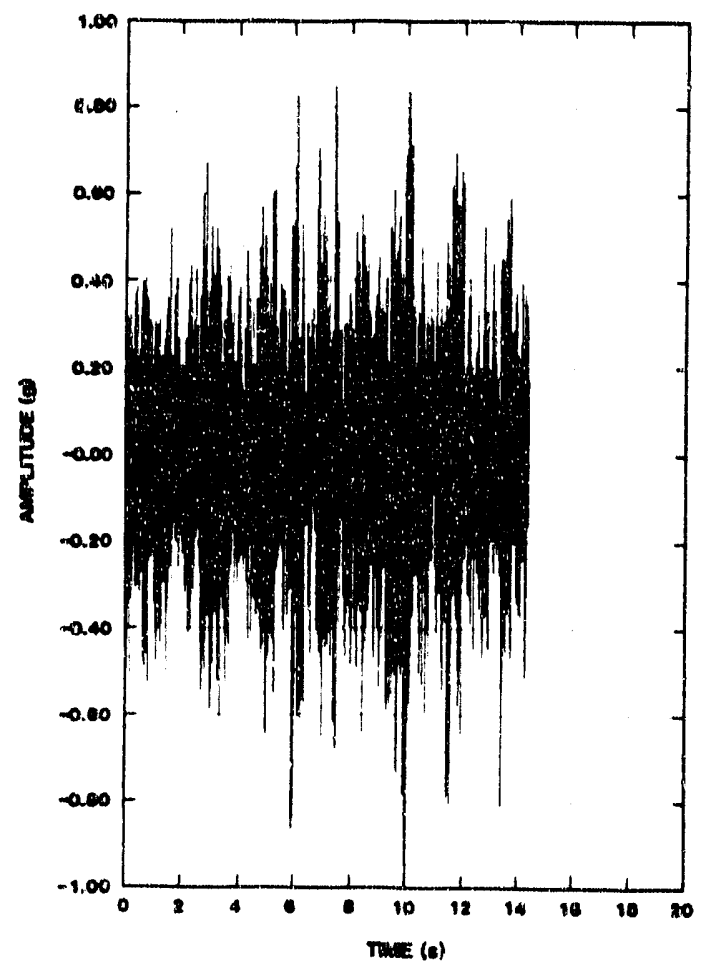

Figure B64. Road Test-CNS 3-55 Cask (Test 2) Rear Vertical Loc. \#5; Rough Concrete

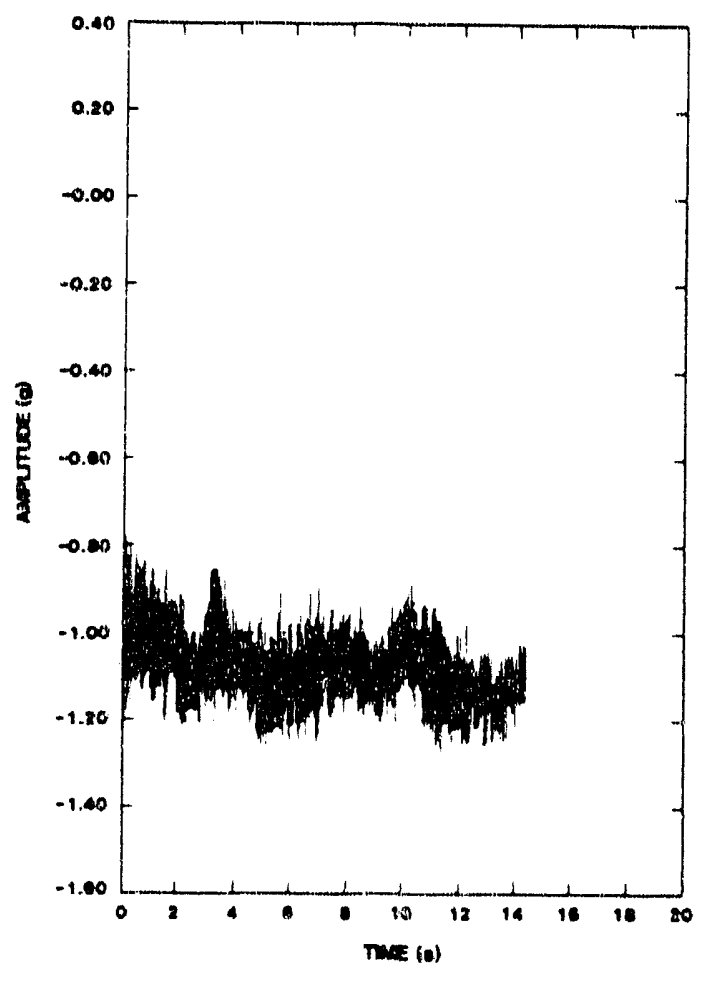

Figure B66. Road Tasi-CNS 3.55 Cask (Test 2) Rear Longitusinal LoC 6. Rough Cons,rete

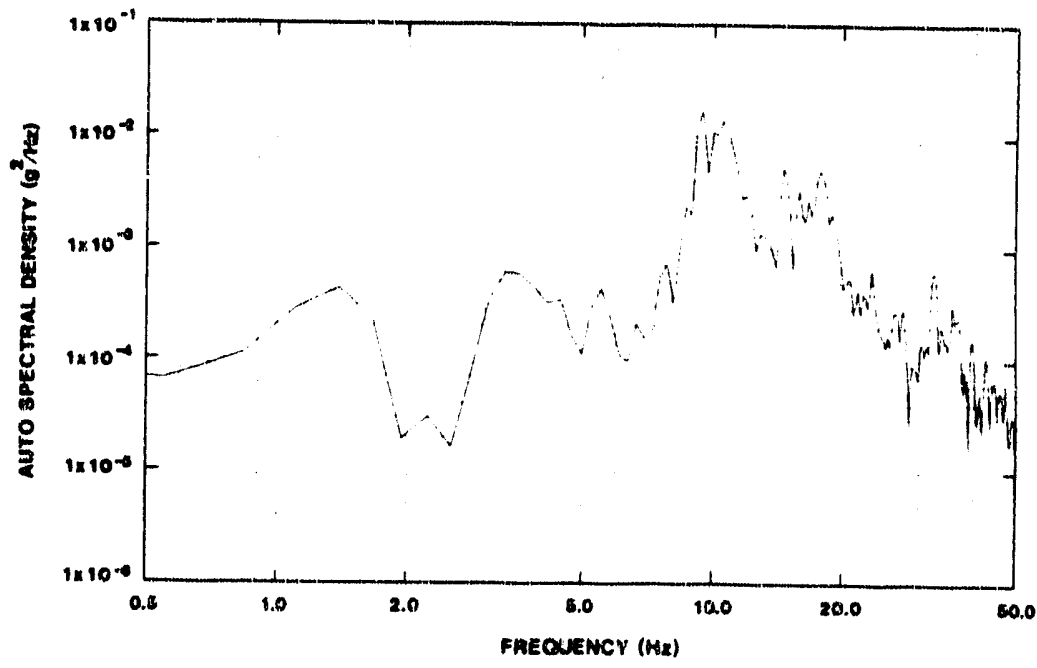

Figure 865. Road Test-CNS 3-55 Cask (Test 2) Rear Vertical Loc. 5 ; Aough Concrate

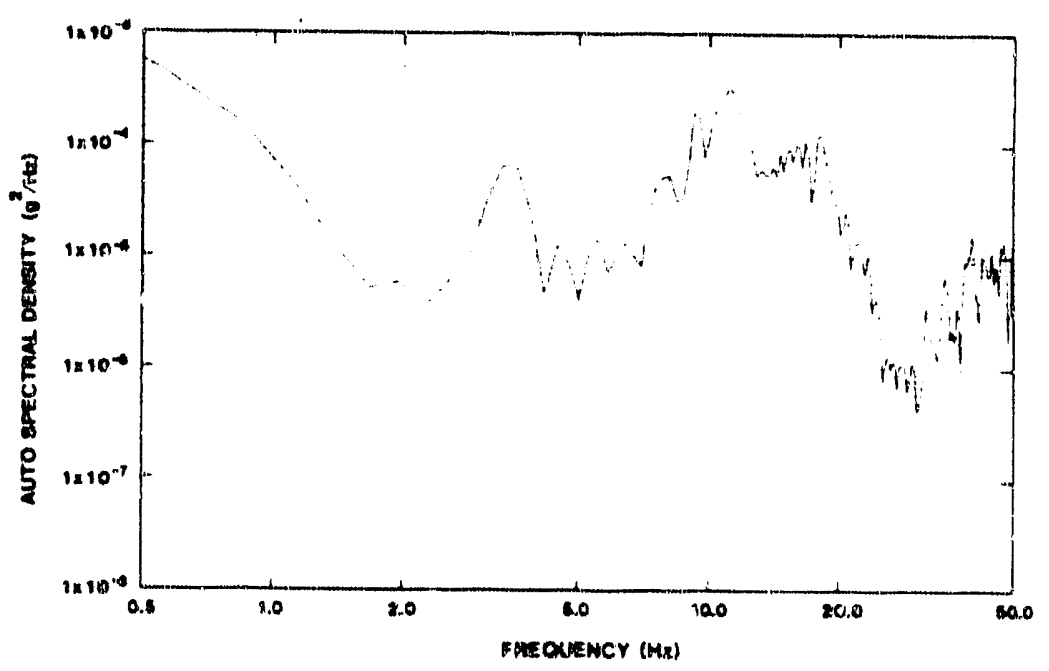

Figure B67. Road Test-CNS 3-55 Cagk (Test 2) Rear Longitudinal Loc 6 ; RC gh Cancrele 


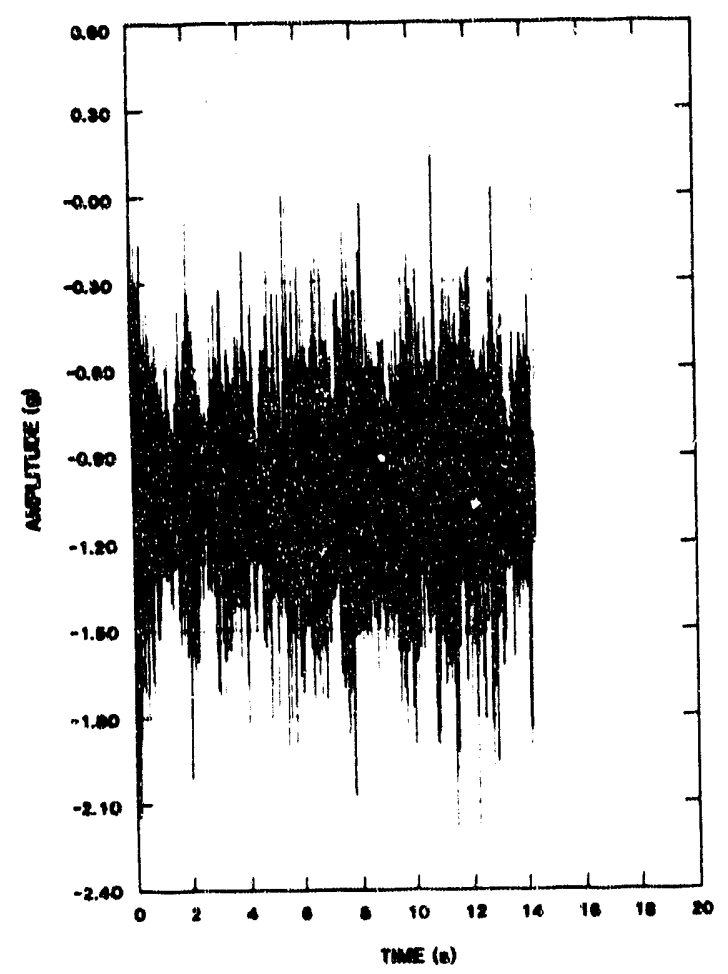

Figure B68. Road Test-CNS 3-55 Cask (Test 2) Front Vertical Loc. "7: Rough Concrete

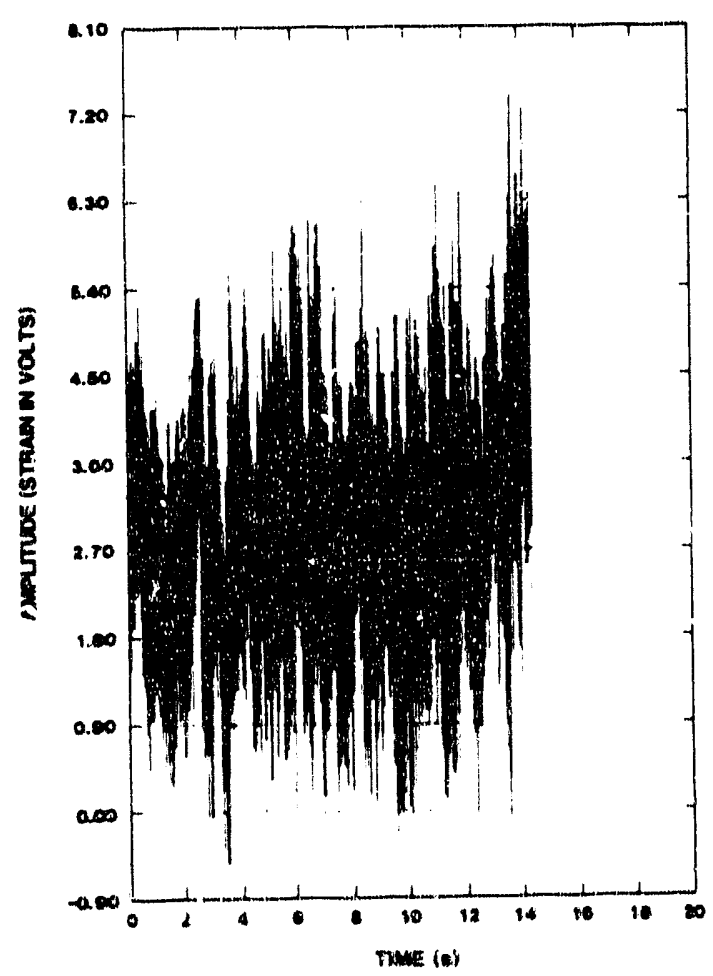

Figure B70 Rond Tesi-CNS 3-55 Cask (Test 2) Front Strain Gage Loc a13; Rough Concrate

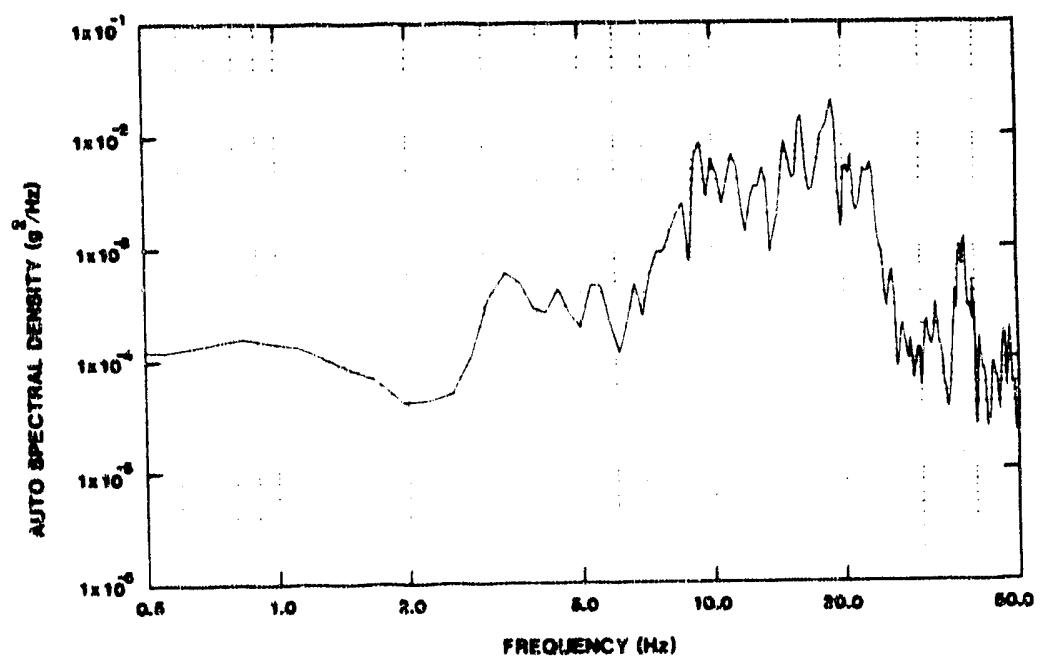

Figure B68. Road Tesi-CNS 3-55 Catk (Test 2) Froni Vertical LOC. A7; Rough Concrete

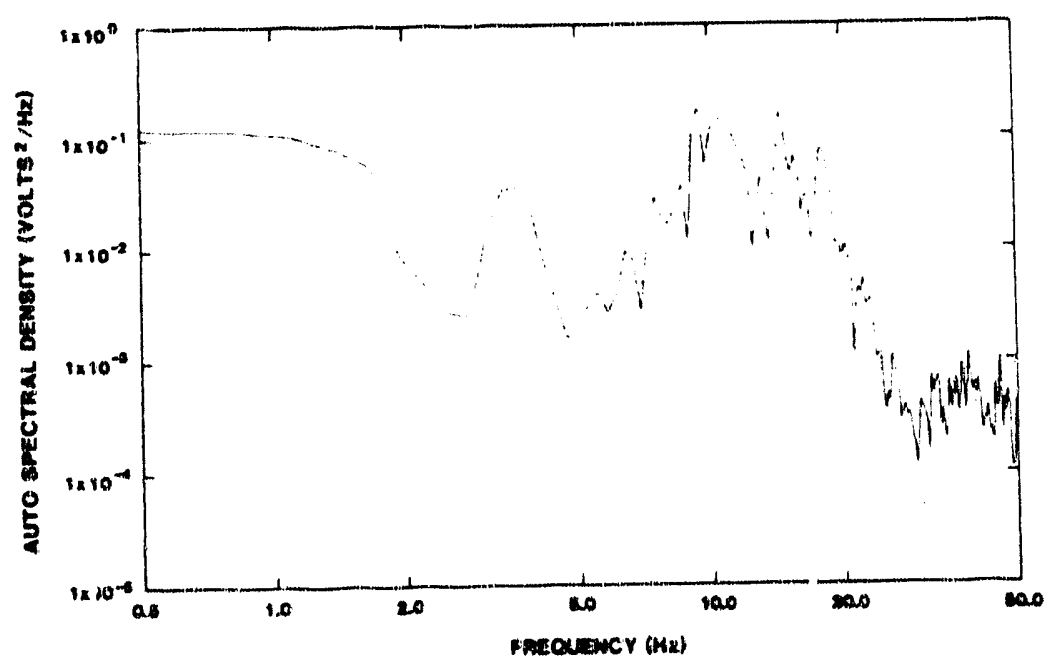

Figure B71 Roud Te8t-CNS 3.55 Cask (Test 2) front Strain Guge Los. "13: Rough Concrete 


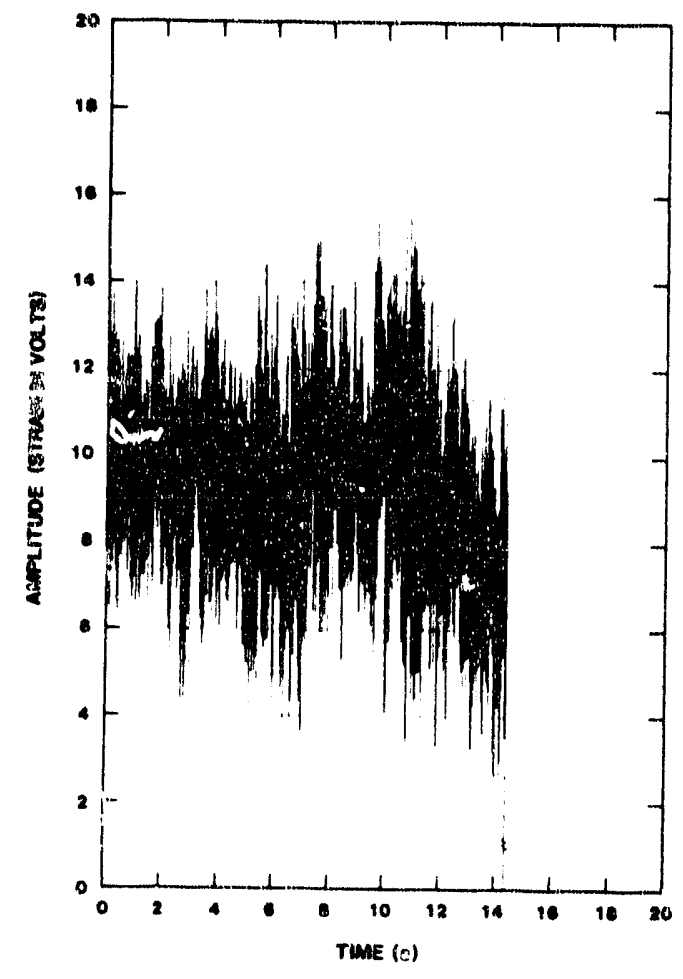

Figure B72. Road Test-CNS 3.55 Cisk (Test 2) Rear Strain Gage LOC. 14: Rough Cuncrete

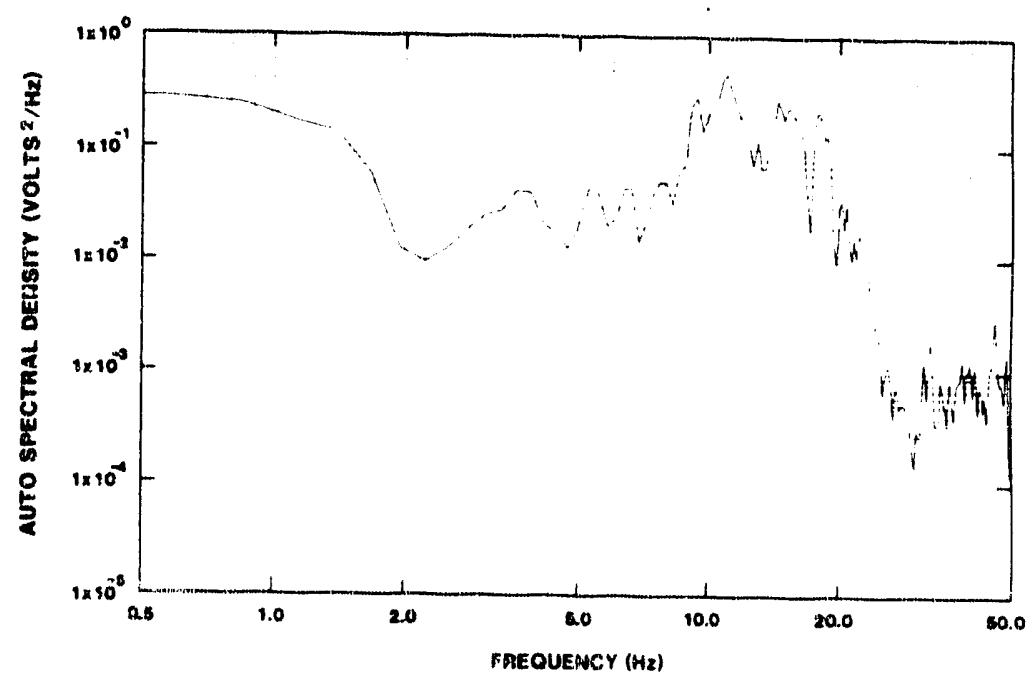

Figure 873. Road Test-CNS 3-55 Cask (Test 2) Rear Strain Gege Lor. 14: Rough Concrete 


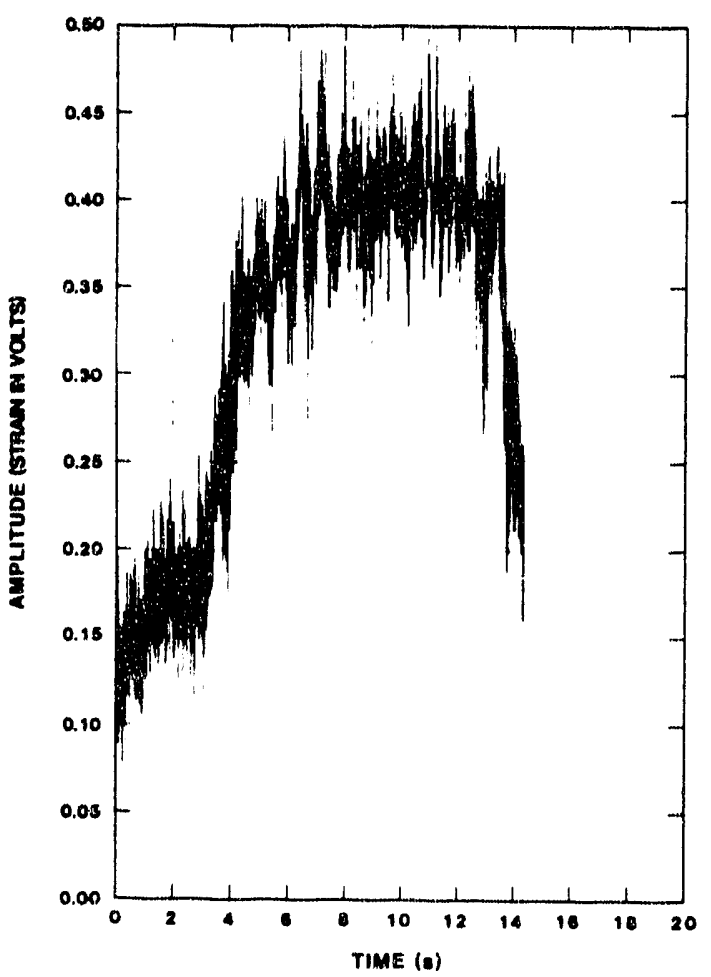

Figure B74. Road Test-CNS 3-55 Cask (Test 2) Top Transverse Loc. 1; Hard R Turn

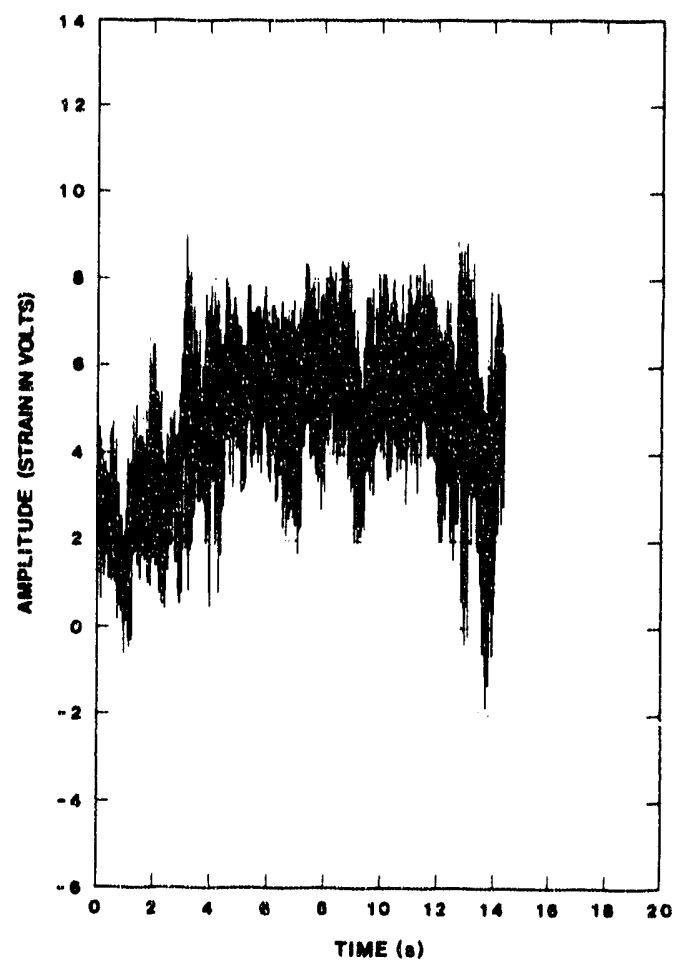

Figure B75. Road Test-CNS 3-55 Cask (Test 2) Front Strain Gage Loc. 13; Hard R Turn

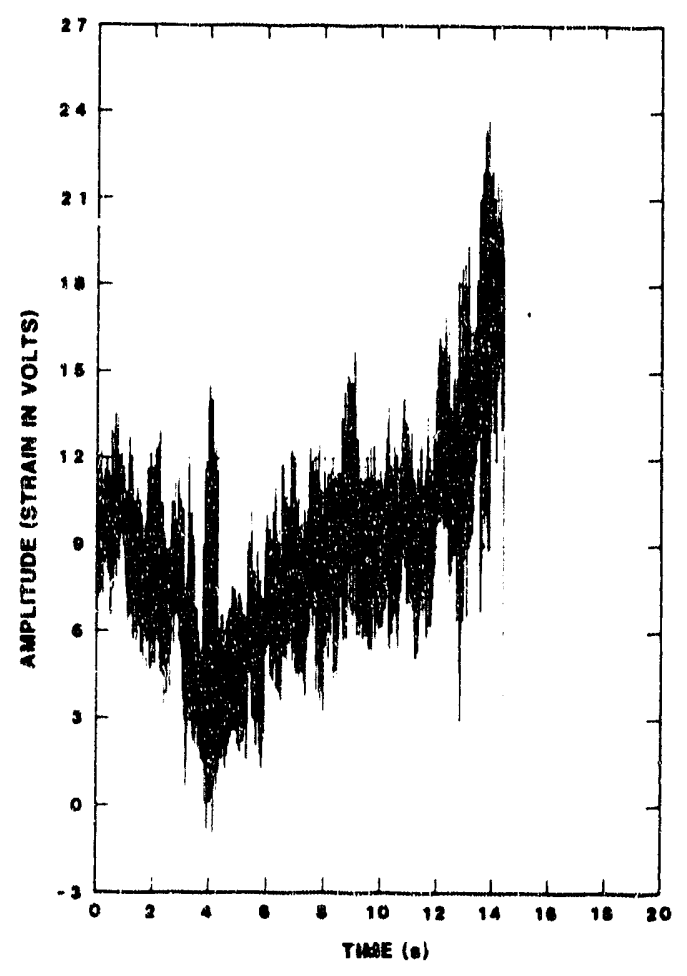

Figure 876. Road Test-CNS 3-55 Cask (Test 2)

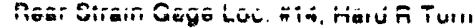




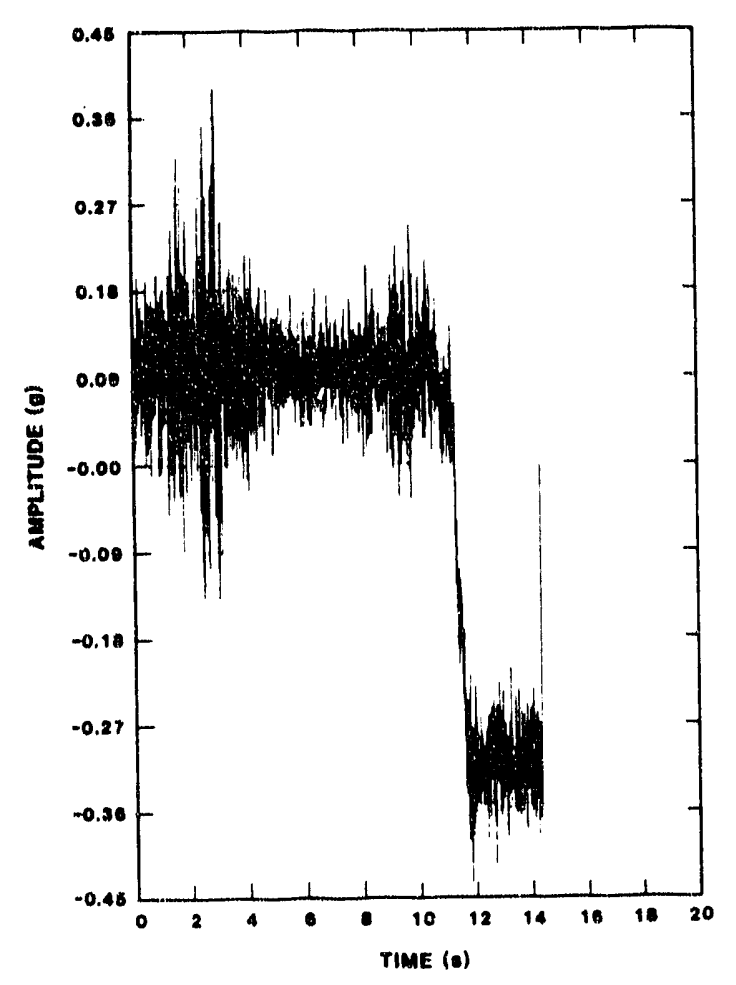

Figure 877. Road Test-CNS 3-55 Cask (Test 2) Top Longitudinal Loc. "3: Hard Stop

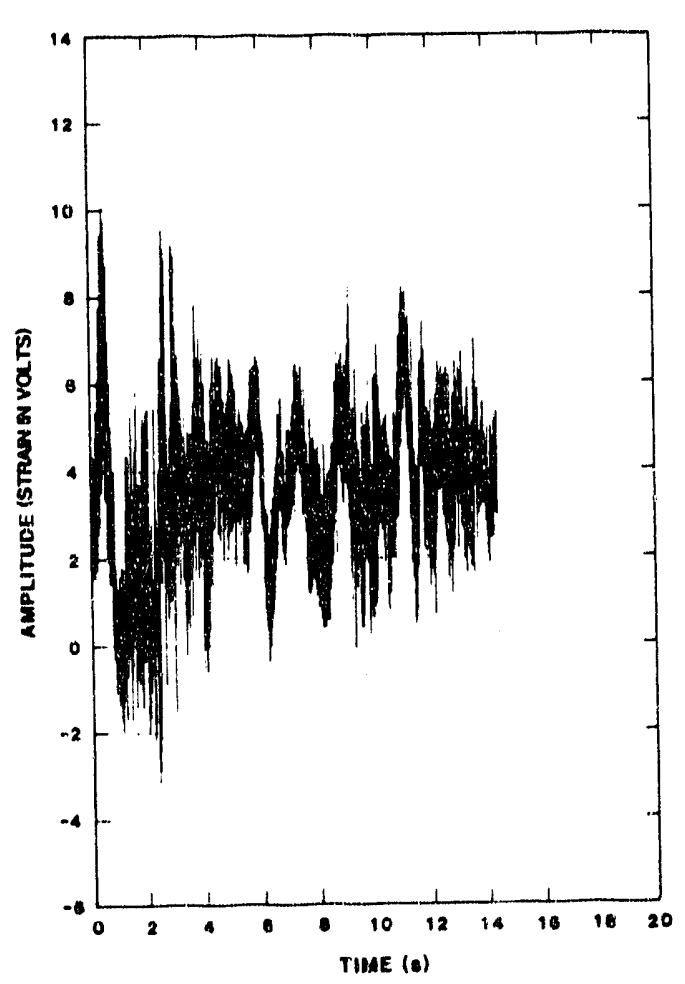

Figure B79 Road Test-CNS 3.55 Cask (Test 2) Front Strain Gaqe LoC. 113: Hard Stop

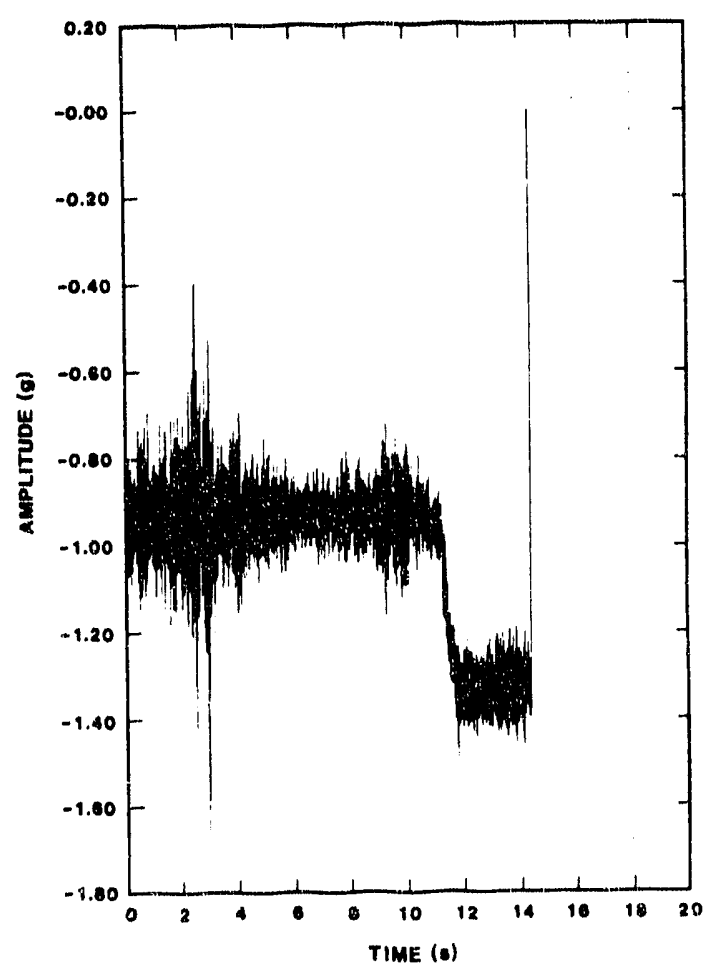

Figure B78. Road Test-CNS 3 55 Cask (Test 2) Rear Longitudinal Loc. \#6; Hard Stop

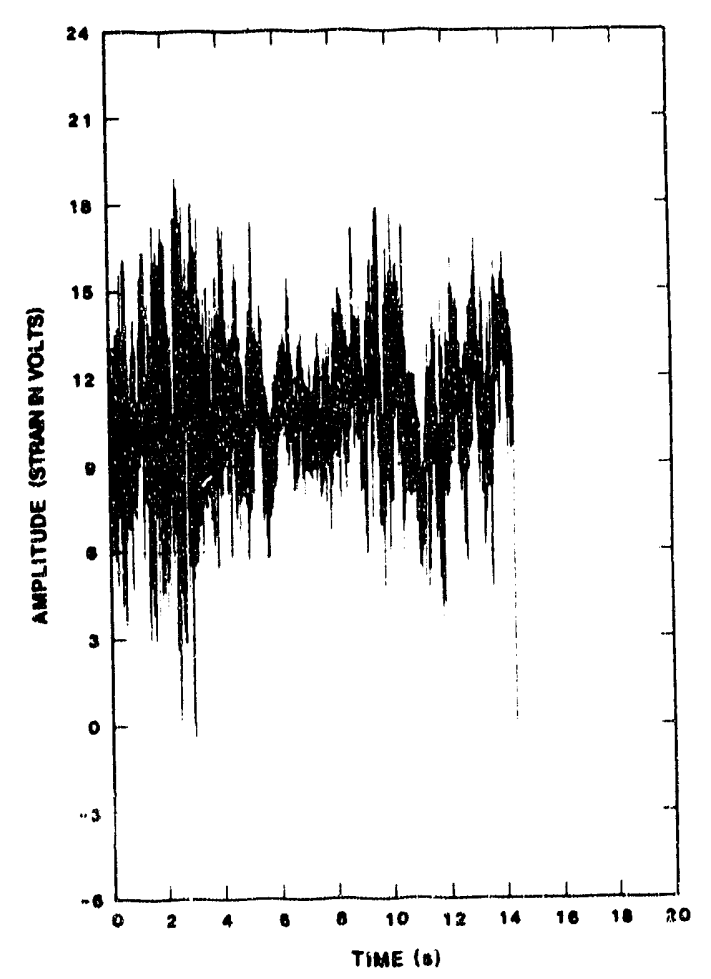

Figure B8O. R d Test-CNS 3-55 Cask (Test 2) Rcar Strain Gage Loc. 14: Hard Stop 


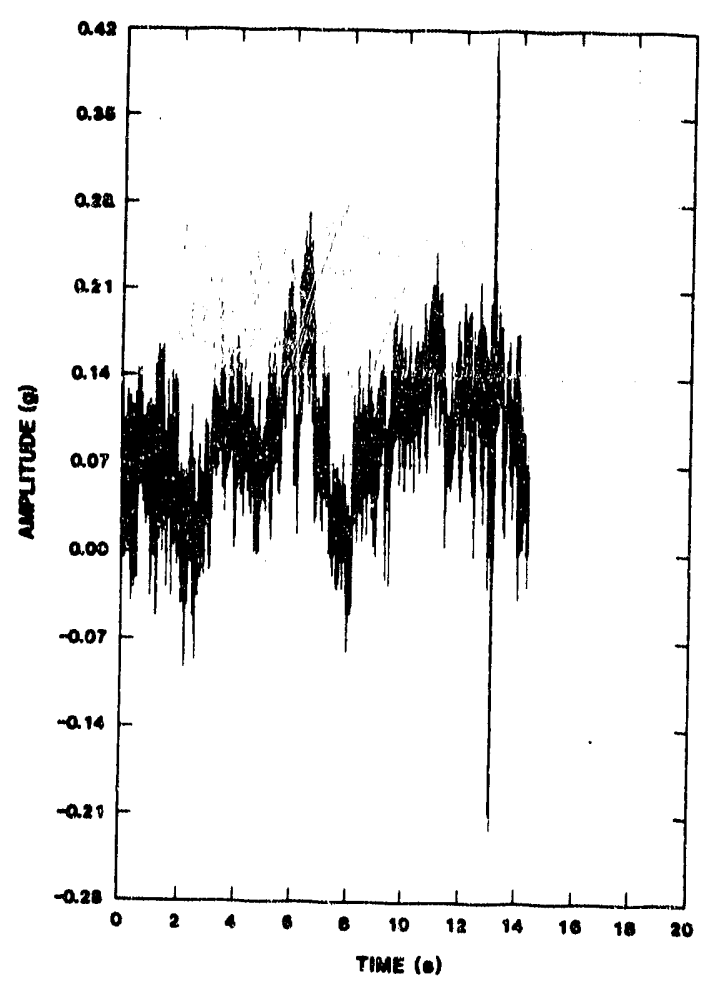

Figure B81, Road Test-CNS 3-55 Cask (Test 2) Top Transverse Loc. 1; Hough Secondary

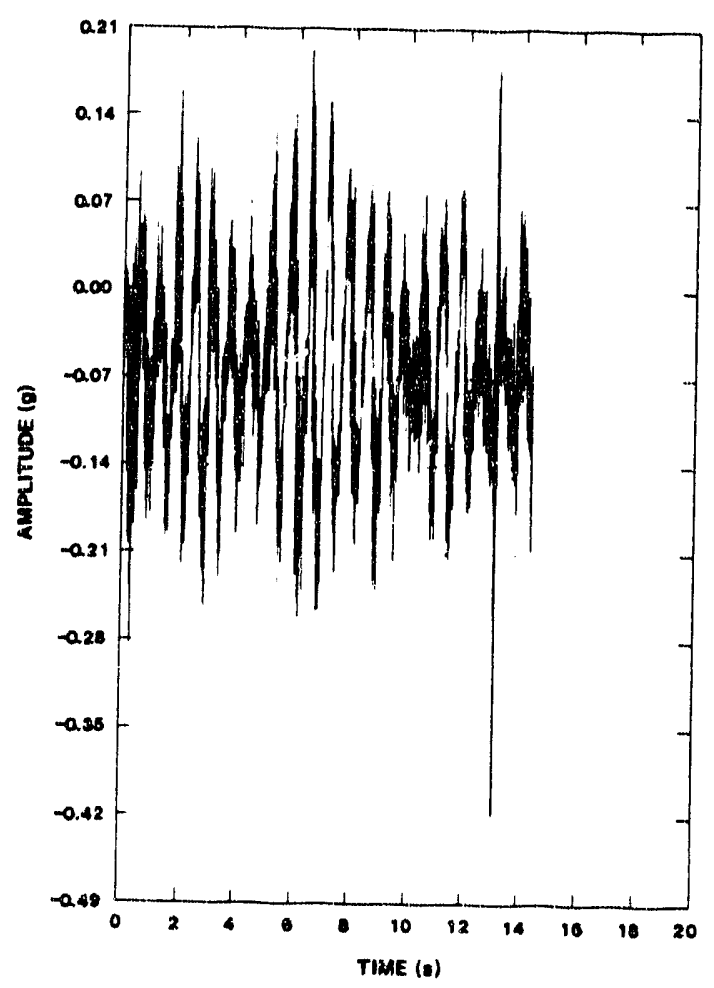

Figure B83. Road Test-CNS 3-55 Cask (Test 2) Top Vertical Loc. "2; Pough Secondary

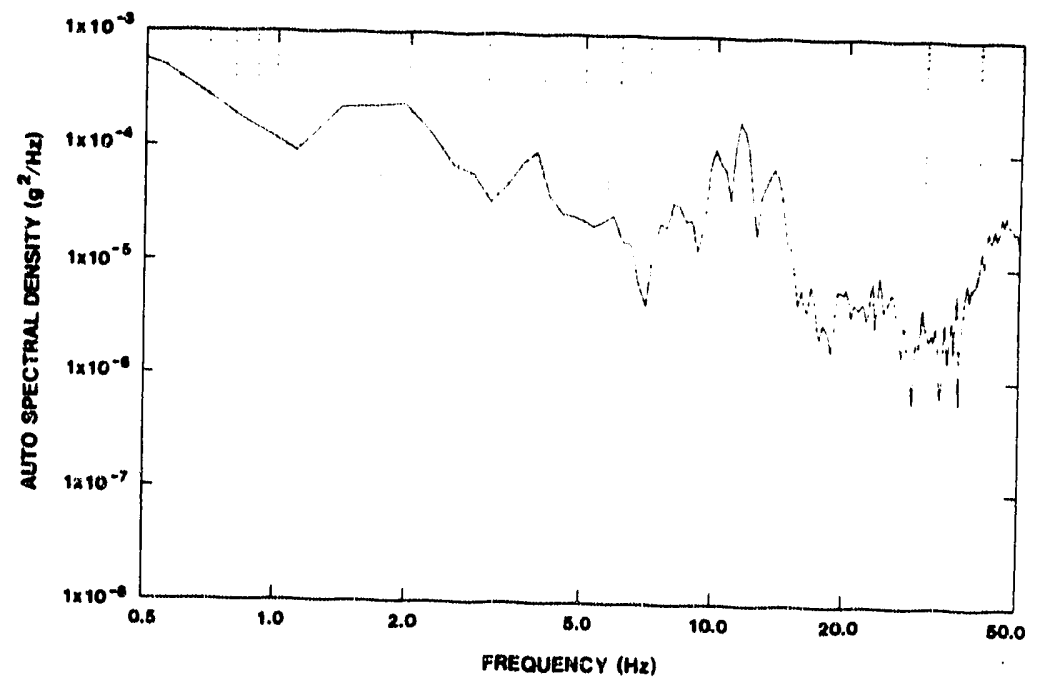

Figure B82. Road Test-CNS 3-55 Cask (Test 2)

Top Transverse Loc. \#1; Rough Secondary

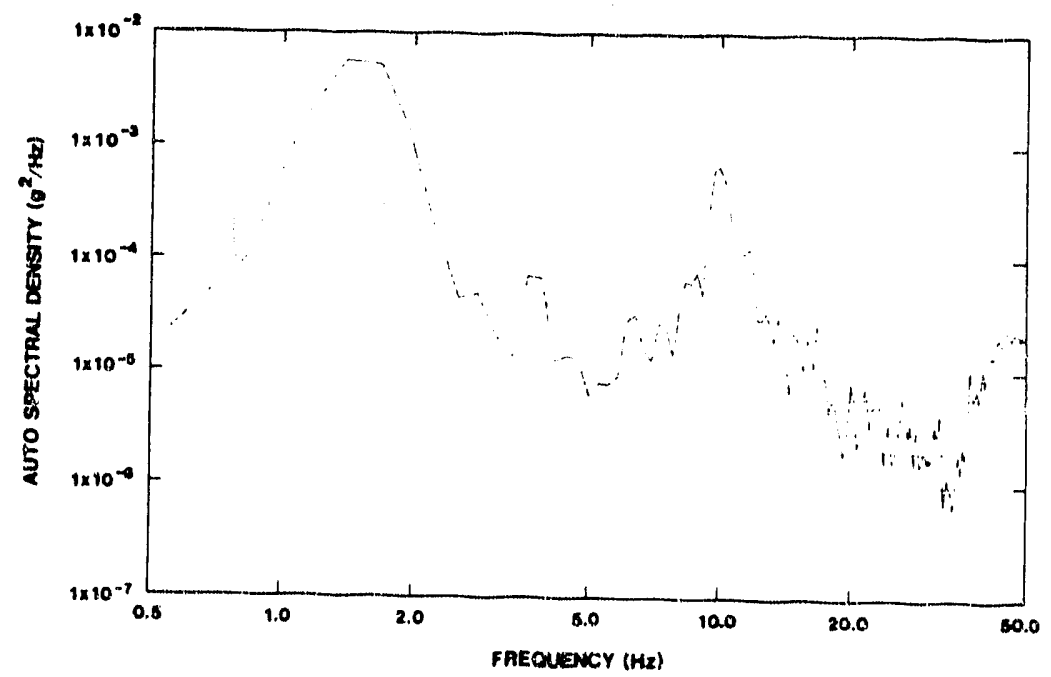

Figure B84. Road Test-CNS 3-55 Cask (Test 2) Top Vertical Loc. \#2; Rough Secondary 


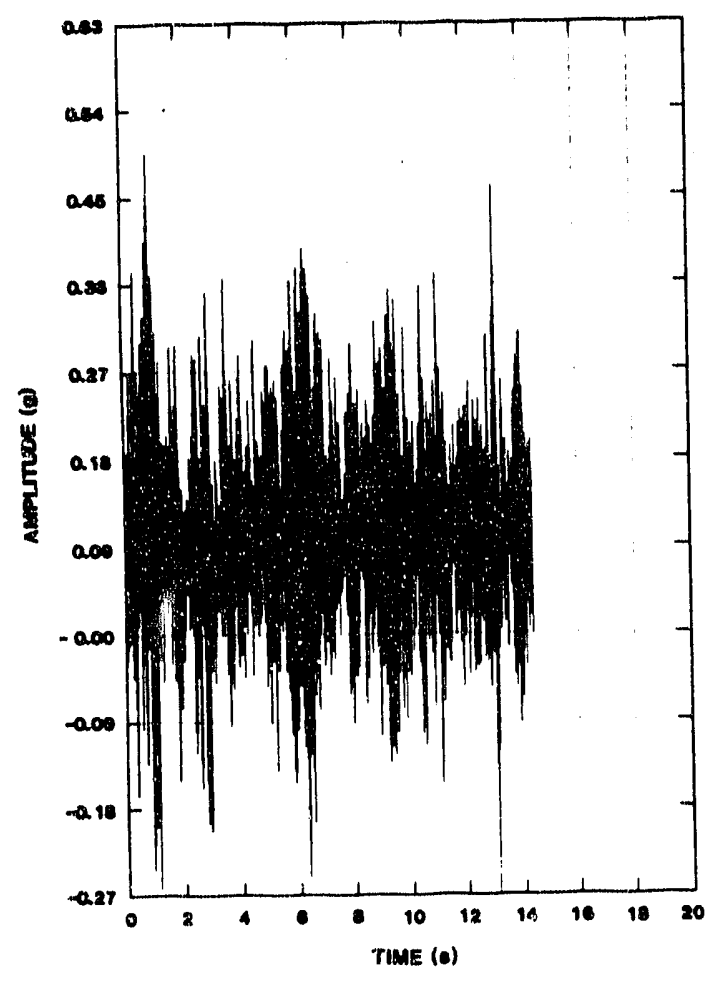

Figure B85. Foad Test-CNS 3-55 Cask (Test 2)

Top Longitudinal Loc. "3; Rough Secondary

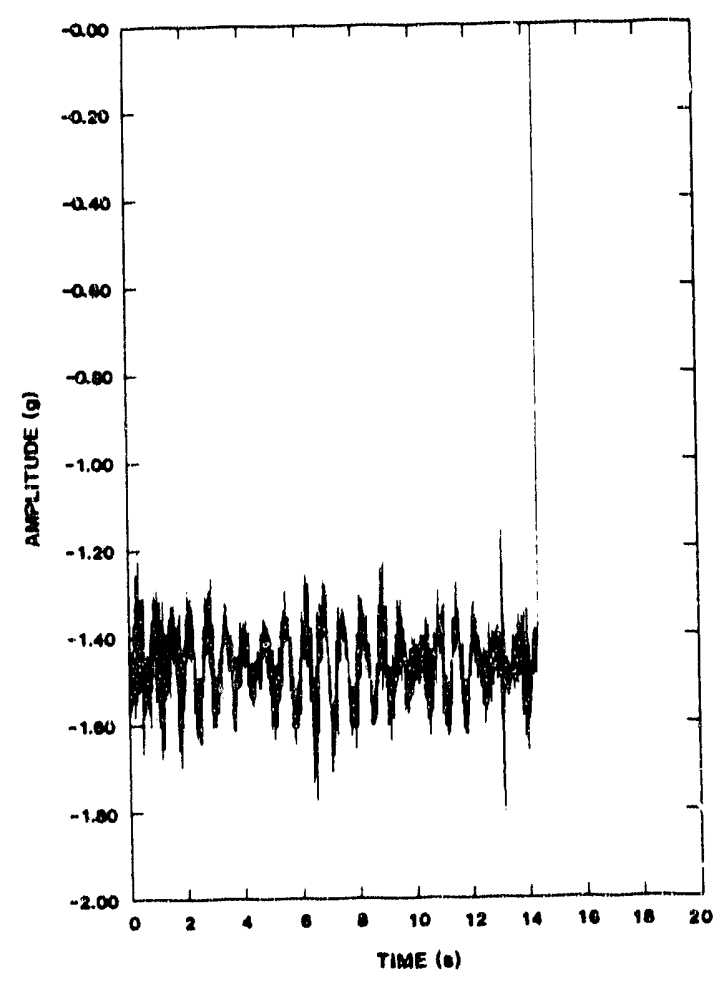

Figure B87. Road Test-CNS 3-55 Cask (Test 2) Mid Vertical Loc. 4; Rough Secondary

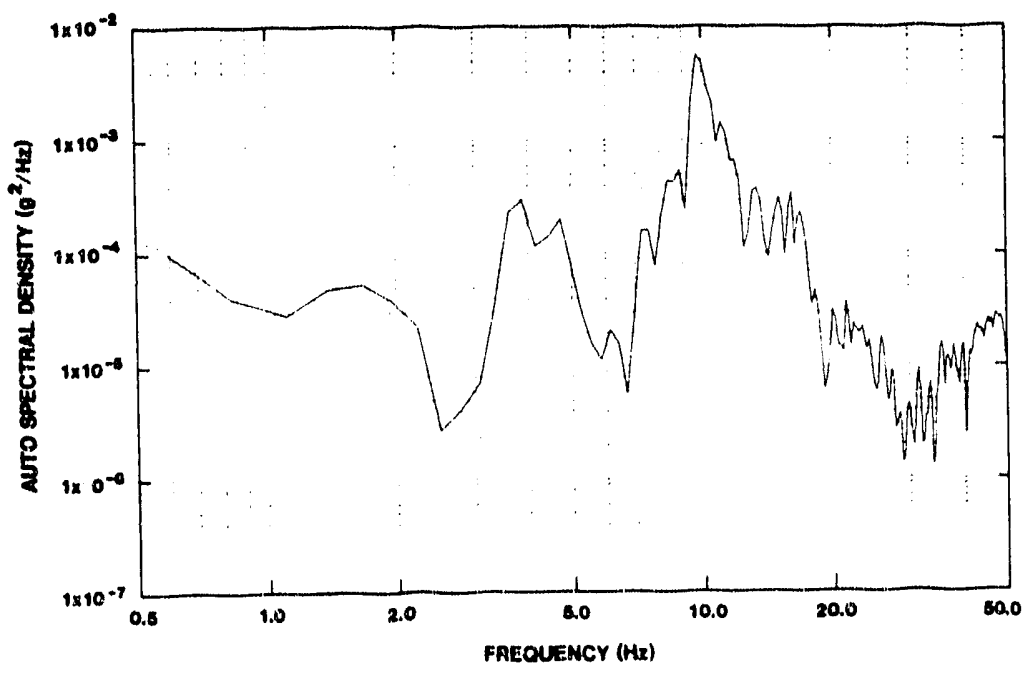

Figure B86. Road Tesi-CNS 3-55 Cask (Test 2) Top Longitudinal Loc. \#3; Rough Secondary

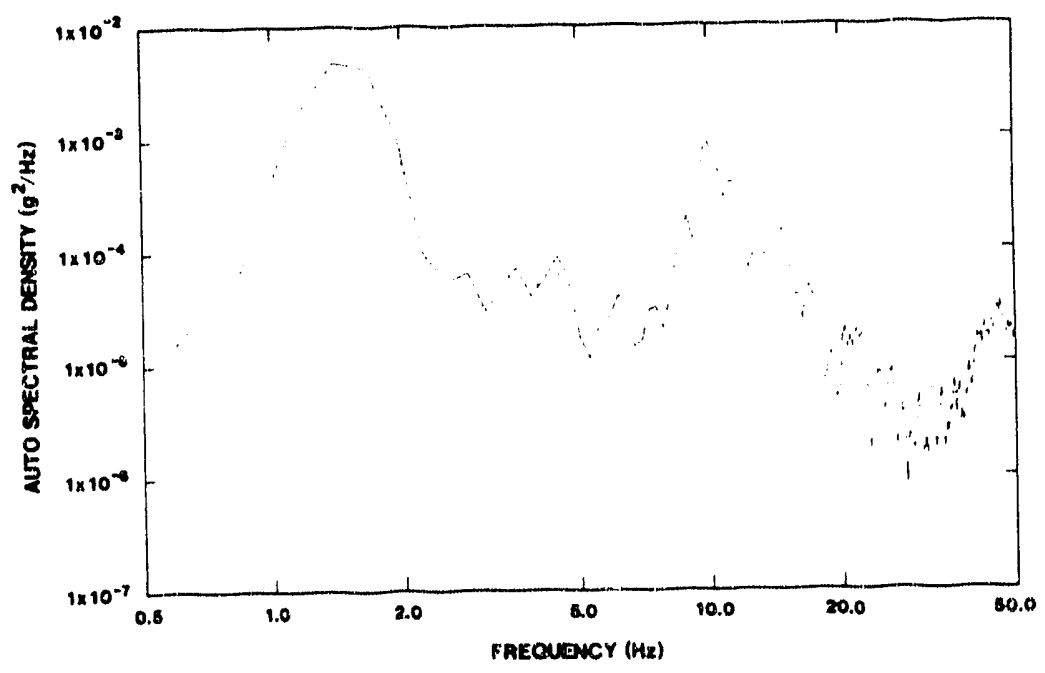

Figure B88. Road Test-CNS 3-55 Cask (Yost 2) Mid Vertical LOC. 4; Rough Secondary 


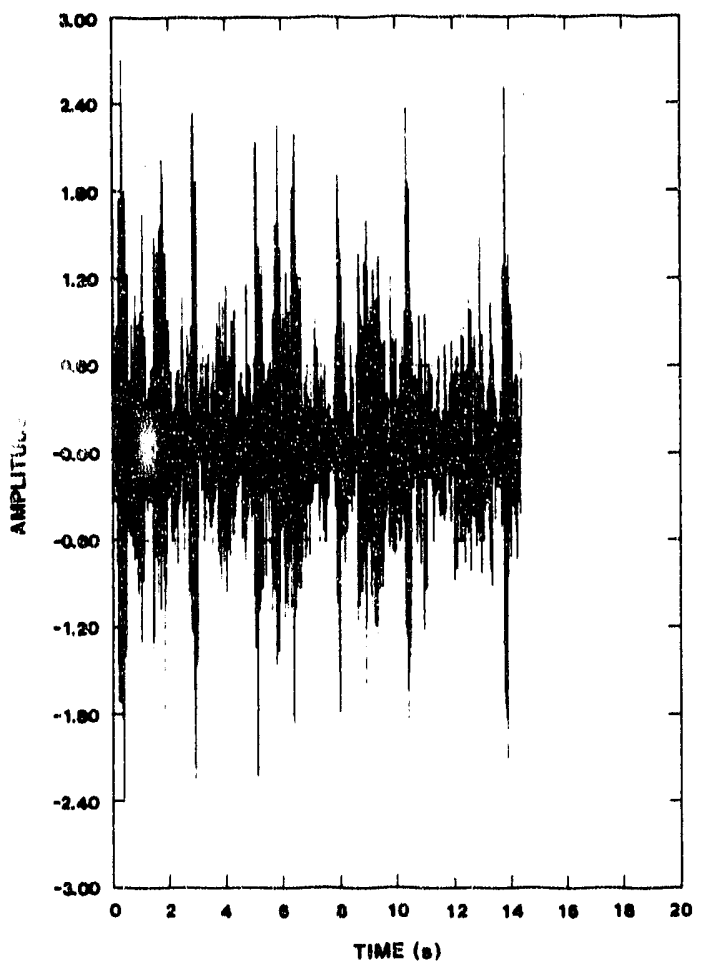

Figure 889. Road Test-CNS 3-55 Cask (Test 2) Rear Vertical Loc. \#5; Rough Secondary

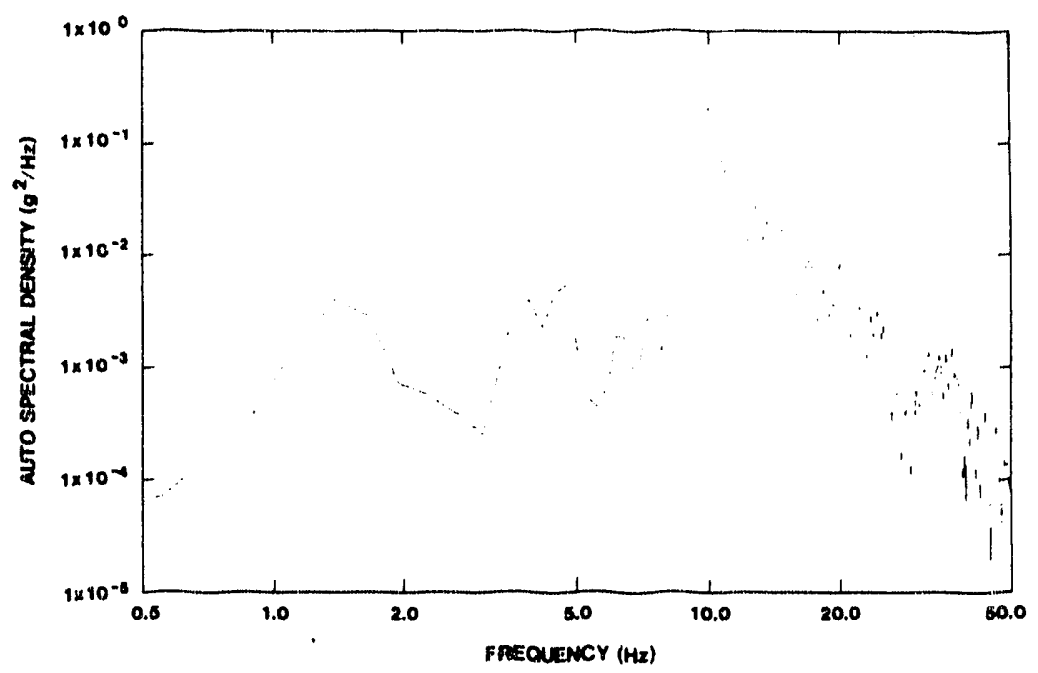

Figuru 890. Road Test-CNS 3-55 Cask (Test 2) Rear Vertical Loc. \#5; Rough Secondary 


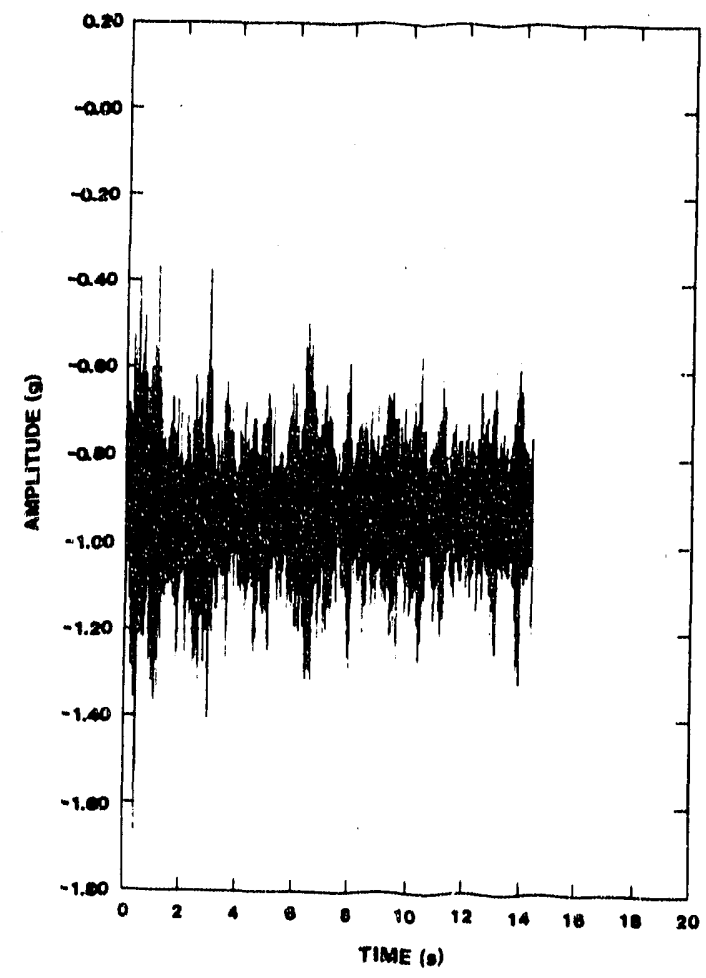

Figure B91. Hoad Test-CNS 3-55 Cask (Test 2) Rear Longitudinal Loc. "66; Rough Secondary

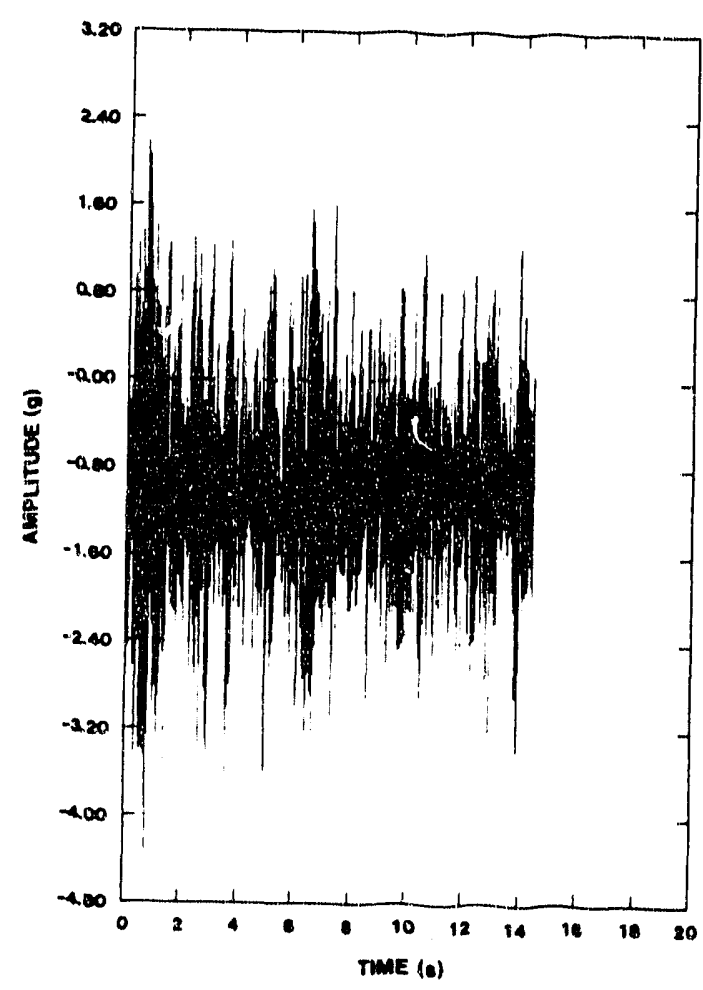

Figure B93. Road Test-CNS 3-55 Cask (Test 2) Front Vertical l.oc. 17; Rough Secondary

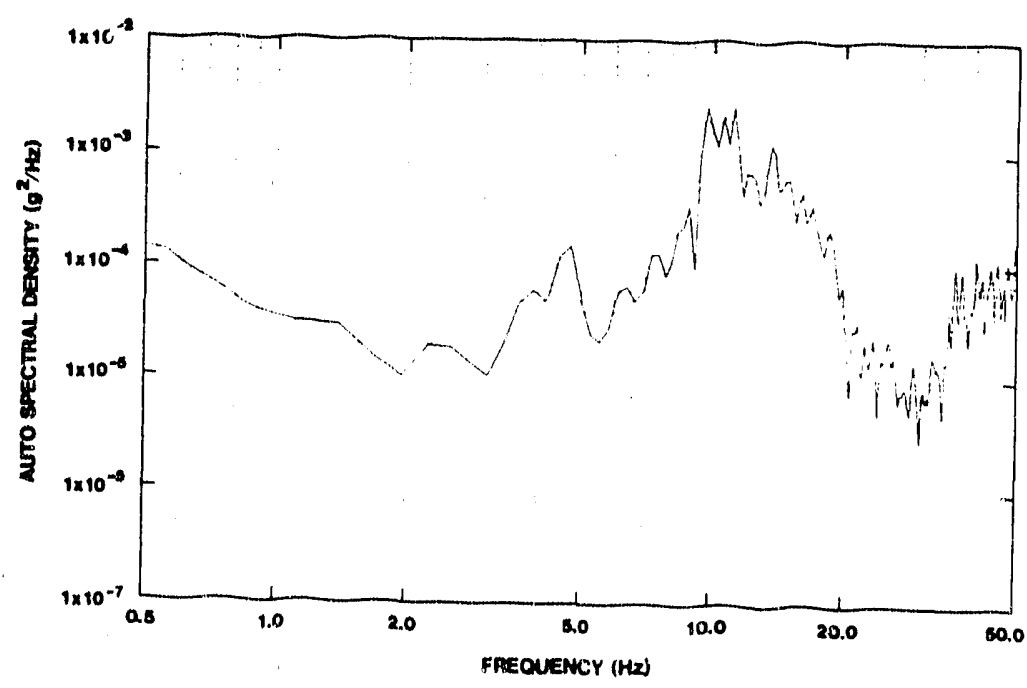

Figure B92. Road Test-CNS 3-55 Cask (Test 2) Rear Longitudinal Loc. \#6; Aough Secondary

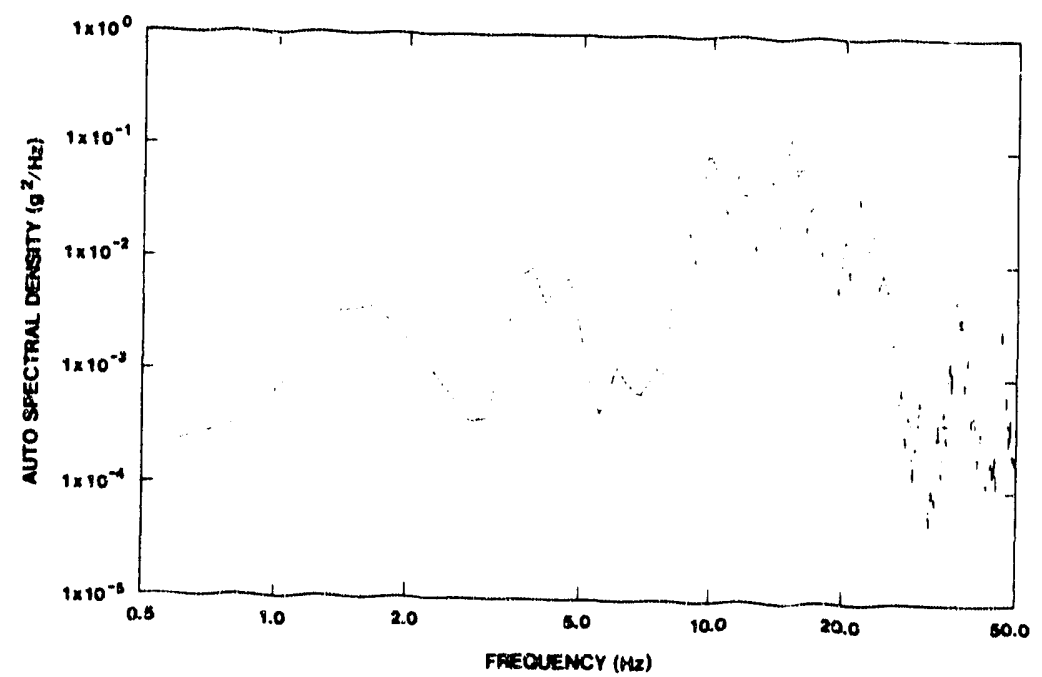

Figure B94. Road Test.CNS 3-55 Cask (Test 2) Front Vertical Loc. "7; Rough Secondery 


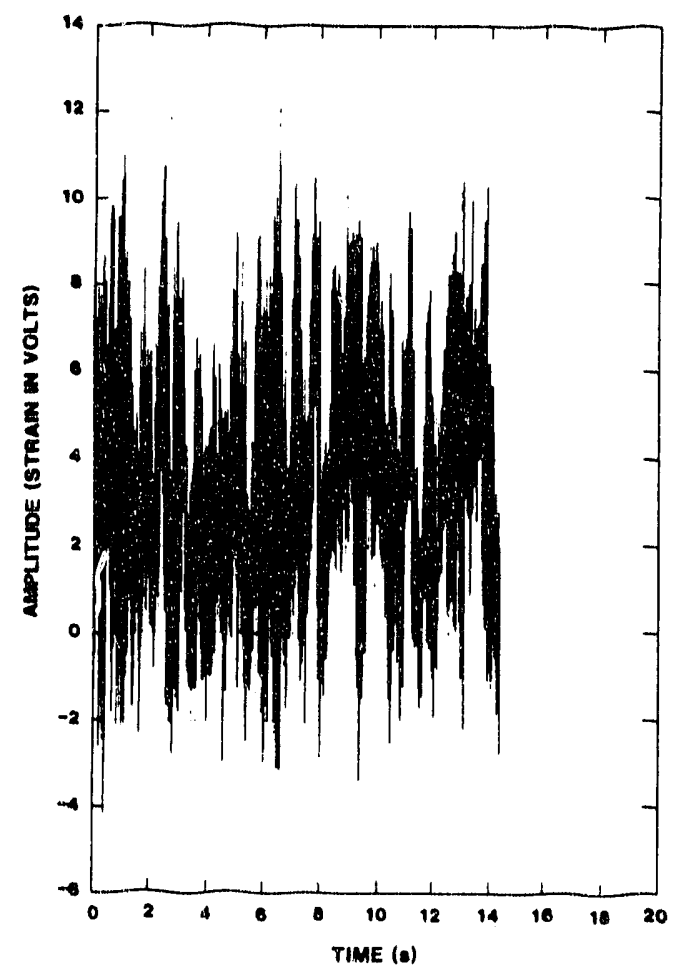

Figure B95. Road Test-CNS 3-55 Cask (Test 2) Front Strain Gage Loc. 13; Rough Secondary

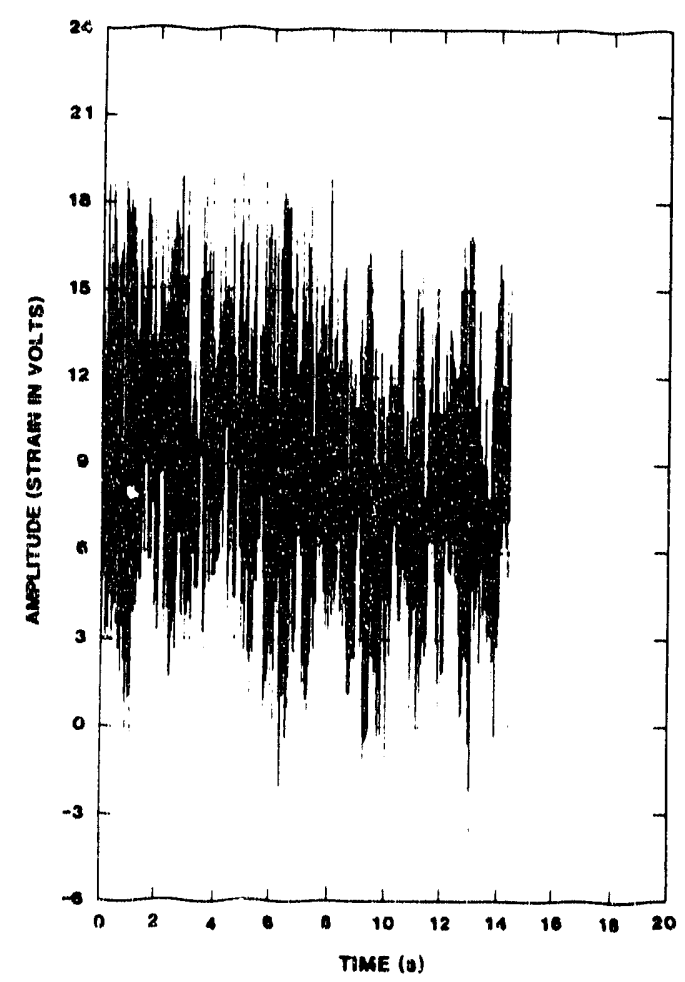

Figure 897. Road Test-CNS 3-55 Cask (Test 2) Aear Strain Gage LOC. 14: Rrugh Secondary

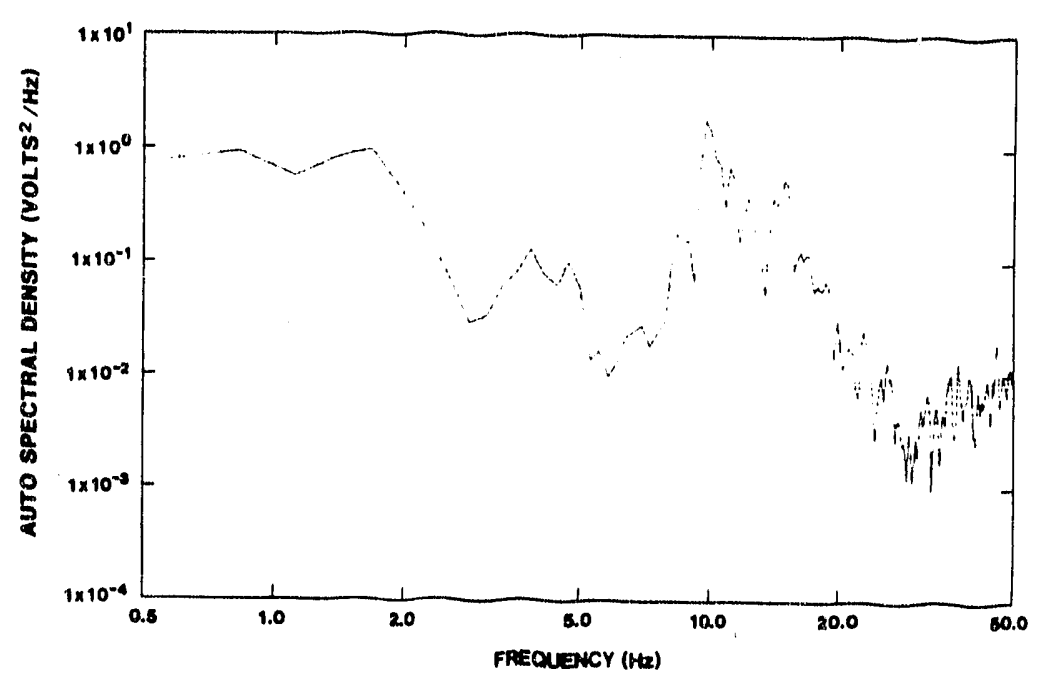

Figure B96. Road Test-CNS 3-55 Cask' (Test 2) Front Strain Gage Loc. \#13; Rough Secondary

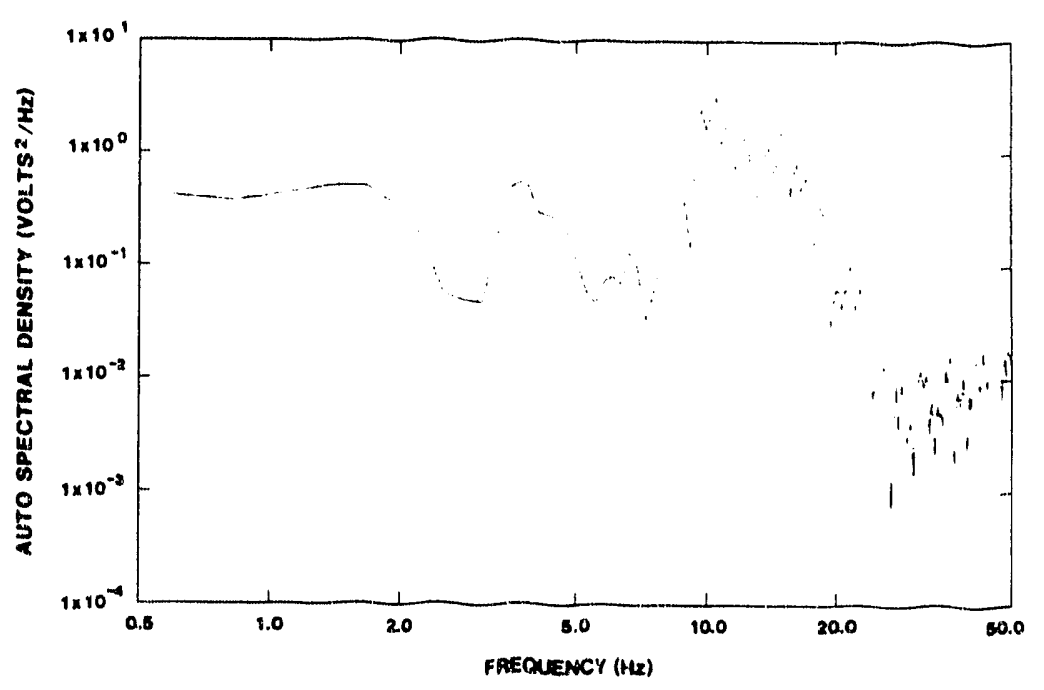

Figure 898. Road Test-CNS 3-55 Cask (Test 2) Rear Strain Gage Loc. 14: Rough Secondary 


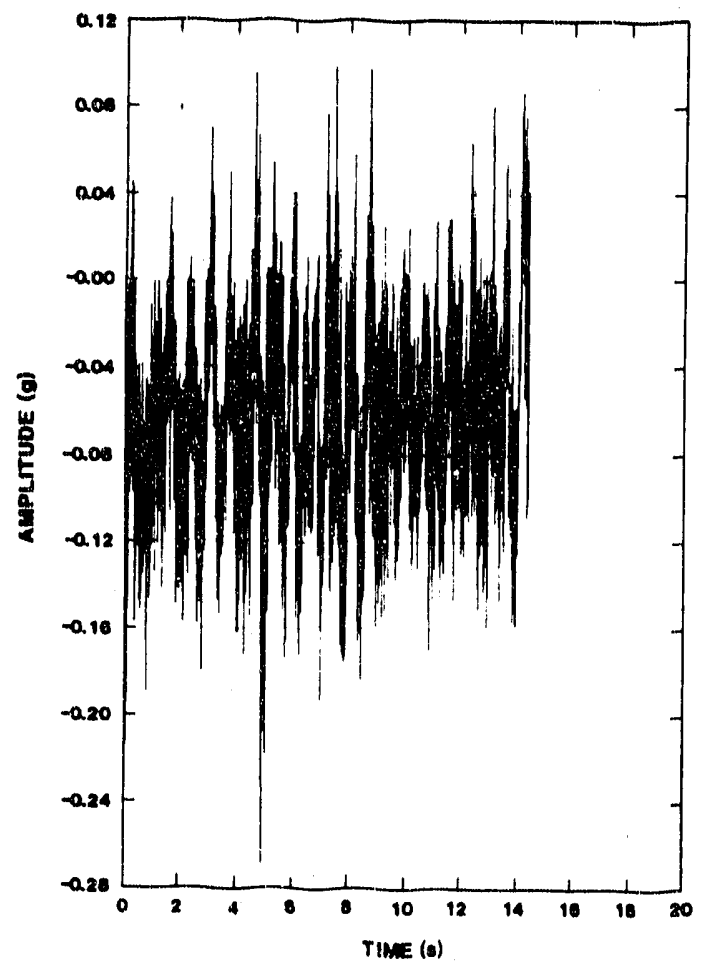

Figure B99. Road Test-CNS 3-55 Cask (Test 2) Top Vertical Loc. \#2; Spalled Asphalt

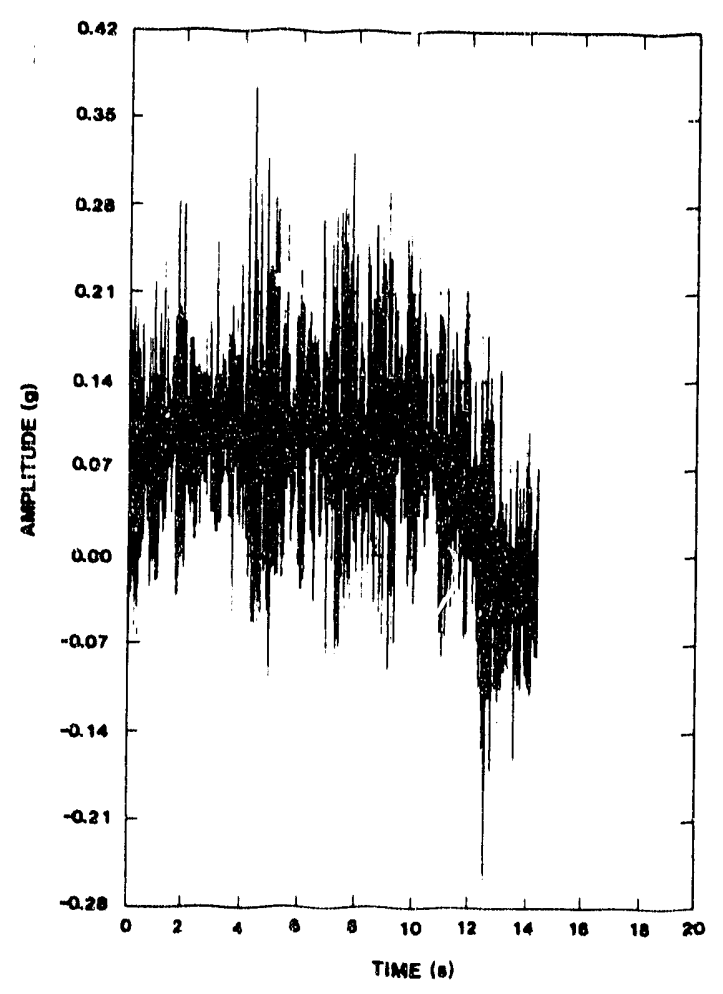

Figure B101. Road Test-CNS 3-55 Cask (Test 2) Top Longitudinal Loc. \#3, Spalted Asphalt

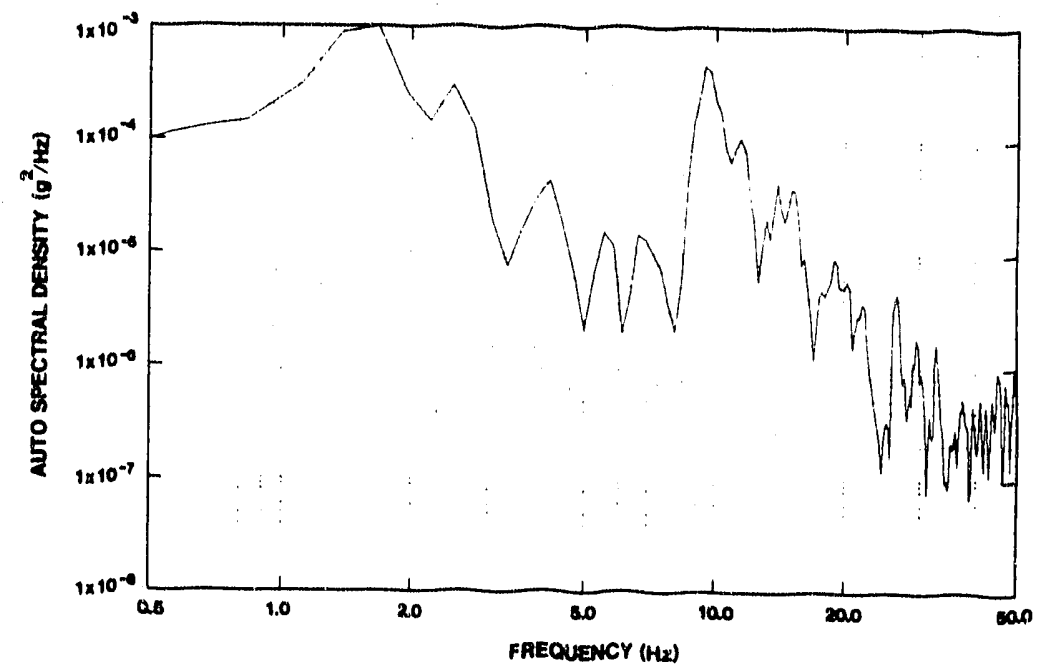

Figure B100. Foad Test-CNS 3-55 Cask (Test 2) Top Vertical Loc. \#2; Spalled Asphalt

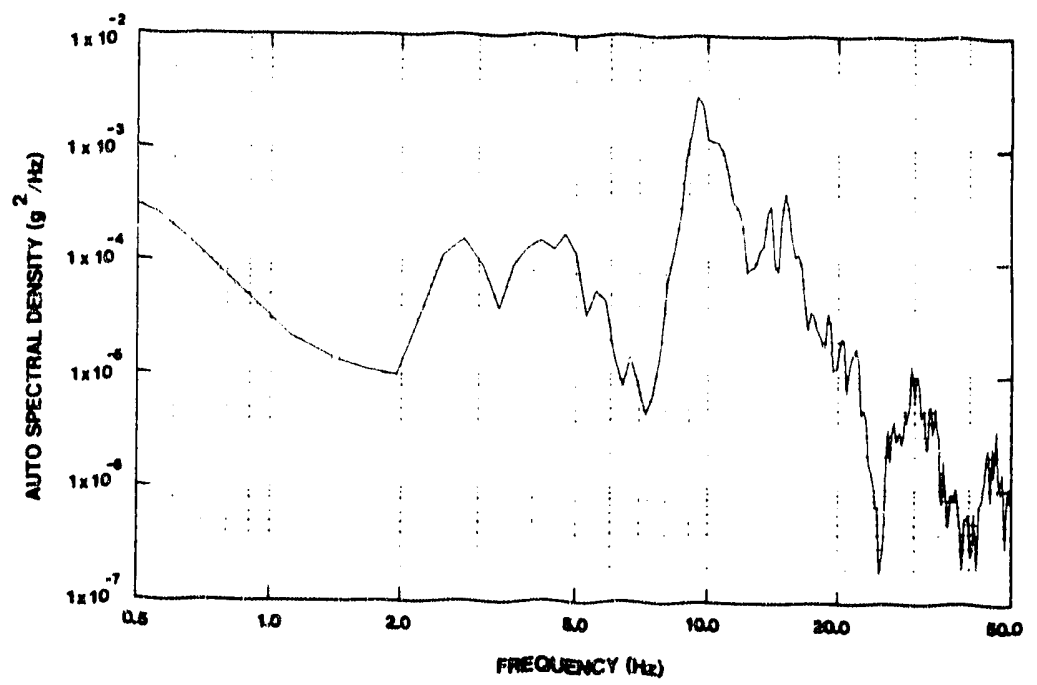

Figure B102. Road Test-C.NS 3-55 Cask (Test 2) Top Longitudinal Loc. *3; Spalled Asphalt 


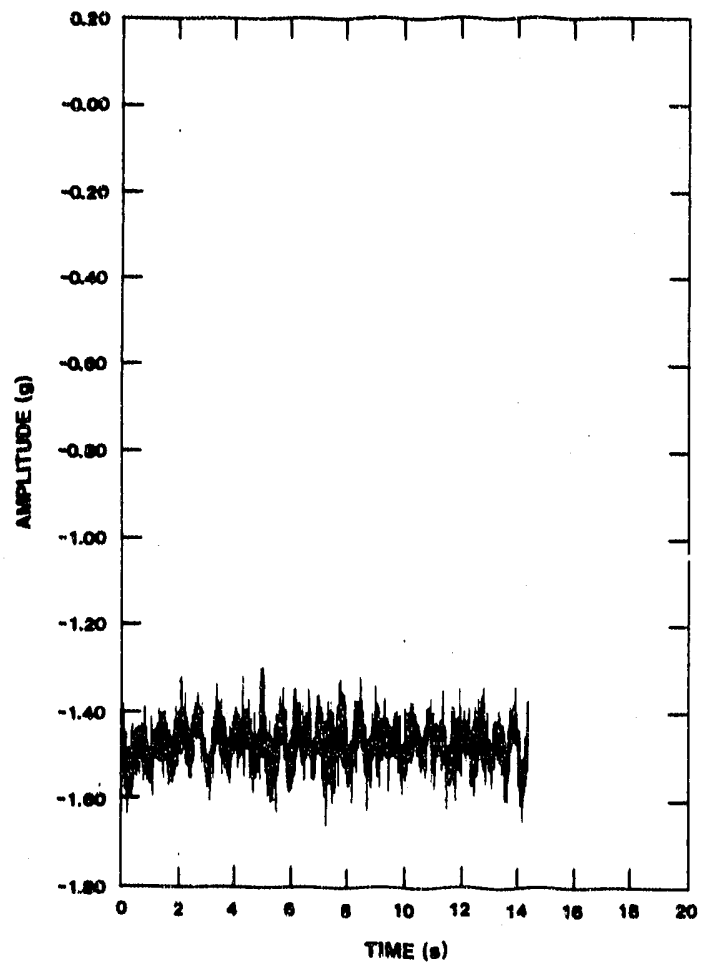

Figure B103. Road Test-CNS 3-55 Cask (Test 2) Mid Vertical Loc. "4; Spalled Asphalt

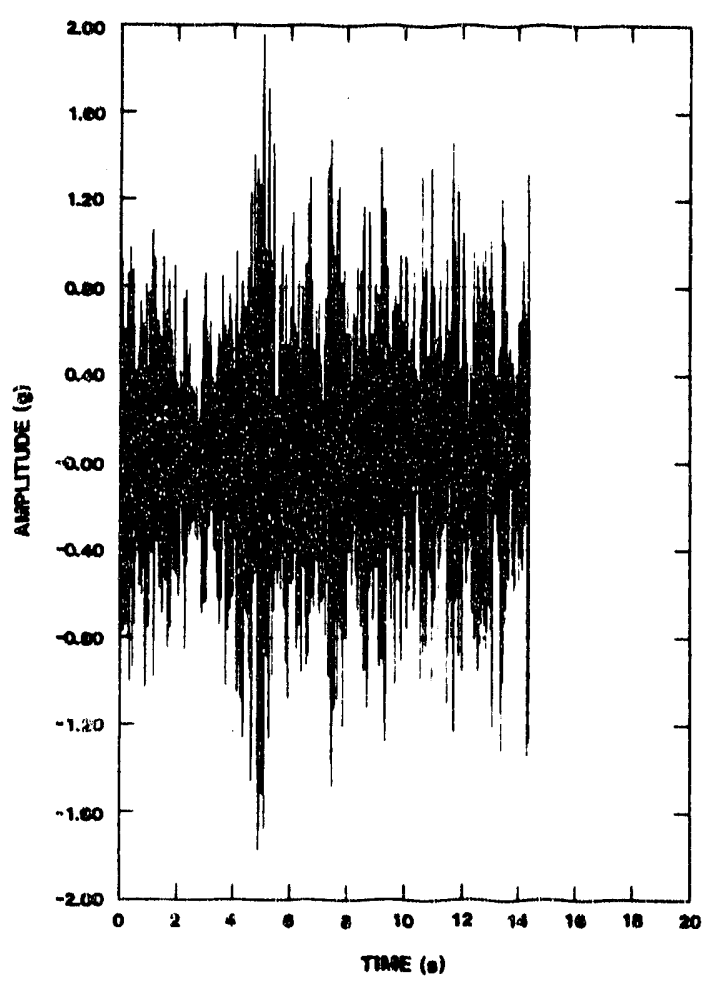

Figure 8105. Road Test-CNS 3-55 Cask (Tesi 2) Rear Vertical LOC $\# 5$; Spalled Asphalt

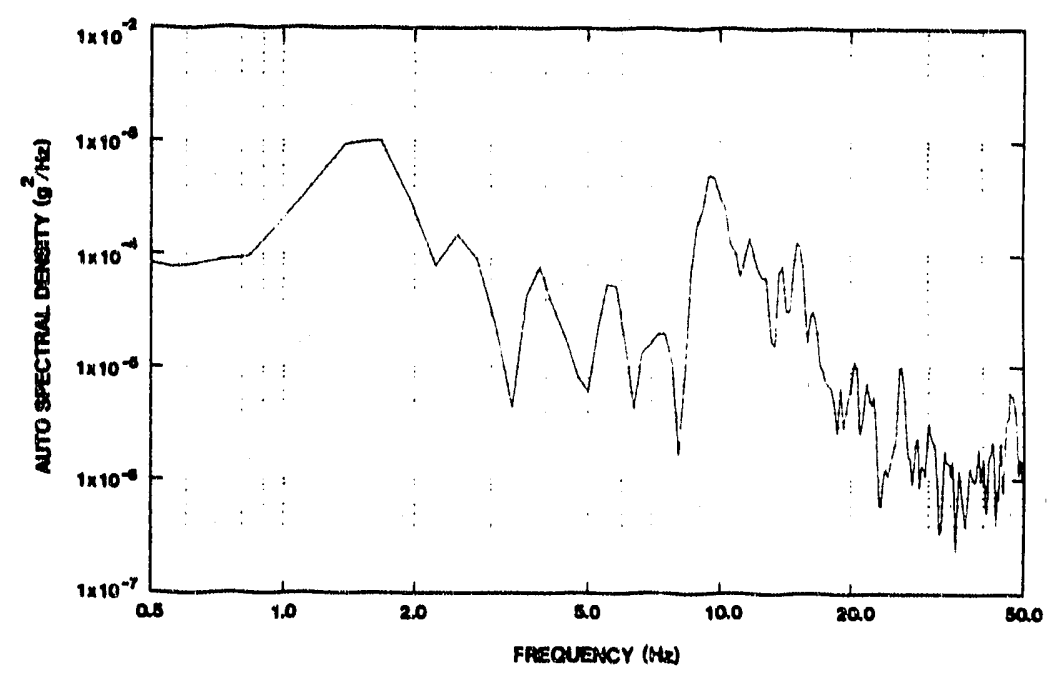

Figure B104. Road Test-CNS 3-55 Cask (Test 2) Mid Vertical Loc. \#4; Spalled Asphals

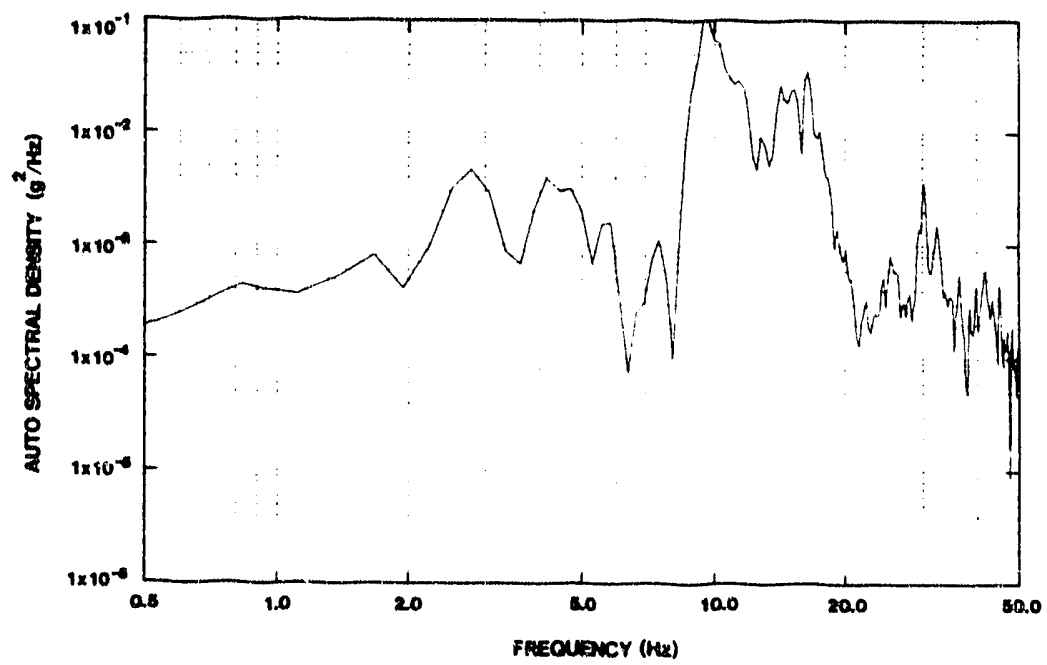

Figure B 106. Road Test-CNS 3-55 Cask (Test 2) Rear Verticai Loc. 15: Spalled Asphalt 


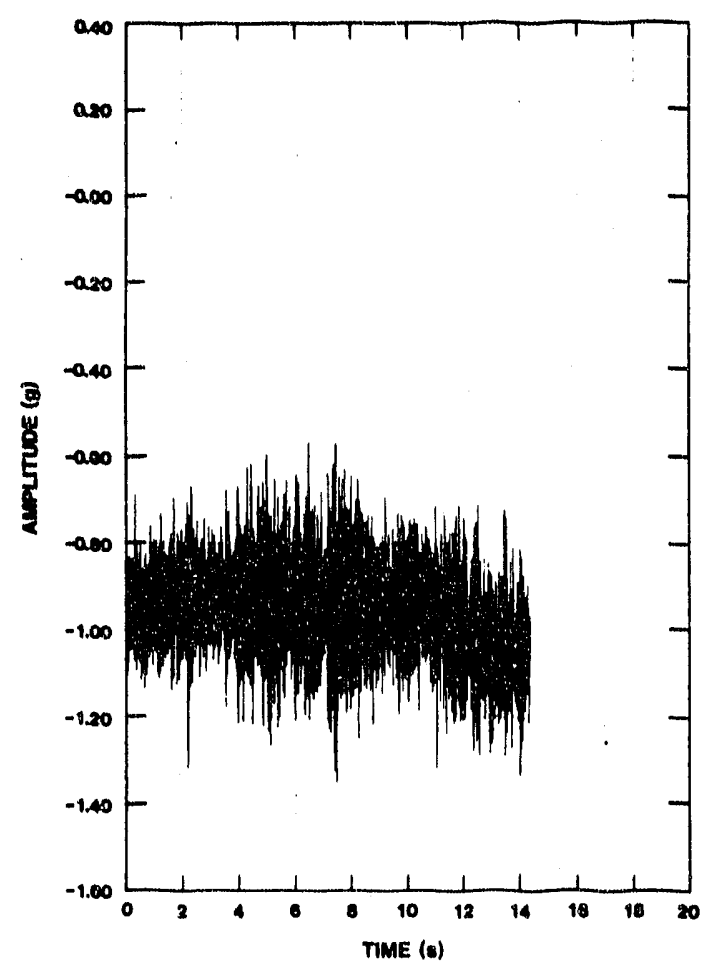

Figure B107. Road Test-CNS 3-55 Cask (Test 2) Rear Longltudinal Loc. "6; Spalled Asphalt

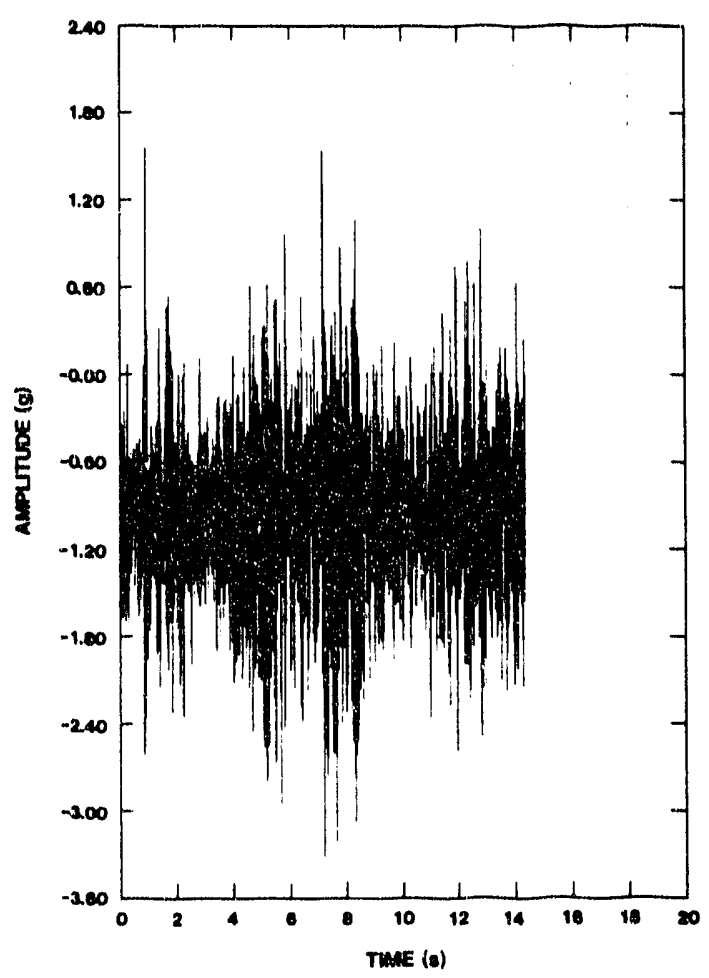

Figure B109. Road Test-CNS 3-55 Cask (Test 2) Front Vertical Loc. \#7; Spalled Asphalt

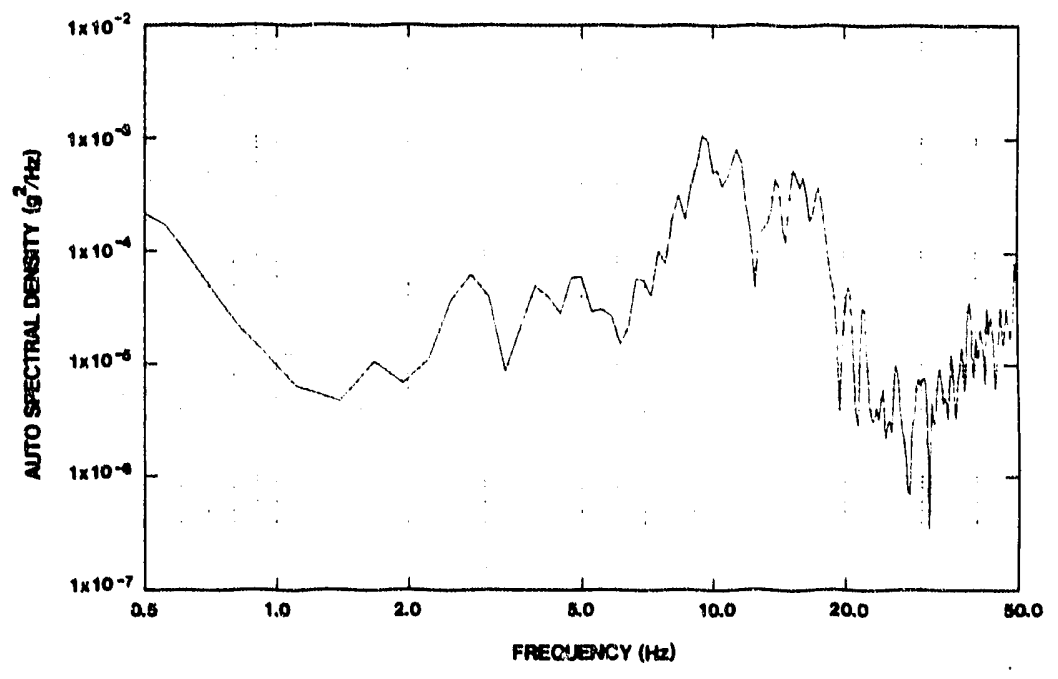

Figure B108. Road Test-CNS 3-55 Cask (Test 2)

Rear Longitudinal Loc. "6; Spalled Asphalt

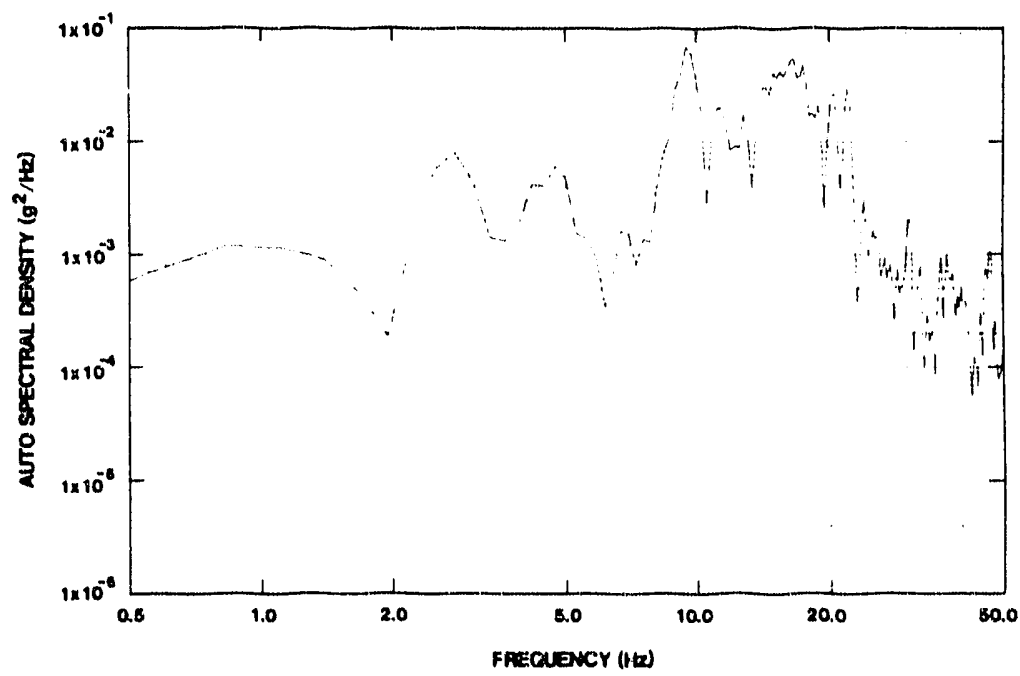

Figure B110. Road Test-CNS 3-55 Cask (Test 2) Front Vertical Loc. H7; Spalled Asphait 


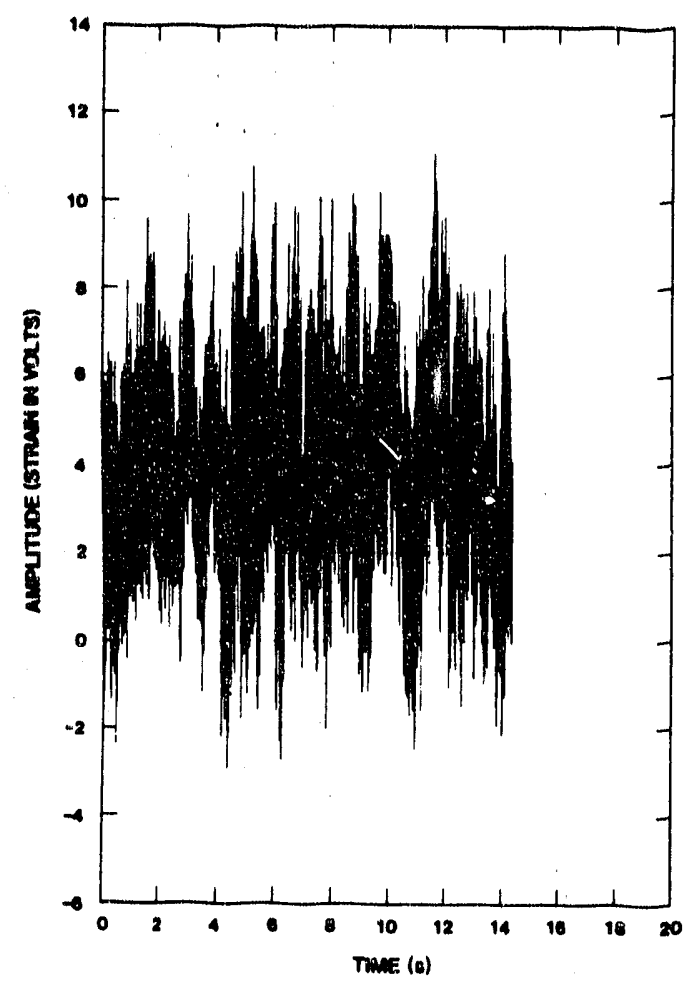

Figure B111. Foad Test-CNS 3-55 Cask (Tes! 2) Front Strain Gage Loc. \#13; Spallen Asphalt

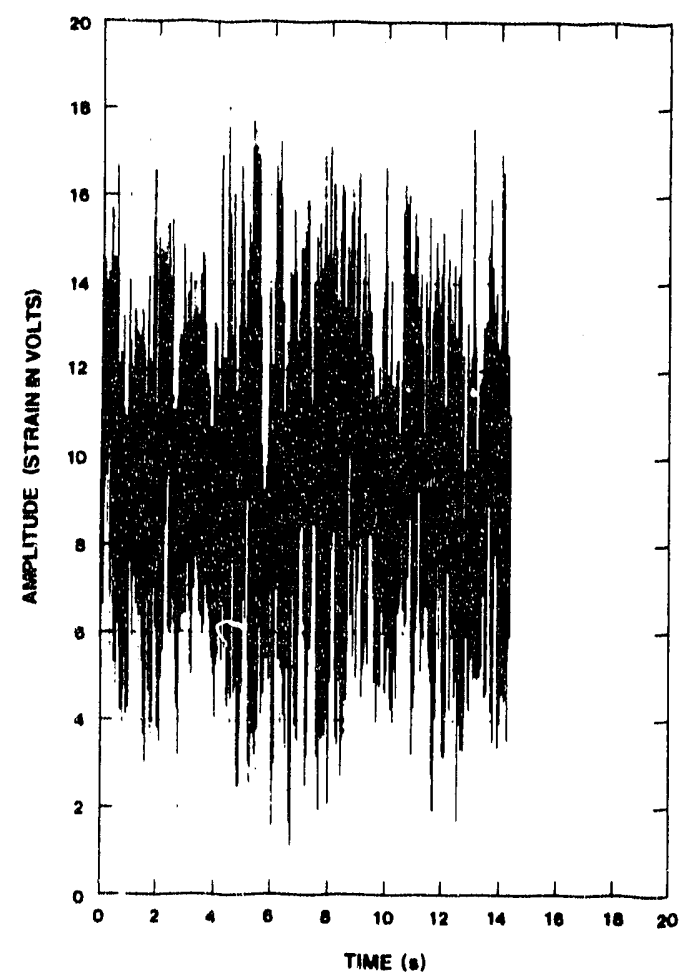

Figure 8113. Road Test-CNS 3-55 Cask (Test 2) Rear Strain Gage LOC. 14, Spalled Asphalt

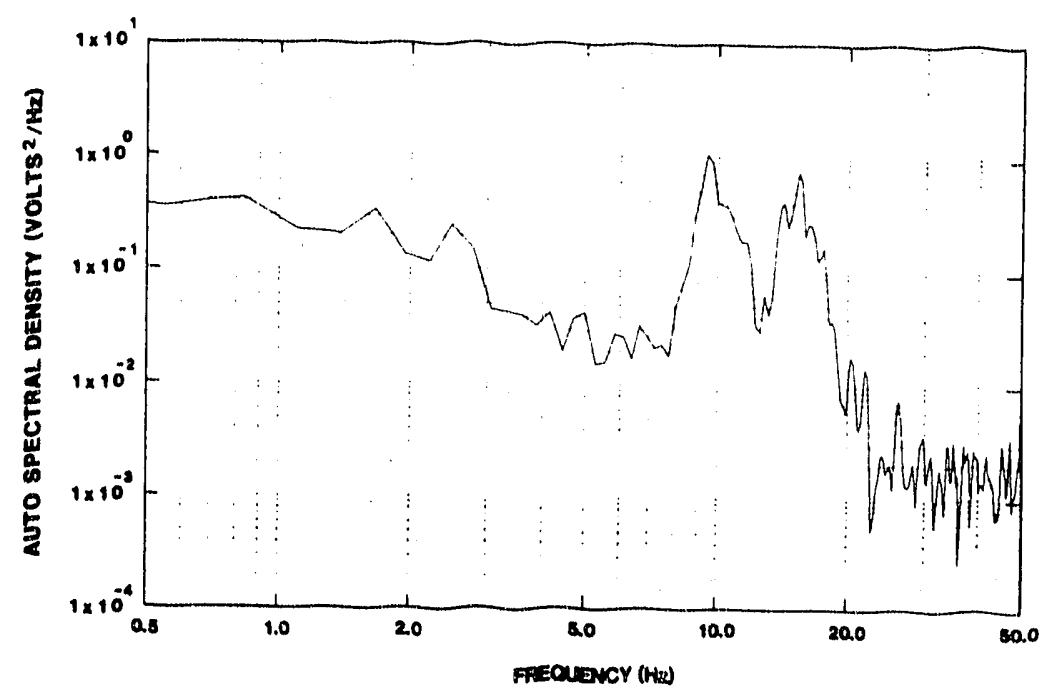

Figure B112. Road Test-CNS 3-55 Cask (Test 2) Front Strain Gage Loc. \#13; Spalled Asphalt

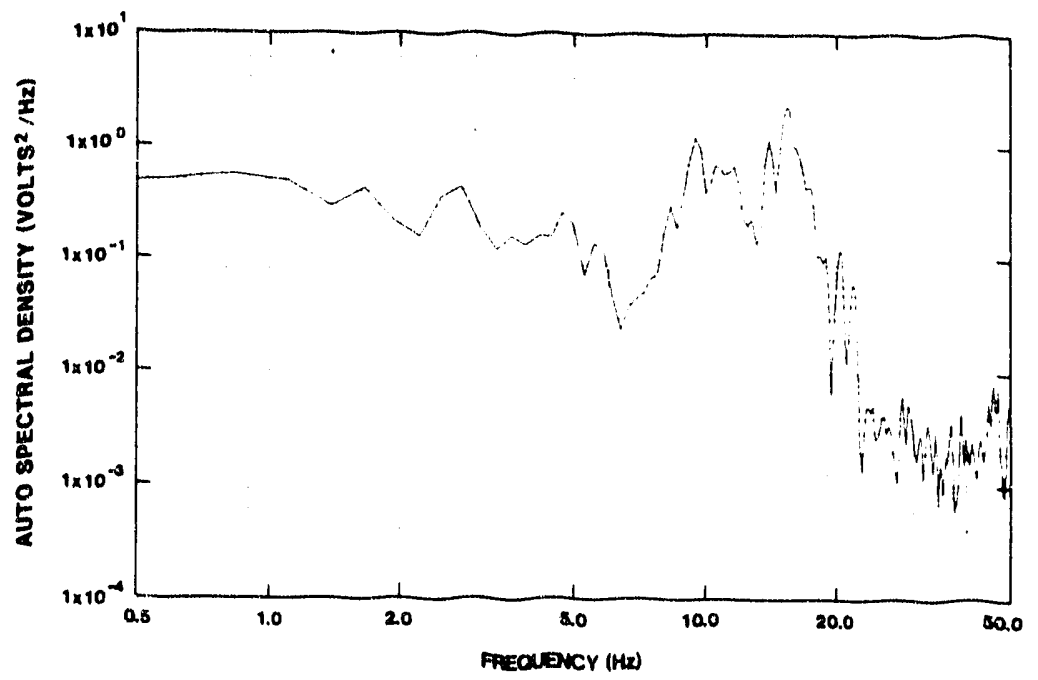

Figure B114. Road Test-CNS 3-55 Cask (Test 2)

Rear Strain Gage Loc. 14; Spalled Asphait 


\section{External D1stribution:}

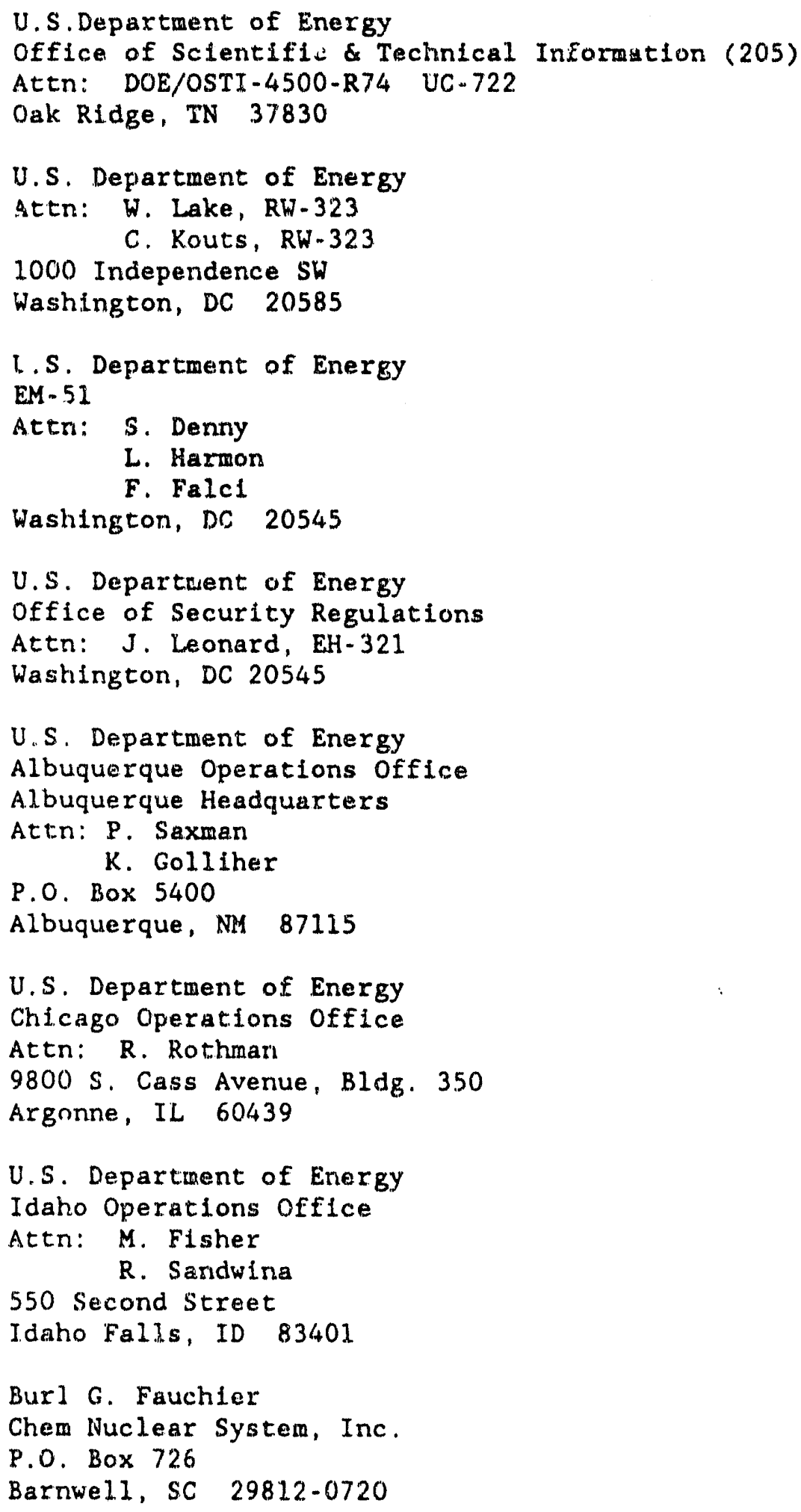




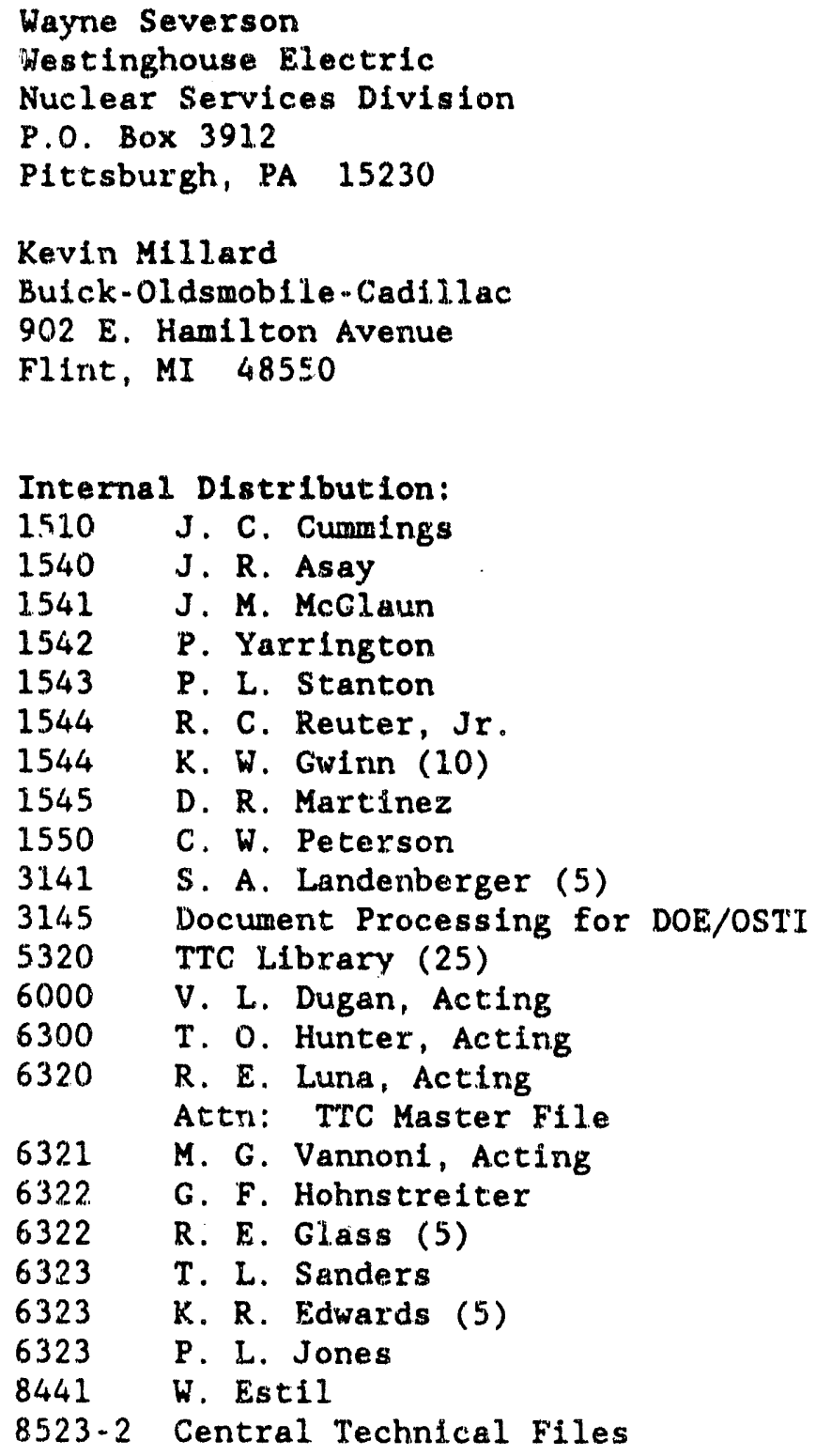



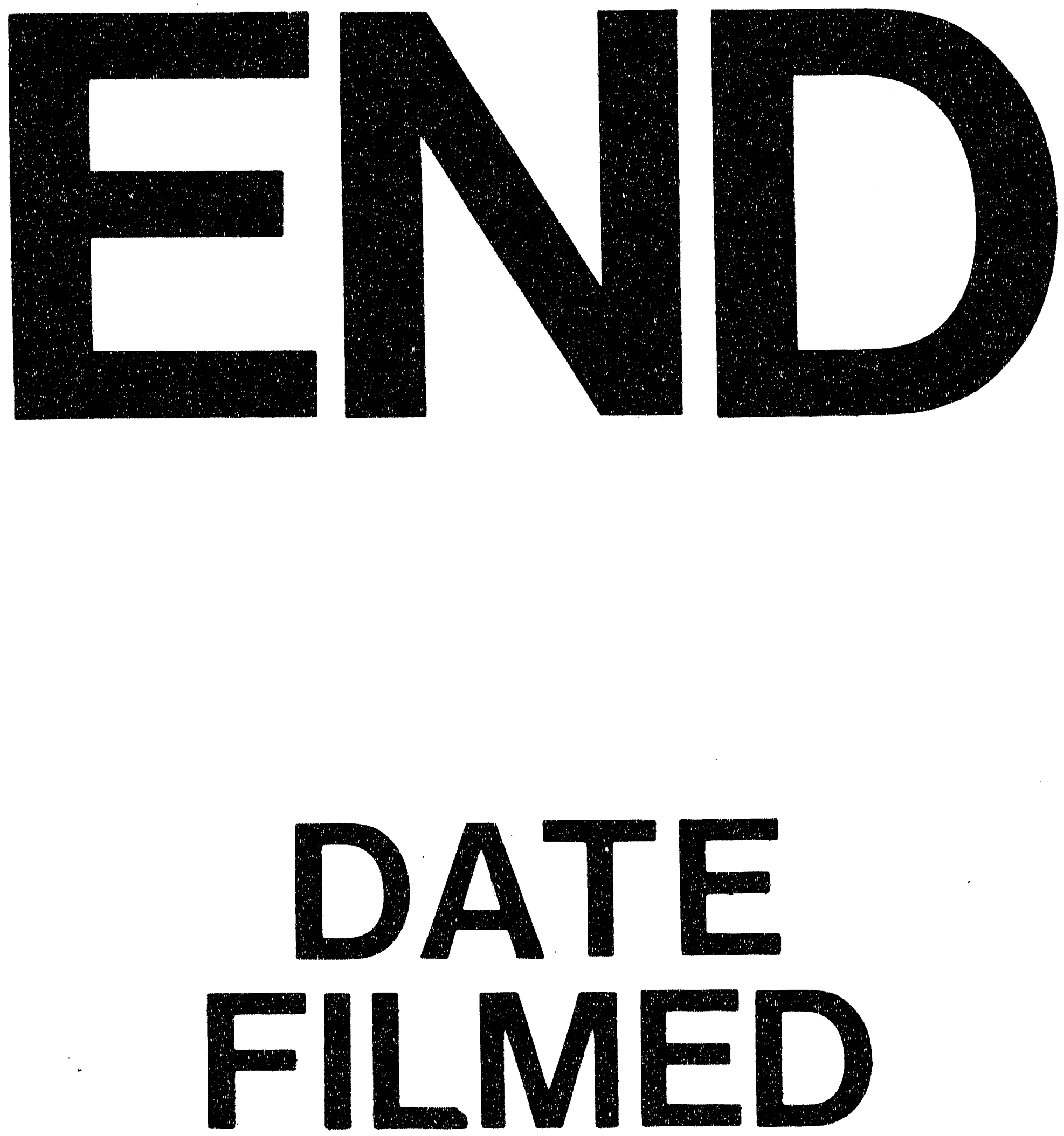

$I$

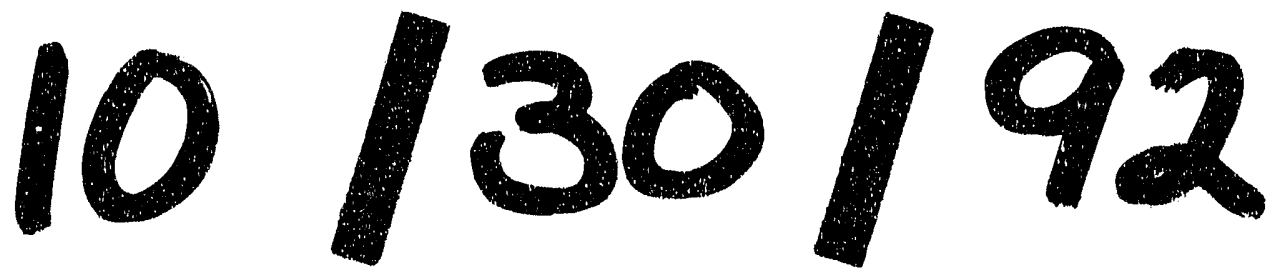


